



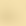





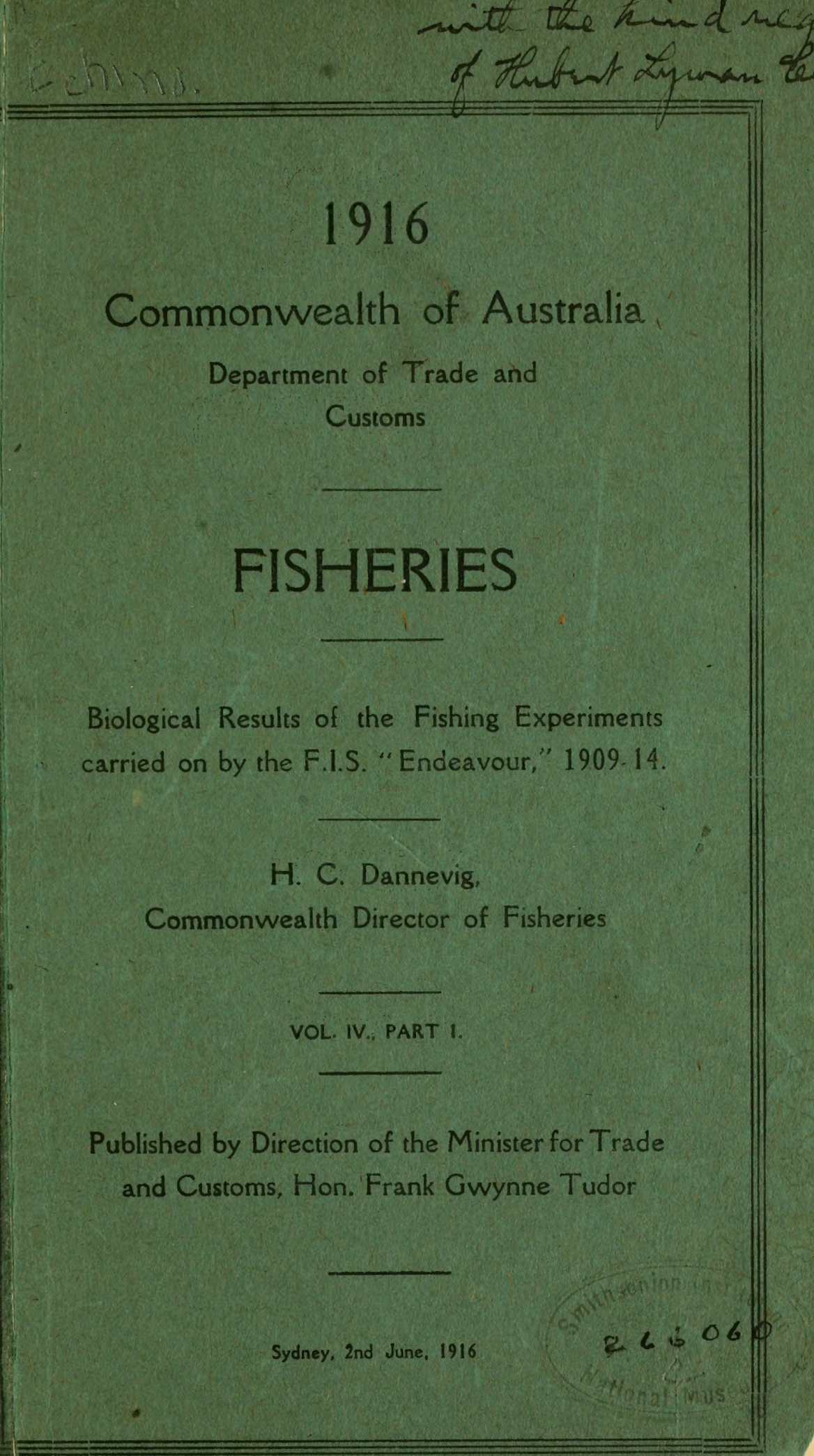



1. Report on the Sea-Lilies, Starfishes, Brittle-Stars and Sea-Urchins obtained by the F.I.S. "Endeavour" on the coasts of Queensland, New South Wales, Tasmania, Victoria, South Australia, and Western Australia.

BY

HUBERT LYMAN CLARK,

Curator of Echinoderms, Museum of Comparative Zoology, CAMbridge, Mass., U.S.A.

Plates I.-xuIv.; Text Figs. 1-11. 

SEA LILIES, STARFISHES, ETC.-CLARK.

\section{REPORT ON THE SEA-LILIES, STARFISHES, BRITTLE-STARS AND SEA-URCHINS.}

\section{I.-INTRODUCTION.}

THE collections dealt with in this report consist of the Echinoderms, excepting the Holothurians or Sea-cucumbers (beche-de-mer), or in technical terms the "Actinogonidiate Echinoderms," obtained by the Federal Fisheries Investigation Ship "Endeavour" along the Australian coast south of Lat. $24^{\circ} \mathrm{S}$. at depths of less than three hundred fathoms, during the years 1909-1914 inclusive. The Holothurians were by mutual agreement sent elsewhere for study.

The collections were sent to me in five instalments and have included altogether one thousand and sixty-one specimens representing one hundred and fifteen species, of which thirtynine seem to be new to science and fifteen others are now recorded from Australia for the first time. Others, previously known from northern Australia are now listed from stations south of the tropies, and the extension of ranges in this way is oftentimes very great. Up to the present time (1 July, 1915), the list of Actinogonidiate Echinoderms known from Australia was about three hundred and twenty, but owing to numerous cases of incorrect identifications and of inaccurate locality labels, it is impossible to give exact figures. There is no doubt, however, that including the large additions made by the "Endeavour," the known Echinoderm fauna of Australia includes more than three hundred and fifty valid species, aside from the Holothurians.

The geographical distribution of these species is very interesting. At least two hundred are endemic, or at least have not yet been reported from elsewhere, while most of the remainder are East Indian species, ranging southward along the eastern coast of the continent to southern Queensland or even to Port Jackson, New South Wales. In his very interesting and useful paper on the "Recent Crinoids of Australia,"1 Mr. Austin H. Clark has recognised the existence of a North Australian and a South Australian subregion, Port Jackson on the east coast and Shark Bay on the west serving as the approximate boundary between the two. Study of the Echinoderms as a whole (including the Holothurians), however,

1. A. H. Clark-Mem. Austr. Mus., iv., 15, 1911. 
indicates that such a division of the Australian marine fauna fails to bring out the interesting contrasts between the east and west coasts, and I would suggest the recognition of three Australian subregions as follows:-

1. East Australian subregion, extending from about $35^{\circ} \mathrm{S}$. Lat. to $15^{\circ}$, merging northward in the East Indian or, more properly, Indo-Pacific fauna of the Torres Strait district. Of the more than four hundred Australian Echinoderms now known, about sixty-five, or some $16 \%$ belong exclusively to this fauna. Some of the characteristic species are the following:-

\section{Crinoids.}

Comatula cratera.

Ptilometra mülleri.

Compsometra loveni.

Asteroids.

Mediaster monacanthus.

Anthenea acuta.

Astrogonium dübeni.

Ophidrans.

Conocladus amblyconus.

Ophiarachnella ramsayi.

Ophiura multispina.

ECHINI.

Prionocidaris australis.

Centrostephanus rodgersii.

Clypeaster australasia.

\section{Holothurians.}

Taniogyrus australianus.

Molpadia dissimilis.

Cucumaria mirabilis.

Some of the species characteristic of this fauna no doubt range south of Lat. $35^{\circ}$ and even reach Port Phillip, Victoria, but such cases are exceptional and do not invalidate the recognition of the subregion. The remainder of the more than two hundred Echinoderms known from the eastern coast of Australia, north of Shoalhaven Bight, New South Wales, are Indo-Pacific forms, many of which find a centre of abundance in Torres Strait. The distance southward to which they range differs greatly in different species, but it is evident from the "Endeavour" collection that most of 
them may range as far south as Wide Bay, Queensland, and some are known to reach Port Jackson, New South Wales.

2. South Australian subregion, including Tasmania and the mainland coast south of $35^{\circ} \mathrm{S}$. Lat. It merges on the east coast with the East Australian subregion, and some of its characteristic species reach Port Jackson. This is the typical Australian marine fauna and includes about one hundred and twenty species or approximately $30 \%$ of the known Echinoderms. More remarkable, however, is the fact that the great bulk of this fauna is endemic or at least is not at present known from elsewhere. Apparently not more than a dozen of the Echinoderms known from the southern coasts of Australia range north of Lat. $28^{\circ}$ or east or west of the Australian region. A very few (of which Ophionereis schayeri is a conspicuous example) occur in New Zealand. One (Echinus horridus) is known from South America and South Africa and perhaps more will ultimately be found with that range. One starfish (Luidia maculata) has the very unusual range of encircling the Australian continent and reaching China and Southern Japan on the north. The following are some of the most characteristic species of this remarkable fauna:-

Crinoids.

Comanthus trichoptera.

Ptilometra macronema.

Compsometra incommoda.

Asteroids.

Nectria ocellata.

Tosia aurata.

Pseudolinckia rhysa.

Plectaster decanus.

Coscinasterias dubia.

OpHIURANS.

Astroconus australis.

Ophiactis resiliens.

Ophiothrix spongicola.

ECHINI.

Goniocidaris tubaria.

Microcyphus annulatus.

Amblypneustes grandis.

Holopneustes porosissimus.

Heliocidaris erythrogramma. 


\section{Holothurians.}

\section{Leptosynapta dolabrifera. Pentacta spinosa.}

The western limit of this subregion is not easy to determine. The little work the "Endeavour" did in the Great Australian Bight revealed a very interesting fauna and suggests that many of the Echinoderms of the South Australian subregion do not extend their range west of $125^{\circ} \mathrm{E}$. Long. At any rate, there is no doubt that once Cape Naturaliste is passed, the Echinoderm fauna undergoes an appreciable change, although a few species from the south (as Ptilometra macronema) range northward to Geraldton, Western Australia.

3. West Australian subregion, extending northward from Lat. $35^{\circ} \mathrm{S}$.; the northern limit cannot be given as we know almost nothing of the echinoderm fauna between Lat. $20^{\circ}$ on the north-west coast to Port Darwin, a distance of more than a thousand miles. Some eighty-five species of Echinoderms are now known from West Australia; of these ten or a dozen are species of the South Australian subregion and rather more than thirty are species from the north, relatively few of which are, however, truly East Indian. More than forty species, or half the fauna, are peculiar to the subregion, so far as we know, and many of these are very remarkable forms, often representing peculiar genera. The following are some of the characteristic species:-

\section{Crinoids.}

Comatula etheridgei.

Petasometra helianthoides.

Neometra gorgonia.

\section{Asteroids.}

Nectria ocellifera.

Oreaster nodulosus.

Culcitaster anamesus.

Linckia tyloplax.

\section{Ophiurans.}

Conocladus microconus.

Astrogymnotes catasticta.

Ophiocreas adhorens.

Ophiothrix smaragdina. 


\section{ECHINI.}

Phyllacanthus magnificus.

Centrostephanus tenuispinus.

Peronella aphnostina.

\section{Holothurians. \\ Caudina tetrapora. \\ Colochirus axiologus.}

It is useless to speculate on the origin or significance of this West Australian fauna until we know the fauna of the north-western coast. The region between Shark Bay and Torres Strait should be thoroughly explored, and, as soon as possible, that between Melville Island and Timor. When this vast area is as well known as South-eastern Australia we shall be able to form an intelligent opinion concerning the West Australian subregion. We shall know then, too, whether we ought to recognise a North Australian subregion, and if so, whence its fauna came. There are some very characteristic species from that district, but they do not come within the scope of this report.

So far as the present evidence goes, it seems that the Western Australian fauna is a derivative of that of the South Australian subregion with a considerable element from the tropical Indian Ocean. The characteristic South Australian fauna is clearly derived from that of the east coast with at least a small addition from a southern fauna common to South Africa and southern South America. The exact extent and significance of this southern element is one of the most interesting and least known features of the South Australian fauna. There is little question that the East Australian fauna is derived directly from the Indo-Pacific and is still closely associated with the fauna of the East Indies and the Pacific Islands. Whether any of the east coast fauna has been received through Torres Strait or whether it has all come around the eastern end of New Guinea, or whether it is largely of southern origin and has spread northward and eastward, are still questions to be answered, but I see very little evidence indeed in favour of the latter view.

In the above discussion, I have obviously omitted all reference to other groups of animals, believing I could best do my part in the solution of the problem by presenting simply the evidence offered by the group I am studying. I believe the Echinoderms are a very satisfactory group by which to test possible lines of migration, the great antiquity of the phylum, the relatively small number of genera and species 
and the general distinctness of lines between the classes and orders, all tending to make a correct interpretation of the distribution at least hopefully feasible. Of course, we are just beginning to approach the problem and do not as yet know all of its factors, but the possibility of a solution cannot be fairly denied. The collections made by the "Endeavour" have certainly thrown a flood of light on the composition of the Australian Echinoderm fauna, and hence bring us that much nearer to a knowledge of its origin.

For the honour done me in entrusting these valuable collections to me, and for the privilege of studying them, I desire to express my thanks to the Minister of Trade and Customs of the Commonwealth of Australia, Honourable Frank Gwynne Tudor, and to the former Comptroller-General for Trade and Customs, Nicholas Lockyer, Esq., I.S.O., and, of course, to Mr. Robert Etheridge, Curator of the Australian Museum. Since my correspondence has been entirely with Mr. Etheridge, I cannot forbear the expression of my great appreciation of his uniform courtesy, consideration and patience. To collaborate with him in scientific work is indeed a great pleasure.

\section{II.-Description of the Genera and Species.}

\section{CRINOIDEA.}

The Crinoids collected by the "Endeavour" are of the greatest interest. There are two hundred and sixteen specimens, representing sixteen species, eight of which seem to be new to science, and ten genera, of which three have not previously been recorded from Australia. IIore than half the specimens (one hundred and forty-four) represent a single well-known species, while five species are represented by only a single specimen each, and five others by only two each. Of the eight species previously known to science, all have been recorded from Australia before, indeed seven of them are characteristic of the Australian fauna and only two have been reported outside this region. The "Endeavour" collection extends, often very considerably, the known range of four of these eight species. Undoubtedly the magnificent new stalked crinoid from off the south-eastern corner of the continent is the most notable form taken, but the new species of Oreometra and Cosmiometra are very fine. The number of species of Crinoids now recorded from Australia is sixty-six, not including those taken in depths exceeding three hundred 
fathoms nor those known from Sahul Bank (south of Timor); of the sixty-six, thirty-seven, or more than half, are known only from Australia.

\title{
Family PENTACRINITIDAE.
}

Genus Metacrinus, $P$. H. Carpenter.

\author{
Metacrinus Cyaneus, ${ }^{1} s p$. nov.
}

\section{(Plate 1.)}

Stem rather stout, apparently not exceeding $400-500 \mathrm{~mm}$. in length, and ranging from 5 to $8 \mathrm{~mm}$. in diameter in the different specimens; pentagonal in cross section, with slightly rounded angles; immediately beneath the calyx, the sides are grooved and the angles sharp, but after five or six nodes, the grooves and angles have virtually disappeared. Cirrus sockets confined to the nodals, transversely oblong, the shorter diameter markedly less than the height of the nodal, one-fourth of which lies below the sockets. Nodals not at all produced at angles, nor otherwise conspicuous, but occasionally a low swelling is indicated on the rounded angle. Internodals 7-15, but rarely fewer than 9; the uppermost becomes fused with the nodal on the lower half of the stem; the upper and lower margins are prettily crenulated along the suture, except on the lowest internodes; their radial faces are plane (except on uppermost internodes) while the internodal angles may bear low, rounded swellings (scarcely large enough to be called tubercles), though these are often entirely wanting; the internodals in some specimens are of nearly uniform height, but generally alternate internodals are higher than those between; this difference may be very marked, especially on the uppermost internodes; along the midradial line of the upper internodes, there is a conspicuous pit between each pair of stem-segments (nodals and internodals alike), but this vertical series of pits becomes indistinct at about the ninth or tenth internode and lower down completely disappears; the lower internodes have a smooth, shining, porcelain-like surface, but the upper ones lack this entirely.

Cirri 50-65 mm. in length (eight to ten times the stemdiameter), the longest with 60-64 segments; basal segments low (not half as high as wide), gradually becoming higher, but never becoming even approximately as high as wide ; terminal claw scarcely longer than the preceding joint, slightly curved:

1. Kváyєos=dark blue, dusky, in reference to the colour of the stem. 
there are more or less evident median tubercles on a dozen or fifteen of the terminal segments; there tend to be two on each segment but they are very low and small as a rule. Cirri transversely oval in cross-section at base, but soon become cylindrical and distally more or less laterally compressed. Fully developed cirri have a smooth, polished surface, as usual.

Basals rather prominent, somewhat produced downward over the angles of the stem, broadly in contact laterally. Radials two or three times as wide as high, with a marked proximal angle (between the basals) and a distinctly concave distal margin. IBr normally $6(1+2,4+5),{ }^{1}$ but often 7 $(1+2,4+5)$, occasionally $5(1+2)$ and rarely 4 with no syzygy. Axillary triangular, almost as high as wide, lateral angles truncate, distal angle somewhat rounded. Pinnules on second, third and fifth segments and on sixth when seven are present. IIBr $6-11$, usually 9 or 11 , not rarely 7 , but 6 only in one instance; a syzygy between 3 and 4 ; in one instance the syzygy is between 2 and 3 instead. IIIF $\mathbf{r}$ almost always present, 9-21, usually 13 or 15 ; a syzygy between 3 and 4 . IVBr often present, 16-27, usually 19 or 21 ; more generally present on the outer, than on the inner IIIBr series. Arms 45-60 (57 in holotype), with about 140 brachials after the IVBr series; articular tubercles slightly indicated; dorsal surface smooth; beyond the IIIBr axillary the brachials have somewhat flaring distal margins, more or less spinulose at first, but becoming smooth near arm tip ; distally the arms are somewhat compressed ; the arms of the holotype are more than $200 \mathrm{~mm}$. from the radial to the tip. Oral surface of arms with numerous granules and little plates, which are particularly crowded along the margins of the food-groove.

Pinnules rather stout, four-sided, somewhat flattened; each segment is more or less concave or hollowed out on both the proximal and distal sides; this is very marked on distal side of first pinnule but on the second is nearly wanting, the distal margin of the latter being compressed and keel-like; subsequently the concavity of the distal and proximal sides of the pinnules becomes a constant feature; the oral surface of each pinnule is provided with granules which guard the foodgroove; the terminal half of each pinnule is thus covered orally by a double, interlocking series of pointed granules. First pinnule (that on $\mathrm{IBr} 2$ ) about $20 \mathrm{~mm}$. long with 17-18 segments ; second somewhat longer ; third a little longer than

1. Not counting the radials themselves, of course. 
second; fourth (that on IIBr 4) about $25 \mathrm{~mm}$. long, with $22-23$ segments ; fifth about as long; sixth a little shorter ; succeeding pinnules decrease in length very gradually, becoming about $10 \mathrm{~mm}$. long, with 15 or 16 joints; this size continues to the terminal part of the arm, where, about fifty segments from the tip, it drops quickly to $2 \mathrm{~mm}$. and less, with only three segments or even fewer; there are half a dozen or more intermediate pinnules with $12,10,8$ and 6 joints, but the transition is quite abrupt as is usual in the genus.

Colour (in alcohol or dried from alcohol) either uniformly light bluish-grey, or crown pale yellow or whitish, and stalk deep greenish-blue in marked contrast. The holotype (in alcohol) is uniformly whitish with a distinct orange tinge, but only a small part of the stalk is attached to the magnificent crown. The stalk of this specimen, preserved dry, is deep greenish-blue. Unfortunately there are no notes on the colour in life, of any of the specimens, but it is not likely that the bluish shade in the stalk is the result of preservation. It is possible that the yellowish crowns are the result of preservation in alcohol. There are seven specimens.

This superb crinoid is well distinguished from all the previously described members of the genus by the large number of segments in all the various numerical series; thus the number of internodals (usually more than 9 and often 14) is the maximum for the genus, the number of cirrus-joints is nearly the maximum, the number of radials is often the maximum, and the segments of both the IIBr and the IIIBr series approach the maximum number. In certain particulars, $\boldsymbol{M}$. rotundus, Carpenter, seems to be the nearest relative of $M$. cyaneus, but it has decidedly fewer cirrus-joints, and the distal brachials are not at all flaring, the arms being quite smooth; moreover the radials and the members of the $\mathrm{IBr}$ series are stouter, smoother and of quite a different shape in $M$. rotundus. As the only stalked crinoid as yet known from the coasts of Australia1, Metacrinus cyaneus is of unusual interest and will certainly rank as one of the "Endeavour's" most noteworthy discoveries. The geographical isolation of $M$. cyaneus is remarkable, the Kermadec Islands, nearly 2500 miles to the north-east being the nearest locality where Metacrinus has been taken.

Locs.-Eastern Slope, Bass Strait, about 200 fathoms. This specimen has been selected as the holotype.

South-east of Wilson's Promontory, Victoria.

1. Sahul Bank, south of Timor, is scarcely Australian. 
Twenty and a half miles S., $19^{\circ}$ E. of Cape Everard, Victoria, 90 fathoms.

One good specimen from an unknown locality, but the appearance leaves little room for doubt that it is from the station south-east of Cape Everard, Victoria.

Family COMASTERIDE.

Genus Comatula, Lamarck.

Comatula Cratera, ${ }^{1} s p$. nov.

(Plate II., fig. 1.)

Disk of holotype, $13 \mathrm{~mm}$. across ; arms $175 \mathrm{~mm}$. or more in length, $4 \mathrm{~mm}$. in transverse diameter at base, $5 \mathrm{~mm}$. at 20 $\mathrm{mm}$. distance from base, and $3 \frac{1}{2} \mathrm{~mm}$. at $50 \mathrm{~mm}$. from base. Centrodorsal pentagonal, $4 \mathrm{~mm}$. in diameter; its sides are straight or more or less concave; it is flush with the radials, all of which are fully exposed. Cirri none in the holotype and eight other specimens; in three specimens, a single small cirrus is present in each; one specimen has two and one has three such cirri, each with $16-19$ joints. The second radial is more than twice as high as the first and half again as wide; the third (axillary) is triangular, nearly twice as wide as high. Brachials (heyond the tenth) broadly triangular, the pinnulebearing end three times as wide as the other; the distal margin is slightly concave and projects as a faint articular tubercle where the brachial is widest; the lowest brachials are nearly equally wide on the two sides and have the articular tubercle more marked on their proximal margins, but these tubercles are never conspicuous. Along the median line of the arm is a slight keel ; it is better marked on some brachials than on others and the degree of development differs in different specimens. Syzygies between br. 1 and 2, and 3 and 4 and then at intervals of 5-7 joints to about br. 30 , after which the usual interval is 5, though 4 or 6 occur frequently. Pinnules rather stout but becoming long and slender distally; $P_{1}$ about $20-25 \mathrm{~mm}$. long, with some 45 segments, of which not more than 12-15 make up the small terminal comb; succeeding pinnules successively shorter to $\mathrm{P}_{8}$ which is about $16 \mathrm{~mm}$. long and has some 25 segments; terminal combs confined to first three pairs of pinnules; basal segments on

1. K ратєрa-strong, stout, in reference to the unusually thick arms. 
all pinnules, much wider than high, and somewhat compressed, especially at distal margin; on $\mathrm{P}_{2}, \mathrm{P}_{3}, \mathrm{P}_{a}$, and $\mathrm{P}_{b}$, this compressed distal margin becomes a conspicuous projecting keel on segments 2 and 3 ; beyond $\mathrm{P}_{8}$, the pinnules. gradually lengthen and become more slender until they may exceed $20 \mathrm{~mm}$. in length and have 35 segments.

Mouth radial in position, not very close to margin of disk, with equally developed food-grooves running to all the arms. There is no plating of disk or of the oral surface of arms and pinnules, but the membrane covering the disk is, when fully dried, seen to be filled with calcareous granules of very small size. Colour (in alcohol or dried), light fawn-colour with or without purple markings; perhaps in life all would show these purple markings more or less clearly; when welldeveloped they appear as longitudinal stripes one on each side of each arm, with a branch runnning up each pinnule; distally the stripes fade away altogether; proximally the stripes on the inner side of a pair of arms unite at the tip of the axillary from which they arise, while those on the outer side broaden out and cover the radials except for a narrow median area; even the centrodorsal may be purplish; the disk and oral surface of the arms are yellowish, quite yellow when dry.

Whether this fine comatulid should be considered distinct from $C$. solaris is, of course, a matter of opinion. The locality is some four hundred miles further south than $C$. solaris has been recorded and the depth is considerably greater than any published for that species. In view of these facts, it seems to me that the absence of cirri and reduction of the centrodorsal plate, combined with the very different terminal combs of the oral pinnules and the absence of plating on disk and oral surface of the arm bases, warrant the recognition of the form by a different name. In $C$. solaris the terminal comb of $\mathrm{P}_{1}$ consists of 35-40 segments and occupies nearly half the pinnule; the shape of the individual teeth is, moreover, very different from what is seen in $C$. cratera. The comatulid taken by the "Alert" at Port Molle, Queensland, referred by Carpenter to $C$. solaris, but specially discussed because of the absence of cirri and the unplated disk, is very possibly a specimen of $C$. cratera.

Loc.-Eight miles east of Sandon Bluffs, New South Wales, 35-40 fathoms. Fourteen specimens. 
Genus Comanthus, A. H. Clark.

Comanthus Perplexum, ${ }^{1} s p$. nov.

$$
\text { (Plate III., fig. 2.) }
$$

Centrodorsal well developed, nearly $5 \mathrm{~mm}$. in diameter, slightly concave; around its margin is a series of about 15 cirrus-sockets, 7 or 8 of which bear more or less developed cirri ; the largest of these are about $13 \mathrm{~mm}$. long and consist of 16-19 segments, of which the terminal 3 or 4 , aside from the claw, carry very insignificant elevations or ridges on the proximal dorsal margin. $\mathrm{IBr}$ series, 3 , all visible, the axillaries broadly triangular, not in contact interradially. IIBr $4(3+4)$, low, broad, smooth and practically without articular tubercles; distal margins distinct, slightly flaring, especially on $\mathrm{IIBr}_{2}$; the whole series is only $5 \mathrm{~mm}$. long and is nearly $4 \mathrm{~mm}$. wide. IIIBr series 2 , except on one IIBr series, where one arm has a IIIBr series $4(3+4)$ and the other arm is undivided. There are $4 \mathrm{IVBr}$ series present, all $4(3+4)$ and there are thus 44 arms; these are about $100 \mathrm{~mm}$. long and have approximately 100 segments beyond the last division; there is a syzygy between 3 and 4 , and a second ten to fifteen segments beyond; after that the syzygial interval is 5, with remarkable uniformity. Brachials quadrilateral but except near tip of arm, the pinnular side is much wider than the one opposite ; distal margins flaring, thickened and minutely rough but not spinulose. Pinnules rather slender; $\mathrm{P}_{1}$ about $17 \mathrm{~mm}$. long, with 45 segments, of which only the terminal 10 form the comb; $\mathrm{P}_{2}$ shorter with about 35 segments, 10 in the comb; $P_{3}$ remarkably short and weak, scarcely $5 \mathrm{~mm}$. long and consisting of only 18-20 segments, the terminal comb of 7 segments is well-marked; none of the subsequent pinnules have a comb, but they gradually increase in length to $10 \mathrm{~mm}$. or more, still consisting, however, of about 20 seginents; none of the segments are conspicuously spinulose, though the terminal ones are more or less so, but the basal segments are notably triangular. Disk wanting. Colour (dry), uniformly pale fawn; oral surface of arms and pinnules brownish-black.

There is no doubt that this species is very near $C$. briareus (Bell), but after comparison with numerous specimens, I am unwilling to refer it to that species. The colour is naturally the most striking difference, but, of course, is the least

1. Perplexus=puzzling, in reference to the doubt whether it is really a distinct species. 
significant; nevertheless it is noteworthy that all recorded specimens of $C$. briareus and all of the thirty specimens at hand are blackish-brown, brownish-black, or purplish-black; one recorded from Western Australia by A. H. Clark has lighter lines on the arm. Aside from colour, the flaring distal margins of the low radials and of the brachials in $C$. perplexum are quite different from those of $C$. briareus, while the smoothness of the brachials and pinnules is noticeable, as contrasted with the rough arms of $C$. briareus. I have carefully compared the single specimen with the descriptions of $C$. weberi and $C$. rotula of A. H. Clark, at the kind suggestion of that well-known authority on the group, but the cirri show at once that it is not $C$. weberi, and the characters of the centrodorsal, the cirri and the brachials seem sufficient to distinguish it from $C$. rotula. The geographical isolation of this interesting comatulid is remarkable for no near relative has been taken south of Port Molle and $C$. briareus is not known from south of Port Denison, some six hundred miles to the north.

Loc.-Eleven miles south by east of Ballina, New South Wales, 27-28 fathoms.

\section{Comanthus PleCtrophorum, ${ }^{1} s p$. nov.}

$$
\text { (Plate IV., fig. 1.) }
$$

Disk about $30 \mathrm{~mm}$. in diameter; arms rather more than $100 \mathrm{~mm}$. long. Centrodorsal about $10 \mathrm{~mm}$. in diameter and more than $2 \mathrm{~mm}$. thick; its bare central area is very rough, slightly concave and about $6 \mathrm{~mm}$. across. Cirrus-sockets in three crowded and irregular horizontal series. Cirri LV.-LX., 29-37, usually about 32 ; some proximal segments, say 4-9, are cylindrical and longer than thick, 5 is particularly long; beyond 10 the distal dorsal margin projects slightly, the segments become compressed and a marked dorsal keel is formed, which is most fully developed on the four or five segments preceding the penultimate; seen from the dorsal side this is more of a tubercle than a keel, but the lateral aspect is very keel-like.

Radials entirely concealed; IBr 1 wide and low, in contact for about three-fourths of their height; radial axillaries, very low and wide, at least three times as wide as high, not at all in contact with each other. IIBr series $4(3+4)$, in one instance only, 2, well separated from each other externally ; internally $\mathrm{IIBr}_{1}$ are more or less in contact. IIIBr series

1. $\pi \lambda \hat{\eta} \kappa \tau \rho o \nu=a$ spur $+\phi o \rho \hat{\epsilon} \omega=$ to bear, in reference to the notable spurs on the pinnules. 
$4(3+4)$, in two instances only, 2 ; in the dry specimen the distal margins of this series and the preceding are thickened and slightly flaring and there is little indication of synarthrial tubercles, but in the alcoholic specimen while very slight synarthrial tubercles are indicated the joints are all smooth and indistinct. IVBr series, when present, $4(3+4)$; not present at all in the dry specimen, but four such series are present in the alcoholic. Arms 40-44, terete; brachials soon become very markedly triangular, with thickened, flaring, roughened distal margins, but distally they again resume a quadrilateral form and the distal margins are not peculiar. A syzygy occurs between 3 and 4 and then at a variable distance of 8-16 segments; after the second syzygy there may be a second interval of $8-10$ segments, but as a rule syzygies become frequent and very regularly spaced, in one specimen at intervals of 5 segments and in the other at 6 ; that is, in one specimen each syzygial pair is followed by 3 normal segments and then another syzygial pair, while in the other specimen, 4 normal segments intervene.

Pinnules long and slender, especially the oral pinnules, of which the first exceeds $30 \mathrm{~mm}$. in length and consists of more than 70 segments; succeeding pinnules decreasing in length to $\mathrm{P}_{4}$ which is only about $15 \mathrm{~mm}$. long and contains only $20-25$ segments. Comb of lowest pinnules consists of about 12-15 segments; the combs persist as far as $\mathrm{P}_{\mathbf{4}}$ on which the comb consists of 7 or 8 segments. Basal segments of all pinnules, except at very tip of arm, much wider than long; on the basal and middle portions of the arm, 3-12 of these widened sements are conspicuous for their flaring, spinulose margins, which are prolonged on the aboral side into remarkable spinulose spurs; these spurs are, of course, largest and most fully formed on the basal segments (excepting the lowest two) of the lowest pinnules; passing distally along the arm, as well as along each pinnule, these spurs become less and less evident and finally disappear. Disk quite fully plated, especially along the food-grooves ; the position of the mouth cannot be determined in these specimens. Colour (of alcoholic specimen) light brown; cirri somewhat lighter than arms ; on drying, the colour becomes uniformly light fawn or very pale buff.

This is a very well characterised and remarkable Comanthus, related to $C$. bennetti and $C$. pinguis, but easily distinguished from either, by the curious pinnule segments. The small number of arms and the colour will further distinguish it from $C$. bennetti, while the shape of the arms, especially at 
base, separate it from $C$. pinguis. From the South Australian species $C$. trichoptera, the size, the cirri and the pinnules all distinguish it without difficulty.

Loc.-East of Flinders Island, Bass Strait, 100-300 fathoms. Two specimens.

\section{Comanthus SPanoschistum, ${ }^{1} s p . n o v$.}

$$
\text { (Plate IV., fig. 3.) }
$$

Disk 5-12 mm. in diameter; arms 30-80 mm. long. Centrodorsal large and flat, $5 \mathrm{~mm}$. in diameter in adults, and about $1 \mathrm{~mm}$. thick. Cirri, in one or in two imperfect series, about XXIV., $15-20$; the longest are $10-15 \mathrm{~mm}$. long; segments 4-7 or 3-8 are cylindrical and longer than wide, segment 4 (or 5) may be nearly twice as long as thick; distally the segments are a trifle compressed and the distal margin dorsally is elevated to form a low tubercle, which, at least on the penultimate segment, is spiniform. Radials hidden; IBr 1 low and wide, more or less in contact; radial axillary triangular, high and pointed, the height about two-thirds of the width. IIBr series, not often developed; when present, invariably $4(3+4)$; arms usually 10 , in one specimen 13 , in another 14 , and in a third 19; No IIIBr series is developed. Brachials at first quadrilateral, but soon becoming triangular; distal margins becoming more and more flaring and overlapping until near tip of arm where the brachials become quadrilateral again and the margins hardly flare. Syzygies between 3 and 4 and then at an interval of 7-11 segments; after that the syzygial interval is usually 5 , but may be only 3 . Pinnules long and slender; $P_{1}$ is over $10 \mathrm{~mm}$. long and consists of about 30 segments, of which about 15 make up the comb; $\mathrm{P}_{2}$ is somewhat smaller and $P_{3}$ is only $8 \mathrm{~mm}$. long and consists of 20 segments, 9 in the comb; $P_{4}$ is $8 \mathrm{~mm}$. long, but has no comb ; succeeding pinnules become more slender and increase in length to about $10 \mathrm{~mm}$.; basal segments of lower pinnules, more or less triangular with greatly flaring, spinulose margins which tend to project like rough spurs on the aboral side of the largest segments, much as in the preceding species $(C$. plectrophorum). Disk, except around tip of anal tube, smooth and naked; there are calcareous nodules in the anal tube. Mouth interradial. Colour, in alcohol and dry, more or less yellowish, with either a green or a brown cast; one

1. $\sigma \pi a \nu o^{\prime}=$ rare $+\sigma \chi \iota \sigma \tau o ́ s=$ divided, in reference to the scarcity of arm divisions. 
specimen is very dull purplish with yellow cirri; others are yellowish more or less clouded with purplish ; in the 19-armed individual the dull purplish predominates. Twenty-three specimens.

The specimen from off Noosa Head, Queensland, is noticeably more slender than the others and the cirri are somewhat more compressed but these differences are very slight and no more than one might expect in view of the wide separation of Noosa Head from the Tasmanian waters where this species seems to be so common. It is no doubt nearly related to $C$. trichoptera, but the scarcity of division series and the absence of the peculiar axillaries characteristic of that species, would seem to preclude regarding the two as identical. Many of the specimens, even small ones, have the genital pinnules immensely swollen with the reproductive cells; in some cases only the pinnules near the tip of the arm are unaltered. The specimens which have dates on the labels were taken in March and April, 1914, and thus it is evident that the species breeds in late summer and early fall. It is possible, of course, that it has a prolonged breeding period.

Locs.-East of Babel Island, Bass Strait, 60-70 fathoms and 50-80 fathoms.

North-east of Babel Island, Bass Strait, 100-170 fathoms.

Twenty miles east of Babel Island, Bass Strait, 65 fathoms.

East of Maria Island, Tasmania, 78 fathoms.

East of Flinders Island, Bass Strait, 70-100 fathoms.

Eastern Slope, Bass Strait, 70-120 fathoms.

Off Noosa Head, southern Queensland, 16 fathoms.

Family ZYGOMETRID E.

Genus Zygometra, A. H. Clark.

Zygometra ELEGANS (Bell).

Antedon elegans, Bell, Rep. Zool. Coll. H.M.S. "Alert," 1884 , p. 162.

Zygometra elegans, A. H. Clark, Smiths. Misc. Coll., 1., 1907 , p. 348.

The occurrence of this comatulid as far south as Sandon Bluffs, New South Wales, is an interesting extension of its range, since it is not recorded from a lower latitude than that of Port Curtis, Queensland. The three specimens are all of 
large size (arms nearly $100 \mathrm{~mm}$. long), but show considerable diversity of colour. One has 38 arms, the greater part of which are light brown, but basally all are heavily shaded with purple, the joints in particular being very dark; there are 35 cirri with about 54 segments ; they are, at base, dorsally pale brown, orally deep purple, but distally the purple becomes very gradually dominant until it includes all of both surfaces. The second has at least 36 arms (several are missing) which are light brown with more or less of a purplish cast; basally three of the rays are very deep purple, the other two being decidedly lighter; there are more than 30 cirri with 47-53 segments, light brown at base, but becoming purple distally. The third specimen, from off Noosa Head, Queensland, has only 29 fawn-coloured arms (dry), with a faint purplish cast, the joints distinctly darker than the segments; there are, in marked contrast, 27 dull purple cirri, pale brownish at base dorsally (as in the centrodorsal), with 45-47 segments. In this dry specimen the IIIBr series is 2 except in one instance of $4(3+4)$ but in the other specimens it is common to have the IIIBr series $4(3+4)$, although 2 seems the usual number. The IIBr series, and the IVBr series, when present, are invariably $4(3+4)$. The only $\mathrm{VBr}$ series noted is 2 .

Locs.-Eight miles east of Sandon Bluffs, New South Wales, 35-40 fathoms.

Off Noosa Head, southern Queensland, 16 fathoms.

\section{ZYGOMETRA MICRODISCUS (Bell).}

Antedon microdiscus, Bell, Rep. Zool. Coll. H.M.S. "Alert," 1884, p. 163.

Zygometra microdiscus, A. H. Clark, Smiths. Misc. Coll., 1., 1907, p. 348.

This is a small, dry specimen of uniformly pale brown colour, with only $22 \mathrm{arms}$. There are $8 \mathrm{IIBr}$ series, one of which is 2 , the rest $4(3+4)$; there are 4 IIIBr series, all of which are $4(3+4)$. The centrodorsal is low, conical, with 25-30 cirri, the longest having more than 40 segments. $P_{2}$ has 27 segments and is relatively large, but is less than $20 \mathrm{~mm}$. long. The occurrence of this species near the Capricorn Islands is quite to be expected, but nevertheless extends the known range of the species far to the south. The present specimen is naturally referred to Carpenter's Antedon multiradiata, but I think A. H. Clark is quite right in regarding that species as a synonym of $Z$. microdiscus.

Loc.-Thirteen miles north-east of North Reef, Capricorn Group, off Port Curtis, Queensland, 70-74 fathoms. 


\section{Family CALOMETRID E.}

Genus Oreometra, A. H. Clark.

OREOMETRA PERICALles, ${ }^{1} s p$. nov.

(Plate III., fig. 1.)

Disk wanting; centrodorsal $6 \mathrm{~mm}$. in diameter. Cirri all missing, but cirrus-sockets 17 , their ventral portion well on to the radials; centrodorsal slightly convex, smooth. IBr 1 and 2 (the axillary) united by syzygy; radials in contact laterally, but IBr 1 and 2 clearly separated from the adjoining series; each of these segments is about three times as wide as high and 2 has a low, obtuse distal angle; there is a cylindrical, blunt, spine-like tuberele (sometimes a pair) on the proximal margin of 1 and another on the distal margin, in the median line; there are 1-3 somewhat similar but flattened projections on each anterior margin of the axillary. $\mathrm{IIBr}$ series $4(3+4)$, or once, $3(2+3)$; segments $1-3$ have the spine-like tubercle at the median, distal margin prominent, while the axillary may have one somewhat smaller, on each side; an additional similar tubercle may be developed in connection with the well-marked distolateral angles. Lower brachials quadrilateral with conspicuous distolateral angles on the pinnular side; the median spine-like tubercle is also often developed; after the seventh or eighth, the brachials tend to become triangular and the distal margins tend to flare, but there is no overlapping. Syzygy between 2 and 3 on every arm, with a IIBr series, but between 3 and 4 on arms arising direct from the radial axillary; second syzygy is somewhere between the eighth and fourteenth segments; after that the syzygial interval is five or six segments.

$P_{1}$ somewhat prismatic, about $7 \mathrm{~mm}$. long, of about 15 segments, curved inward, flexible, but not at all flagellate, rather stout throughout; the first segment is notably enlarged, but not the second; $\mathrm{P}_{2}$ erect, and spine-like, not at all prismatic, about $13 \mathrm{~mm}$. long, of 15 nearly cylindrical segments, with spiny distal margins, all but the terminal and 2 lowest, longer than thick; $P_{3}$ very similar, perhaps a little longer; $\mathrm{P}_{4}$ similar, perhaps a little shorter than $\mathrm{P}_{3} ; \mathrm{P}_{5}-\mathrm{P}_{10}$ similar, but successively shorter and with fewer segments, which have less and less spiny distal margins; $P_{11}$ of 11 segments and about $8 \mathrm{~mm}$. long; succeeding pinnules distinetly prismatic and gradually increasing to about $10 \mathrm{~mm}$. in length. Side and covering plates well developed. Arms about $75 \mathrm{~mm}$. long.

1. $\pi \epsilon \rho \kappa \iota \lambda \lambda \eta \dot{~} \varsigma=$ very pretty, in reference to both form and colouration. 
Colour, of the single dry specimen, purple and white; centrodorsal, dorsal surface of brachials and of pinnules, and scattered spots elsewhere, white or whitish; IBr series dirty whitish with a purple tinge ; IIBr series, a few of the lowest brachials, a conspicuous line along each side of each arm, and oral surface of pinnules, at least on basal portion, more or less deep purple.

This very handsome species was at first referred to Zygometra on account of the syzygy in the radial axillary. Mr. A. H. Clark kindly suggested comparing it with Calometra and the examination of the pinnules indicated relationship to that genus. I think there can be no doubt, however, that this specimen is a representative of the recently described genus Oreometra and it is quite near the type-species, O. marice, A. H. Clark. The differences in the IBr series and in the pinnules, however, forbid referring it to that species. The occurrence of a syzygy between brachials 2 and 3 is noteworthy; Mr. Clark says nothing about syzygies in either one of his two published descriptions of $O$. marice. He does say, however, that the connection between $\mathrm{IBr} 1$ and 2 is "an exceedingly close synarthry," while I have been convinced after a careful examination of the distal face of $\mathrm{IBr} 1$ that the joint is certainly not a synarthry in the present species and I do not see why it is not a syzygy. If it is a syzygy or a pseudosyzygy, it seems to me the genus is a connecting form with the Zygometridæ, if not actually a member of that family. The pinnules obviously count against any such view. The cirri I have not seen.

Loc.-Thirteen miles north by west of Double Island Point, Queensland, 25-26 fathoms.

\section{Family HIMEROMETRIDA.}

Genus Amphimetra, A. H. Clark.

\section{AMPHImetra CRENUlata (Carpenter).}

Antedon crenulata, Carpenter, Journ. Linn. Soc., Zool., xvi., 1882, p. 507.

Amphimetra crenulata, A. H. Clark, Smiths. Misc. Coll., lx., 10,1912, p. 16.

This is a fine adult individual with 28 arms; it had about 25 cirri, the longest with 45 segments. The colour (dry) is uniformly brownish-white. The species was not previously known from south of Port Curtis, Queensland.

Loc.-Thirteen miles north by west of Double Island Point, Queensland, 25-26 fathoms. 
"ENDEAVOUR" SCIENTIFIC RESULTS.

Family COLOBOMETRIDA.

Genus Oligometra, A. H. Clark.

Oligonetra thetidis, H. L. Clark.

Oligometra thetidis, H. L. Clark, Mem. Austr. Mus., iv., 11, 1909 , p. 522.

These two specimens are uniformly yellowish in alcohol and show no noteworthy peculiarities.

Loc.-Eastern Slope, Bass Strait.

OLIGOMETRA ZeBRA, ${ }^{1} s p$. nov.

(Plate II., fig. 2.)

Disk wanting; arms about $70 \mathrm{~mm}$. long. Centrodorsal, $3 \mathrm{~mm}$. in diameter, markedly concave. Cirri in a single, crowded, fairly regular marginal series of about 20 , 12-13 mm. long, each with 27 or 28 segments; all segments wider than long; basal ones nearly square but distally each successive segment becomes more compressed, ventrally rounded, and dorsally transversely ridged; transverse ridges never conspicuous, but more evident on the last four segments (not counting the claw), especially on the penultimate, where it forms a well-marked opposing spine. IBr series not peculiar, the synarthrial tubercle, however, being quite distinet; the axillary is nearly twice as wide as high; the adjoining rays are well separated from each other. Arms 10 ; brachials at first quadrilateral, becoming triangular, and then near tip of arm again quadrilateral ; synarthrial tubercle of 2 and 3 well-marked; neither distal margins nor distolateral angles peculiar, though the latter are evident enough, especially on terminal half of arm; general contour of arm quite smooth.

$P_{1}$ about $7 \mathrm{~mm}$. long, of 18 segments, not at all rigid or otherwise peculiar; the basal 6 or 7 segments are wider than long while the succeeding are squarish, or a little longer than wide; the oral margins of the lower segments are barely produced into one or two minute spines, while the aboral margins are inconspicuous, flattened and a trifle roughened; segments 8-12 are somewhat prismatic and the remaining segments are distinctly flattened. $\mathrm{P}_{2}$ is $9 \mathrm{~mm}$. long, with $18-20$ segments ; it is very similar to $P_{1}$ but is evidently stouter and is clearly the largest pinnule on the arm ; the oral margins of

1. Zebra, a Latinised form of the native name of the well-known African quadruped; in reference to the colouration of the arms. 
the basal segments are smooth, while the aboral margins are more or less produced as flattened, spinulose projections; the distal margins of all the segments, except the first five or six are finely spinulose, but none of these characteristics are at all conspicuous. $\mathrm{P}_{3}$ is much like $\mathrm{P}_{2}$, but a little smaller, while $\mathrm{P}_{4}$, which is probably the shortest pinnule on the arm, is only a trifle shorter than $\mathrm{P}_{3}$; succeeding pinnules become very slender, $8-9 \mathrm{~mm}$. long and with 22 or more segments. On the basal half of the arm, the pinnule-segments, except the basal two or three, have distinctly, but finely spinulose aboral edges and distal margins, but on the outer half of the arm they seem to be quite smooth.

Colour (dry) of centrodorsal, basal portion of the cirri, all arm-segments and pinnules, uniformly pale buff or brownishwhite ; cirri gradually become dull purple at tip, the lighter shade being confined more and more completely to the ventral side of the segments and finally is crowded out altogether; arm joints rich reddish-purple, in sharp and handsome contrast to the light segments; oral surface of pinnules very dark, almost black. One specimen.

This seems to be a well-marked species, the long cirri, the flexible first pinnule, and the absence of conspicuous processes on the basal pinnule-segments combining to distinguish it at once from the other species of the genus.

Loc.-Eleven miles east-south-east of Clarence River mouth, New South Wales, 35-36 fathoms.

Family THALASSOMETRIDE.

Genus Ptilometra, A. H. Clark.

Ptilometra macronema (Müller).

Comatula macronema, Müller, Monatsb. K. Preuss. Akad., 1846 , p. 179.

Ptilometra macronema, A. H. Clark, Smiths. Misc. Coll., l., 1907, p. 358.

These ten specimens are all typical examples of this characteristic South Australian species.

Locs.-Great Australian Bight, about $131^{\circ}$ E., 62 fathoms.

South-east of Flinders Island, South Australia, 37 fathoms.

Sanders Bank, off Kangaroo Island, South Australia, 28 fathoms.

Forty miles west of Kingston, South Australia, 30 fathoms. 


\section{Ptilometra mülleri, A. H. Clark.}

Ptilometra mülleri, A. H. Clark, Proc. Biol. Soc. Washington, xxii., 1909, p. 41.

This large series of Ptilometras (one hundred and fortyfive specimens) shows no tendency to intergrade with the preceding species and fully justifies Mr. Clark's separation of the two forms The occurrence of this species off the mouth of the Clarence River, New South Wales, extends its known range northward about 150 miles. It is interesting to note that no Ptilometras were taken by the "Endeavour" in Tasmanian or Victorian waters, though the genus has been reported from Port Phillip. None of the material in the present collection throws any light on the disagreement between Mr. A. H. Clark and myself with reference to the young of Ptilometra. We are each equally sure of being right, and no doult will continue to feel so until the life history of one of the members of the genus is fully known. It seems to me possible that Bell's Antedon wilsoni, which I have never seen, and my Himerometra padophora are the same species, but I am perfectly sure the latter is not a Ptilometra and has no near relationship to that genus. It is. to be hoped that some Australian zoologist will before long investigate carefully the life history of the comatulids, so accessible from Sydney or Melbourne.

Locs.-Eleven miles east-south-east of Clarence River mouth, New South Wales, 35-36 fathoms.

Eight miles east of Sandon Bluffs, New South Wales, 35-40 fathoms.

Six miles east of Cape Hawke, New South Wales, 47-50. fathoms.

Between Port Stephens and Neweastle, New South Wales, 22-60 fathoms.

Shoalhaven Bight, New South Wales, 15-45 fathoms.

South-eastern coast of Australia.

Genus Cosmiometra, A. H. Clark.

Cosmometra DASYBRACHIA, ${ }^{1} s p$. nov.

(Plate IV., fig. 2.)

Arms 20, about $90 \mathrm{~mm}$. long. Centrodorsal about $4 \mathrm{~mm}$. high and scarcely $5 \mathrm{~mm}$. in diameter at base, markedly

1. $\delta a \sigma v^{\prime}=$ rough, downy $+\beta p a \chi^{i} \omega \nu=$ the $\mathrm{arm}$, in reference to the fine roughness of the arms, distally. 
conical ; cirrus-sockets in ten vertical series of 3 or 4 each (about 35 altogether), the series separated radially by a rather broad area, with finely roughened surface. Cirri 45 to $50 \mathrm{~mm}$. long, with 68-74 segments, of which the fifth or sixth is longest (much longer than thick) and all but the basal fifteen have the distal dorsal margin produced into what looks like a sharp spine, when seen from the side; distal segments, including this dorsal spine twice as wide as high.

Radials completely concealed except for the small distolateral corner which appears in the interradial angles of the calyx. IBrl crescentic, the proximal margin strongly convex, the distal correspondingly concave ; excepting only the distal median portion, the whole surface is rough and spinulose, especially the lateral margins. IBr2 (axillary), rhomboidal with anterior margins, slightly concave; all margins finely serrulate and lateral surfaces rough and spinulose; synarthrial tubercle of 1 and 2 , smooth and rounded, low but distinct. IIBr series, 2, very similar to the $\mathrm{IBr}$ series, but the lateral spinulose surfaces are much less marked, especially on the axillary and are nearly wanting on the inner side. First two brachials are similar but are relatively much longer and narrower and have no spinulose lateral areas, though the lateral margins are very serrulate and rough. The division series and these two brachials have strongly flattened sides; the division series are in closely appressed contact, but the lower brachials are much less so, and probably in life hardly touch. Brachials 3-10 quadrilateral, but subsequent segments become triangular, the distolateral angle being more and more prominent; beyond the middle of the arm the segments become quadrilateral again and nearly as long as wide; proximally both proximal and distal margins are everted and rough, but beyond the 12-14 joint only the distal margin is conspicuous ; even near the tip of the arm, however, the distal margin is not very flaring and it never overlaps the following segment. Beginning at the 35 th, or thereabouts, the distal dorsal surface of each segment is rough with minute spines and these soon cover the whole median area of the arm; near the tip, this area is a very narrow band.

$\mathrm{P}_{1}$ about $11 \mathrm{~mm}$. long, of 25 smooth segments, the six basal ones much wider than long, somewhat axe-head shaped, much flattened dorsally; remaining segments longer than wide, or at least as long, the eighth segment being the longest. $\mathrm{P}_{2}$ similar, but only $10 \mathrm{~mm}$. long and with only 22 segments. $\mathrm{P}_{3}$ similar, but a little shorter. $\mathrm{P}_{\mathbf{4}}-\mathrm{P}_{10}$ more prismatic, only 
5-6 mm. long, with 12-14 segments, which have the distal margins, and a sharp dorsal keel, finely serrulate; remaining pinnules similar, but becoming much more slender, longer (8-10 $\mathrm{mm}$.$) , and with more segments (17-18); the sharp,$ serrate dorsal keel is well-marked. Side and covering plates, highly developed. First syzygy between 3 and 4 ; in eleven arms of one specimen, but in only one arm of the holotype, a second occurs between 5 and 6 , and the third is somewhere in the region between segments 18 and 27 ; in the other arms, the second syzygy is generally not until after the twentieth segment; distally the syzygial interval is at first 6-8, but near the tip of the arm it decreases to 4 or 5 . Colour (in alcohol) yellowish-brown; when dry, the shade is much lighter.

While this species resembles both $C$. komachi and $C$. helene in the general character of the arms, the much more numerous cirrus joints, the longer pinnules and the markedly conical centrodorsal seem to prove it is quite distinct. The genus was not previously known from Australian waters.

Loc.-East of Flinders Island, Bass Strait, 70-100 fathoms. Two specimens.

\section{Family AN'TEDONID王.}

Genus Compsometra, A. H. Clark.

Compsometra incomioda (Bell).

Antedon incommoda, Bell, Ann. Mag. Nat. Hist., (6), ii., 1888, p. 404.

Compsometra incommoda, A. H. Clark, Mem. Austr. Mus., iv., 15, 1911, p. 792.

Loc.-South-east of Flinders Island, South Australia, 37 fathoms. 'T'wo specimens.

\section{Compsometra loveni (Bell).}

Antedon loveni, Bell, Proc. Zool. Soc., 1882, p. 534.

Compsometra loveni, A. H. Clark, Proc. Biol. Soc. Washington, xxi., 1908, p. 131.

None of the specimens of Compsometra are especially noteworthy, but they give added weight to the correctness of Mr. A. H. Clark's opinion that there are two distinct species in the seas of south-eastern Australia. To judge from the present collection, as well as from previous records, $C$. incommoda would seem to be the more southern form, occurring from Port Jackson, New South Wales, southward and westward 
to Flinders Island, South Australia, while $C$. loveni occurs from Port Jackson northward to Claremont Island, Queensland. It is true that $C$. loveni is recorded from Port Phillip, Victoria, but further proof of its occurrence there is desirable. Perhaps the specimen in the British Museum is the victim of a misplaced label or a slip of the pen.

Locs.-Twenty miles north-north-east of Double Island Point, southern Queensland, 30 fathoms. One specimen.

Thirteen miles north by west of Double Island Point, Queensland, 25-26 fathoms. One specimen.

\section{ASTEROIDEA.}

The Starfishes, which the "Endeavour" collected, may fairly be counted as one of the most interesting lots which has been brought together by any one vessel since the "Challenger's" famous voyage. It is not so large as some that have been gathered by the "Albatross," but its value is disproportionate to its size, since it adds so much to our knowledge of the Australian marine fauna, three-fourths of the species taken being remarkable for one reason or another. The collection consists of two hundred and sixty-five specimens representing forty-four species, but fifteen of the species are represented by a single individual each; only four species are represented by more than twenty specimens each and of none are there twenty-five. As a natural consequence there is little opportunity to discuss growth changes or even individual diversity. Of the forty-four species, twenty-one are new to science, four are new to Australia and nineteen were previously known from that continent. But even among these nineteen species, there are a number whose occurrence in the "Endeavour" collection adds important data to our knowledge of their distribution. There is one new genus and several of the new species compel modifications of the diagnoses of the genera in which they are placed. The occurrence of the genera Lonchotaster, Mimaster, Mediaster, Calliaster, Ogmaster, Pteraster, Zoroaster, Pedicellaster and Odinia in Australian waters is of great interest; several of them have not previously been known in that quarter of the globe, and at least three of them are characteristic of the North Atlantic, where all, save Calliaster and Ogmaster occur.

The geographical distribution of the species is of much interest, as it reveals a very marked difference between the eastern, southern and western coasts of the continent. Of 
the forty-four species, one from Lord Howe Island and one from Masthead Island, were not collected by the "Endeavour" but are from shore collections made by naturalists not connected with that vessel. Of the remaining forty-two, twenty-three were taken only in southern Australian waters, that is, south of Lat. $37^{\circ}$ and east of Long. $128^{\circ}$, or in other words, on the coasts of South Australia, Victoria and Tasmania; of these twenty-three, nine were taken in the Great Australian Bight and three, all new to science, only there. There are eleven species from the eastern coast, of which ten were not found south of Port Jackson, while one was found at Shoalhaven Bight; only two of the eleven are new forms, the other nine being well-known species of tropical Australia. Only three species, all previously known, were found on both the eastern and southern coasts. There are four species from the western coast only, north of Cape Naturaliste, all of which are very distinct and highly characteristic forms. Of one species, specimens are present from Western Australia and from Tasmania, but the identity of the two is not perfectly established. There are no species in the "Endeavour" collections represented by specimens from all three coasts, but a few are known with that extensive range, such as Luidia maculata, Coscinasterias calamaria and Allostichaster polyplax; the two latter are distinctly southern species but the Luidia is a tropical form and its occurrence on all sides of the continent is most interesting. Two species, Oreaster gracilis and Anseropoda rosacea occur on both the east and west coasts, but not on the south; like the Luidia they are tropical species. It is probable that Plectaster decanus is a southern species occurring on all three coasts, but the evidence is as yet incomplete.

About one hundred species of Starfish had been recorded from Australia, including Lord Howe Island and Tasmania, prior to 1915, but of these some twenty are of very doubtful authenticity and ten others, while valid species, are of very unlikely occurrence in Australia. The "Endeavour" collections include twenty-five additions to the list, thus making up for most of those which must be stricken from the full list. It may not be out of place to add that the Museum of Comparative Zoology collection contains sixteen additional species from Torres Strait, and we are therefore safe in affirming that more than a hundred valid species of starfish are known from Australian waters, in less than three hundred fathoms. Of these at least seventy, or more than two-thirds, are peculiar to Australia. 
Family LUIDIID Æ.

Genus Luidia, Forbes.

LUIDIA FORFICIFER, Sladen.

Luidia forficifer, Sladen, Chall. Rep., Zool., xxx., 1889, p. 258.

This individual seems to be undoubtedly conspecific with the one taken by the "Thetis" in Newcastle Bight, New South Wales, at about the same depth. Both specimens differ from Sladen's types, which were taken north of Australia, in the absence of the pedicellariæ along the ambulacral furrows; in the New South Wales material, the pedicellariæ occur only close to the mouth. It is possible that more and better material will show this difference to be quite inconstant, but on the other hand, direct comparison of specimens from the northern coast of Australia with specimens from the south-east coast may demonstrate that they represent two distinct species.

Loc.-Six miles east of Sandon Bluffs, New South Wales, 35-40 fathoms.

Luidia maculata, Müller and Troschel.

(Plate V.)

Luidia maculata, Müller and Troschel, Sys. d. Ast., 1842, p. 77.

The occurrence of this East Indian species in the Great Australian Bight is particularly noteworthy. All of the six specimens have seven rays.

Locs.--East of Fraser Island, Queensland, 25-30 fathoms.

Eight miles east of Sandon Bluffs, New South Wales, 35-40 fathoms.

South-east of Flinders Island, South Australia, 37 fathoms.

Family ASTROPECTINIDE.

Genus Astropecten, Gray.

Astropecten pectinatus, Sladen.

Astropecten pectinatus, Sladen, Journ. Linn. Soc., Zool., xvii., 1883, p. 251.

Most of these twenty-one specimens are large adults (largest with $R=125 \mathrm{~mm}$.) but half a dozen are still immature, with $R$ only 35-40 $\mathrm{mm}$. There are no specimens of intermediate size. In colour there is considerable diversity; the specimens from 
Oyster Bay, Tasmania, are uniformly gray, those from the south coast of Australia are pale yellow, about half the adults are pale fawn-colour, and the remaining specimens are redbrown. Both the "Thetis" and the "Endeavour" collections show that this is a common and widely distributed species, apparently characteristic of south-eastern Australia. The careful working out of its growth changes would be of the greatest value to students of starfishes, as it would throw much light on the validity of specific characters in the large, cosmopolitan genus to which it belongs. It is to be hoped that some Australian zoologist will soon undertake the work.

Locs.-Eighteen miles south-west of Lady Elliott Island, Queensland, 18 fathoms.

Eleven miles south by east of Ballina, New South Wales, 27-28 fathoms.

Six miles east of Sandon Bluffs, New South Wales, 35-40 fathoms.

Shoalhaven Bight, New South Wales, 15-45 fathoms.

Oyster Bay, Tasmania.

Southern coast of Australia.

Great Australian Bight, 80-120 fathoms.

\section{AstropeCten PREISSII, Müller and Troschel.}

Astropecten preissii, Müller and Troschel, Arch. f. Naturg., ix. i., 1843 , p. 119.

Four of the rays in this individual are regenerating, while the fifth is broken in two ; the latter, however, has no part lacking, and measures $150 \mathrm{~mm}$. in length. Since $r=0$ only 20 mm., $R=7 \frac{1}{2} r$, whereas in Müller and Troschel's type $R=5 \frac{1}{2} r$. In other particulars, however, this specimen agrees well with Müller and Troschel's description, and since their type is said. to have come from south-western Australia, it seems best to refer this individual to their species.

Loc.- -South-east of Flinders Island, South Australia, 37 fathoms.

Genus Lonchotaster, Sladen.

LONCHOTASTER MAGNIFICUS, ${ }^{1} s p$. nov.

(Plate VI., fig. 1-2.)

$\mathrm{R}=155 \mathrm{~mm}$.; $\mathrm{r}=50 \mathrm{~mm}$.; $\mathrm{R}=3 \mathrm{r} . \quad \mathrm{Br}=45-50 \mathrm{~mm}$.; $\mathrm{R}=3-3.5 \mathrm{br}$. Disk very large, flattened but elevated in the central area and along the radii ; rays broad, flat, tapering

1. Magnificus=superb ; in reference to its notable size and appearance. 
uniformly to a blunt point. Disk and rays, within area bounded by superomarginal plates, covered by small (little exceeding $1 \mathrm{~mm}$. in diameter of the slightly capitate top), crowded paxillæ, each of which bears numerous (50-100) short, slender, delicate, somewhat glassy spinelets; paxillæ without definite arrangement, except along sides of rays, where series parallel to the width-diameter of the superomarginal plates may be distinguished; there are usually 2, but may be 3 such series adjoining each superomarginal plate. Madreporic body very large, $14 \mathrm{~mm}$. across, carrying about 50 paxillæ which tend to conceal it very completely; these paxillæ are lower and less perfectly formed than those on the disk itself; the outer margin of the madreporite is $9 \mathrm{~mm}$. from the inner margin of the superomarginal plates. The latter are 46 or 47 in number on each side of each ray; those near the interradial angle are about $2 \mathrm{~mm}$. long by $6 \mathrm{~mm}$. wide, but as one passes distally length increases and breadth decreases and near the middle of the arm they are $3 \mathrm{~mm}$. long and $4 \mathrm{~mm}$. wide; the length never quite equals the width; all of the superomarginals are densely covered by minute spinelets like those of the paxillæ; there are no spines or enlarged spinelets anywhere on the abactinal surface. Terminal plate small, slightly swollen, smooth, pentagonalcordate, with rounded angles.

Inferomarginals correspond in number and position with the superomarginals but are much larger and project conspicuously beyond them, except near tip of ray; the interradial ones are $2 \mathrm{~mm}$. long by $9 \mathrm{~mm}$. wide, while those near the middle of the arm are $3 \mathrm{~mm}$. by $6 \mathrm{~mm}$. ; their covering consists of a close coat of short, flattened, blunt spinelets, much coarser than those on the superomarginals. Fasciolar channels between marginal plates neither peculiar nor conspicuous. Actinal intermediate plates wanting at tip of ray; the series adjoining the adambulacrals begins at about the tenth inferomarginal from tip; a second series begins at about the 17th-20th inferomarginal from tip; a third at about the 30 th ; the last becomes irregular and difficult to follow before reaching the mouth. The remainder of the large, actinal interradial areas are covered by similar but smaller plates forming parallel, radial series between adambulacral and inferomarginal plates ; these radial series are fairly regular ; usually a distinct unpaired series of about 5 plates occupies the midradial lines, but reaches little more than half-way to the inferomarginals. All the actinal plates are covered, like the inferomarginals, with short, flattened, rough spinelets, wider and blunter on central area of each plate than along its margins. There are no spines or enlarged spinelets anywhere. 
Adambulacrals about 57 on each side of each furrow, distinctly longer than wide, except near arm-tips ; furrow margin with 8 conspicuous spines, the adoral and aboral ones being distinctly smallest, the others about $3 \mathrm{~mm}$. long; outside of this series is a well-spaced line of 3-5 shorter and more slender spines and external to them is an irregular line of 4-6 small, slender spinelets; a few extra spinelets may occur on the outer corners of the plates, but there is no tendency to form pedicellarial groups. No pedicellariæ are to be seen. Oral plates large, swollen, covered by flattened spinelets similar to those on the actinal plates, but distinctly larger ; oral spines coarse and heavy, but neither number nor arrangement is peculiar. Colour, light dirty grayish, more or less yellow on various irregular areas.

This individual is much larger than either of the species, collected by the "Challenger," and for which the genus was established, is known to be, and it is not impossible that it will prove to be an adult specimen of $L$. forcipifer, which was taken south of Australia in 1950 fathoms. This seems to me highly improbable, however, for the difference in the form, in the paxillæ and in the matter of pedicellariæ are very marked. Nevertheless I think there can be little doubt that the two forms are congeneric.

Loc.-Great Australian Bight, 80-120 fathoms.

Genus Psilaster, Sladen.

Psilaster acuminatus, Sladen.

Psilaster acuminatus, Sladen, Chall. Rep., Zool., xxx., 1889, p. 225.

Except in size, these four specimens show little diversity; in the smallest $R=42 \mathrm{~mm}$; in the largest $R=100 \mathrm{~mm}$. The actinal interbrachial areas differ considerably in size in the different specimens; in the one from the Eastern Slope, Bass Strait, they are relatively much larger than in Sladen's figure, which answers well for the other specimens. All four individuals are somewhat rubbed, and the two largest are in rather poor condition; in none do I find any trace of spines on the superomarginal plates.

Locs.-Eastern Slope, Bass Strait, 80-200 fathoms.

South of Gabo Island, Victoria, 200 fathoms.

Great Australian Bight, 80-120 fathoms. 
SEA LILIES, STARFISHES, ETC.-CLARK.

Family GONIASTERID $\mathrm{E}$.

Genus Mmaster, Sladen.

Mimaster gracilis, ${ }^{1} s p$. nov.

(Plate VII., fig. 1-2.)

$\mathrm{R}=60 \mathrm{~mm}$. ; $\mathrm{r}=18 \mathrm{~mm}$. ; $\mathrm{R}=3.3 \mathrm{r} . \quad \mathrm{Br}=18 \mathrm{~mm}$.; $\mathrm{R}=3.2 \mathrm{br}$. $\mathrm{Br}$ at middle of ray, $8 \mathrm{~mm}$.; at tip, $3 \mathrm{~mm}$. Disk large, very flat in holotype, but much thicker and more elevated in other specimens; rays narrowing rapidly from the rather broad base, at first flattened but more or less cylindrical near tip. Abactinal surface of disk and rays covered by rounded or substellate plates, which, near centre of disk and along the radial lines are quite closely crowded; each plate bears a paxilla crowned with 10-12 (or more) slender spinelets exceeding the length of the paxilla stalk; the appearance of preserved specimens abactinally depends primarily on whether these spinelets were drawn together into a cylindrical bundle on each paxilla, when the starfish died, or whether they remained more or less flaring; the spinelets are so delicate, they are frequently more or less broken. Miadreporic body large, about $5 \mathrm{~mm}$. in diameter, fully exposed; its distal margin is about $2 \mathrm{~mm}$. from the superomarginal plates. The latter are 50 or more in number, very small, scarcely larger than some of the abactinal plates; each carries an ordinary paxilla. As a rule, they are above and opposite corresponding inferomarginals but here and there they alternate with them; often the series is not easy to distinguish. In a small specimen, $R=27 \mathrm{~mm}$., the superomarginals are relatively much larger; partisularly in the interbrachial are they are well-marked oblong plates, longer than wide, and forming a very regular series. Terminal plate moderate, roughly dumb-bell shaped, being deeply notched both distally and proximally; apparently, in life, it is covered by minute spinelets, but in the preserved specimens, except the youngest, these are all rubbed off.

Inferomarginals of about the same number as superomarginals or somewhat fewer, larger and forming a more perfect series; their paxillæ are larger and carry longer spinelets, but they are by no means conspicuous. Actinal intermediate plates wanting at tip of ray ; the series adjoining the adambulacrals begins at about the tenth inferomarginal plate from tip; a second series begins at about the seventeenth plate and a third at about the twenty-second; at the

1. Gracilis=slender; in reference to the very narrow rays. 
base of the ray there are 8 such series. Actinal interradial areas large, covered by the transverse series of squarish, scarcely overlapping plates; these plates have the paxilla stalk reduced to an oval knob, but the spinelets are long, numerous and flaring. Adambulacral plates more than 70, wider than long; those nearest the mouth are about $2 \mathrm{~mm}$. wide by a millimeter long; furrow margin with 3 , or usually 4, slender, blunt, somewhat flattened spines of which the middle one or two are longest and may be $2 \mathrm{~mm}$. long; outside of this series are three or four parallel series of similar but smaller spines: the whole plate is thus fairly well covered by 15-20 spines, the marginal ones largest, the outermost like those on the actinal plates. There are no pedicellarix. Oral plates conspicuous, swollen; each bears a curved ridge $5 \mathrm{~mm}$. long, carrying a double series of spines; these ridges lie with concave surfaces together, so that although in contact distally and proximally, they are well separated at the middle ; the spines at the distal end are like the spines on the actinal plates but become longer and stouter proximally and at the tip of the jaw are larger than any of the adambulacral spines. Colour, light yellowish-brown or dirty yellowish. Five specimens.

The previously known species of this genus are from the North Atlantic, from the Pacific, west of the southern point of America, and from the Moluccas. The discovery of this fourth species south-east of Australia is therefore of great interest. There is little reason to doubt that it is a Mimaster, but it is easily distinguished from the previously known species by the shape of the rays, and by the adambulacral armature. In the appearance and position of the madreporic body, the Australian species resembles $\boldsymbol{M}$. cognatus, the South American species; in the North Atlantic species $M$. tizardi, the madreporic body is concealed by paxillæ. The genus is a perplexing one and its real relationships are still obscure.

Locs.-South of Gabo Island, Victoria, 200 fathoms. This specimen has been selected as the holotype.

Between Gabo Island, Victoria, and Disaster Bay, New South Wales, 50-100 fathoms.

\section{Genus Nectria, Gray. \\ Nectria ocellata, Perrier.}

Nectria ocellata, Perrier, Arch. de Zool. exp. et gén., v., 1876, p. 4.

This is a nice series of twenty-two specimens, the smallest having $R=17 \mathrm{~mm}$. and the largest, $P=130 \mathrm{~mm}$. In the latter 
$\mathrm{r}=35 \mathrm{~mm}$. and $\mathrm{br}=40 \mathrm{~mm}$. Comparison of these two specimens brings out the interesting fact that there is almost no increase, during growth, in the number of the big paxilliform ossicles; in the small specimen there are 7 in the midradial line of each arm, and about 8 in each interradial area; the whole dorsal surface is almost completely covered by them. In the big specimen, there are only 7 or 8 well formed ones on each radial line, while in the interradial areas the number is not more than 8 or 10 ; along the sides of the basal part of each ray new ones have formed, but they are smaller than the others and merge into the ordinary abactinal plates. But in the large specimen, the ossicles are widely separated from each other, the abactinal skeleton and papular areas being fully exposed. In the small specimen, there are only 12 marginal plates in each series on each ray; they are closely joined with no trace of intermarginal papulæ. Even in the large specimen, however, I fail to find any intermarginal papulæ.

Locs.-North-east of Cape Pillar, Tasmania, 55-80 fathoms. Oyster Bay, Tasmania, 60 fathoms.

Off Babel Island, Bass Strait, 50-60 fathoms.

Between Davenport and Launceston, Tasmania.

Forty miles west of Kingston, South Australia, 30 fathoms.

Great Australian Bight, 80-120 fathoms.

\section{NeCtria OCELlifera (Lamarck).}

Asterias ocellifera, Lamarck, Anim. sans Vert., ii., 1816, p. 553 .

Nectria ocellifera, Gray, Ann. Mag. Nat. Hist., vi., 1840, p. 287 (oculifera, lap. cal.).

These five specimens are probably from the same lot as those in the Western Australian Museum at Perth, by means of which it was possible to clear up the difference between $N$. ocellata and $N$. ocellifera. ${ }^{1}$ There can be no doubt, I think, that the two species are perfectly distinct, and the "Endeavour" collections seem to confirm the view that their areas of distribution do not overlap. The specimens of $N$. ocellifera at hand are all small, having $R$ only about $40 \mathrm{~mm}$.

Loc-Between Geraldton and Cape Naturaliste, Western Australia.

1. H. L. Clark-Rec. West Austr. Mus., i., 1914, p. 139. 
Genus Nymphaster, Sladen.

As regards the generic name, it is to be regretted that Koehler still persists in using Dorigona in place of $\mathbf{X}$ ymphaster. Sladen, in 1889, Verrill, in 1899, and Fisher more recently, have pointed out that Dorigona is not one of Perrier's genera, but dates back to Gray. Its type is either $D$. reevesii, Gray or $D$. longimana (Möbius); no other species can be the type since these are the only species mentioned by Gray, who, however, designated no type. It has been shown, and, so far as I know, never questioned, that $D$. reevesii, Gray is synonymous with Goniodiscus capella, Müller and Troschel, 1842. Now von Martens constituted a subgenus, Ogmaster, for $G$. capella in 1865, a year before Gray proposed Dorigona. All later writers have agreed that $G$. capella is entitled to generic rank and, including Koehler himself, use Ogmaster capella as the correct combination. Hence Dorigona longimana (Möbius) must be the type of Dorigona, and I am quite unable to see why Sladen should have deliberately replaced Gray's name with one of his own coining, Iconaster. So far as I can see Iconaster is a pure synonym of Dorigona, which is a monotypic genus with Astrogonium longimanum, Möbius, as its type.

It is evident then that Nymphaster and Dorigona are not in any way equivalent terms. Koehler proposes to restrict $\mathrm{Nym}$ phaster to the forms in which the superomarginal plates are separated by a single median row of abactinal plates and use Dorigona for the forms in which the superomarginal plates are in contact dorsally. It is, of course, obvious that Dorigona cannot be used in any such way. Moreover Verrill, in 1899, proposed Nereidaster for the species with separated superomarginals, and restricted Nymphaster to the species which Koehler would call Dorigona. This he was perfectly justified in doing, for Sladen designated no type for the genus in which he included five species. Clearly Dorigona, Koehler, is a perfect synonym of Sladen's Nymphaster as restricted by Verrill, and has no close relationship to Dorigona, Gray. It is to be hoped, therefore, that our able and honoured French colleague will no longer reject Nymphaster and will confine Dorigona to Möbius' remarkable species.

Nymphaster PENTAgONUS, ${ }^{1} s p$. nov.

(Plate VIII., fig. 1-2.)

$\mathrm{R}=60 \mathrm{~mm}$. or thereabouts ; $\mathrm{r}=18 \mathrm{~mm}$.; $\mathrm{R}=3.3 \mathrm{r}$. $\mathrm{Br}=$ $10 \mathrm{~mm}$. : $\mathrm{R}=6 \mathrm{br}$. Br at middle of ray, $6 \mathrm{~mm}$. ; at tin,

1. Pentagonus = with five angles, or, as usually understood, five-sided; in reference to the nearly straight-sided area of abactinal plates. 
apparently about $2 \mathrm{~mm}$. Breadth at proximal margin of first superomarginals which meet=length of first three superomarginals (counting from interradius). Disk flat, rather large ; rays moderately long and quite narrow, all broken at tip, but one seems to be nearly complete, quadrangular in cross-section with very slightly rounded angles, the width :slightly exceeding the thickness, at all points. Abactinal plates entirely confined to disk, forming an almost perfectly pentagonal area, the sides of which are so slightly concave as to appear almost straight; there are $650-700$ plates in this area but most of these are very small and lie along the boundaries formed by the superomarginal plates; the largest abactinal plates are near the centre of the disk in the interradii and along the midradial lines. At the centre of the disk and in the radial areas where the papulæ occur, the plates are more or less stellate or substellate basally, the upper surface being rounded pentagonal or subcircular; each plate carries 15-25 coarse granules, nearly spherical and not at all rough, those of the marginal circle not being appreciably different from the rest; near the superomarginal plates, the abactinal plates are so small and crowded, the granules tend to form a continuous coat with those on the superomarginals. The latter are apparently rather more than 20 on each side of each ray, and excepting the basal 4 pairs are in complete contact in the midradial line; they are very flat, not at all tumid, and in the interbrachial arcs overhang the inferomarginals ; eight superomarginals make up each side of the disk-pentagon; they are wider than long, the middle pair being each $5 \mathrm{~mm}$. wide by $2.5 \mathrm{~mm}$. long; at the middle of the arm the superomarginals are each about $2 \mathrm{~mm}$. long, $2 \mathrm{~mm}$. wide, and $1.5 \mathrm{~mm}$. thick; all the superomarginals are covered by a uniform coating of granules similar to those on the abactinal plates; these are largely rubbed off in the present specimen; on the entire surface of each of the middle pair of superomarginals, there are about 200 granules.

Inferomarginals coincide in number and position with the superomarginals (except when regeneration has occurred), but owing to the presence of the ambulacral groove they are much narrower ; at the middle of the arm they are about $2 \mathrm{~mm}$. long, $1 \mathrm{~mm}$. wide and $1 \mathrm{~mm}$. thick; like the superomarginals, they are clothed with a close coat of granules, each one of the middle pair carrying about 150 . Actinal intermediate plates wanting on rays; the series adjoining the adambulacral plates, extends only to the fourth inferomarginal and contains 10-12 plates; outside of it is a series of 6-8 plates, then a series of 5-6, then 
a series of 2 or 3 , and then a single plate, against the inferomarginals, completes the covering of the area ; all these plates. tend to overlap inwardly and proximally; all are learers of granules like those on the inferomarginal plates. Adambulacral plates about 40 , at first wider than long, but rapidly decreasing in breadth and becoming twice as long as wide ; distal to middle of arm there are about 7 adambulacrals to about 5 inferomarginals; the furrow margin is at first nearly straight, but soon becomes convex and then the convexity becomes more and definitely restricted to the adoral end; distal to the middle of the arm, these convexities on plates of opposite sides tend to meet across the furrow, the bridges thus formed alternating with conspicuous pores where the plates are not in contact; proximally there are 6 or 7 blunt, somewhat angular, more or less flattened spines, about half a millimeter long on the furrow margin of each plate; the middle spines are longest, the proximal and distal shortest; on the plates distal to arm-middle there may be 8 or 9 spines in the series, but they are decidedly shorter; outside the marginal series is a parallel set of $3-5$ much smaller, thicker spines or high granules, and external to it a parallel series of 5-6 granules like those on the actinal plates; additional similar granules may occur between the two external series or outside the outer one ; the adambulacrals may thus be about as well covered with granules as any of the actinal plates. Oral plates neither conspicuous nor peculiar, only the proximal spines enlarged and they not very greatly. Pedicellariæe none. Colour gray, more yellow beneath; nearly white where the granules are rubbed off.

The markedly pentagonal abactinal area, the flat and overhanging interradial superomarginals, the adambulacral armature and the general proportions remind one very strongly of $N$. albidus, from the tropical Atlantic, but the adambulacral spines are angular and flattened in the Australian species and eight superomarginal plates, instead of six, make up the disk boundary on each side. None of the species from the Indian Ocean and Philippine Islands seem to be any nearer than $N$. albidus to this South Australian species.

Loc.-Great Australian Bight, $129^{\circ} 28^{\prime}$ E., 250-450 fathoms. One specimen. 
SEA LILIES, STARFISHES, ETC.-CLARK.

Genus Mediaster, Stimpson.

Mediaster aUstraliensis, ${ }^{1} s p$. nov.

(Plate ix., fig. 1-2 ; Fig. 1-3.)

$\mathrm{R}=82 \mathrm{~mm}$. ; $\mathrm{r}=30 \mathrm{~mm}$.; $\mathrm{R}=2.67 \mathrm{r} . \mathrm{Br}=30 \mathrm{~mm}$.; $\mathrm{R}=2.67 \mathrm{br}$. $\quad$ Br at middle of ray $=11 \mathrm{~mm}$. ; at tip, $2.3 \mathrm{~mm}$. In the largest specimen, $R=100$ and $r=40 \mathrm{~mm}$. Disk large and flat; arms wide at base but tapering rapidly to a nearly cylindrical tip. Abactinal plates tabulate, more or less paxilliform (Fig. 1) especially at centre of disk and along midradial

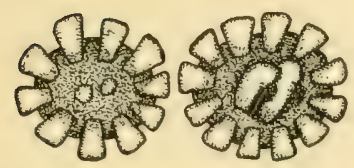

Fig. 1.x10. Fig. 2.x10.

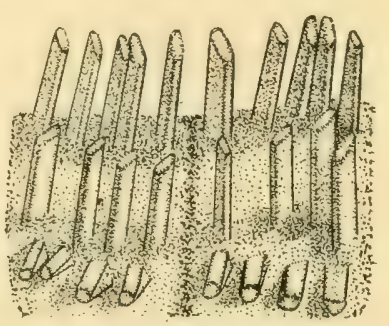

Fig. 3.x10.

lines; small and numerous; the largest and most paxilliform are crowned with a marginal series of 12-15 angular, blunt spinelets or coarse granules and within this circle 3-8 similar but smaller granules; the smallest and least paxilliform plates adjoin the superomarginals in the interradial areas and are crowned with a little group of 3-5 angular granules; the coarseness or fineness of the paxillar granules shows great diversity in different individuals and even in different parts of the same disk; thus in one specimen, plates proximal to the madreporite carry 10-20 coarse, well-spaced granules, while plates of the same size, distal to the madreporite, carry 25-40 smaller, more rounded and more crowded granules. Occasionally one or more of the granules is replaced by a 2 -jawed pedicellaria ; in the holotype, these pedicellarix are very numerous and are so much higher than the granules (about twice as high), that they are quite conspicuous; they are also quite symmetrical and frequently entirely replace the granules on the top of the plate (Fig. 2); in other specimens, pedicellariæ are exceedingly rare, while in still others, though common, they are small and

1. Australiatensis, expressing locality. 
asymmetrical; they occasionally replace one or more of the maryinal granules. Papule numerous, small, single, occurring scattered more or less irregularly among the plates; occasionally a regular series of 6 surrounds a large plate. Nadreporite small, about equal to 2 or 3 ordinary abactinal plates, rounded triangular, only half as far from centre of disk as from disk margin.

Superomarginal plates about 40 on each side of each ray (48 in the largest specimen), those in interradial region nearly twice as wide as long, more nearly square at middle of arm and then becoming much wider than long again near tip; all are closely covered with granules, similar to but more rounded, and the marginal ones at least, distinctly coarser, than those on the largest abactinal plates; there are about 100 on each of the superomarginals near the interradius; occasionally pedicellarise replace granules. Terminal plates small, distinctly longer than wide, not deeply notched distally. Infero marginals apparently one less on each side of each ray than superomarginals, at least in the larger specimens ; the number may be the same in the two series, but in many cases the series do not correspond exactly along the middle of the arm; the granular covering of the inferomarginals is like that of the other series. Actinolateral plates in 8-9 series; the first (adjoining the adambulacrals) extends from the oral plates to the tenth inferomarginal from the tip of the arm; the next series extends to the twentieth inferomarginal from arm-tip ; the next series only reaches the eighth or ninth inferomarginal, counting from interradial mid-line ; remaining series irregular and of few small plates; all the plates carry coarse, angular granules like those on the abactinal plates, but no pedicellariæ occur; at least I have seen none. Adambulacral plates squarish or rather wider than long, about 60 (in the holotype), the inner margin at first straicht but becoming decidedly convex distally; furrow margin with a series of 5 or 6 flat, blunt spines, rather crowded, nearly equal or the most adoral shortest (in the figure [Fig. 3] the spines are too abruptly truncate and are too widely spaced) ; externally is a second series of 4 shorter, thicker, more angular spines; a third series of 3 or 4 still shorter and thicker spines are borne on the outer margin of the plate; between this series and the second is a rather conspicuous bare space; the spines of the third series are scarcely to be distinguished from the angular granules on the actinolateral plates. Oral plates neither conspicuous nor peculiar; the oral spines, especially at tip of jaw, are, however, very heavy, more or less prismatic and $2-3 \mathrm{~mm}$. long. Colour, 
in alcohol, brownish-yellow; dry, pale brown. Seven specimens.

This fine species is obviously near to Mediaster ornatus, Fisher, from the Hawaiian Islands, but differs in the wider, shorter marginal plates and in the adambulacral armature. No other member of the genus is very closely allied. As regards the internal anatomy, the Australian species is a typical Mediaster, the internal abactinal ossicles being very evident and rudimentary superambulacral plates also being present.

Locs.-East coast of Flinders Island, Bass Strait, 40 fathoms. This specimen has been selected as the holotype.

East of Babel Island, Bass Strait, 65-70 fathoms.

Oyster Bay, Tasmania.

\section{Mediaster monacanthus, ${ }^{1} s p$. nov.}

$$
\text { (Plate x., fig. 1-2; Fig. 4.) }
$$

$\mathrm{R}=110 \mathrm{~mm}$.; $\mathrm{r}=37 \mathrm{~mm}$. ; $\mathrm{R}=3 \mathrm{r} . \quad \mathrm{Br}=37 \mathrm{~mm}$; $\mathrm{R}=$ $3 \mathrm{br}$. Br at middle of ray $=19 \mathrm{~mm}$.; at tip $=5 \mathrm{~mm}$. Disk large, flattened or slightly elevated; arms wide at base, tapering rather evenly to the blunt tip. Abactinal plates on dise and base of rays large, low, hemispherical, widely spaced, becoming smaller and more and more crowded near the superomarginals; they are connected with each other by heavy radiating ossicles, in the spaces between which the papulæ arise in groups of 3-15. Each plate is covered by a coat of low, spherical granules; there are about 50-75 on a plate 4-5 $\mathrm{mm}$. in diameter ; there are no granules on the membrane or on the ossicles between the plates. In the holotype, and some other specimens, most of the disk plates bear at the centre a pointed tubercle or low, blunt spine, about a millimeter in diameter and nearly or quite as high; in some specimens few or no plates have this spine, so it may be an indication of complete maturity. Distally on the rays and near the margins of the disk, the plates become smaller and crowded, so the granular covering is nearly or quite continuous. Madreporite very small, only about $2 \mathrm{~mm}$. across, situated twice as far from the margin as from centre of disk. Anus conspicuous near centre of disk because surrounded by $10-20$ large, smooth, elongated granules of diverse size and shape.

1. $\mu o_{\nu}=$ single $+u_{\kappa} \alpha \nu \theta a=$ a thorn or spine; in reference to the single prominent spine on some abactinal plates. 
Superomarginal plates nearly or quite vertical in position, and hence scarcely to be seen from above, 30-32 in number, the interradial ones much higher than long, covered with granules similar to those on the abactinal plates; there are about 200 granules on one of the big interradial superomarginals. Terminal plate small, nearly circular, considerably swollen. Inferomarginals very similar to superomarginals in number, position, size and form ; they have the same granular covering. In the holotype and in some other specimens intermarginal plates of irregular size, shape and position occur in considerable numbers, but this is not a constant feature, since in some individuals such plates appear to be rare if not altogether wanting. Actinolateral plates in about 7 series ; the first, adjoining the adambulacrals, extends nearly or quite to the arm-tip, the second goes about the three-fourths of the way, and the third more than half; all the actinolateral plates are covered by granules distinctly coarser than those on the abactinal surface.

Adambulacral plates about 60 , longer than wide, with a fairly straight margin; on this margin is a series of 4 subequal, squarish, blunt spines, about $2 \mathrm{~mm}$. long (occasionally a fifth, adoral, much smaller spine occurs); outside this: series is a second, consisting of 3 or 4 shorter, but thicker spines, and external to these is a series of 4 much smaller

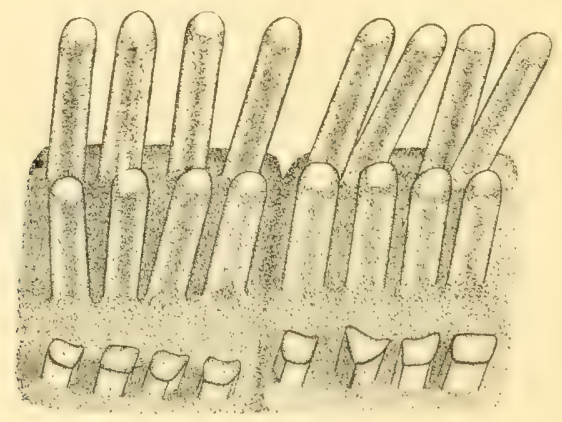

Fig. 4.x10.

spines or angular granules, which do not much exceed the granules on the actinal plates. Oral plates not conspicuous. or peculiar; even the oral spines are not strikingly larger than those on the adjoining adambulacrals. No pedicellariæ were detected anywhere. 
Colour (dry or in alcohol), brown, darkest on the bare membrane of the disk, lightest near the tips of the rays.

This is a very remarkable Starfish, one of the most interesting of the "Endeavour's" captures. It stands midway between Nectria and Mediaster having the heavy, widely separated abactinal plates of the former, but with these plates not at all paxilliform. It is very different from typical Mediaster in its general appearance abactinally, but actinally is very similar to $M$. australiensis, save that the spines and granules are much coarser. Supplementary internal abactinal plates and rudimentary superambulacrals are present. The ampullæ are double. It might be made the type of a new genus between Mediaster and Nectria but there are already so many monotypic genera, one may well be avoided here, since the diagnosis of Mediaster, as at present used, does not require any essential modification to admit $M$. monacanthus. This specific name is not altogether a happy choice, since many specimens fail to show the single spinelet on the abactinal plates, so conspicuous in the holotype ; but as the name has been in vogue as a manuscript name for several years, and specimens so labelled have been sent out from Sydney, it seems best to retain it. It is a little remarkable that this conspicuous Starfish was taken at only one station. Ten specimens.

Loc.-Six miles east of Cape Hawke, New South Wales, 47-50 fathoms.

\section{Genus Tosia, Gray.}

Tosia aurata, Gray.

Tosia aurata, Gray, Proc. Zool. Soc., 1847, p. 80 .

This is a fine series of this handsome pentagonasterid; the longest has $R=73$; in the smallest $R=40$; in the least pentagonal $\mathrm{r}=.60 \mathrm{R}$, and in the most pentagonal, $\mathrm{r}=.68 \mathrm{R}$. One of the specimens from Oyster Bay, Tasmania, with $\mathrm{R}=63$ $\mathrm{mm}$. is perfectly tetramerous. Eighteen specimens.

Locs.-Oyster Bay, Tasmania, 20-40 fathoms.

Isle de Phoque, Oyster Bay, Tasmania, 27 fathoms.

Mainwaring Cove, west coast of Tasmania, 50 fathoms.

South-east coast of South Australia.

South coast of South Australia. 


\section{Genus Pentagonaster, Gray.} Pentagonaster stibarus, H. L. Clark.

Pentagonaster stibarus, H. L. Clark, Ree. West Austr. Mus., i., 1914, p. 136.

No doubt this specimen was taken with the types; it adds nothing to our knowledge of the species; there are, however, no abactinal tubercles, but $R$ only $=33 \mathrm{~mm}$. By an unfortunate slip of the pen in the original account of this species, in discussing the relative size of the marginal plates in the genus, I wrote superomarginal for inferomarginal, and it is so printed (p. 138, 1. 22), confusing the sentence.

Loc.-Between Geraldton and Cape Naturaliste, Western Australia.

Genus Calliaster, Gray.

Calliaster spinosus, ${ }^{1} s p$. nov.

(Plate xi., fig. 1-2.)

$\mathrm{R}=140 \mathrm{~mm}$. ; $\mathrm{r}=45 \mathrm{~mm}$. $\mathrm{R}=3 \mathrm{r} . \quad \mathrm{Br}=40 \mathrm{~mm} . \mathrm{R}=$ $3.5 \mathrm{br}$. Br at middle of ray, $18 \mathrm{~mm}$.; at tip, $5 \mathrm{~mm}$. Disk large, somewhat elevated at centre and along radii; arms abruptly narrowed and tapering gradually to the blunt tip. Abactinal surface covered by moderately large stellate plates, the central portion of which is swollen into a flattened hemisphere; each of these rounded centres is surrounded by a circle of coarse granules, which more or less conceal the papulæ arising singly between the plates, and is crowned by a group of coarser granules, the central one of which is distinctly the biggest; occasionally, though not commonly, one of these crowning granules is replaced by a large 2 -jawed pedicellaria fitting into a special depression in the surface of the plate; each jaw of the pedicellaria is broadly spatulate, rounded at the tip and, when open, lies back in the depression, so as to seem flush with the surface of the plate. The "crowning " granules differ from the " marginal" granules, not merely in being, as a rule, larger, but in that they are more or less spherical, while the marginal ones are very flat.

Along the midradial line of each ray, there is a series of plates which extend from the terminal plate, which is large and somewhat swollen $(4 \mathrm{~mm}$. long, $3 \mathrm{~mm}$. wide proximally

1. Spinosus=provided with spines; in reference to the spiny actinal surface. 
and $3 \mathrm{~mm}$. thick), to within $15-20 \mathrm{~mm}$. of the centre of the disk; distally these plates are much like the other abactinal plates and are about $2 \mathrm{~mm}$. in diameter; near the middle of the arm and proximal to it they become compressed and are much wider than long $(3-4 \mathrm{~mm}$. wide by $1.5-2 \mathrm{~mm}$. long), but the 4-6 most proximal are again more or less nearly circular; these circular proximal plates are the largest of the disk and are very much swollen; the most proximal, which is largest, is $5-6 \mathrm{~mm}$. in diameter and $3 \mathrm{~mm}$. or more high ; on these big proximal plates, the central granule becomes developed into a huge spine, $2 \mathrm{~mm}$. in diameter; only one of these persists in the specimen at hand; that is on the fourth plate of one of the radial series and measures $3 \mathrm{~mm}$. in height. The median radial plates are accompanied nearly, and sometimes quite, to the terminal plate, by a series of similar, but smaller and less conspicuous plates, without spines. At the centre of the disk, and in each interradius, in line with the most proximal of the big radial plates, are enlarged plates, which apparently bore spines. The circular madreporite, $4 \mathrm{~mm}$. across, lies. just distal to one of these large interradial plates.

Superomarginal plates 25-26 on each side of each ray, more or less bare and smooth, and distinctly swollen; each plate is surrounded by a series of flattened granules; the plates in the interbrachial are bear a vertically elongated cluster of spherical granules, among the lower ones a stout spine ; on the first superomarginal (adjoining the interradial line), this spine is about $6 \mathrm{~mm}$. long and a millimeter thick at base ; each succeeding plate has fewer granules, and the spine becomes stouter and stands nearer to the centre of the plate; at the middle of the arm, the spine may be $2 \mathrm{~mm}$. in diameter and there are virtually no granules on the plate ; distally the spines become steadily smaller; in the present specimen none are left distal to middle of arm; occasionally one, or even two, of the granules on the plate are replaced by the big, characteristic pedicellariæ. Inferomarginal plates one more in number than the superomarginals and hence not corresponding exactly in position, except at each end of the series; very similar in appearance but with more granules (especially at oral end, in interradial are) and (to judge from the single one remaining) with more slender spines.

Actinolateral plates wanting on distal half of ray; the first series (adjoining adambulacrals) begins at about the ninth, or eighth, inferomarginal (counting from interradial line); the second series begins at the third inferomarginal and a third series at the second; the rest of the large actinal area is. 
occupied by about ten similar plates; these plates are more quadrilateral than the abactinal plates and differ in being less swollen, much more completely covered with granules and in having the central granule replaced by a more or less conspicuous spine, 1-5 $\mathrm{mm}$. long, $1-2 \mathrm{~mm}$. in diameter, and bluntly pointed, clavate or chisel-shaped at tip ; these spines are smallest near the inferomarginals and largest near the adoral adambulacrals; the granules are coarser than on the abactinal surface and there is less distinction between "crowning" and " marginal " granules; many granules are replaced by the large, characteristic pedicellariæ. Adambulacrals about 55, wider than long or squarish, quite similar to the actinolaterals in having marginal granules on the adoral, outer and aboral sides, a group or series of somewhat coarser granules on the outer end and a large spine at or near the centre; these spines may exceed $5 \mathrm{~mm}$. in length; on the first two plates (near mouth) and occasionally elsewhere, a second spine, similar but much smaller, stands just behind the large one; on the furrow margin of the plate is a series of 7-8 crowded, compressed, blunt spines of which the four or five middle ones are sub-equal, about $2 \mathrm{~mm}$. long, while the aboral, and the adoral ( 1 or 2 ) are markedly shorter and more pointed ; on the adoral, marginal corner of the plate is a very large pedicellaria, of the same type as those elsewhere, but with jaws of very different shape, 1.5-2 mm. long, slenderly spatulate and slightly asymmetrical, bluntly pointed. Oral plates not particularly large or prominent; each has 7 or 8 large, furrow spines, the proximal ones very large and prismatic; each plate bears on its surface two large spines like those on the adjoining adambulacral plates. Colour (dry), pale yellowish-brown.

This is the most notable and the best characterised of all the "Endeavour's" Starfishes, not previously known to science. The adambulacral armature with big pedicellariæ and the spiny actinal interradial areas distinguish it at once from any other member of the genus, although it seems to be nearest the Philippine species $C$. corynetes, since it has pedicellariæ like those of that species, spines on the actinal plates and an adambulacral armature of the same type. It is readily distinguished from $C$. corynetes, however, by the absence of spines on the terminal plate and by the granulose abactinal plates. The diagnosis of Calliaster as given by Fisher ${ }^{1}$ will require considerable modification to admit this fine new species from Australia (and the Philippine form, too), for

1. Fisher-Bull. U.S. Nat. Mus., Ixxvi., 1911, p. 171. 
there are abactinal pedicellariæ, the plates are not bare centrally and the actinal intermediate plates have very conspicuous spines. The validity and the sharp definition of the genus are not, however, in any way affected.

Loc.-Eastern Slope, Bass Strait, 80-200 fathoms.

Genus Ogmaster, von Martens.

OGMASTER CAPELla (Müller and Troschel).

Goniodiscus capella, Müller and Troschel, Sys. d. Ast., 1842, p. 61 .

Goniaster (Ogmaster) capella, von Martens, Arch. f. Naturg., xxxi. i., 1865, p. 359.

Ogmaster capella, Sladen, Chall. Rep., Zool., xxx., 1889, p. 261.

It is exceedingly interesting to find this little-known East Indian species so far south as North Reef, Queensland.

Loc.-Thirteen miles north-east of North Reef, 70-74 fathoms; thirty-eight miles north-east of North Reef, Capricorn Group, off Port Curtis, Queensland, 50-75 fathoms. Five specimens.

\section{Genus Stellaster, Gray. \\ Stellaster INCEI, Gray.}

(Plate xii., fig. 1-2.)

Stellaster incei, Gray, Proc. Zool. Soc., 1847, p. 76.

About half these specimens are dark brick red, of varying degrees of intensity, while the others are pale brown or dull yellowish; the difference is not associated with locality. Regardless of the ground colour, certain individuals have, in marked contrast, a number of the actinolateral plates, adjoining the adambulacral plates near the mouth, deeply stained with reddish-purple. All the specimens are dry. There is more or less diversity also in the number of tubercles on the abactinal surface, the extremes being 10 and 100 , and their size and arrangement is equally diverse. The largest specimen has R nearly $90 \mathrm{~mm}$. Twenty-three specimens.

Locs.-Thirteen miles north-east of North Reef, Capricorn Group, off Port Curtis, Queensland, 70-74 fathoms.

Wide Bay, Queensland, 18-23 fathoms.

Twenty-five miles south-east of Double Island Point, Queensland, 33 fathoms. 
Eleven miles south by east of Ballina, New South Wales, 27-29 fathoms.

East-south-east of Clarence River mouth, New South Wales, 35-36 fathoms.

\section{Stellaster INSPINOSUS, ${ }^{1} s p$. nov.}

(Plate xiii., fig. 1-2.)

$\mathrm{R}=60$ or $75 \mathrm{~mm}$. ; $\mathrm{r}=23$ or $27 \mathrm{~mm}$. ; $\mathrm{R}=2.6 \mathrm{r}$. Br at middle of ray, 11 or $14 \mathrm{~mm}$. Very similar to $S$. incei, but differing sharply in several features. The marginal plates, though of essentially the same number, encroach more on both surfaces than in $S$. incei; as a result, the median radial series of abactinal plates is accompanied by lateral series only to about the fourth (from interradius) superomarginal and there are practically no papulæ on the distal half of the arm, while in $S$. incei the lateral series extend to about the eighth plate and the papulæ occur far out on the arm; on the lower surface, there are only about 10 actinolateral plates in each area, aside from the series adjoining the adambulacrals, while in $S$. incei there are 12-20. 'T'he pedicellarix on the adambulacral plates are strikingly taller and more slender in $S$. inspinosus than in $S$. incei, while the big actinal spine is much smaller. More important is the fact that there are no spines on the inferomarginal plates, save that on some arms, the fifth (rarely the sixth) inferomarginal has a very small, flat spinelet, about $.75 \mathrm{~mm}$. long, on its outer distal corner. Finally, the granulation is finer in $S$. inspinosus than in $S$. incei and the abactinal tubercles are fewer, 10 in the smaller specimen, but only 2 in the larger. Colour (dry), very pale brown.

This Starfish is of particular interest not merely because it seems to replace $S$. incei on the west coast of Australia, but because it is apparently a connecting link between the genera Stellaster and Ogmaster. Fisher" thinks "there is no particular similarity between Stellaster and Ogmaster," but I am unable to agree with him. Indeed, I should be inclined to say there is no important difference between the two. Ogmaster is only a Stellaster which has lost its spines and granulation, and this new West Australian species, S. inspinosus, is quite intermediate in that

1. Inspinosus =without spines; in reference to the absence of spines of the inferomarginal plates.

2. Fisher-Bull. U.S. Nat. Mus., lxxvi., 1911, p. 169. 
the granulation is finer than in other Stellasters and the marginal spines are gone; the abactinal spines too are much reduced in number and even the actinal, adambulacral spine is somewhat smaller than in other species. If Ogmaster is not a close relative of Stellaster, it is hard to see what its correct position is.

Loc.-Between Geraldton and Cape Naturaliste, Western Australia. Two specimens.

\section{Genus Anthenea, Gray. Anthenea acdta, Perrier.}

Goniodiscus acutus, Perrier, Ann. Sci. Nat., Zool., (5), xii., 1869, p. 280.

Anthenea acuta, Perrier, Arch. de Zool. exp. et gén., v., 1876 , p. 91 .

This is an excellent series, with $R$ ranging from 40 to 120 $\mathrm{mm}$., and the vertical diameter of the disk from 12 to $50 \mathrm{~mm}$. The growth changes are well shown, as well as considerable individual diversity. Twenty-four specimens.

Locs.-Off Fraser Island, Queensland, 32-33 fathoms.

Off the Queensland coast.

Twenty miles north-north-east of Double Island Point, Queensland, 30 fathoms.

Thirteen miles north by west of Double Island Point, Queensland, 25-26 fathoms.

Twenty-five miles south-east of Double Island Point, Queensland, 33 fathoms.

Eleven miles south by east of Ballina, New South Wales, 27-29 fathoms.

Eleven miles east-south-east of Clarence River mouth, New South Wales, 35-40 fathoms.

Eight miles east of Sandon Bluffs, New South Wales, 40 fathoms.

\section{Family OREASTERIDA. \\ Genus Oreaster, Müller and Troschel. \\ OREASTER AUSTRALIS, Lütken.}

Oreaster australis, Lütken, Vid. Med., 1871, pp. 252, 263.

These are all dry adults, illustrating not only the great individual diversity in abactinal spines, but also the diversity caused by differences in collapse and contraction when drying. 
The proportion of $\mathrm{R}$ to $\mathrm{r}$ shows little diversity, ranging only from 2.3 to 2.5. The largest specimen has $R=155 \mathrm{~mm}$.; $\mathrm{r}=60 \mathrm{~mm}$.; br at middle of ray, $30 \mathrm{~mm}$. In colour, these specimens are either tawny brown or deep brick red; one of the red ones has the central abactinal area light yellowishgray in sharp contrast. Sixteen specimens.

Locs.-Eighteen miles south-west by south of Lady Elliott Island, Queensland, 18 fathoms.

Twenty-five miles south-east of Double Island Point, Queensland, 33 fathoms.

\section{Oreaster gracilis, Lütken.}

Oreaster gracilis, Lütken, Vid. Med., 1871, pp. 260, 264.

The fact that this specimen comes from the same station as all but one of the specimens of $O$. australis makes me hesitate to designate it by a different name, yet it is obviously different. $\mathrm{R}=155 \mathrm{~mm}$.; $\mathrm{r}=48 \mathrm{~mm}$.; br at middle of ray $=22 \mathrm{~mm}$. $R=$ $3 \mathrm{r}$. Not only are the rays thus much longer and more slender proportionally than in $O$. australis, but the meshes of the abactinal skeleton are noticeably finer, and hence the papular areas are much smaller. The colour is light yellowish-gray. I think there is no doubt that the specimen is $O$. gracilis but I believe it may ultimately be shown that $O$. gracilis is only a form of $O$. australis, the peculiarities of which are emphasised in drying.

Loc.-Eighteen miles south-west by south of Lady Elliott Island, Queensland, 18 fathoms.

\section{Genus Asterodiscus, Gray.}

\section{Asterodiscus truncatus, Coleman.}

Asterodiscus truncatus, Coleman, Mem. Austr. Mus., iv., 14, 1911, p. 699.

This is a fine series of this notable species, but there is nothing to add to Coleman's careful description, save that the species grows to a size much larger than his types. His holotype has $\mathrm{R}=103 \mathrm{~mm}$., while his figured specimen has $\mathrm{R}=138 \mathrm{~mm}$. The smallest of the "Endeavour" specimens has $R=83$, while the large specimens have $R=150-165 \mathrm{~mm}$. 
It is virtually impossible to distinguish the marginal plates, except partially in the small specimens. In the large specimens papulæ extend over onto the actinal surface. Nine specimens.

Locs.-Six miles east of Cape Hawke, New South Wales, 47-50 fathoms.

Eastern slope, Bass Strait, 80-200 fathoms.

Coast of Victoria.

Great Australian Bight, 80-120 fathoms.

\section{Family LINCKIID $A$.}

\section{Genus Fromia, Gray.}

Fromia polypora, ${ }^{1} s p$. nov.

(Plate xiv., fig. 1-2.)

$\mathrm{R}=86 \mathrm{~mm}$.; $\mathrm{r}=18 \mathrm{~mm} . ; \mathrm{R}=4.7 \mathrm{r} . \quad \mathrm{Br}=19 \mathrm{~mm}$. $\mathrm{R}=$ $4.5 \mathrm{br}$, Br at middle of ray, $14 \mathrm{~mm}$.; at tip, $4 \mathrm{~mm}$. Disk moderately large, not specially flattened; arms more or less flattened, but cylindrical near tip. Whole abactinal surface covered by more or less circular plates about one millimeter in diameter, some larger, some smaller, with no definite arrangement whatever; scattered every where are the numerous rather large, single papulæ; the plates are covered by polygonal, more or less flattened granules, 10-30 to each plate, the marginal ones smallest, the central ones noticeably, but not conspicuously larger. Superomarginal plates about 37, not at all conspicuous, but the proximal ones are much larger than the abactinal plates. Inferomarginals of about the same number as the superomarginals and distally of about the same size and alternating with them ; proximally they are directly beneath them and are considerably smaller. All the marginal plates are covered by granules like those of the abactinal surface; there are papulæ scattered among them. Terminal plate rather large, wider than long, covered by granules. Madreporite small ( $2 \mathrm{~mm}$. across), rounded triangular, half way between centre of disk and margin.

Actinolateral plates in three series; that adjoining the adambulacrals extends to the fourth inferomarginal from tip of arm ; the next extends to the ninth; the third extends to the eleventh or thereabouts, but is distally irregular and

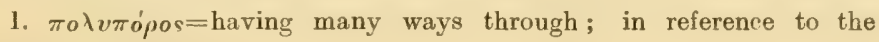
numerous papular pores. 
broken up; all the plates resemble those of the abactinal surface. Papulæ occur everywhere except between the adambulacrals, and on distal half of ray, between the adambulacral series and the adjoining actinolateral series. The granulation on the actinolateral plates near the mouth is coarser, more angular and more widely spaced than elsewhere. Adambulacral plates more than 70, wider than long; furrow margin with 3 (distally 2) stout, prismatic, blunt spines, rather more than a millimeter long; back of this series is a second of 2 or rarely 3 , short, stout, angular spinelets or granules; external to them are 5-8 smaller, angular granules similar to those on the actinolateral plates; except near the mouth, these are usually in two series with 1-3 granules in the inner and 4 or 5 in the outer. Oral plates not conspicuous or peculiar, the marginal and surface spines being essentially like those on the adambulacral plates, though longer, more pointed and more sharply prismatic. No pedicellariæ anywhere, unless pairs, trios and quartettes of low, angular spinelets, more or less appressed to each other, on some of the plates near the mouth, are to be so interpreted. Colour (dry), dirty brownish-white. Three specimens.

The form and size of this Fromia, in connection with its comparatively uniform granulation and its adambulacral armature, easily distinguish it from the other members of the genus. I do not feel certain that the Western Australian specimen is conspecific with those from Tasmania; it has $\mathrm{R}=65$ $\mathrm{mm}$.; $\mathrm{r}=16 \mathrm{~mm}$.; $\mathrm{br}=16 \mathrm{~mm}$.; br at middle of ray $11 \mathrm{~mm}$., and at tip $3 \mathrm{~mm}$.; hence $\mathrm{R}$ is only $4 \mathrm{r}$, and only $4 \mathrm{br}$; moreover, the arms are little flattened and taper uniformly to the slender tip, while there are, as a rule, 3 spines in the second adambulacral series. These differences are so slight, it is sufficient to mention them here and await more abundant material. I am further constrained to do this because there is a Fromia in the Museum of Comparative Zoölogy collection, from Westernport, Victoria, the gift of Mr. J. Gabriel, which is certainly very near to the present species. In it $R=65$ $\mathrm{mm}$, and $\mathrm{r}$ and br are $16 \mathrm{~mm}$., but br at middle of ray is 13 $\mathrm{mm}$., and at tip is nearly $4 \mathrm{~mm}$.; hence the individual is much stouter in appearance than either the Western Australian or Tasmanian specimens; the granulation and adambulacral armature also are noticeably coarser and the papulæ, especially on the actinal surface, seem larger; the terminal plate and adjoining marginal and abactinal plates are perfectly smooth, but it is possible that the granulation has been accidentally rubbed off. A good series of Fromias from the western and southern coasts of Australia, and from Tasmania, 
will be necessary before we can be sure that we are dealing with only a single species.

Locs.-East of Maria Island, Tasmania, 78 fathoms.

Between Geraldton and Cape Naturaliste, Western Australia.

Genus Ophidiaster, L. Agassiz.

OpHidiaster CONFERTUS, ${ }^{1} s p$. nov.

(Plate xv., fig. 1-2.)

$\mathrm{R}=81 \mathrm{~mm} . ; \mathrm{r}=9 \mathrm{~mm} . ; \mathrm{R}=9 \mathrm{r} . \quad \mathrm{Br}=10 \mathrm{~mm}$. $\mathrm{R}=8 \mathrm{br}$. $\mathrm{Br}$ at middle of ray $=10 \mathrm{~mm}$. ; at tip $=6 \mathrm{~mm}$. Disk small ; rays 5, long and cylindrical. Abactinal plates in 3 regular series, about equal in size to marginals. Papular areas in 8 regular series, one on each side of ray, on actinal surface; each area contains 15-20 papulæ. All abactinal and marginal plates more or less conspicuously tumid. Entire animal clothed in a densely granular skin; on papular areas, there are 30-40 granules, or even more, to each square millimeter, but on convexities of abactinal plates, there may be only 10-15, though there are often more. Madreporite single, 2-3 $\mathrm{mm}$. in diameter. Terminal plate scarcely more than a millimeter in diameter, bare. Adambulacral plates short and numerous; on the furrow-margin are 2 blunt, rounded, but flattened spines, about $1 \mathrm{~mm}$. long; the aboral is a trifle the smaller as a rule; the tips of these adambulacral spines are separated from each other by granules such as cover the surface of plates; near the mouth each plate carries an oval, blunt, flattened spine about a millimeter long and rather more than its own length from the furrow-series; distally, these subambulacral spines often occur only on every other plate and the transition from being on every plate to being on every other plate may be abrupt; in such cases the spines near the mouth seem crowded. Oral plates not peculiar, small and completely buried in granules. Pedicellariæ more or less abundant everywhere, but particularly near the mouth and on the papular areas; they are of the well-known type occurring in $O$. germani, $O$. lorioli, etc.; the whole organ is about $.75 \mathrm{~mm}$. long by $.25 \mathrm{~mm}$. wide and each jaw has $3-5$ teeth. Colour (dry), yellow-brown.

1. Confertus $=$ crowded ; in reference to the tendency of the subambuacral spines to be very near together proximally. 
Although not taken by the "Endeavour," this specimen was included in the collection, that a description and figures. might be published. I have also had for comparison, and have used in drawing up the above description, two specimens. also from Lord Howe Island, in the Museum of Comparative Zoölogy collection, received from the Australian Iuseum several years ago. As these bore the manuscript name $O$. confertus, it has seemed well to retain it. The species is near $O$. germani, but has only a single madreporite and the arms are much longer. In my report on the "Thetis" Echinodermata ${ }^{1}$ I, with some hesitation, referred an Ophidiaster from Lord Howe Island to Perrier's species, but in view of these additional specimens, I am now inclined to think these is little doubt that $O$. germani is quite distinet. The character, to the presence of which my hesitation was due, is not, however, a constant one, no two of the specimens being alike in the arrangement of the subambulacral spines, although they are, in all cases, numerous and regularly arranged near the mouth.

Loc.-Lord Howe Island, South Pacific Ocean.

Genus Pseudophidiaster, ${ }^{2}$ gen. nov.

Linckiidre with three conspicuous series of abactinal plates and eight series of papular areas, at base of arms, the actinal series tending to disappear distally, near the tip of the pointed arm. Body-wall thick and leathery with little or no rigidity. Adambulacral armature in a single series. Actinolateral plates in several series at base of arms; no papular areas between them. Pedicellariæ present. Madreporite very large. Ampullæ single, large, with numerous calcareous plates in their walls. No superambulacral plates.

Type-species.--Pseudophidiaster rhysus, sp. nov.

'This remarkable genus does not differ structurally from Ophidiaster in any very fundamental points, but in general appearance the difference is very great. Owing to the lack of rigid abactinal skeleton, dry specimens are very much wrinkled and the longitudinal series of plates are made unnaturally conspicuous ; in alcoholic specimens, longitudinal furrows are not conspicuous, but numerous transverse grooves

1. H. L. Clark-Mem. Austr. Mus., iv., 11, 1909, p. 529.

2. $\psi \epsilon v \delta \dot{\eta} s=$ false + ophidiaster; in reference to its resemblance to that genus not being apparent. 
are evident, especially on the sides of the arms. The superficial appearance of alcoholic specimens of Pseudophidiaster is more like that of Phataria than like that of Ophidiaster, but the latter genus seems to be structurally more nearly allied.

Pseddophidiaster RHysus, ${ }^{1} s p$. nov.

(Plate xvi., fig. 1-2.)

$\mathrm{R}=150 \mathrm{~mm}$. ; $\mathrm{r}=25 \mathrm{~mm}$. ; $\mathrm{R}=6 \mathrm{r}$. $B r=27 \mathrm{~mm}$. ; $\mathrm{R}=$ not quite $6 \mathrm{br}$. $\mathrm{Br}$ at middle of ray, about $15 \mathrm{~mm}$.; at tip, 3-4 $\mathrm{mm}$. Disk large, considerably elevated, the median radial series of plates extending outward from it in equally elevated ridges ; rays therefore more or less distinctly trigonal at base, but tapering quite uniformly to a cylindrical, bluntly pointed tip. Whole animal clothed in a thick skin, bearing a dense coat of crowded granules, and concealing almost completely the skeletal plates; on papular areas, there are 60 or more granules per square millimeter, but on convexities and elevations of disk and base of rays, the granulation is much coarser, sometimes only 4-10 per square millimeter. Median radial series of abactinal plates very conspicuous proximally, but becoming less and less distinct distally; on each side is a much smaller series which, beyond the middle of the arm, becomes irregular and difficult to distinguish; then comes the series of superomarginals which are quite well marked except near tip of ray ; inferomarginals as large or larger, and generally easily followed to very tip of ray, since they form the ventrolateral margin of the arm. Papular areas rather small, each with 20-25 papulæ, forming eight regular series, one on each side of arm being actinal in position, below the inferomarginal plates; distally the series are less regular and the actinal do not reach the tip of the arm. Madreporite very large and conspicuous, $10 \mathrm{~mm}$. long by $8 \mathrm{~mm}$. wide. Terminal plate very small and inconspicuous.

Actinolateral plates in three regular series proximally, with a few plates indicative of a fourth series; the third series disappears about one-third of the distance from mouth to arm tip; the second extends beyond the middle of the arm; the series adjoining the adambulacrals apparently extends nearly to the arm tip. Adambulacral armature of 2 flattened, smooth spines nearly $2 \mathrm{~mm}$. long, with blunt, rounded tips, placed close together, the aboral the slightly smaller of

1. $\rho v \sigma o s=$ wrinkled, shrivelled; in reference to the appearance of dry specimens. 
the two; the adambulacral plates being short and overlapping, the spines are crowded close together in a very regular and unbroken marginal series; the actinal surface of the plates is covered by the same coarse granulation, as the actinolaterals bear; at the very tip of the arm, there occur scattered subambulacral spines, like those of Ophidiaster, while close to the mouth, 3 or 4 plates in each series, carry short heavy spines of the same nature, 1-2 $\mathrm{mm}$. long, and 1-1.5 mm. thick at tip ; occasionally there are two such spines on a plate. Oral spines similar to the adambulacrals but somewhat heavier and more prismatic. Pedicellariæ present in very diverse numbers, of the usual Ophidiastrine type, each about $.75 \mathrm{~mm}$. long, the valves nearly or quite $.50 \mathrm{~mm}$. wide and with smooth valves, which are often low and wide; in one specimen they are fairly abundant on the abactinal surface, but in the others only a very few occur, careful search revealing one here and there on the papular areas; I have found none on the actinal surface. Colour (in alcohol), purplish-brown, each arm with three broad, indistinct cross-bands of a lighter shade; lower surface pale grayish; dried, the specimens become pale, dingy fawn-colour.

This remarkable linckiid is not a handsome Starfish but this is, in part certainly, the effect of preservation. The leathery nature of the body-wall, the form of the rays, the huge madreporite, the absence of superambulacral plates, the presence of pedicellarix and the calcareous plates of the ampullæe combine to make it a very unusual member of the family. The tendency to develop subambulacral spines on the oldest (near mouth) and youngest (near arm-tip) adambulacral plates like those of Ophidiaster are suggestive of a phylogenetic connection with that genus and perhaps we shall not be far from the truth if we called Pseudophidiaster a deep-water ophidiasterid. The smallest specimen before me has $\mathrm{R}=58 \mathrm{~mm}$.; $\mathrm{r}=8 \mathrm{~mm}$.; $\mathrm{R}=7 \mathrm{r}$; in other particulars, it is not noteworthy.

Locs.-Great Australian Bight, 80-120 fathoms.

Thirty-six miles N. $58^{\circ}$ E. of Cape Wickham, King Island, Bass Strait.

South of Gabo Island, Victoria, 200 fathoms.

Oyster Bay, Tasmania, 60 fathoms. 
Family ASTERINDA.

Genus Asterina, Nardo.

ASterina ATYPHOIdA, ${ }^{1} s p$. nov.

(Plate xvii., fig. 1-2.)

Remarkably similar to $A$. modesta, Verrill, from Panama. On the upper surface the only difference is in the coarser granulation of the plates in the Australian specimens. Actinally the difference is somewhat more marked; the adambulacral plates almost never have more than one subambulacral spine, while in $A$. modesta two such spines are often, if not usually, present; the actinal intermediate plates near the margin have only a single spine while in $A$. modesta there are two and occasionally three. The largest specimen of $A$. atyphoida is $19 \mathrm{~mm}$. across; $\mathrm{R}=10 \mathrm{~mm}$., and $\mathrm{r}=8.5 \mathrm{~mm}$. Colour (dry), light brown or whitish. Four specimens.

The resemblance between these South Australian Asterinas and specimens of $A$. modesta from Panama is very extraordinary, whether one regards it as indication of genetic relationship or as a case of parallelism. In either case, the degree of difference is very slight in view of the fact that several other species of Asterina occur in the vast intervening distance between the homes of the two species. It is obviously impossible, without far more data and specimens than are now available, to determine what the relationship between them really is.

Locs.-Fifteen miles north-west of Cape Jervis, South Australia, 17 fathoms. This specimen has been selected as the holotype.

Off Cape Marsden, Kangaroo Island, South Australia, 17 fathoms.

\section{Asterina Leptalacantha, ${ }^{2} s p$. nov.}

(Plate xviii., fig. 3-4.)

$\mathrm{R}=18 \mathrm{~mm}$. ; $\mathrm{r}=8 \mathrm{~mm}$. ; $\mathrm{R}=2.25 \mathrm{r} . \quad \mathrm{Br}=9 \mathrm{~mm}$. ; $\mathrm{R}=$ $2 \mathrm{br}$. Br at middle of ray $=7 \mathrm{~mm}$. ; at tip, $3 \mathrm{~mm}$. Disk and rays moderately arched, but general appearance flattened; margin formed by the conspicuous inferomarginals. Abactinal plates as usual in Asterina, more or less markedly

1. ürvфos= the Latin modestus $+\hat{\epsilon}\llcorner\delta o s=$ form; in reference to the resemblance to $A$. modesta, Verrill.

2. $\lambda \epsilon \pi \tau a \lambda \epsilon^{\prime} \sigma s=$ fine, slender $+a^{\prime} \kappa a \nu \theta a=$ thorn, spine; in reference to the very fine spines on the inferomarginal plates. 
imbricating and with a proximal notch or concavity for the subtending pajula ; there are no small supplementary plates ; across the base of the ray one may count 10-12 series of plates but only 8 or 6 distally above the superomarginals; at base of ray there are 5-7 series of papulæ but only three (or two) extend beyond the middle of ray. Except for a few minute spinelets around the anus and around the madreporite, all the abactinal plates, but 10 or so in each interradial angle, are perfectly bare and smooth ; the interradial plates referred to each carry $6-10$ exceedingly slender spines, $.75 \mathrm{~mm}$. long. Superomarginal plates small and perfectly bare. Inferomarginals about 24 on each side of ray, very conspicuous, each one bearing a tuft of 12-15 (or more) exceedingly slender spines 1-1.5 mm. long. Actinolateral plates in two complete series, while a third runs as far as the twentieth (from interradius) inferomarginal; there are 5 or 6 plates in a fourth series, and a few additional plates in the interbrachial are; except the three most adoral plates of the first series, which are perfectly bare, each of these plates carries a single, sharp, relatively stout spine nearly a millimeter long; in each interradial area except one, back of the oral plates, is a small bit of naked, uncalcified skin. Adambulacrals about 26, all but the two most adoral, corresponding to an inferomarginal with the intervening actinolaterals; armature consists of a furrow series of 5 (4-6) spines, the middle one longest, adoral and aboral ones shortest, and a single prominent subambulacral spine on the surface of the plate. Oral plates rather large, with only 5 marginal spines, the terminal much the largest, and a single big spine on the surface. Madreporite small, triangular, nearer centre of disk than margin. Colour (dry), pale yellow-brown.

This very interesting Asterina, while not collected by the "Endeavour," is included in the collection sent me, and certainly deserves description. It belongs in the section of the genus to which Verrill has recently given the name Patiriella, the type of which is $A$. regularis from New Zealand. But there is little superficial resemblance between A. leptalacantha and A. regularis and if Asterina is to be broken up, one would hardly expect them to fall into the same section. The new Australian species cannot be mistaken for any hitherto described, the relatively long arms, the bare abactinal plates, the remarkable inferomarginals and the spinulation of the actinal surface forming a very distinctive group of characters.

Loc.-Masthead Island, Queensland, collected by Mr. A. R. NicCulloch, December, 1913. 
SEA LILIES, STARFISHES, ETC.-CLARK.

Genus Anseropoda, Nardo.

ANSEROPODA ROSACEA (Lamarck).

(Fig. 5-6.)

Asterias rosaceus, Lamarck, Anim. sans Vert., ii., 1816 , p. 558, par. 3 .

Anseropoda rosacea, Fisher, Bull. U.S. Fish Comm., 1906, p. 1089.

Evidently this is a more widely distributed species than was supposed, since it is now known from Japan, the Indian

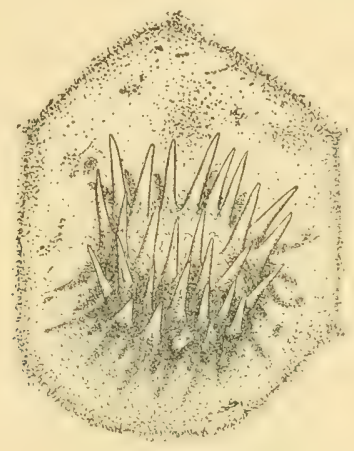

Fig. 5.x40.

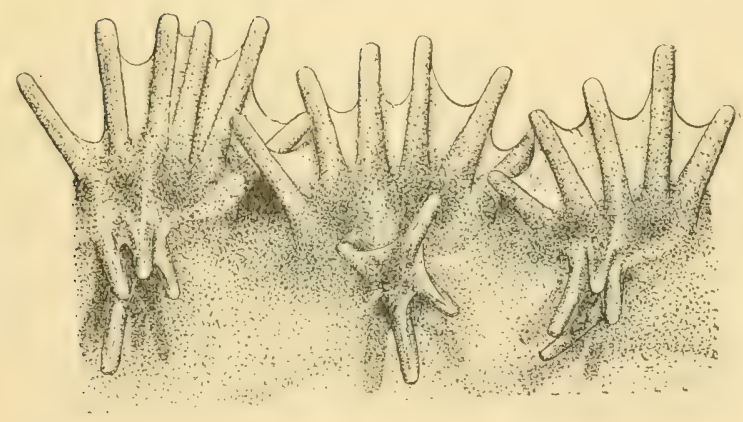

Fig. 6.x15.

Ocean, the western coast of Australia, and the eastern coast of Queensland. No doubt it will soon be reported from the East Indies. The specimens in the "Endeavour" collection have $R=85-115 \mathrm{~mm}$. ; two have 15 and two have 16 rays. They 
are pale, dirty grayish, or brown, and show no trace of any of the original colours. Four specimens.

Locs.-Off Fraser Island, Queensland, 32 fathoms.

Twenty-five miles south-east of Double Island Point, Queensland, 33 fathoms.

\section{Family ECHINASTERIDÆ.}

Genus Henricta, Gray.

Henricia hyadesi (Perrier).

Cribrella hyadesi, Perrier, Miss. Sci. Cap-Horn, vi., Zoologie, Echinod., 1891, p. K100.

Henricia hyadesi, Fisher, Bull. U.S. Nat. Mus., Ixxvi., 1911, p. 293.

Although these specimens show considerable diversity in proportions and in spinulation, in view of the well-known inconstancy of characters in the genus, I do not feel justified in recognising more than one species, and that one $\mathbf{I}$, for the present, identify with Perrier's species from southern South America. I cannot go as far as Ludwig and consider all the Antaretic and sub-Antaretic Henricias as a single species, for I doubt if Studer's $H$. pagenstecheri is identical with Perrier's $H$. hyadesi, and I am quite prepared to learn that the Australian and South American Henricias are distinct. But until more material is available, it is futile to discuss the matter. It is worthy of note that all the Australian specimens are from water relatively deep for the genus. The largest specimen has $R=80 \mathrm{~mm}$. ; in another $R=75 \mathrm{~mm}$.; $b r=18 \mathrm{~mm}$. ; in a third, $R=67 \mathrm{~mm}$. ; $b r=9 \mathrm{~mm}$. Usually the arms taper to a slender tip, but in one specimen they are rather uniformly stout. One specimen from the Great Australian Bight has 6 arms but does not seem to differ otherwise from the rest. All the specimens have lost their original colours, and are now some shade of yellowish-brown. Eleven specimens.

Locs._East of Maria Island, Tasmania, 78 fathoms.

Off Babel Island, Bass Strait, 50-60 fathoms.

South of Gabo Island, Victoria, 200 fathoms.

Great Australian Bight, 80-150 fathoms. 


\section{Genus ECHINASTER, Müller and Troschel.}

ECHiNASTER ACANTHODES, ${ }^{1} s p$. nov.

(Plate xix., fig. 1-2; Fig. 7.)

$\mathrm{R}=70 \mathrm{~mm}$. ; $\mathrm{r}=12 \mathrm{~mm}$. ; $\mathrm{R}=6 \mathrm{r} . \mathrm{Br}=14 \mathrm{~mm}$. $\mathrm{R}=5$ br. $\mathrm{Br}$ at middle of ray $=9 \mathrm{~mm}$; at tip, $3.5 \mathrm{~mm}$. Disk moderate, slightly arched; arms terete, tapering very uniformly to the narrow but blunt tip. Abactinal skeleton coarse and rather heavy; each plate bears a large sharp spine, .5-1 mm. high. Papulæ confined to abactinal surface; the areas in six irregular longitudinal series, each area with few (2-6) papulæ. Adambulacral armature consisting of 3 spines in a vertical series, the smallest high up in ambulacral furrow, the second, little larger, just below, and the third, much larger, on the furrow-margin; except on the 12-16 plates nearest the mouth, there occurs on the actinal surface of every other plate, a conspicuous subambulacral spine, equal to, or larger than, that on the furrow-margin; back of this

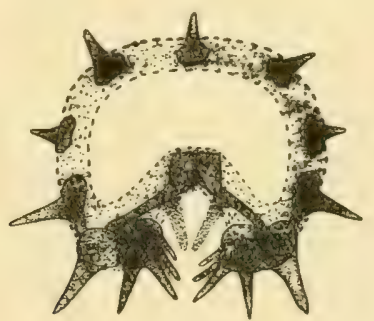

Fig. 7.x3.

spine, on the actinolateral or more likely the inferomarginal plate, is another still larger spine, about $2 \mathrm{~mm}$. high. Oral plates with no surface spines and marginal spines united by membrane, which reaches more or less nearly to their tips, and extends outwards along the rays uniting more or less evidently the furrow-margin spines of the first few adambulacral plates. Beyond the disk, each spine is more or less clothed in membrane. Madreporite very small, about halfway between disk-centre and margin. Colour (dry), light brown. Three specimens.

The general appearance of this species is more like that of the West Indian Echinasters than like that of its East Indian congeners. The conspicuous spines and the total lack of

1. $\dot{\kappa} \kappa \boldsymbol{\nu} \theta \dot{\omega} \delta \eta \varsigma=$ full of thorns; in reference to the spiny surface. 
actinal papulæ make it an easy species to recognise. The smallest of the three specimens has $R=30 \mathrm{~mm}$., and the more or less isolated papulæ are in about 4 irregular series. There is only 1 prominent actinal spine for each 3 adambulacral plates, until near tip of arm. The membrane between the adambulacral plates has distinct non-calcified actinal areas about $.35 \mathrm{~mm}$. wide by $.25 \mathrm{~mm}$. long.

Locs.-Twenty-five miles south-east of Double Island Point, Queensland, 33 fathoms.

Thirteen miles north-east of North Reef, Capricorn Group, off Point Curtis, Queensland, 70-74 fathoms.

\section{EChinaster eridanella, Müller and Troschel.}

(Plate xx., fig. 1-2 ; Plate xxi., fig. 1-2.)

Echinaster eridanella, Müller and Troschel, Sys. der Ast., 1842 , p. 24.

There is a bare possibility that the little specimen with 5 arms from twenty-five miles south-east of Double Island Point, Queensland, $\mathrm{R}=25 \mathrm{~mm}$., is not this species, but except for the number of arms, I see no occasion for questioning it. The species is abundant on the reefs of northern Queensland, and it is quite possible that it reaches southward to twentyfive miles south-east of Double Island Point. Of the specimens figured, those from Bowen, Queensland, and from Murray Island, Torres Strait, are typical of the species; the 4-rayed specimen from Mauritius is exceptional and is, moreover, poorly preserved. Three specimens.

Locs.-Bowen, Queensland. A specimen with seven rays.

Twenty-five miles south-east of Double Island Point, Queensland, 33 fathoms. A small specimen with five rays.

\section{ECHINASTER GLOMERATUS, ${ }^{1} s p$. nov.}

(Plates xxii.-xxiii. ; Fig. 8.)

$\mathrm{R}=135 \mathrm{~mm}$.; $\mathrm{r}=25 \mathrm{~mm}$.; $\mathrm{R}=5.5 \mathrm{r} . \mathrm{Br}=25 \mathrm{~mm}$. ; $\mathrm{R}=$ $5.5 \mathrm{br}$. Br at middle of ray $=18 \mathrm{~mm}$. ; at tip, $5 \mathrm{~mm}$. Disk large, moderately elevated as are the bases of the broad, steadily tapering arms. Madreporite very small; in holotype, only about $7 \mathrm{~mm}$. from centre of disk but nearer the margin in other specimens. Abactinal skeleton very coarse

1. Glomeratus=grouped; in reference to the arrangement of the :abactinal spines. 
and heavy, forming a wide-meshed network with rather large papular areas; wherever two or more plates meet is an elevation bearing a cluster of 2-12 stout, sharp spines, .5-1 $\mathrm{mm}$. high; the papular areas contain 12-15 or more papulæ; neither spine-clusters nor papulæ show any serial arrangement. Actinal surface somewhat flattened; adambulacral plates very numerous; their armature shows some diversity ; well up in the furrow is a sharp, slightly eurved spine, below which is a second larger and somewhat blunter and straighter one; below the latter is, generally, a similar but slightly larger spine, about $3 \mathrm{~mm}$. long, which stands on the furrow

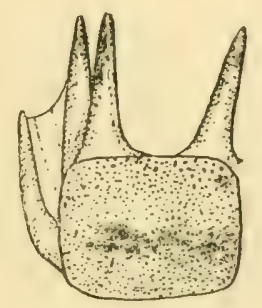

Fig. 8.x5.

margin and just outside of it, on the actinal surface of the plate is a similar but much shorter spine ; diversity comes from the fact that there may be two or even three spines, instead of one on the furrow margin and they may stand side by side or in an oblique row, extending aborally from the margin; the marginal and furrow-spines are more or less encased in membrane. The actinolateral plates, outside the adambulacrals, seem to correspond to them in number, and each one bears a series (transverse to long axis of ray) of 2-3 sharp spines. Papulæ are abundant on the actinal surface, but do not occur between the actinolaterals and adambulacrals, nor on the actinal interradial areas. Oral plates not peculiar, but the lateral spines are not concealed by the thin membrane which unites them. Colour (in alcohol), bright yellow-brown; (dry) similar, but duller.

Strictly speaking this species belongs in Henricia rather than in Echinaster since the spinelets are in groups and not isolated, but the general appearance is so unlike Henricia that it seems absurd to put it in that genus. It is quite unlike any previously described Echinasterid and will be easily recognised at once. The smallest of the six specimens at hand has $R=75 \mathrm{~mm}$. ; it is not, however, notably different 
from the larger specimens, save that the actinal skin is thicker and unites and conceals the spines along the furrow more fully.

Loc.-Off Cape Marsden, Kangaroo Island, South Australia, 17 fathoms.

\section{ECHINASTER SUPERBUS, ${ }^{1} s p$. nov.}

(Plates xxi $\cdot-\mathbf{x x v}$; Fig. 9-10.)

$\mathrm{R}=110 \mathrm{~mm}$.; $\mathrm{r}=15 \mathrm{~mm}$. $\mathrm{R}=7 \mathrm{r} . \quad \mathrm{Br}=20 \mathrm{~mm}$.; $\mathrm{R}=$ $5.5 \mathrm{br}$. Br at middle of ray $=14 \mathrm{~mm}$.; at tip, $4 \mathrm{~mm}$. Disk small, not elevated; rays nearly terete, tapering uniformly to tip, somewhat flattened actinally. Abactinal skeleton pretty well concealed in the thick skin, but forming a rather fine mesh-work, with relatively small papular areas, which show no serial arrangement. Papulæ large and numerous. Abactinal spines numerous, isolated, diverse in form, 1-2 mm. high, .5-1.75 mm. thick; few have a simple, pointed or blunt, tip; usually it is clavate to a greater or less degree, chiselshaped with one or more notches, or with 5-6 low, rounded summits. Madreporite moderately large, very distinct and quite near centre of disk. Adambulacral plates numerous,
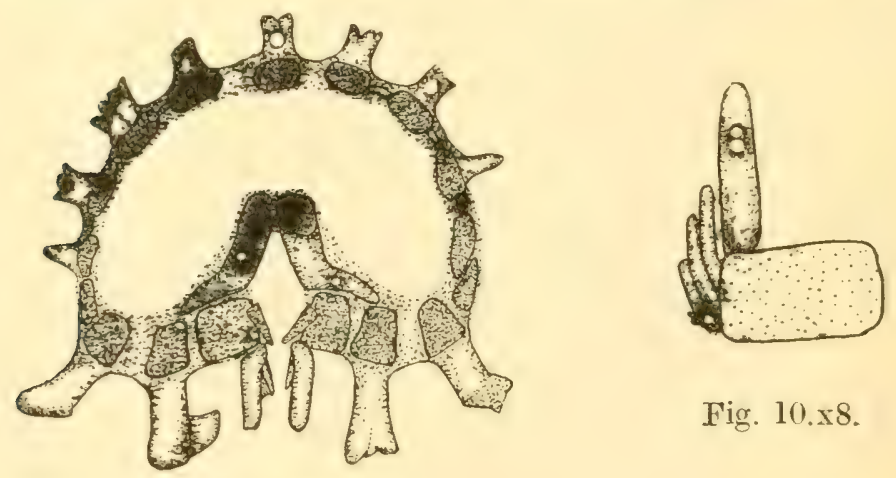

Fig. 10.x8.

Fig. 9.x4.

about twice as wide as long, very well defined, separated from each other by distinct membranous spaces half as long as the plates; each plate carries, high up in the furrow, a small, curved pointed spine, immediately below which is a

1. Superbus=very fine; in reference to its notable form and size. 
longer, straighter, stouter one; close to this, but on the furrow-margin is a large flattened spine, $2-2.5 \mathrm{~mm}$. long and about as wide as the length of the plate; its outer side is more or less deeply furrowed (at least near tip) and its summit is a chisel-shaped or clavate edge ; approximately every other spine is narrower, smoother and more nearly pointed, but there is considerable diversity. On the actinal surface of a very few plates, on the basal part of the ray, occurs a single, low pointed tubercle or spine. Outside the series of adambulacral plates oceurs a very conspicuous series of spines, the largest on the Starfish; there are 2 of these to every 5 adambulacral plates; they are $2 \mathrm{~mm}$. high or more, and their conspicuous chisel-shaped or clavate tips are frequently more than $2 \mathrm{~mm}$. wide; outside this series, and virtually forming the boundary of the actinal surface, is a series of similar but smaller and more numerous spines, large ones often alternating with small ones as in the adambulacral series. Papulæ occur between these two actinal series of spines. Oral plates and spines not peculiar or notable. Colour (dry), deep purplishbrown, tips of the spines lighter but apparently only by abrasion.

This is another remarkable Echinaster, unlike any previously known, and making the fourth notable species known only from Australia, besides the long-known East Indian species, $E$. eridanella and African $E$. vestitus. It is interesting that with one exception, each of these six species occurs on a different part of the coast; the present species $E$. superbus comes from the far north-west of the continent; two hundred miles further south, at Port Hedland, $E$. vestitus and the very different $E$. arcystatus have been taken; over two thousand miles of coast separate these three species from $E$. glomeratus of South Australia; another gap of some one thousand five hundred miles separates that sharply distinct species from $E$. acanthodes of southern Queensland; and just overlapping the latter's area is the southern limit of $E$. eridanella, the common species of northern Queensland. Of course further collections and studies may show that these geographical lines of division do not really exist in nature but their apparent occurrence seems worth noting. Unlike the various forms of Echinaster in the West Indian region to which different names have been given, these Australian species are very obviously different from each other and it is difficult to conceive of their intergrading.

Loc-Broome, Western Australia. 
Genus Plectaster, Sladen.

Plectaster decanus (Müller and Troschel).

(Plate xxvi., fig. 1-2.)

Echinaster decanus, Müller and Troschel, Arch. f. Naturg., ix.i., 1843, p. 114.

Plectaster decanus, Sladen, Chall. Rep., Zool., xxx., 1889, p. 535 .

This remarkable species never having been figured, it seems desirable to figure it here, and the Port Jackson specimen is shown on Pl. xxvi., fig. 1-2. In it, $R=115 \mathrm{~mm}$., and $r=27 \mathrm{~mm}$.; $\mathrm{R}=4 \mathrm{r}$. The specimens from Shoalhaven Bight, New South Wales, are smaller and not so well preserved, but they appear to have been placed in formalin and then dried, and hence are more nearly the natural colour. In them the papula areas are bright reckish-purple, while the skeleton and spinelets are light yellowish in sharp contrast; on the actinal surface, there is a considerable suffusion of reddish-purple, especially interradially, near the mouth. The Port Jackson specimen is yellowish-brown, the papular areas darker than the skeleton. Three specimens.

Locs.-Shoalhaven Bight, New South Wales, 15-45 fathoms.

Off George Head, Port Jackson, New South Wales.

\section{Family SOLASTERDA.}

Genus Crossaster, Müller and Troschel.

Crossaster ardtispinds, ${ }^{1} s p$. nov.

(Plate sviii., fig. 5-6.)

Rays 11. $R=40 \mathrm{~mm}$. ; $\mathrm{r}=20 \mathrm{~mm}$.; $\mathrm{R}=2 \mathrm{r} . \mathrm{Br}=10$ $\mathrm{mm}$. ; $\mathrm{R}=4 \mathrm{Br}$. Abactinal skeleton an open mesh-work of narrow, rather delicate ossicles, leaving large papular areas, in which, however, the papulæ are few, large, isolated. Pseudopaxillæe rather crowded on disk, but more widely spaced on arms; each bears a tuft of 8-15 long, slender, acicular spines, exceeding the stalk in length. Superomarginals insignificant. Inferomarginals few, widely spaced, conspicuous, about 16 on each side of an arm; they are greatly compressed at summit into a narrow vertical ridge, carry 25 (more or fewer) sharp, spinelets, most of which are shorter than those on the abactinal pseudopaxillæ. Actinal

1. Multispinus = with many spines ; in reference to the armature of the adambulacral and oral plates. 
intermediate plates, few and scattered, with 6-12 spinelets; actinolateral plates very few, small and scattered, with very few spinelets. Adambulacral plates as wide as long, or wider; the furrow margin bears 8 or 7 (proximally), 6 or 5 (distally), slender, not sharp, membrane-united spines, the middle ones longest, $1.5-2 \mathrm{~mm}$. long ; actinal surface of plate with a transverse, slightly eurved series of 7-9 similar spines, 2-3 mm. long. Oral plates with a marginal series of 14 similar spines, the proximal longest and largest, $3-3.5 \mathrm{~mm}$. long; actinal surface of each plate with a longitudinal series of 8-10 similar spines, near inner margin. Madreporite small and inconspicuous, half way between centre of disk and margin. Colour (dry), dull brown; other specimens are light yellowish-brown.

Although all four specimens have 11 rays each, the three from Tasmania are obviously different from the holotype, in their lighter colour, more conspicuous skeleton, more slender rays, and thinner and less noticeable membrane covering and uniting the spines, both abactinally and actinally. In view of the well-known diversity in all such particulars shown by the common, northern species of Crossaster (C. papposus), I think there is little reason to consider these differences of any special significance, especially since the Tasmanian specimens are poorly preserved. The large number, and the slenderness of the adambulacral and oral spines readily distinguish the present species from any of those previously known.

Locs.-Between Gabo Island, Victoria, and Disaster Bay, New South Wales, 50-100 fathoms. This specimen has been selected as the holotype.

South-east of Bruni Island, Tasmania, 150-230 fathoms.

Genus Pteraster, Müller and Troschel.

Pteraster tetracanthus ${ }^{1} s p$. nov.

(Plate xviii., fig. 1-2.)

$\mathrm{R}=30 \mathrm{~mm}$. ; $\mathrm{r}=24 \mathrm{~mm}$. ; $\mathrm{R}=1.25 \mathrm{r}$. General form almost perfectly pentagonal, moderately thick. Abactinal surface in such poor condition it is not possible to determine exactly the number of paxillar spines; paxillæ somewhat numerous and paxillar spines long, apparently about 6. Spiracles

1. тєтрака $\theta_{o s}=$ having four spines; in reference to the armiature of the adambulacral plates. 
small and seemingly widely scattered. Actinolateral spines only $5 \mathrm{~mm}$. long, hence actinolateral membranes cover a relatively small part of actinal surface, and actinal intermediate areas are large and densely covered with groups of slender, membrane-united spinelets. Adambulacral spines 4, the innermost very small, the outermost about $4 \mathrm{~mm}$. long, united by a thin membrane, which retreats little (say $25 \%$ ) between the spines, and which connects with the actinolateral spine. Actinolateral membrane reaches practically to tips of spines, with little retreat between. Oral plates with prominent central keel and very stout suboral spines (one on each plate), $4 \mathrm{~mm}$. long, sharply triangular near tip, but truncate and more or less succulate; oral spines 4 , of which the first (proximal) is much larger than the next, about $3 \mathrm{~mm}$. long, truncate and flat ; no membrane connects these spines. Colour (dry), dull grayish-brown.

This specimen is the first representative of the genus to be taken anywhere near Australia. Judging by the keys to Pteraster which have been published one would expect either $P$. dano, Verrill, or $P$. stellifer, Sladen, to be near allies, but in reality the present species is quite unlike either of these. The large actinal interradial areas, the narrow actinolateral membrane and the characters of the oral armature combine to give $P$. tetracanthus a very distinctive facies.

Loc.- South-east of Cape Everard to south of Gabo Island, Victoria, $90-150$ fathoms.

\section{Family ZOROASTERID $A$.}

\section{Genus Zoroaster, Wyville-Thomson.}

\section{ZOROASTER MACRACANTHA, ${ }^{1} s p$. nov.}

(Plate xxviii., fig. 1-2.)

Very similar to $Z$. spinulosus, Fisher, from the Hawaiian Islands, but differing in a few details. The plates of the medioradial series are the largest on the arm and each succeeding series is made up of smaller plates; the superomarginals are thus larger than the inferomarginals. Two series of actinolateral plates are confined to the actinal surface at the base of the arm. The plates of the medioradial series are provided with large central tubercles (bosses) on which are articulated stout sharp spines $5 \mathrm{~mm}$. or more in length; on the basal part of the arm such a spine occurs on nearly every

1. $\mu \alpha \kappa \rho o s=$ long $+\ddot{\kappa} \kappa \alpha \nu \theta a=a$ thorn, or spine; in reference to the long abactinal spines. 
medioradial plate, but distally only on every other plate ; there is never more than one to a plate; nearly all these spines are missing in the specimens at hand, but the tubercles are conspicuous and enough spines are left to show their size. The superomarginals bear similar but smaller and more slender spines. Pedicellariæ both large and small are present everywhere, very large ones, 1.5-2 $\mathrm{mm}$. long, occurring on the medioradial plates. Adambulacral armature essentially as in $Z$. spinulosus but pedicellariæ appear to be much more abundant. Colour (in alcohol), yellowish-brown. Three specimens.

It is not without some hesitation that I separate this Zoroaster from the Hawaiian species, but until something is known of the fauna of the vast area between southern Australia and the Hawaiian Islands, it seems best not to assume the identity of species in the two regions. Apparently the Australian Zoroaster is conspicuously more spiny than its Hawaiian congener, and since the medioradial plates and spines seem to furnish a tangible character, I have determined to give it a different name. The largest specimen has $\mathrm{R}=$ $160 \mathrm{~mm}$.; $\mathrm{r}=14 \mathrm{~mm}$.; $\mathrm{R}=11.5 \mathrm{r}$. The primary disk-plates have prominent bosses like those on the medioradial plates and apparently, in life, bore similar conspicuous spines.

Loc.-Great Australian Bight, $129^{\circ} 28^{\prime}$ E., 250-450 fathoms.

\section{Family PEDICELLASTERIDA.}

Genus Pedicellaster, Sars.

Pedicellaster Reticulatus ${ }^{1} s p$. nov.

$$
\text { (Plate xxvii., fig. 3-4.) }
$$

Rays 6 , unequal, three larger and three smaller ; the middle one of the smaller trio much smaller than the others, being about $22 \mathrm{~mm}$. long, while they are over $30 \mathrm{~mm}$. $R=37 \mathrm{~mm}$.; $\mathrm{r}=5$ or $6 \mathrm{~mm}$. ; $\mathrm{R}=6$ or $7 \mathrm{r} . \mathrm{Br}=5 \mathrm{~mm}$. ; $\mathrm{R}=7 \mathrm{br}$. $\mathrm{Br}$ at middle of ray, $3.5 \mathrm{~mm}$. ; at tip, $1.5 \mathrm{~mm}$. Disk small ; arms relatively broad for a Pedicellaster. Abactinal skeleton made up of slender rods and plates forming a large-meshed network; on each arm there are about 4 longitudinal series of these meshes, with 20-25 meshes in each series; at many

1. Reticulatus = with meshes like a net; in reference to the widespaced skeleton. 
points, there are only 3 series, a median, and one lateral on each side. Each mesh contains one or more papulæ, but in the dry specimen, it is difficult to determine their presence. Each plate of the skeleton bears a single, slender, pointed spine, 1-1.5 $\mathrm{mm}$. long; also numerous small pedicellarix, which may be either on the plate itself or on the spine or on both ; often the spines, particularly along the actinal margin, have large wreaths or half-wreaths of pedicellariæ. Adambulacral plates, 15 to 5 marginals, at base of arm ; armature of 2 spines, in a transverse series; they are about $1.5 \mathrm{~mm}$. long and subequal or the outer a trifle the longer ; the outer is also a trifle more adoral. There are a very few, scattered, small pedicellariæ just within the margin of the ambulacral furrow, which is notably broad and has the tube-feet in two distinct and wellseparated series. Oral plates not large, but projecting distally so as to slope sharply into the mouth; each one bears 3 smooth spines; one on the actinal surface, which is similar to, about as long as, but stouter than the adambulacral spines; a second is still stouter and blunter and stands at the proximal end of the plate; while the third is much shorter than either of the others, is situated at the proximo-lateral corner of the plate and extends straight out across the ambulacral furrow ; it carries a few small pedicellariæ. Madreporite large $(2 \mathrm{~mm}$. across), conspicuous, near margin of disk. Colour (dry); skeleton and spines, white; membranes and feet, brown.

This species is quite unlike the Atlantic members of the genus but bears considerable resemblance to $P$. improvisus, Ludwig, from the Galapagos Islands. It differs noticeably in the armature of the oral plates, however, as well as in some other details (number of papulæ, length of spines, etc.). The inequality of the arms suggests that schizogony occurs, but it is possible that the condition of the present specimen is accidental.

Loc.-East of Maria Island, Tasmania, 78 fathoms.

\section{Family ASTERIID E.}

Genus Allostichaster, Verrill.

Allostichaster polyplax (Müller and Troschel).

Asteracanthion polyplax, Müller and Troschel, Arch. f. Naturg., x. i., 1844, p. 178.

Allostichaster polyplax, Verrill, Harriman Alaska Exped., Starfishes, 1914, p. 363.

It is a little odd that this well-known Australian Starfish should have been taken only at Oyster Bay, Tasmania; not 
all are labelled thirty fathoms and it is possible they were not all taken at that depth, nor at the one spot. One has only 4 arms, having divided very recently ; a second has 6 arms, with indication of a seventh; a third has 9 arms; the remainder have eight. None are notably large or small. Seven specimens.

Loc.-Oyster Bay, Tasmania, 30 fathoms.

Genus Cosmasterias, Sladen.

Cosmasterias DYSCRITA, ${ }^{1} s p$. nov.

(Plate xxix., fig. 1-2.)

Rays 5. $R=67 \mathrm{~mm}$. ; $r=11 \mathrm{~mm}$. $R=6 \mathrm{r} . \mathrm{Br}=15 \mathrm{~mm}$. $R=4.5$ br. $B r$ at middle of ray $=12 \mathrm{~mm}$. ; at $20 \mathrm{~mm}$. from disk-centre, $17 \mathrm{~mm}$; at tip, $2.5 \mathrm{~mm}$. Disk small, somewhat arched; rays slightly contracted at base, then increasing quickly to maximum breadth, and then tapering steadily to the narrow tip. Abactinal skeleton thick, moderately heavy, with small and distinct papular areas; those on disk contain 3-7 papulæ, while the larger ones along sides of ray have 6-8. Disk plates without definite arrangement, bearing 2-10 low capitate spinelets, about $.5 \mathrm{~mm}$. high and $.25 \mathrm{~mm}$. thick at tip ; there are also a very few big felipedal (as Verrill calls them) pedicellariæ, nearly a millimeter long scattered here and there, besides numerous minute pedicellariæ of the ordinary type ; neither spines nor pedicellariæe are in the least crowded at any point. Madreporite not very large but quite conspicuous, being situated at the centre of a large, elevated plate, half way between disk-centre and margin, surrounded by a circle of 12-15 spinelets. Abactinal plates of rays similar to those of disk but arranged in 13 series at base of arms, a medioradial series with a dorsolateral series on each side, then the superomarginals, the inferomarginals, and 3 series of actinolaterals ; of the latter, the series next the adambulacrals extends less than one-third of the ray, the second reaches to about the middle of ray or a little beyond, and the third goes to within $15-20 \mathrm{~mm}$. of the tip. All the plates above the actinolaterals carry capitate spinelets and pedicellariæ like the disk-plates, usually only 2-3 spinelets on a plate; the actinolaterals each carry one, or often two spines, the largest on the Starfish; near the mouth they are $2 \mathrm{~mm}$. long, blunt, somewhat flattened and nearly a millimeter wide; on the

1. $\delta \dot{v} \sigma \kappa \rho \iota \tau o \varsigma=$ hard to determine ; in reference to the uncertain relationships of the species. 
outer series of actinolaterals these spines are somewhat smaller and intergrade with similar spinelets on the inferomarginals. Papulæ and small pedicellariæ occur between the second and third series of actinolaterals.

Adambulacral plates numerous, about 13 to 5 adjoining actinolaterals at base of arm; armature diplacanthid, the spines 1.5-2 mm. long, the inner ones pointed, the outer blunt and slightly flattened; between the two series occur numerous very large pedicellariæ, those near the mouth being distinctly felipedal; pedicellarix both large and small occur also within the ambulacral furrow. Oral plates, each with 4 spines, an inner proximal at the tip of the jaw, $2 \mathrm{~mm}$. long, moderately stout and pointed; an outer proximal at the corner of the jaw, much smaller and extending outwards across the furrow ; and two actinal spines behind the inner proximal, similar to it, but longer and stouter and forming with it a longitudinal series of 3 ; there are also numerous small pedicellariæ and one or more of the big felipedal ones. Tube-feet in 4 distinet, not greatly crowded series. Colour (dry), brownish-yellow.

This Starfish is undoubtedly a Stichaster in the old broad sense, but Verrill has well shown, what others have suspected, that Stichaster was a heterogeneous and unnatural assemblage. The present species shows some affinity to Asteracanthion luridum, Philippi (=Asterias sulcifera, Perrier) of southern South America, for which Sladen made the subgenus Cosmasterias. Verrill has raised the group to generic rank, including certain species which Sladen considered Stichasters and I think his action is correct and wise. The genus is characteristic of southern South America and that vicinity, so that the discovery of a species which seems to belong to it, in deep water south-east of Australia is of considerable interest. The Australian species is easily recognised by its general facies, short, capitate, scattered spines and adambulacral and oral armature.

Loc.-South of Gabo Island, Victoria, 200 fathoms

Genus Coscinasterias, Verrill.

Coscinasterias calamaria (Gray).

Asterias calamaria, Gray, Ann. Mag. Nat. Hist., vi., 1840, p. 179

Coscinasterias calamaria, Perrier, Exped. Sci. du "Travailleur" et du "Talisman," Echinod., 1894, p. 106.

This individual has 11 arms, of which 3 are very small; for the others, $R=60 \mathrm{~mm}$. There are no large pedicellariæ any- 
where so far as I can discover, in which particular this specimen agrees with individuals from Westernport, Victoria.

Loc.-Sanders Bank, Kangaroo Island, South Australia, 28 fathoms.

\section{Coscinasterias dubia, $H$. L. Clark.}

(Plate xxx., fig. 1-2; Fig. 11.)

Coscinasterias dubia, H. L. Clark, Mem. Austr. Mus., iv., 11, 1909, p. 532.

This is a much better series of specimens than those collected by the "Thetis" on which the species was based. They are as a rule very well preserved and range in size from $\mathrm{R}=22 \mathrm{~mm}$. to $\mathrm{R}=138 \mathrm{~mm}$. The pedicellariæ are much more numerous, particularly along the ambulacral furrow, than in the "Thetis" specimens, and the membrane connecting the marginal spines is not distinguishable; it is probable that its conspicuousness in the "Thetis " specimens was due to their poor preservation. The second series of actinolateral spines is often provided with wreaths of pedicellariæ. As growth changes, one notes that in the smallest specimen while there are 5 fairly well-marked series of plates on the abactinal surface, above the inferomarginals, half or more of the superomarginals carry no spines; there is only one series of actinolateral spines and this is confined to the basal half of the arm ; the inferomarginal spines are relatively long and narrow, not at all widened at the tip; large pedicellariæ are relatively few and are virtually wanting along the ambulacral furrow.

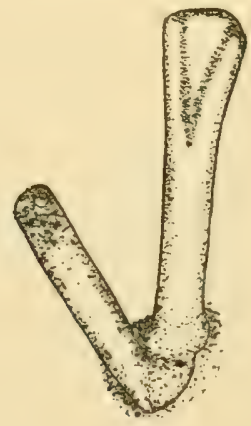

Fig. 11.x15.

In the largest specimen, on the other hand, one notes that while all the superomarginals carry conspicuous spines, there 
are still only 5 series of abactinal spines, but the adradial series is very irregular, so that the broad space between the medioradial series and the superomarginals, bears relatively few and considerably scattered spines; there are two series of actinolateral plates and spines which extend more than three-fourths of the arm-length, and the plates of the inner series often bear 2 spines; the inferomarginal spines are very conspicuous, $5-7 \mathrm{~mm}$. long and $2 \mathrm{~mm}$. wide at tip, thick, heavy and deeply grooved on the actinal side at tip; the characteristic large, slender pedicellariæ are exceedingly abundant, especially along the ambulacral furrows and about the mouth. The small specimens (dry) are brownish-yellow, but the largest (dry) is dull purplish-gray abactinally with a decided red tinge, that suggests the possible natural colour. Thirteen specimens.

Locs.-Oyster Bay, Tasmania, 20-40 fathoms.

East of Babel Island, Bass Strait, 65-70 fathoms.

Shoalhaven Bight, New South Wales, 15-45 fathoms.

South of Gabo Island, Victoria, 200 fathoms.

Southern coast of South Australia.

\section{Coscinasterias gemmifera (Perrier).}

(Plates xxxi.-xxxii.)

Asteracanthion gemmifer, Perrier, Ann. Sci. Nat., Zool., (5), xii., 1869, p. 237.

Coscinasterias gemmifera, Fisher, Ann. Mag. Nat. Hist., (7), xvii., 1906, p. 574.

This species was described from a specimen in Paris, reported to have come from Chili. Sladen, in the "Challenger" Report, listed a specimen, without comment, from the reefs at Kandavu, Fiji! Now comes this third specimen from Tasmania! So far as I can judge from Perrier's description and Sladen's "key," the fine, large 11-rayed individual, figured herewith, represents $C$. gemmifera but I do not believe the differences between Perrier's species and Gray's $C$. calamaria are worth much. If $C$. gemmifera really occurs in Chili and Fiji and C. Calamaria really is found at Mauritius (as reported), we have a very notable case of distribution, which deserves critical study.

Loc.-Oyster Bay, Tasmania, 20-40 fathoms. 
Family BRISINGID A.

Genus Odinta, Perrier.

Odinia aUSTRalis, ${ }^{1} s p$. nov.

(Plate xxvii., fig. 1-2.)

Rays 14. $R=100 \mathrm{~mm}$. ; $\mathrm{r}=8 \mathrm{~mm}$. $\mathrm{R}=12.5 \mathrm{r} . \mathrm{Br}=$ $2.5 \mathrm{~mm}$. Br where arm is widest (about $13 \mathrm{~mm}$. from centre of disk) $5 \mathrm{~mm}$. ; at middle of arm, about $2 \mathrm{~mm}$. Disk distinctly elevated above arm-bases, thickly plated, the plates without any definite arrangement but bearing minute pointed spinelets and countless pedicellariæ; papulæ very numerous, but usually, if not always single. Bases of arms, connected by marginal plates for only $2-3 \mathrm{~mm}$. beyond the disk. Arms narrow at base, then suddenly swollen and often about $10 \mathrm{~mm}$., gradually but quickly returning to the same width as at base ; as far as they are swollen, they are covered by plates, spinelets, papulæ and pedicellariæ like the disk, but beyond the swelling a thin skin crowded with minute pedicellariæ is their only covering. Along each side of arm is a series of vertical plategroups (apparently not more than 3 plates to a group distally), occurring at intervals of $2-3 \mathrm{~mm}$. or about 3 adambulacral plates; on the swollen basal portion of arm these series extend to medioradial line and the two of opposite sides may unite to form a very narrow band across the arm, but these bands are often incomplete, much bent or otherwise irregular ; they are faintly indicated distal to the swollen region but only for a short distance. The first 2 or 3 of these bands carry no spines, only acute, conical spinelets dorsally like those on the neighbouring abactinal plates, but on the third or fourth band, the lowest plate (adjoining the adambulacral) carries a spine about a millimeter long; on succeeding bands this spine increases in length and at the middle of the arm and beyond is $4 \mathrm{~mm}$. long; on the fifth or sixth band a second spine, just above the first appears and it too increases in length but never quite equals the first; on the seventh or eighth vertical group (corresponding to the "bands") a third spine appears but this remains distinctly shorter than the other two ; in life, these spines are apparently covered with a loose membrane, which is densely clothed with minute pedicellariæe, but after capture, probably owing to the rough journey in the trawl, much of this membrane is commonly wanting. Adambulacral plates rather longer than broad; at base of arm, their armature consists of two spines, a very slender, acicular spine on the aboral end of the plate, with 2-3 minute pedicellariæ

1. Australis=southern; in reference to its being the first species of the genus to be taken in the Southern Hemisphere. 
near the tip, extending inwards horizontally directly across the ambulacral furrow, but not quite as long as the width of the furrow, and a stout, flattened spine, 2-3 $\mathrm{mm}$. long, with widened chisel-like tip, situated on the margin or actinal surface of the plate; this spine is more or less clothed on its outer side with a membrane densely covered with minute pedicellariæ. Beyond the middle of the arm the acicular furrow spine disappears, and the big marginal spine becomes smaller and smaller and steadily more acicular until at tip of arm, it is very minute or perhaps wanting. Oral plates each with 3 short (scarcely a millimeter long), blunt spines, one on the inner corner, one (the largest) on the outer corner, and the smallest at the aboral, radial corner; all carry a few minute pedicellarix. Madreporites apparently 4, very small and with few, short, wide furrows; they are more or less elevated and near margin of disk, but are difficult to make out in an undried specimen. Colour (alcoholic or dry), dingy yellowish-white. Two specimens.

This is a notable species, one of the "Endeavour's" most interesting captures, since it is the first member of the genus to be taken in the Southern Hemisphere and except the recently discovered Hawaiian species, the only species not from the Atlantic. The genus must henceforth be recognised as cosmopolitan, for the present form can hardly be considered generically different from the others although its specific characters are well-marked. The occurrence of several madreporites is an unusual feature and the adambulacral furrow spine is also characteristic. Finally it is worthy of remark that no other species of Odinia has been taken in water as shallow as 200 fathoms.

Loc.-South-east of Cape Everard, Victoria, 200 fathoms.

\section{OPHIUROIDEA}

The Ophiurans collected by the "Endeavour" are not an extraordinary lot in any particular, but they give added weight to the view that the Australian Ophiuran fauna is relatively poor. Up to the present about one hundred and fifteen species of Ophiurans have been recorded from Australia in three hundred fathoms or less, but fully half of these are known only from the far northern and north-western coasts of the continent, and are East Indian rather than Australian. Whitelegge lists only thirty-four Ophiurans from Port Jackson and neighbourhood, and six of these are from 
water four hundred fathoms or more in depth, while half a dozen others are of doubtful authenticity. The "Endeavour" collection contains three hundred specimens of twenty-six species, of which five are new to science and three have not previously been recorded from Australia. There are several other species, previously known from the Torres Strait region which are now recorded for the first time from southern Queensland or New South Wales. Undoubtedly the best feature of the collection is the notable series of Astroconus australis, but all the Trichasterids and Gorgonocephalids are of great interest. The complete absence of ten or a dozen well-known Port Jackson brittle-stars is rather remarkable. Of the one hundred and twenty-three Ophiurans now known from Australia, at least sixty are not known from elsewhere.

\section{Family OPHIOMYXIDE. \\ Genus Oрніомуха, Müller and Troschel.}

OPHIOMYXA AUSTRALIS, Lütken.

Ophiomyxa australis, Lütken, Add. ad. Hist. Oph., pt. iii., 1869 , p. 45.

These specimens range in disk-diameter from 15 to $25 \mathrm{~mm}$. Several have the arms more or less distinctly banded, indicating a diversity of colour in life similar to that shown by the West Indian species, O. flacirda. Fourteen specimens.

Locs.-Twenty miles east-south-east of Tasman Head, Tasmania, 80-85 fathoms.

East of Maria Island, Tasmania, 78 fathoms.

North-east of Cape Pillar, Tasmania, 80 fathoms.

Forty miles west of Kingston, South Australia, 30 fathoms.

\section{Genus OpHiobyrsa, Lyman. \\ OPHIOBYRSA RUDIS, Lyman.}

Ophiobyrsa rudis, Lyman, Bull. Mus. Comp. Zool. Harvard, v., 1878, p. 131.

This is a good series of this relatively little-known species, but they exhibit little diversity. The disk-diameter ranges from 9 to $27 \mathrm{~mm}$. The colour is yellow-brown of diverse shades, the arms often with narrow darker bands. Seven specimens.

Locs.-East of Maria Island, Tasmania, 78 fathoms. 
East of Babel Island, Bass Strait, 65-70 fathoms.

Off Gabo Island Victoria, 200 fathoms.

Between Gabo Island, Victoria, and Disaster Bay, New South Wales, 50-100 fathoms.

Off Twofold Bay, New South Wales, 30 fathoms.

\section{Genus Asteronyx, Müller and Troschel. Asteronyx LOVEni, Müller and Troschel.}

Asteronyx loveni, Müller and Troschel, Sys. d. Ast., 1842, p. 119.

The occurrence of this cosmopolitan species south-east of Australia is notable since its known range southward is thus extended over two thousand miles. The specimens are all small, 10-20 mm. disk-diameter, and, so far as I ean see, do not differ from North Pacific specimens of the same size. Six specimens.

Locs.-East of Babel Island, Bass Strait, 65-70 fathoms.

Off Gabo Island, Victoria, 200 fathoms.

South-east of Cape Everard, Victoria, 200 fathoms.

\section{Genus EURYaLe, Lamarck.}

EURYALE ASPERA, Lamarck.

Euryale aspera, Lamarck, Anim. sans Vert., ii., 1816, p. 538.

This species was taken by the "Challenger" in Torres Strait, but the present collection extends the known range southward over a thousand miles. All the specimens are dried adults, the disk-diameter only ranging from 25 to $40 \mathrm{~mm}$. There is considerable diversity in colour, however, for the specimen from Wide Bay is orange above, paling to yellow beneath; one from off Double Island Point is deep orangebrown; another is brown and another pale brown; the specimen from Port Curtis is very pale brown; all the other specimens are dull purple. Fourteen specimens.

Locs.-Twenty-five miles south-east of Double Island Point, Queensland, 33 fathoms.

Wide Bay, Queensland, 18-23 fathoms.

Port Curtis, Queensland, 14-16 fathoms. 
Genus OpHIocreas, Lyman.

Ophiocreas phanerum, ${ }^{1} s p$. nov.

(Plate xxxiii., fig. 1-2.)

Disk $18 \mathrm{~mm}$. in diameter ; arms $380 \mathrm{~mm}$. long ; arms about 20 times the disk-diameter. Disk and arms encased in a smooth, thick skin, which even when dry, shows no sign of calcareous plates or granules and more or less conceals the radial shields and arm-joints. In young specimens the skin is, of course, much thinner and when dry conceals very little. Radial shields narrow and convex, not closely approximate in pairs ; in young specimens, they are flat and are in rather closely joined pairs. Genital slits small (about $3 \mathrm{~mm}$. long), deeply sunken. Tentacle-pores quite small ; first 2 pairs on arm, naked ; succeeding pores, all guarded by a pair of short, flattened, rough spines; where largest (at about middle of arm) the inner spine is $2 \mathrm{~mm}$. long, $.80 \mathrm{~mm}$. wide, pointed and prickly for more than half its length; the outer is $1.5 \mathrm{~mm}$. long by $.45 \mathrm{~mm}$. wide and neither as flat, nor as pointed, nor as rough as the inner. The skin of the side of the arm encases the basal half of the spines and so forms a thin but conspicuous wall along each side of the lower surface of the arm ; this occurs in many if not all species of Ophiocreas. Basal arm-tentacles not encased in cuticular tubes. Teeth only 6 , triangular and very thick; no tooth papillæ or oral papillæ in the adult; in young specimens, a very few tooth papillæ are present. Colour (in alcohol or dry), deep red-purple; young specimens somewhat lighter. Fourteen specimens.

This species can be distinguished at a glance from any Ophiocreas, of which I know, by the remarkably short and flattened tentacle-scales or arm-spines and the small number of teeth. Although the young specimens (disk $=7 \mathrm{~mm}$; arms about $90-100 \mathrm{~mm}$.) were taken much further north than any of the adults, I see no reason to feel any doubts as to their identity, the short arm-spines are so characteristic. The chief growth-changes appear to be the thickening of the skin, the entire loss of tooth-papillæ and the separation and convex thickening of the radial shields. In a specimen with diskdiameter $13 \mathrm{~mm}$., these changes are complete.

Locs.-Twenty miles off Cape Barren, Cape Barren Island, Tasmania, 70 fathoms.

East of Flinders Island, Bass Strait, 80-300 fathoms.

Eastern Slope, Bass Strait, 70-100 fathoms.

Eight miles east of Sandon Bluffs, New South Wales, $35-40$ fathoms.

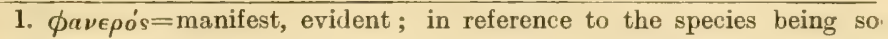
well characterised. 


\section{OpHIOCReas SIBOg E, Koehler.}

Ophiocreas Siboga, Koehler, Ophiures de l'Exped. du Siboga, i., Ophiures de Mer Profonde, 1904, p. 165.

It is not without some hesitation that I refer these seven specimens to this East Indian species, after comparing them with a cotype of $O$. siboga. The most obvious difference is in colour, the cotype being uniformly yellow and the Australian specimens reddish flesh-colour with a more or less heavy purple cast. This difference, however, must be disregarded since Koehler gives the colour of $O$. siboge as "reddish-purple violet," not altogether unlike the Australian material, apparently. Other differences, somewhat intangible, though noticeable when the specimens are side by side, I believe may properly be referred to individual diversity. The "Endeavour" specimens are all adult and are in fine condition; the largest has the disk $25 \mathrm{~mm}$. across and the arms $610 \mathrm{~mm}$. long. This is, I believe, much the largest specimen of Ophiocreas yet recorded. Although this species and the preceding (O. phanerum) were both taken east of Flinders Island, 80300 fathoms, I do not infer from this record that they occurred in the same haul of the trawl, but of course it is possible they did. They are so obviously unlike in their arm-spines (tentacle-scales) and teeth, that they cannot be confused, even if taken together.

In regard to the use of the generic name Ophiocreas, I regret to see that Döderlein and Matsumoto treat it as a synonym of Asteroschema. While it is probable that the old line of division between the two genera is not by itself valid, I think it is practically certain that we are dealing with two natural groups which ought to be kept separate. I therefore propose to continue the use of Ophiocreas for species like $O$. phanerum and $O$. sibogæe, and of Asteroschema for species like oligactes (Pallas), even though I am not yet prepared to define either genus accurately.

Locs.-East of Flinders Island, Bass Strait, 80-300 fathoms. Great Australian Bight, $129^{\circ} 6^{\prime} 30^{\prime \prime}$ E., 200-300 fathoms.

\section{Family GORGONOCEPHALIDA.}

Genus Asteroporpa, Lütken.

Asteroporpa australiensis, H. L. Clark.

Asteroporpa australiensis, H. L. Clark, Mem. Austr. Mus., iv., 11, 1909, p. 547.

This is a nice series of this interesting species, the diskdiameters ranging from about 7 to nearly $18 \mathrm{~mm}$.; in the 
largest specimen the arms apparently exceed $75 \mathrm{~mm}$. There is little diversity shown in colour or in any other feature. Ten specimens.

Locs.-South of Babel Island, Bass Strait, 92-160 fathoms.

East of Babel Island, Bass Strait, 65-70 fathoms.

Off Gabo Island, Victoria, 200 fathoms.

South of Gabo to south-east of Cape Everard, Victoria, 70-80 fathoms.

Genus Conoclades, H. L. Clark.

Conocladus amblyconus, H. L. Clark.

Conocladus amblyconus, H. L. Clark, Mem. Austr. Mus., iv., 11, 1909, p. 549.

This interesting series, with disk-diameter ranging from $12-40 \mathrm{~mm}$. is not quite so diversified in size as that taken by the "Thetis," but in the number and distribution of the rounded tubercles on disk and arm-bases, it shows more diversity. The colour is also notable, some specimens being almost white, and others purplish-brown, while the remainder are fawn-colour. There is no indication of any intergradation with any other species, the distinctive characters being perfectly plain in all the twenty-one specimens.

Locs.-Between Port Stephens and Newcastle, New South Wales, 22-60 fathoms.

Shoalhaven Bight, New South Wales, 15-45 fathoms.

Off Twofold Bay, New South Wales, 30 fathoms.

\section{Conocladus oxyconus, H. L. Clark.}

Conocladus oxyconus, H. L. Clark, Bull. Mus. Comp. Zool. Harvard, lii., 1909, p. 132.

The individuals from Shoalhaven Bight, New South Wales, are very similar to the originals from off Port Jackson, and call for no special comment. The specimen from South Australia was taken with a specimen of the next species (Astroconus australis) and owing to the locality was at first identified as Astroconus. Critical study has, however, convinced me that if Conocladus oxyconus and Astroconus australis are to be maintained as distinct species, this South Australian individual must be called Conocladus. But $C$. 
oxyconus is not otherwise known from south or west of Shoalhaven Bight, and I must confess that the occurrence of this specimen taken off Cape Wiles, South Australia, with an undoubted Astroconus has shaken my faith in the distinctness of the two forms. I should like to believe that the specimen under discussion was wrongly labelled, but I cannot see the slightest reason for such a belief. The question of the relationship of Astroconus and Conocladus is thus reopened and will be discusseel further under the next species, but it is worth noting here that up to the present time only eight specimens of $C$. oxyconus are known and two of these are from unknown localities, though there is reason to think they are from near Port Jackson; of the other six, two are known to be from off Port Jackson, one is from Coogee, two from Shoalhaven Bight and one from south of Cape Wiles, South Australia. Of forty specimens of $C$. amblyconus now known, all are from New South Wales, while all known specimens of Astroconus are from Bass Strait southward and westward. Evidently Conocladus is the more northern genus and $C$. oxyconus is much the rarest of the three species.

Locs.-Shoalhaven Bight, New South Wales, 15-45 fathoms. Two specimens.

Fifteen miles south of Cape .Wiles, South Australia.

Genus Astroconus, Döderlein.

Astroconus aUSTRALIS (Verrill).

Astrophyton australe, Verrill, Bull. U.S. Nat. Mus., iii., 1876, p. 74 .

Astroconus australis, Döderlein, Abh. math-phys. Klasse K. Bayer Akad. Wissensch., ii. Suppl.-Bd., 5, 1911, p. 37.

This is a remarkable and highly interesting series of this little known species. The fifty-five specimens range in size from young ones, with disks $11-12 \mathrm{~mm}$. in diameter to large adults, whose disks are $45-50 \mathrm{~mm}$. across. Two are perfectly tetramerous. The colour is notably diversified, ranging from nearly uniform pale gray or almost white, through pale gray prettily marked with dull red-purple, to dark gray heavily marked with purplish; or the ground colour may be yellowish-brown, light or dark, either without markings of red-purple, or prettily marked with that shade; many individuals have the arms very regularly banded with the red-purple, but in others there are only 
a few dots or no markings at all. Diversity is equally marked in other features. The distance of the first armfork from the distal end of the radial shields ranges from .25 of the radial shield length to 1.10 ; or the same fact may be expressed in another way by saying there are from 9 to 15 arm-joints in the undivided arm-base. The number of armdivisions ranges from 6 to 10 or more. Most of the specimens show the radial shields well separated, and the disk has distinct interradial areas, but there is a tendency on the part of some individuals to have the radial shields united in pairs by thick, concealing skin and in such cases the interradial areas are much reduced; thus the condition, characteristic of Conocladus, is approached. Further resemblance to Conocladus is brought about in certain specimens by the large size of the disk spines. In typical $A$. australis, these spines are about a millimeter high, conical, and the thickness at base about equals the height; they are present chiefly on the radial shields and are often confined to them ; in many specimens they are smaller and more numerous, and rarely they are reduced to low, inconspicuous tubercles. But in some cases, notably in some South Australian specimens, the spines are $1.5 \mathrm{~mm}$. high and correspondingly stout. In these cases, too, the spines on the basal parts of the arms are larger than usual and the resemblance to Conocladus may be quite marked. Nevertheless none of the specimens have the radial shields completely united into five disk-wedges, with very much reduced interradial areas as in Conocladus, nor do any have spines on disk and arm-bases really as big as in that genus. For these reasons one can, without difficulty, separate specimens of the two genera, but I am not sure that the separation is not an arbitrary rather than a natural one. I have previously expressed the belief that Conocladus is derived from Astroconus, while Döderlein thinks the reverse to be the case. Which of us is correct can only be determined by a study of growth-changes in much younger specimens than any at present available. But the youngest specimens in the present series are not at all Conocladus-like, the radial shields being narrow and widely separated, the interradial areas large and the disk spines few and small. It is quite possible that further study and more abundant material will show that Conocladus oxyconus is only an extreme form of Astroconus australis, and not a separate species. In that case the genus Conocladus will need a new name, i.e., the species amblyconus and microconus, for the name Conocladus will have to replace Astroconus as the generic name of Verrill's Astrophyton australe, since it has the same type and antedates Astroconus by two years. In any case, whether $C$. oxyconus is specifically different from 
Astroconus australis or not, it does not seem to me possible to draw a subfamily distinction between them, as Döderlein does, and place one in the Astrochelinx and the other in the Gorgonocephalinæ. If these two groups are worth distinguishing as subfamilies, I think Conocladus must certainly be put in the Gorgonocephalinæ.

Locs.-Thirty-five miles south-east of Bruni Island, Tasmania, 150-230 fathoms.

North-east of Cape Pillar, Tasmania, 50-80 fathoms.

Bay of Fires, Tasmania, 40 fathoms.

Twenty miles east of Babel Island, Bass Strait, 35 fathoms.

Between Devonport and Launceston, Tasmania.

Eastern Slope, Bass Strait, 70-100 fathoms.

Off Gabo Island, Victoria, about 200 fathoms.

Thirty-six miles N. $58^{\circ}$ E., of Cape Wickham, King Island, Bass Strait.

South-east coast of Australia.

Coast of Victoria.

Forty miles west of Kingston, South Australia, 30 fathoms.

Off Murray River mouth, South Australia, 17 fathoms.

Sanders Bank, Kangaroo Island, South Australia, 28 fathoms.

Fifteen miles south of Cape Wiles, South Australia.

Fifty miles south of Cape Wiles, South Australia, 75 fathoms.

South-east of Flinders Island, South Australia, 37 fathoms.

Fifteen miles south of St. Francis Island, South Australia, 30 fathoms.

\section{Genus Astrodendrum, Döderlein.}

Astrodendrum PUSTUlatum, ${ }^{1} s p$. nov.

$$
\text { (Plate xxxiv., fig. 1-2.) }
$$

Disk diameter, $40 \mathrm{~mm}$.; arms, divided about 8 times, approximately $225 \mathrm{~mm}$. long, measured from mouth; one arm measured as follows, by divisions, the figures, however, being only approximate : from mouth to first fork, $20 \mathrm{~mm}$.; second division, $12 \mathrm{~mm}$.; third, $13 \mathrm{~mm}$.; fourth, $30 \mathrm{~mm}$.;

1. Pustulatus =having blisters or pustules ; in reference to the pimple like elevations on the disk. 
fifth, $30 \mathrm{~mm}$. ; sixth, $27 \mathrm{~mm}$. ; seventh, $37 \mathrm{~mm}$. ; eighth, 30 $\mathrm{mm}$.; and ninth, $25 \mathrm{~mm}$. Radial shields distinct, well separated, but in pairs ; distance between distal ends of a pair, $6 \mathrm{~mm}$. ; width of shield at distal end, $3 \mathrm{~mm}$. ; distance between distal ends, across an interradius, $12 \mathrm{~mm}$. Disk covered by a smooth, thick skin without calcareous plates, even at margin ; all over the surface, but chiefly along the radial shields, are scattered minute, pimple-like elevations, not at all crowded, but where thickest there may be 7 or 8 in a space $3 \mathrm{~mm}$. square; large parts of the surface, especially near margin have none. Oral surface covered by the same smooth, thick, non-calcified skin, but with no pustules. Madreporite single, small, but distinct. Genital slits only $5 \mathrm{~mm}$. long, but very distinct. Teeth and teeth-papillæ indistinguishable, rather flat, about three times as long as wide. Mouth-papillæ none. First tentacle pore of arm without any protecting scale ; succeeding pores of basal portion of arm with two small peg-like scales; on first division of arm, there are three scales to each pore, the inner one nearly a millimeter long and .50-.66 $\mathrm{mm}$. thick, the second about as long, but more slender, the outer distinctly smaller in every way; all three have rough, prickly tips when dry. Distally the outer spine disappears and then the second, while the inner one becomes transformed into the characteristic hook. The half-circles of hooklets are very narrow, consisting of only 2 series of granules; they are incomplete on the second arm-division and on the first are represented only by little patches; on the third and distal thereto they are complete. Colour (in alcohol) nearly uniform reddish fleshcolour; the pustules and tentacle-scales are somewhat darker.

This species is easily distinguished from either of the other species in this restricted genus by the characteristic diskcovering and the tentacle-scales. It is so utterly unlike any other known Australian euryalid that there is no possibility of confusion with any of them.

Loc.-East of Flinders Island, Bass Strait, 100-300 fathoms.

\section{Genus Astrothamnds, Matsumoto.}

Astrothamnus Rugosus, ${ }^{1} s p$. nov.

(Plate $\times x x v .$, fig. 1-2.)

Disk $20 \mathrm{~mm}$. in diameter; arms 5, approximately $140 \mathrm{~mm}$. long, but the tips are so closely spirally coiled, it is not possible to measure them exactly. Disk covered by coarse, rounded

1. Rugosus =rough; in reference to the rough character of the diskcovering. 
granules $.30-.90 \mathrm{~mm}$. in diameter, among which are a few insignificant, minute plates; the granules are low, hemispherical, with rough, or prickly surface. Radial shields approximate in pairs, $10-12 \mathrm{~mm}$. long by $2-2.5 \mathrm{~mm}$. wide distally, more or less concealed. Arms sharply distinct from disk, the dorsal surface and sides covering by alternating half-circles of glassy hook-bearing, and opaque, smooth granules; the half-circles are not at all sharply defined under a lens but nevertheless give an appearance of fairly uniform annulations. Genital slits only about $2 \mathrm{~mm}$. long, but quite wide. Madreporite small but very distinct, just outside the mouth frame ; in the holotype, there are two, not in adjoining interradii, but one is evidently smaller and out of place. Oral surface and lower surface of arms, uniformly and finely granulated. Teeth, teeth-papillæ and mouth-papillæ numerous, similar, spiniform ; teeth somewhat larger in every way than the others. First tentacle-pore of arm with 3 or 4 short, stout, spinulose tentacle-scales; second with 6 or 7 , third with 8 , succeeding pores with 8,9 or 10 , nearly to middle of arm, when the number begins to drop rapidly and the scales become more and more like the hooks on the lower ends of the half-circles of hooks, until at the tip of the arm the tentaclescales are no longer distinguishable. Colour (in alcohol), brownish-yellow; when dry, considerably lighter. Four specimens.

This is a very distinct species, remarkable for the large number of tentacle-scales. The disk covering too is characteristic, obviously different from that of any of the previously known species. The genus is an East Indian one, reaching Sagami Bay, Japan, on the north and now shown to reach: Tasmania on the south. The specimens from off Cape Everard, Victoria, are only $9 \mathrm{~mm}$. across the disk and the maximum number of tentacle-scales seems to be 7 .

Locs.-East of Flinders Island, Bass Strait, 80-300 fathoms. South-east of Cape Everard, Victoria, 200 fathoms.

Family OPHIACANTHID $\approx$.

Genus Ophiacantha, Müller and Troschel.

Ophiacantha heterotyla, H. L. Clark.

Ophiacantha heterotyla, H. L. Clark, Mem. Austr. Mus., iv., 11,1909 , p. 542 .

This is a little individual, not $3 \mathrm{~mm}$. across the disk, but there seems no. doubt of its identity.

Loc.-Between Devonport and Launceston, Tasmania. 
SEA LILIES, STARFISHES, ETC-CLARK.

Family AMPHIURIDA.

Genus OpHiactis, Lütken.

Ophiactis luteomaculata, $H$. L. Clark.

Ophiactis luteomaculata, H. L. Clark, Mem. Mus. Comp. Zool. Harvard, xxv., 1915.

These specimens were all taken from the large spines of a Sea-urchin (Prionocidaris australis) and as a rule, they were more or less hidden in Barnacles (Acorn-shells) growing thereon. The species was hitherto known only from the holotype taken at the Murray Islands, Torres Strait, in a large sponge. None of the present series is quite so large as the original but they show little structural divergence. The smallest specimens have 6 arms and are clearly reproducing by fission, but the adults are symmetrically 5-rayed. All the specimens are dry and their colours are dull but the adults have the arms pinkish and more or less distinctly banded. The radial shields are not of a different colour from the rest of the disk. An excellent specific character is a dark band or spot at the middle of the larger arm-spines; all these specimens show it.

Loc.-Eleven miles south-east of Ballina, New South Wales, 27-29 fathoms. Eleven specimens.

Ophiactis Resiliens, Lyman.

Ophiactis resiliens, Lyman, Bull. Mus. Comp. Zool. Harvard, vi., 1879 , p. 36.

One of the individuals from off Kingston, South Australia, (disk-diameter, $6 \mathrm{~mm}$.) has all the upper arm-plates broken into 2 or 3 pieces. The other specimens, with disk-diameters of 3.5 and $5.5 \mathrm{~mm}$. respectively, are not peculiar. It may be noted, however, that the species has not previously been known from west of Bass Strait. Three specimens.

Locs.-Forty miles west of Kingston, South Australia, 30 . fathoms.

Off Cape Martin, South Australia, 21 fathoms. 


\section{OPHIACTIS SYMBIOTA, ${ }^{1} s p$. nov.}

(Plate xxxvi., fig. 1-2.)

Disk $6.5 \mathrm{~mm}$. in diameter; arms about $26 \mathrm{~mm}$. long. Disk covered by a coat of 150-200 rather coarse, flat, rounded scales, the largest of which are near centre and the smallest near interradial margins; between these plates or on their corners or edges are low, conical tubercles which increase in length near the interradial margins, becoming short sharp spinelets; these tubercles and spinelets are not very numerous, some plates having none, while the largest plates have only 5-6 around them. Radial shields small, about $1 \mathrm{~mm}$. long by $.5 \mathrm{~mm}$. wide, well separated within but sometimes in contact distally. Upper arm plates, fan-shaped, truncate proximally, strongly convex distally, with lateral corners more or less rounded or truncate. Interbrachial areas below covered like the interradial margins of disk, with rather small scales and numerous sharp spinelets. Oral shields pentagonal, widest proximally, disto-lateral sides concave, distal side shortest; madreporite very much larger than other four and more iso-pentagonal. Adoral plates large, twice as long as broad, curved, meeting broadly within. Teeth about 6, squarish; below the lowest is a very small, triangular dental papilla. Oral papilla apparently 2 on a side but the proximal may be the scale of the inner oral tentacle-pore; distal papillæ nearly circular, about .20 mm. in diameter ; proximal, a trifle smaller and more angular. First under arm-plate relatively large, longer than wide, in contact with second, thus broadly separating the adoral plates; succeeding plates tetragonal, wider than long, with distal margin slightly convex and lateral margins concave, becoming, beyond the middle of arm, pentagonal with a proximal angle and longer than wide ; first 5 or 6 barely in contact. Side arm plates rather large meeting above and below at middle of arm and beyond ; each carries 4 , or usually 3 , opaque, stout, blunt spines ; uppermost longest, about $1 \mathrm{~mm}$. long; lowest, shortest, about .60 $\mathrm{mm}$. long. Tentacle-scale single, moderately large, at side of lower arm-plate. Colour (dry), brownish-white.

This interesting Ophiuran, I found on a specimen of Comanthus plectrophorum, clinging closely to the oral surface of the disk. Its position leaves little doubt in my mind that it was commensal with the Crinoid in life, as a number of species of Brittle-stars are known to be. It is utterly unlike $O$.

1. $\sigma v \mu \beta \iota$ ó $^{2}=$ =living with; in reference to the apparently symbiotic habits. 
resiliens in its general appearance and I at first thought it to be an Ophiolebes, but the mouth parts seem to be undoubtedly those of an Ophiactis and I therefore have referred it to this genus without dissection. The oral surface is rather markedly like Ophiactis abyssicola but the disk-covering is utterly unlike that species, and is indeed the distinguishing specific character. The short arms, few stout arm-spines and pair of oral papillæ are additional features worthy of emphasis.

Loc.-East of Flinders Island, Bass Strait, 100-300 fathoms.

Genus Amphiura, Forbes.

Amphiura Constricta, Lyman.

Amphiura constricta, Lyman, Bull. Mus. Comp. Zool. Harvard, vi., 1879, p. 22.

These specimens are all smaller than Lyman's type and as a rule have only 4 or 5 arm spines, but on a few basal arm joints of the largest specimen (disk diameter, $4 \mathrm{~mm}$.) there are 6 spines. The type locality was Port Jackson, New South Wales, and there is a specimen in the Museum of Comparative Zoology from Westernport, Victoria. The "Endeavour" specimens thus extend the known range considerably to the westward. Three specimens.

Locs.-Forty miles west of Kingston, South Australia, 30 fathoms.

Off Cape Martin, South Australia, 21 fathoms.

\section{Family OPHIOTRICHD $\mathrm{E}$.}

\section{Genus ОрніотнRіх, Müller and Troschel.}

\section{OPHIOTHRIX ARISTULATA, Lyman.}

Ophiothrix aristulata, Lyman, Bull. Mus. Comp. Zool. Harvard, vi., 1879, p. 50.

These specimens range from 5 to $18 \mathrm{~mm}$. in disk-diameter and make a fine series of this handsome Brittle-star. The colour ranges from nearly white to rosy pink; the spines are always white or colourless Two of the large individuals are beautifully though sparsely spotted with bright brown. There is a broad longitudinal stripe on the upper side of the arms, in one large specimen deep pink, but usually pure white. It seems to be lacking in the specimen from Oyster Bay, 
Tasmania, and this individual is also peculiar in the large number of disc scales and the short, thorny disk spines; the disk-diameter, however, is only $6.5 \mathrm{~mm}$., and I believe the peculiarities are associated with youth. The smallest specimen is from east of Maria Island, Tasmania, and still retains the large, transparent central plate of the disk, known to be characteristic of the very young of some other species of Ophiothrix; its disk spines are quite thorny and relatively rather short. Nineteen specimens.

Locs.-Twenty miles south-east by east of Tasman Head, Tasmania, 80-85 fathoms.

East of Maria Island, Tasmania, 78 fathoms.

Entrance to Oyster Bay, Tasmania.

East of Babel Island, Bass Strait, 65-70 fathoms.

Off Gabo Island, Victoria, 200 fathoms.

\section{OPHIOTHRIX CESPITOSA, Lymain.}

Ophiothrix coespitosa, Lyman, Bull. Mus. Comp. Zool. Harvard, vi., 1879, p. 53.

These specimens range in disk-diameter from 1.5 to $6 \mathrm{~mm}$, and in colour from bright reddish-pink to purplish-gray, brownish-yellow and nearly white. The disk covering shows much diversity also, ranging from a uniform covering of minute thorny, somewhat stellate stumps, which even conceal the radial shields, to one where the thorny stumps are very largely replaced by rough spinelets and the radial shields are more or less bare; there are many intermediate stages. The upper arm plates and the arm spines are more uniform, but not perfectly so. I cannot see that there is any correlation between the characters mentioned and the locality whence the specimen came. The seven specimens from off Ballina, New South Wales, were all found on the abactinal surface of a Sea-urchin (Prionocidaris australis); they are all young and are bright reddish-pink, except two which have pale pink arms and a light coloured disk hardly tinged with pink. In view of the well-known instability of characters in the genus, and the present multiplicity of species, I think it best to regard all the specimens as $O$. coespitosa and leave it for some future worker in Australia to determine whether $\mathrm{J}$ am right. Forty-one specimens. 
Locs.-Twenty-three miles east-south-east of Round Hill Head, Queensland.

Nine miles east of Fraser Island, Queensland.

Eleven miles south-east of Ballina, New South Wales, 27-29 fathoms.

Eight miles east of Sandon Bluffs, New South Wales, 35-40 fathoms.

Forty miles west of Kingston, South Australia, 30 fathoms.

Sanders Bank, Kangaroo Island, South Australia, 28 fathoms.

Fifteen miles north-west of Cape Jervis, South Australia, 17 fathoms.

OPHIOTHRIX FUMARIA, Müller and Troschel.

Ophiothrix fumaria, Müller and Troschel, Sys. d. Ast., 1842, p. 113 .

This is a well-preserved individual with disk $9 \mathrm{~mm}$. across, agreeing in all essentials with a specimen of $O$. fumaria identified by Mr. Lyman many years ago, which was purchased in Hamburg and was reported to have come from the East Indies. The type locality of the species is stated by Müller and Troschel to be unknown.

Loc.-Seven miles south-south-east of Double Island Point, Queensland.

\section{OPHIOTHRIX NEREIDINA (Lamarck).}

Ophiura nereidina, Lamarck, Anim. sans Vert., ii., 1816, p. 544 .

Ophiothrix nereidina, Müller and Troschel, Sys. d. Ast., 1842 , p. 115.

Although small, only $4 \mathrm{~mm}$. across the disk, these are typical examples of this beautiful species. They are chiefly of interest in that they extend the known range of the species many hundreds of miles to the south. Two specimens.

Loc.-Nine miles east of Fraser Island, Queensland. 


\section{OPHIOTHRIX SPONGICOLA, Stimpson.}

Ophiothrix spongicola, Stimpson, Proc. Acad. Nat. Sci. Philadelphia, vii., 1855, p. 385.

These are typical specimens of this handsome and characteristically Australian species. It seems to me quite possible, however, that $O$. fumaria is really the proper name for this species, Müller and 'Troschel's type having very probably been brought to Paris from Port Jackson, but never having had a locality label. Koehler's careful description of it and his figures apply very closely to this species, more closely than to the specimen Mr. Lyman has called $O$. fumaria. In the ultimate revision of the genus, this matter should be given critical attention. Three specimens.

Locs.-Shoalhaven Bight, New South Wales, 15-45 fathoms.

Fifteen miles north-west of Cape Jervis, South Australia, 17 fathoms.

Genus Ophiothela, Verrill.

\section{OpHothela HAdRA, H. L. Clark.}

Ophiothela hadra, H. L. Clark, Mem. Mus. Comp. Zool. Harvard, xxv., 1915, p. 284.

This is another species, previously known only from the holotype taken at the Murray Islands, Torres Strait. The present series shows that the original was immature, and the arms are not unusually short and stout in adults, though the general form is rather robust. The largest specimen at hand is $3 \mathrm{~mm}$. across the disk and the arms are $10-11 \mathrm{~mm}$. long. Only the smallest specimens are as light as the holotype, all the larger specimens being prettily variegated with dull deep bluish, pink and pale cream-colour; the centre of the disk, the sides of the arms and the arm spines are pink; but there is some diversity. There is also some diversity in the armature of the disk, the larger interradial spine-like granules being often wanting. The oral shields are very small, nearly circular, white; adoral plates larger than oral shield, but quite similar in form and colour, perfectly smooth, in close contact with each other. There are $5 \mathrm{arm}$ spines at base of arm. The knobs on the upper arm plates are conspicuous. All of these specimens were taken from the primary spines of Sea-urchins (Prionocidaris australis); most of the smaller ones are reproducing by fission and have only 2,3 or 4 rays, but the adults are symmetrically 6-rayed.

Loc.-Eleven miles south-east of Ballina, New South Wales, 27-29 fathoms. 
SEA LILIES, STARFISHES, ETC.-CLARK.

\section{Family OPHIOLEPIDID $\approx$.}

Genus Amphiophiura, Matsumoto.

Amphiophiora COLLeta ${ }^{1}, s p . n o v$.

(Plate xxxvii., fig. 1-2.)

Disk $17 \mathrm{~mm}$. in diameter; arms all broken, but one is nearly $50 \mathrm{~mm}$. long and indicates a probable length of $55 \mathrm{~mm}$. or more. Disk covered by a coat of 21 large, flat, smooth scales and the 10 radial shields, between which, in the angles, are much smaller, more or less triangular scales; many of these little scales and some of the larger show a narrow, marginal border as though cemented down to the neighbouring plates; primary plates very distinct, about $2.5 \mathrm{~mm}$. across, but not conspicuous. Radial shields, $3-4 \mathrm{~mm}$. long and nearly or quite as broad, irregularly rounded triangular, smooth, the inner ends separated by a large scale, but the distal inner corner of one distinctly overlapping the corresponding corner of the other for more than a millimeter. Basal upper arm plate about twice as broad as long; second and third at least three times as broad as long; the succeeding 7 or 8 plates are tetragonal, wider than long, broadly in contact, with distal margin convex and much wider than proximal; beyond the tenth joint the upper arm plates tend to become triangular, as long as broad, and separated from each other, the condition they show on distal half of arm. Interbrachial areas below covered by the oral shield, a large marginal plate, wider than long and 5 smaller, somewhat swollen plates, between them. Genital plates large, more than a millimeter wide at the upper end, bearing an arm-comb of about 25 low, triangular papillæ, placed closely side by side ; there are no papillæ on the arm plates.

Oral shields oval, sharply pointed proximally, $4 \mathrm{~mm}$. long by $3 \mathrm{~mm}$. wide; adoral plates, short, three times as long as broad, meeting fully and closely within; oral plates larger than adorals, only slightly swollen. Teeth only 4 , triangular. Oral papillæ only 3 on a side, borne wholly on the oral plates; the innermost is like the teeth, but narrower, while the other two are very wide and notched like the molar teeth of a dog. Oral tentacle-pore (the second or distal one, of course) opens entirely outside mouth slit, at distal end of oral plate; its inner side is guarded by 4 papillæ, its outer by 6 . First under arm plate large, octagonal, much wider than long; second longer and narrower, hexagonal, about as long as wide ;

1. $\kappa \circ \lambda \lambda \eta \tau o ' s=$ glued together; in reference to the appearance of the disk plates. 
succeeding plates wider than long, more or less tetragonal, broadly in contact. Beyond the eighth or ninth joints the under arm plates are nearly or quite separated from each other, pentagonal with proximal angle, much wider than long; they keep this form to the end of the arm. Side arm plates rather large, but not conspicuous, well separated at base of arm, but broadly in contact distally; each carries 3 small arm spines, a minute, bluntly pointed, peg-like one on upper distal corner of plate (often wanting distally) and a pair of somewhat larger, more flattened spines, close to the lower distal corner of plate; except on one or two basal joints, none of the arm spines are as long as one-third the length of the side arm plates. Tentacle-pores rather larger; the basal ones have 3 or 4 scales on each side, but the number soon dwindles to one on the under arm plate and one on the side arm plate and near the middle of the arm, the former disappears. Colour (dry), yellowish-white.

This rather handsome species is well characterised by the peculiar oral papillæ, the arrangement of the arm spines, the shape of the papillæ in the arm-comb and the arrangement of the disk plates. In all these particulars, as well as in the shape of the under arm-plates it differs from $A$. ornata, which is one of its near allies, but except in the arrangement of the disk scales it is no nearer to $A$. undata, which is one of its nearest allies geographically. Its longer arms and very different arm-comb will distinguish it at once from $A$. ctenophora (H. L. Clark) taken by the "Thetis" off the coast of New South Wales.

Loc.-East of Babel Island, Bass Strait, 60-80 fathoms.

Family OPHIODERMATID $\mathrm{E}$.

Genus Pectinura, Forbes.

Pectinura dyscrita, $H$. L. Clark.

Pectinura dyscrita, H. L. Clark, Mem. Austr. Mus., iv., 11, 1909 , p. 534 .

This series of specimens has led me to question very much whether $P$. dyscrita can properly be distinguished from $P$. anchista, the Japanese species. But after comparing specimens of the same size, I have decided not to unite them at present. The arm spines in $P$. anchista are thinner, flatter and more pointed than in $P$. dyscrita. If similar specimens of Pectinura should hereafter be found in the Philippines or in the East Indies, it would probably result in including the 
Japanese and Tasmanian forms under the same name. The New Zealand species, $P$. cylindrica, is undoubtedly a very near relation but seems to be a smaller form, with arm spines and arm plates somewhat different. Lyman's $P$. arenosa from Bass Strait and Bell's $P$. assimilis from Port Jackson seem to be quite distinct, but it must be granted that the fire species form a very homogeneous group.

The "Endeavour" specimens show plainly that in $P$. dyscrita at least the relative as well as the actual arm-length increases markedly with age; in the smallest specimen the disk-diameter (D) is $10 \mathrm{~mm}$., the arm length (A) $40 \mathrm{~mm}$., and hence $\mathrm{A}=4 \mathrm{D}$, while in another $\mathrm{D}=12, \mathrm{~A}=60, \mathrm{D}=5 \mathrm{~A}$, and in the largest specimen, $\mathrm{D}=20, \mathrm{~A}=140, \mathrm{D}=7 \mathrm{~A}$. There is some diversity in colour indicated; the arms are often banded with brownish, or dirty whitish, and in one case there are 5 or 6 transverse bands, dorsally, of rose-purple. The colour in life is probably white, dull yellow, or pale brown, with rose-purple markings, spots or bands. Fourteen specimens.

Locs.-North-east of Cape Pillar, Tasmania, 80 fathoms.

East of Maria Island, Tasmania, 78-128 fathoms.

East of Babel Island, Bass Strait, 65-70 fathoms.

East of Flinders Island, Bass Strait, 80-300 fathoms.

Off Gabo Island, Victoria, 200 fathoms.

Family OPHIOCHITONID E.

Genus OpHIONEREIS, Lütken.

OPHIONEREIS SCHAYERI (Müller and Troschel).

Ophiolepis schayeri, Müller and Troschel, Arch. f. Naturg., x. i., 1844, p. 182 .

Ophionereis schayeri, Lütken, Add. ad Hist. Oph., pt. 2, 1859 , p. 110.

This is a very small specimen, only $4.5 \mathrm{~mm}$. across the disk, but it is not otherwise notable.

Loc.-Between Devonport and Launceston, Tasmania.

\section{ECHINOIDEA.}

The collection of Sea-urchins made by the "Endeavour" strengthens the evidence in support of the opinion formed by study of the "Thetis" collection, that Echini are relatively unusually common in the waters of Southern Australia. Considering the fact that there are rather more than one 
thousand four hundred species of Ophiurans known and that only twenty-six occur in the "Endeavour" collection, it is remarkable that twenty-nine species of Echini occur, with fewer than five hundred species known. Of these twentynine species, five are here described for the first time and five others are recorded for the first time from Australia. The most remarkable specimen is undoubtedly the adult individual of Echinus horridus, a species previously known from off the coast of Chili, but the fine series of Prionocidaris. australis, the handsome new Coelopleurus and the new Maretia are worthy of particular mention. Up to the present time about sixty species of Echini have been listed from Australia, but wrong identifications have been so numerous and misleading, the real number of species is very uncertain. Probably, including the ten here added to the list, there are at least sixty Australian Echini occurring in less than three hundred fathoms, thirty-five of which are peculiar to. Australia.

\section{Family CIDARID 2 .}

\section{Genus Phyllacanthus, Brandt.}

As regards the generic name Phyllacanthus, I have given fresh and careful attention to Brandt's paper, and I see no ground for rejecting his subgenera. Lambert and Thiéry ${ }^{1}$ have argued very strongly that these groups are invalid, but there seems to me a fundamental error in the argument which quite vitiates it. They assume that Brandt is revising and classifying all Echini, and hence when he gives three subgenera under the genus Echinus they assume that all the species of Echinus are to be placed in these three subgenera, and, of course, one would then have to be a synonym of Echinus. But such is not Brandt's intention. He is simply giving a classification of the forms noted by Mertens in his voyage; occasionally other species are mentioned for illustrative purposes, but there is no attempt to group all the known Echini. Under the circumstances, then, I do not see why Brandt's subgenera are not perfectly valid, certainly as much so as any genera of Echini that were proposed prior to 1846. Particularly in the case of Phyllacanthus, Brandt's course is clear; he had a large cidarid from the Bonin Islands to deal with; its peculiarities were obvious and are fairly well stated; for it he proposed a subgenus of Cidarites which he called Phyllacanthus, at the same time designating the species as $P$. dubia. The fact that he was planning for a full

1. Lambert and Thiéry-Bull. Soc. Sci. Nat. Haute Marne, vi., 23, 1909. 
classification of Echini (as he states in a footnote) and so suggests two sections for the subgenus and mentions certain of Lamarck's species of Cidarites in connection with them, does not so far as I can see affect the status of Phyllacanthus at all. It seems to me clear that the only generic name, except Cidaris (=Cidarites), which may be used correctly for dubia and imperialis, whether they are identical, as is generally believed, or not, is Phyllacanthus.

\section{Phyllacanthus imperialis (Lamarck).}

Cidarites imperialis, Lamarck, Anim. sans Vert., iii., 1816, p. 54 .

Phyllacanthus imperialis, Brandt, Prodrome, 1835, p. 268.

The test of this individual is about $45 \mathrm{~mm}$. in diameter and the longest spines are $60 \mathrm{~mm}$. long and $5 \mathrm{~mm}$. thick. It is undoubtedly an example of Tenison-Woods' $P$. parvispina, but I am not prepared to recognise the form by name yet. A good series of specimens from the Murray Islands in Torres Strait are all typical $P$. imperialis, so far as I can see, but all the New South Wales material I have examined has the slender spines of $P$. parvispina. The amount of available material from other regions is not sufficient to enable me to decide as yet on the worth of this character.

Loc.-Shoalhaven Bight, New South Wales, 15-45 fathoms.

Genus Prionocidaris, A. Agassiz.

Prionocidaris australis (Ramsay).

Phyllacanthus australis, Ramsay, Cat. Echinod. Austr. Mus., 1885 , p. 44.

Stephanocidaris bispinosa, A. Agassiz, Rev. Ech., pt. 1, 1872 , p. 160 (nomen nudum) ; pt. 3, Sept., 1873, p. 393 (NON Cidarites bispinosa, Lamarck, as described and figured by de Loriol, Mém. Soc. Sci. Nat. Neuchatel, v., May, 1873, p. 33).

Prionocidaris agassizii Döderlein, Abh. Senck. Naturf. Ges., xxxiv., 1911, p. 242.

This is a remarkable series of a very notable species. Döderlein (loc. cit.) has shown very clearly that the genus Stephanocidaris A. Ag. is a pure synonym of Goniocidaris and hence cannot be used for this species. He shows further that 
Mr. Agassiz's application of the name bispinosa to this species cannot be maintained since de Loriol's restriction of Lamarck's name to the species Mr. Agassiz called annulifera has several months' priority over Mr. Agassiz's selection. The latter being left thus without a name, Döderlein courteously proposed to call it agassizii. When at the Australian Museum in November, 1913, I was surprised to find that Ramsay's type of Phyllacanthus australis is a fine example of the Sea-urchin Mr. Agassiz and I have called Stephanocidaris bispinosa. It is not strange that no one has suspected it hitherto, for Ramsay gives virtually no description but relies on three photographs to make clear the specific characters. The whole nomenclatural tangle is now fairly well cleared up, and apparently all living students of the recent Echini are agreed as to the proper use of Lamarck's names for cidarids, even though we still disagree as to generic divisions.

The present series of $P$. australis ranges from 27 to $73 \mathrm{~mm}$. in test-diameter, horizontally (h.d.) ; the specimen with h.d.= $27 \mathrm{~mm}$., has primary spines $67 \mathrm{~mm}$. long or $2.5 \mathrm{~h} . \mathrm{d}$., while in the big individual they are only $60-65 \mathrm{~mm}$. long or less than h.d. Evidently $65-70 \mathrm{~mm}$. is the full length of the spine for this species, and growth ceases when that length is attained, though the test may continue to grow indefinitely. The primary spines when young are purple and smooth; they soon develop sharp teeth along the sides, and with this development the spine becomes somewhat flattened; at least the oral side is more or less flattened, the aboral side tending to become carinate; the spine is thus almost or quite triangular in cross-section, where widest; as the lateral teeth increase in size numerous similar but smaller teeth arise, particularly along the aboral side; with this change in form of the spine there goes an equally great change in colour ; the teeth are greenish and as they increase in number the spines appear to be less and less purple; as the spine matures it becomes coated with a loose, colourless or whitish calcareous coat which completely masks the remaining purple colour ; then Sponges, Bryozoa, Brachiopods, Lamellibranchs, Wormtubes and Barnacles (but particularly Barnacles) proceed to encrust the adult spines, making them the habitations of small Brittle-stars and Crustaceans. Many of the old, short actinal primaries (but not the small ones around the mouth) become very flaring at the tip in old individuals; thus a spine $3.3 \mathrm{~mm}$. in diameter near the middle may be almost $5 \mathrm{~mm}$. across the obliquely truncate and almost flat tip. The white spots on the collar of the primaries appear as soon as the collar is formed; they are always visible, but the distinctness 
differs much in different individuals and on different spines; occasionally they merge into more or less complete longitudinal lines, but this is unusual; they are often well developed on the neck of the spine above the collar. The actinal primaries have the collar very wide, and a thick, somewhat serrate "cap" formed from the outer layer of the spine.

The abactinal system is larger than the actinostome, but the difference shows some diversity; in the smallest specimen the actinostome is little more than $8 \mathrm{~mm}$., while the abactinal system is nearly 12 ; in the largest specimen the measurements are approximately 25 and 32 ; but in a specimen of average size the measurements are only 18 and 20 .

The secondary spines show remarkable diversity of colour; in several specimens they are bright red, with those of the ambulacra more or less greenish at both base and tip, and those of the interambulacra with very slightly greenish tips. In other cases they are reddish with purple tips and a longitudinal purplish stripe, or they are dull flesh-colour with red longitudinal stripe. In the largest specimens, all the secondaries are more or less greenish, those of the interambulacra with darker longitudinal stripe and pink or purplish tip, while those of ambulacra are more nearly uniformly dark greenish. Evidently no specific character can be drawn from the colouration of the secondary spines!

The occurrence of globiferous pedicellariæ shows an equal diversity ; in many specimens they are rare or wholly wanting, but in the larger specimens they are generally present, at least in the interambulacra, and in several of the biggest specimens they are excessively abundant and very conspicuous, as they are white or pale greenish in colour. The stalk is $3 \mathrm{~mm}$. long (more or less) and has a very conspicuous limb. The head is about a millimeter long and the valves seem to be like those of $P$. baculosa. I have hitherto laid much stress on the absence of globiferous pedicellarix in "Stephanocidaris bispinosa, A. Agassiz," but evidently the two specimens previously seen by me were misleading. I can no longer doubt that this species and baculosa are congeneric and that I have been wrong in counting the latter a Phyllacanthus. Since as already shown the name Stephanocidaris must be abandoned, I follow Döderlein in using Prionocidaris, of which $P$. pistillaris (=baculosa) is the type, for the group I have hitherto called Stephanocidaris, the diagnosis being modified to permit the inclusion of baculosa. Thirty-four specimens,

Locs.-Off Fraser Island, Queensland. 
Twenty-five miles south-east of Double Island Point, Queensland.

Eleven miles south-east of Ballina, New South Wales, 2729 fathoms.

Genus Cidaris, Leske.

Cidaris Conferta, ${ }^{1} s p$. nov.

(Plate xxxviii., fig. 1-4.)

Test little flattened; vertical diameter about $.60-.70$ of horizontal; coronal plates 7 or 8 ; areolæ large, nearly circular, only the lowest 2 or 3 confluent ; median interambulacral area with vertical suture quite distinct and 3-4 series of tubercles on each side of it; ambulacra about one-fourth of interambulacra in width; poriferous zones not sunken, very narrow, the pores close together; median ambulacral area with a double series of tubercles on each side, inner much smaller; vertical suture not very distinct ; pores large, nearly circular, only slightly oblique. Abactinal system about 46 of horizontal diameter of test, nearly circular and clearly defined, flat or slightly elevated, well covered with small secondary spines; genital plates large and nearly square, outer margin a little convex and inner equally or more concave, with pores near distal margin; ocular plates triangular or with inner angle truncated when plate is fully insert, as wide as high or wider, with pores very close to distal margin; in four specimens oculars $I, V$ and IV are insert, while in the largest specimen all are insert, though IV is very narrowly so ; anal system about one-half diameter of abactinal system, covered by a marginal series of 8-10 rather large plates and 12-15 (or more) smaller ones within ; all abactinal and anal plates are fairly covered by rather coarse tubercles; there are 2-10 on the anal plates, 30 or more on the oculars, and 50 or more on the genitals. Actinostome small, only about .37 of horizontal diameter of test, not at all sunken, closely covered by stout plates, 12-15 in each interambulacrum and about a dozen pairs in each ambulacrum. Primary spines when fully grown $60-70 \mathrm{~mm}$. long, and $2.5-3.5 \mathrm{~mm}$. thick, cylindrical and tapering rather abruptly to a bluntly pointed tip; in the largest specimen they are distincly compressed near tip; except when still immature, they are very closely covered by low, rounded granules, which are so closely crowded they do not form longitudinal series as is usual ; the collar is very low, about $1-1.5 \mathrm{~mm}$. high, very finely striate

1. Confertus = crowded; in reference to the densely crowded granules on the primary spines. 
longitudinally ; neck smooth, shining, porcelain-like ; as the spine gets older, the smooth, shining neck comes to occupy more and more of the spine, so that in old spines only the distal half or two-thirds shows the crowded granules clearly ; actinal primaries, smooth, flattened, not at all serrulate, with very broad collars; secondaries, narrow, flat and blunt. Pedicellariæ much as in Cidaris affinis, Phil.; large globiferous pedicellariæ very infrequent, wanting in some specimens ; tridentate pedicellariæ rather numerous; small globiferous somewhat less so. General colour of test yellowishbrown or dull reddish ; secondary spines whitish or yellowish, the larger ones about the primaries with a longitudinal stripe on the outer side, of brownish, greenish or yellowish tint; this stripe may be very faint and is often wanting, but is probably characteristic of the living animal ; secondaries often tipped with yellowish or reddish; primary spines pure white (more or less soiled and encrusted distally) with yellow-brown collar; in the smallest specimen many of the primaries are encircled by two narrow, widely separated, rather faint rings of dull rose-red. The smallest specimen is $25 \mathrm{~mm}$. in diameter, the largest $45 \mathrm{~mm}$; the latter is $33 \mathrm{~mm}$. high. Five specimens.

At first glance these specimens look very much like Cidaris cidaris of Europe or $C$. abyssicola of Florida, but on more careful examination the relationship to $C$. affinis becomes more evident. I am no longer willing to separate affinis from cidaris generically, for in large series of specimens it is difficult to separate them even specifically. I have therefore abandoned the genus Tretocidaris in the sense in which I formerly used it, and I am the more ready to do this because I think the "splitting" of genera has been already carried too far in the Cidaridæ, and we need now to do a little consolidating and redefining.

The occurrence of the present species off South-eastern Australia is very interesting, for no nearly related species has been taken by the "Challenger," "Siboga," "Valdivia " or "Albatross" in their various collections in the Indian and Pacific Oceans. The "Challenger" species, C. bracteata, recently found off Western Australia, is as near an ally as any, but the difference in the primary spines is very marked. Indeed, the crowded condition of the granules on the primaries of $C$. conferta, and the lack or faint indication of longitudinal series in their arrangement, readily distinguish the present species from any cidarid with which I have compared it.

Locs.-Eastern Slope, Bass Strait, 80-200 fathoms.

South of Gabo Island, Victoria, about 200 fathoms. 
Genus Goniocidaris, L. Agassiz and Desor.

Goniocidaris Clypeata, Döderlein.

Goniocidaris clypeata, Döderlein, Arch. f. Naturg., li. i., 1885 , p. 82.

It is only after much hesitation that I refer these little Echini to this Japanese species, but were they from Sagami Bay, Japan, I should do so without question. All are small, and only eight show the characteristic clypeate spines, but there is at least one of these from each of the stations listed below. All the specimens agree in a greenish colouration, or at least in having a greenish tinge, particularly on the actinal primaries and in lacking the big globiferous pedicellarix characteristic of the two following species. The largest specimen is $20 \mathrm{~mm}$. in horizontal diameter and comes from off Cape Pillar, Tasmania. I have compared it with a specimen of the same size from Japan, and while there are obvious differences, they are so trivial that I cannot find a single good character, nor any tangible combination of characters, which would justify calling the two specimens by different specific names. The "Siboga" took, in the East Indies, south of the equator, a cidarid which de Meijere called $G$. hirsutispinus but which I believe to be G. clypeata, so that the occurrence of this species in both Japanese and Tasmanian waters is not so improbable as at first appears. Fourteen specimens.

Locs._Off Port Davey, Tasmania, 88 fathoms.

Near Storm Bay, Tasmania.

North-east of Cape Pillar, Tasmania, 80 fathoms.

Twenty miles east of Maria Island, Tasmania, 128 fathoms.

Oyster Bay, Tasmania, 20-40 fathoms.

East of Babel Island, Bass Strait, 65-70 fathoms.

\section{GONIOCIDARIS GERANIOIDES (Lamarck).}

Cidarites geranioides, Lamarck, Anim. sans Vert., iii., 1816, p. 56.

Goniocidaris geranioides, Agassiz and Desor, Ann. Sci. Nat., Zool., (3), vi., 1846, p. 337.

These specimens are nearly all small, only four exceeding $25 \mathrm{~mm}$. in diameter. The largest, $37 \mathrm{~mm}$. in diameter, is a good example of the species and shows the distinguishing characters well. The two other adults ( 30 and $32 \mathrm{~mm}$.) are less typical, but are undoubtedly $G$. geranioides. Many of the 
smaller specimens approach $G$. tubaria and the very young are distinguishable only with some difficulty. The differences between the preceding species, $G$. clypeata, and young $G$. geranioides are also very slight, but they seem to be constant; in the Tasmanian specimens of $G$. clypeata there are no large globiferous pedicellariæ, while these are generally very common in $G$. geranioides, and the actinal primaries are more or less greenish, which is not the case in $G$. geranioides. The growth changes in $G$. geranioides, as revealed by the present series are very interesting. Young specimens have either long, slender and often perfectly smooth primaries (i.e., without thorns and prickles) or they are short, moderately stout and with a few coarse thorns. As the individual matures, the spines become more and more stout and the abactinal ones become expanded at the tip; they are rough, but not spiny, the coarse thorns which may have been present in youth, wearing down more or less markedly. Meanwhile the miliary tubercles and spines encroach more and more on the median ambulacral area, until the adult ladder-like arrangement of transverse ridges is perfected. As a result of these changes the mature specimens $(30 \mathrm{~mm}$. and over) look very unlike the young. Thirty-one specimens.

Locs.-Oyster Bay, Tasmania, 20-40 fathoms.

North-east of Cape Pillar, Tasmania, 80 fathoms.

Seven miles north-east of Cape Pillar, Tasmania, 50-60 fathoms.

Near Storm Bay, Tasmania.

Off Port Davey, Tasmania, 88 fathoms.

South-west of Rocky Point, Tasmania.

Near Mainwaring Cove, Tasmania, 50 fathoms.

Forty miles west of Kingston, South Australia, 30 fathoms.

Off Cape Marsden, Kangaroo Island, South Australia, 17 fathoms.

South of St. Francis Island, 35 fathoms.

\section{GONIOCIDARIS TUBARIA (Lamarck).}

Cidarites tubaria, Lamarck, Anim. sans Vert., iii., 1816, p. 57.

Goniocidaris tubaria, Lütken, Vid. Med., 1863 (1864), p. 137.

This is a very good series of this well-known and characteristic species. The eighty-eight specimens range in size from 10 to $50 \mathrm{~mm}$. (horizontal diameter). The primary spines seem to reach their maximum length, $40-50 \mathrm{~mm}$., 
when the individual is about half grown (test diameter, $25 \mathrm{~mm}$.), after which they may increase greatly in thickness, spininess and general bizarre appearance; they may decrease in length, probably from attrition, for the largest specimen in the present series has no primary $25 \mathrm{~mm}$. long. This specimen, by the way, comes from the same station (and bears the same registered number), as the largest and most typical example of $G$. geranioides; in colour it is somewhat like the latter, as well as in the character of the primary spines, but the test is that of a perfectly typical $G$. geranioides. I confess to being uncertain as to the true interrelationships of the Australasian species of Goniocidaris. It will be noticed that all the specimens of G. clypeata taken by the "Endeavour" are from southern and eastern Tasmania ; those of $G$. geranioides are from southern and western Tasmania and South Australia; while the range of G. tubaria is from northern New South Wales southward and westward to western South Australia, barely touching Tasmania. The specimen listed from Oyster Bay, Tasmania, is, however, a perfectly typical $G$. tubaria. Unfortunately we know very little of $G$. umbraculum from New Zealand, and only three old, bare tests are available for my study. After examination of the evidence I can secure, I am inclined to think that we shall ultimately consider G. tubaria and G. geranioides as one species (for which the latter name will be used) but separate subspecies, while the form here listed as $G$. clypeata will prove to be identical with $G$. umbraculum, which will in turn be considered a sub-species of $G$. geranioides. The Australasian forms of Goniocidaris would then list as follows :-

G. geranioides (Lamarck).-Southern Tasmania and westward to the Great Australian Bight.

G. g. tubaria (Lamarck).- - Southern coasts of continental Australia, from northern New South Wales to central Western Australia.

G. g. umbraculum (Hutton).-Eastern Tasmania and New Zealand. I think $G$. umbraculum is undoubtedly distinct from the Japanese $G$. clypeata, but am unable to give any satisfactory differences at present.

Locs.-Eleven miles south-east of Ballina, New South Wales, 27-29 fathoms.

Six miles east of Cape Hawke, New South Wales, 47-50 fathoms.

Shoalhaven Bight, New South Wales, 15-45 fathoms.

Eastern Slope, Bass Strait, 80-200 fathoms.

Twenty miles east of Babel Island, Bass Strait, 65 fathoms. 
Off Babel Island, Bass Strait, 50-60 fathoms.

Oyster Bay, Tasmania, 30 fathoms.

Twenty-four miles south-south-east of Eagles Nest Rock, Victoria, 15 fathoms.

Forty miles west of Kingston, South Australia, 30 fathoms.

Off Cape Marsden, Kangaroo Island, South Australia, 17 fathoms.

South of St. Francis Island, South Australia, 35 fathoms*

\section{Genus Histocidaris, Mortensen.}

Histocidaris elegans (A. Agassiz).

Porocidaris elegans, A. Agassiz, Proc. Amer. Acad., xiv., 1879 , p. 198.

Histocidaris elegans, Mortensen, "Ingolf" Ech., pt. 1, 1903 , p. 22.

This is an interesting quartette, each one having some point of special interest. The smallest is $20 \mathrm{~mm}$. in horizontal diameter (h.d.) and 12 in vertical (v.d.) ; there are only 6 coronal plates in each series; the primary spines are $50-58$ $\mathrm{mm}$. long, and while finely spiny have no coarse thorns; the test, secondaries and collar of the white primaries are dull, deep gray-purple. The next specimen is $38 \mathrm{~mm}$. h.d. and 25 v.d. ; there are 7 or 8 coronal plates; the primary spines are wonderfully fine, $100-130 \mathrm{~mm}$. long, $3 \mathrm{~mm}$. thick, and very thorny near base, becoming finely spiny near tip; the colour is like that of the small specimen. The third specimen is remarkable for the size and shape of the test and the number of coronal plates; h.d. $=71 \mathrm{~mm}$., and v.d. $=61$, so that the height is .85 of h.d. ; there are 12 coronal plates and excessive number for a recent cidarid; the primary spines are all broken or missing (except actinally), but it is evident that none were thorny; the test is deep yellow-brown, the secondaries, pedicellarix, etc., dirty whitish; the general condition of the specimen is poor though the test is perfectly whole. The fourth specimen is remarkable only because of its large size, h.d. $=78 \mathrm{~mm}$., and v.d. $=58 ; \mathrm{v} . \mathrm{d} .=.75$ h.d. ; there are 10 or 11 coronal plates; the primary spines are as a rule broken, but a number are whole, all are coarsely thorny and the longest probably exceeded $100 \mathrm{~mm}$. It would seem that in this species, as in the preceding species of Goniocidaris, the primary spines reach their full length, $100-130 \mathrm{~mm}$. when the test is about half grown, and that subsequent changes are 
relatively slight, except as accident or attrition may decrease the length.

With reference to the generic name of this species, I think Lambert and Thiéry are right in objecting to any recent species being assigned to the genus Porocidaris; it is very unlikely that any now known really belong there; certainly none show the distinctive generic feature. On the other hand I think it still worse to put these characteristic recent forms into Pomel's ill-defined and heterogenous group Plegiocidaris, as my esteemed French colleagues do, and I believe the best plan is to follow Mortensen in creating a special genus Histocidaris. I differ from him, however, in considering purpuratus as much a member of Histocidaris as is elegans, and hence I am obliged to reject his proposed genus Poriocidaris. Including purpuratus, Histocidaris is one of the most natural genera yet recognised in the family.

Locs.-Eastern Slope, Bass Strait, 80-200 fathoms.

East of Flinders Island, Bass Strait, 100-300 fathoms.

\section{Family CENTRECHINID $E$. \\ Genus Astropyga, Gray. \\ Astropyga radiata (Leske).}

Cidaris radiata, Leske, Add. ad Klein, 1778, p. 52.

Astropyga radiata, Gray, Ann. Phil., xxvi., 1825, p. 426.

The finding of this conspicuous Sea-urchin so far to the south of its previously known range is one of the "Endeavour's" many interesting discoveries. The "Siboga" took specimens near Ceram, north-west from New Guinea, but the genus has not hitherto been found in Torres Strait or anywhere on the Australian coast. The present specimens are 110 and 145 $\mathrm{mm}$. in diameter; the larger is dull dark red, the primaries, especially the actinal ones, with a greenish cast; the smaller is reddish-white with actinostome, genito-ocular ring and outer half (or more proximally) of each abactinal interambulacral plate, rose-red; the abactinal blue spots show up plainly on the smaller specimen, but are much less distinct on the larger and darker one. The actinal primaries of the smaller specimen are prettily, transversely banded. Two specimens.

Loc.-Twenty-five miles south-east of Double Island Point, Queensland, 33 fathoms. 
Genus Chatodiadema, Mortensen.

Chmtodiadema granulatum, Mortensen.

Chotodiadema granulatum, Mortensen, Vid. Med., 1903, p. 1.

This is another East Indian species, not previously known from south or east of Torres Strait, whose range the "Endeavour" has found to extend to southern Queensland. The "Challenger" took some small specimens west of Torres Strait, which were recorded as Astropyga pulvinata. The present specimen is larger than any hitherto recorded, measuring $115 \mathrm{~mm}$. h.d. Its colour is also different, the abactinal surface being brownish-olive and the primary spines pink; orally, test and spines are whitish, the primaries with a green tinge; the abactinal blue spots are conspicuous and are distributed as described by Mortensen.

Loc.-Twenty miles north-east of Double Island Point, Queensland, 29-30 fathoms.

\section{Family ECHINOTHURID $\approx$.}

Genus Aræosoma, Mortensen.

Areosoma thetidis (H. L. Clark).

Asthenosoma thetidis, H. L. Clark, Bull. Mus. Comp. Zool. Harvard, lii., 1909, p. 134.

Arceosoma thetidis, A. Agassiz and H. L. Clark, Mem. Mus. Comp. Zool. Harvard, xxxiv., 1909, p. 176.

These specimens are 115 - $180 \mathrm{~mm}$. h.d. and have the general appearance of those collected by the "Thetis." It is too bad that there is no knowledge of where most of these specimens were taken, for the range seems to be quite restricted. Apparently it is the only echinothurid in the shallower coastal waters of Australia.

Loc.-South of Gabo Island, Victoria, about 200 fathoms. Nine specimens.

Also eight specimens from an unknown locality.

Family ARBACIID $A$.

Genus Coklopleuros, L. Agassiz.

Coelopleurus australis, ${ }^{1} s p$. nov.

(Plate xliii., fig. 1.)

Test $40 \mathrm{~mm}$. h.d. and $24 \mathrm{~mm}$. v.d. ; height therefore is .60 h.d. Coronal plates 11 or 12 in a column, but only the

1. Australis = southern, in reference to its being the most southern representative of the genus. 
lowest 7 or 8 carry primary tubercles and spines ; interambulacral areas abactinally only about $8 \mathrm{~mm}$. broad. Ambulacral plates 12, each with a large primary tubercle; ambulacra $13 \mathrm{~mm}$. wide at ambitus, where interambulacra are about 11 , but only $8 \mathrm{~mm}$. abactinally where interambulacra are 8. Primary tubercles large and smooth, without crenulation or perforation, of course. Abactinal system about 11 $\mathrm{mm}$. across ; oculars all exsert ; anal system, $5.5 \mathrm{~mm}$. across, covered by 4 similar, triangular plates. Actinostome some $16 \mathrm{~mm}$. across, bare, except for the ring of buccal plates, close around the mouth which bear numerous, ophicephalus pedicellarix. Primary spines, when fully developed, $85 \mathrm{~mm}$. long, distinctly curved, tapering to a blunt point, which is nearly always broken off; collar about $11 \mathrm{~mm}$. long or about .13 of spine-length; it is very slightly further advanced on the dorsal keel of the spine than on the lower surface; on each side of the keel on the collar are two slight but distinct longitudinal ridges, and there are six such parallel ridges on the lower side of the collar; on most of the primaries above the ambitus the collar is much longer, $.30-.45$ of spine-length, or the uppermost spine or two is all "collar," i.e., has no smooth, polished surface. Actinal primaries very flat, thin, slightly curved, abruptly truncate, about half collar. Secondary spines, eylindrical or terete, stout and blunt, 4-5 $\mathrm{mm}$. long. Pedicellaria abundant; the valves of the ophicephalous are not at all constricted as in $C$. floridanus, but on the other hand are not so wide and blunt at tip as in $C$. longicollis. Colour of test much as in $C$. floridanus and $C$. longicollis, light brownish, or dirty cream-colour, with ocular plates, outer borders of genital plates, outer portion of abactinal interambulacral plates, and a narrow, zigzag, median ambulacral line, vermillion red; inner portion of abactinal interambulacral plates more or less lavender or rose-purple (according to dryness and conditions of lighting) ; secondary spines abactinally reddishbrown; uppermost primaries and collars of the others very light gray-brown with, often, a greenish tinge; in mature primaries the polished portion is light apple-green adjoining the collar, on upper surface, but very quickly passes into bright red (not abruptly, however); at the very tip of the spine may be one or two rather broad transverse bands of light green; lower surface of primaries, pure white; actinal primaries white, with collar pale grayish or gray-brown.

This is a very typical Coelopleurus and closely related to $C$. floridanus and $C$. longicollis, but it differs from both in the character of the dorsal interambulacra. The difference is marked when specimens are compared, but it is less easy to 
describe. Perhaps it may be most easily stated thus : in $C$. floridanus and $C$. longicollis, the genital plates are about the same width as the bare interambulacral space, while in $C$. australis they are about the same width as the entire interambulacrum. In $C$. austratis, the outer half of the upper interambulacral plates, which lack a primary tubercle, is well covered by a couple of secondary and 10-20 miliary tubercles ; in $C$. longicollis there are very few such tubercles on those plates; in $C$. floridanus, the tubercles are numerous, but are very small, so the surface of the outer end of the plate is granular, rather than tuberculous. The Australian species resembles $C$. longicollis in the large size of the dorsal ambulacral tubercles; they are even larger than in that species. It is also like $C$. longicollis in the characters of fully developed primary spines, but the collar is lower and the colouration is totally different. Coelopleurus has been taken at the Kei Islands and at New Britain, but its occurrence in Bass Strait extends the range of the genus over two thousand miles at least.

Loc.-Eastern Slope, Bass Strait, 60-112 fathoms.

\section{Family ECHINIDE.}

Genus Echinus, Linné.

Echinus Horridus, A. Agassiz.

(Plate xxxix.; Plate xl., fig. 1-2.)

Echinus horridus, A. Agassiz, Proc. Amer. Acad., xiv., 1879, p. 203.

The specimen from south of Gabo Island, Victoria, is not only the most remarkable Echinoid in the collection, but is one of the most extraordinary Sea-urchins which has ever been taken. It has a horizontal diameter at ambitus of $80 \mathrm{~mm}$. and a vertical height of $115 \mathrm{~mm}$.; there are 33 or 34 coronal plates and 61-62 ambulacrals, in each column ; the abactinal system is $12 \mathrm{~mm}$. across (.15 h.d.) and all the ocular plates plates are exsert; the anal system is nearly $5 \mathrm{~mm}$. across, and is covered by about 160 small plates, many quite granulelike, among which the flat, circular suranal is very prominent; the spines are nearly all missing; those which remain are small secondaries or the bases of broken, bright red primaries ; the actinostome is very small, only $11 \mathrm{~mm}$. across, or less than .15 h.d. I have compared this specimen with the fragments of a slightly larger specimen of $E$. horridus from off southern 
Chili, a cotype of Mr. Agassiz's species. The only difference. of importance is in the covering of the anal system, which in the Chilian specimen consists of fewer and larger plates. This may prove to be a good specific character, but only more abundant material can determine the point, and meanwhile the Australian specimen may best be considered as $E$. horridus, the resemblance in colour, shape and character of the test and spines being so very marked.

The specimen from east of Flinders Island, Bass Strait, is very much smaller, and is of great interest as indicating that the extraordinary increase in length of the vertical axis occurs only after the individual is half grown. The horizontal diameter of this specimen is $41 \mathrm{~mm}$. while the vertical is 32 ; v.d. is thus a little more than three-fourths h.d. ; the abactinal system $(8 \mathrm{~mm}$.) and actinostome $(7.5 \mathrm{~mm}$.) are relatively a little larger than in the adult, but are notably small. There are 23 coronal plates, indicating that while the height of the test is increasing over 250 per cent., the number of coronal plates increases less than 50 per cent. ; obviously the increase in height is due to marked increase in size of the coronal plates rather than to great increase in number. The colour of this smaller specimen is like that of the adult, reddish with bright red primary spines.

The specimen from off Maria Island, Tasmania, is obviously young. It is partly broken, and lacks the abactinal system entirely. It is $17 \mathrm{~mm}$. in diameter, with an actinostome $7 \mathrm{~mm}$. across and has 15-16 coronal plates in each column. There are no spines left. The tuberculation of the distinctly reddish test is much coarser relatively, if not actually than in the older specimens; in particular there are several secondary tubercles on each interambulacral plate which are very nearly equal to the primary tubercle in size. It is possible that this specimen is not a young $E$. horridus, but when locality and depth are considered it seems highly probable that it is. The developmental stages of this species would certainly be of extraordinary interest, and it is to be hoped that at some future day an oceanographic survey of the region between Tasmania and New Zealand and between the latter country and Chili may bring to light the necessary material. Three specimens.

Locs.-South of Gabo Island, Victoria, 100-250 fathoms.

East of Flinders Island, Bass Strait, 100-300 fathoms.

East-north-east of Maria Island, Tasmania, 125-180. fathoms. 
Genus Parechinus, Mortensen.

Parechindos notius, ${ }^{1} s p$. nov.

$$
\text { (Plate xli., fig. 1-3.) }
$$

Test $28 \mathrm{~mm}$. h.d. and 18 v.d. ; height, therefore, is .64 h.d. Coronal plates thick, rough, though not actually sculptured, 20 in a column, each with a primary tubercle whose areola is about half the height of the plate (in midzone) and on each side of which are two secondary tubercles, not much smaller than primary; the 5 tubercles form a horizontal series; above midzone on a few plates the secondary tubercles are somewhat more numerous and less regularly arranged, but the uppermost 4 or 5 plates have only $3,2,1$ or 0 ; interambulacra about $12 \mathrm{~mm}$. broad at ambitus. Ambulacral plates 22, but little lower than the interambulacral, each (in midzone) with a primary and 1 large secondary tubercle; the latter is near the inner end of the plate and disappears abactinally; ambulacra $7 \mathrm{~mm}$. wide at ambitus; poriferous zones narrow (1 $\mathrm{mm}$. wide), the arcs of pores vertical. Abactinal system small and compact, $7.5 \mathrm{~mm}$. across; all oculars exsert but I nearly in ; anal system large (4 mm. across) nearly circular, covered by numerous (about 30) plates, among which the nearly circular suranal is very distinct and much the largest; each genital plate carries 3 or 4 secondary tubercles, each ocular, 1. Actinostome rather large, $11 \mathrm{~mm}$. across; gill slits very slightly indicated; buccal membrane thin and perfectly bare, except for the 5 pairs of primordial ambulacral plates, which are very near the mouth, but do not form a closed ring; they are densely covered with ophicephalous pedicellariæ. Primary spines $7-8 \mathrm{~mm}$. long, abruptly and not sharply pointed, each with about 10 longitudinal ridges, low, rounded and close together; secondary spines similar but not so long and often somewhat swollen at tip; miliary spines very few, most of the relatively few miliary tubercles bearing pedicellariæ. Globiferous pedicellariæ fairly common, very similar to those found on the New Zealand form (albocinctus) of $P$. magellanicus; the blade is narrow, slightly widened near tip, with a long and conspicuous endtooth and a smaller and more slender tooth on the left side, below tip ; base of valve wider than in Mortensen's figure of $P$. albocinctus; tridentate pedicellariæ very rare or wanting, for I failed to find one; ophicephalous pedicellariæe very abundant; the valves are broadly rounded at tip and not at all constricted. Colour of test, very pale brown; spines white.

1. ขótıs=southern; in reference to its geographical position. 
I have been much puzzled by this Sea-urchin. It does not look like any of the many specimens of $P$. magellanicus which I have examined, but I am sure it is very nearly related to that species. Indeed it is difficult to point out any important distinguishing features. Perhaps the two most tangible differences are the narrow poriferous areas, with vertical ares of pores, in $P$. notius and the noticeable scarcity of miliary tubercles; in $P$. magellanicus miliary tubercles are abundant and the poriferous areas are moderately wide with the arcs of pores more or less oblique. The anal system of $P$. notius looks quite different from that of $P$. magellanicus, as it is nearly circular and is covered by much more numerous plates. The presence of only one lateral tooth on the globiferous pedicellariæ, instead of one on each side as in $P$. magellanicus, and the white primary spines of $P$. notius are also worthy of mention, though perhaps not reliable specific characters. It may also be mentioned, though I do not lay any weight on the fact, that in $P$. magellanicus the buccal plates bear numerous tridentate pedicellariæ, while in $P$. notius these plates are covered with ophicephalous. The fact that all oculars are exsert in $P$. notius is interesting and may ultimately prove to be a good specific character. The general appearance of abactinal system, spines, pedicellariæ and buccal membrane is very much that of an Amblypneustes, but the test is very different, as are the buccal plates. It is a pity the "Endeavour" did not secure an abundance of specimens of Parechinus, for the Australasian species of the genus sorely need elucidation and this single specimen only adds to the difficulties !

Loc.-South of Gabo Island to south-east of Cape Everard, Victoria, 70-80 fathoms.

\section{Genus Gyanechinus, Mortensen.}

GyMneChinus EPISTICHUS, H. L. Clark.

Gymnechinus epistichus, H. L. Clark, Mem. Mus. Comp. Zool. Harvard, xxxiv., 1912, p. 289.

This specimen resembles the holotype closely, but differs in two points; genital 3 (as not infrequently happens in this genus) is completely shut out from the periproct, and the primary spines, especially the actinal ones, are a decidedly more distinct red. The horizontal diameter of the test is $22 \mathrm{~mm}$.

Loc.-Twenty-five miles south-east of Double Island Point, Queensland. 
SEA LILIES, STARFISHES, ETC.-ULARK.

\section{Family TEMNOPLEURID}

Genus Salmacis, L. Agassiz.

SALMACIS OLIGOPORA, ${ }^{1} s p$. nov.

(Plate xlii., fig. 1-2; Plate xliii., fig. 2.)

T'est 60-81 mm. h.d. ; 29-39 mm. v.d. ; height therefore just less than half the horizontal diameter. Very similar to $S$. dussumieri and $S$. erythracis, but differing in at least three particulars; relative number of ambulacral and interambulacral plates in each column, form of base of valves of globiferous pedicellariæ, and colouration. The number of coronal plates in the specimens at hand runs from 28 to 34 , while the number of ambulacral plates in a column is from 43 to 55 ; thus the number of ambulacral plates is only .52-.62 more than the number of coronal plates; in S. dussumieri and $S$. erythracis it is .70-.87 more. The base of the valves of the globiferous pedicellariæe is rather higher than wide and the upper lateral corners are elongated to a much greater degree than in any other species of Salmacis, and flare outwards slightly. Finally the colouration is utterly unlike that of S. dussumieri and quite different from that of $S$. erythracis. The test is pale brownish; the miliary spines and pedicellaria are white, the secondary spines are white or pale greenish or tipped with greenish, and the primaries are greenish-white with 1-3 broad, indefinite bands of olive-green; the actinal primaries may be white without any green or they may be broadly tipped with olive-green; sometimes there is also a band of olive green near middle of spine. There is no hint of red or violet anywhere.

There are too few specimens of $S$. dussumieri and $S$. erythracis at hand to enable me to determine satisfactorily the relationship of the three species to each other. They agree in the peculiar characters of the ambulacra and abactinal system and so form a well marked section of the genus, but it is possible that the characters by which I have separated the three forms from each other are of less significance than I suppose.

One of the specimens of $S$. oligopora from off Sandon Bluffs, New South Wales, has a remarkably deformed abactinal area; the anal and genital plates are sunk much below the abactinal part of the ambulacra, and the latter are bent abruptly downwards and inwards to them; thus the vertical diameter of the test at the distal portion of genital I is $39 \mathrm{~mm}$.,

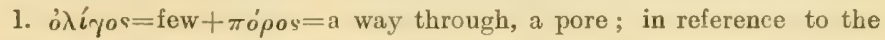
relatively small number of ambulacral pores. 
while at the third plate of ambulacrum IV it is $46 \mathrm{~mm}$; the sixth or seventh ambulacral plate is about on a level with the genital pores. Another specimen is remarkable in that four genitals are developed as madreporites; to judge from the position of the anus they are genitals $1,2,4$ and 5 ; each genital plate except 2 has two genital pores, so there are nine such pores altogether. In neither of these exceptional specimens is there any ocular insert. The same is true of the largest normal specimen, but there are 6 specimens in which ocular I is more or less broadly insert. Eight specimens.

Locs.-Oyster Bay, Tasmania, 20-40 fathoms. This specimen has been selected as the holotype.

Six miles east of Cape Hawke, New South Wales, 47-50 fathoms.

Eight miles east of Sandon Bluffs, New South Wales, 35-40 fathoms.

\section{SaLMaCIS SPH frRoIdeS (Linné).}

Echinus sphæroides, Linné, Sys. Nat., 10th ed., 1758, p. 664.

Salmacis sphoroides, Lovén, Ech. Linn., 1887, p. 69.

These specimens range in diameter from 40 to $80 \mathrm{~mm}$; the height ranges from .65 to .75 h.d. The colouration is exceptionally red, the actinal primaries in particular being bright, almost vermilion, red with several bands of white; abactinally, however, the primaries, even in the reddest specimen, are green or greenish at base. Seven specimens.

Loc.-Twenty miles north-north-east of Double Island Point, Queensland, 29-30 fathoms.

\section{Salmacis virgulata (L. Agassiz and Desor).}

Salmacis virgulata, L. Agassiz and Desor, Ann. Sci. Nat., Zool., vi., 1846, p. 359.

The specimens without definite locality are large, typical examples of this species, showing little or no trace of the horizontal sutural furrows of $S$. alexandri: they measure 75 and $90 \mathrm{~mm}$. h.d. respectively. The specimen from off Double Island Point, Queensland, is much smaller (only 48 mm. h.d.) and has the sutural furrows well marked; its most striking feature, however, is the colouration of the primary spines, which at first glance seem to be whitish with 
a broad indistinct band of purple around the middle; the specimen is in poor condition, however, and I think the colour of the spines has been altered; I believe they were, as usual, greenish at base, violet or purple distally and with an indistinct light tip; in the process of preservation the green tint has been nearly completely obliterated.

The occurrence of typical $S$. virgulata on the coast of southern Queensland necessitates the acceptance of Döderlein's view that $S$. alexandri is at best only a subspecies of $S$. virgulata, and I am the more ready to do this because the Museum of Comparative Zoölogy has now a typical specimen of S. alexandri from Badu Island, Torres Strait. Obviously the geographical ranges of the two forms are by no means distinct. Three specimens.

Locs.-Off the coast of Queensland.

Twenty-five miles south-east of Double Island Point, Queensland.

\section{Genus Mrcrocyphus, L. Agassiz and Desor.}

Microcyphus annulatus, Mortensen.

Microcyphus annulatus, Mortensen, Siam Ech., 1904, p. 101. This is a typical example of this species, $11 \mathrm{~mm}$. in diameter.

Loc.-Seven miles north-east of Cape Pillar, Tasmania, 50-60 fathoms.

Genus Amblypnedstes, L. Agassiz.

Amblypneustes grandis, H. L. Clark.

Amblypneustes grandis, H. L. Clark, Mem. Mus. Comp. Zool. Harvard, xxxiv., 1912, p. 329.

These are all large specimens, $50-63 \mathrm{~mm}$. in diameter, with the height ranging from .60 to .76 h.d. In colouration there is considerable diversity. The specimens from an unknown locality are light brown, with the small spines whitish and the primaries greenish-brown, tipped with whitish; in one specimen the greenish-brown is confined to the basal part of the spine, especially on the actinal surface. The specimens from Flinders Island, Bass Strait, are similar but more green; the test is olive-greenish and the basal part of the primaries is more green than brown; in one specimen the primaries are nearly all white. The specimen from between Gabo Island, Victoria, and Disaster Bay, New South Wales, 
is similar to the latter specimen, the primaries being almost wholly white, though the test is distinctly greenish. The South Australian specimen is the most peculiar, for while the test is greenish and not very unusual, the primary spines are all pale reddish with light tips; actinally the light shade occupies more of the spine than the reddish tint. All the specimens show a zigzag band (similar to that of $A$. formosus) in the abactinal interambulacra, indistinct when the test is dry but very evident when the surface is moistened; the markings differ obviously from those of $A$. formosus, however, by being darker than the intervening angles.

Döderlein ${ }^{1}$ has recently reviewed anew the species of Amblypneustes, adding another species and a variety to the already perplexing list. He is inclined to doubt the validity of both the present species and the next, considering them forms of $A$. grisens, but I am unable to agree with him. I confess, however, that I do not believe we have yet reached the truth in regard to the species of this interesting genus. We really have not as yet any clear idea as to the limits of variation in either form, tuberculation or colour, in even a single species, and we zoologists who are thousands of miles from the restricted home of the genus, are thus working largely in the dark in our efforts to identify specimens. Some day a zoologist on the ground, or with a careful and enthusiastic collector on the ground, will secure sufficient material to enable him to work out the actual natural limits of each species. Seven specimens.

Locs._-East coast of Flinders Island, Bass Strait.

Between Gabo Island, Victoria, and Disaster Bay, New South Wales, 50-100 fathoms.

Off Cape Marsden, Kangaroo Island, South Australia, 17 fathoms.

Also two specimens from an unknown locality.

\section{Ambly pneustes pachistus, H. L. Clark.}

Amblypneustes pachistus, H. L. Clark, Mem. Mus. Comp. Zool. Harvard, xxxiv., 1912, p. 327.

These individuals range in size from 31 to $45 \mathrm{~mm}$. h. d.; the height ranges from a little over .80 h.d. in the smallest to a little less than .90 h.d. in the largest. The colour is the same in all: test, pale brown when dry, more nearly olive

1. Döderlein-Fauna Südwest-Australiens, iv., 1914, pp. 460-475. 
when moist; small spines, pale cream-colour or whitish; large spines, deep olive-green or greenish-brown, more or less extensively tipped with whitish. This is essentially the colouration of the holotype and is apparently the characteristic colouration of the species, which seems to me a perfectly valid one. Four specimens.

Locs.-Oyster Bay, Tasmania.

East coast of Flinders Island, Bass Strait.

Forty miles west of Kingston, South Australia, 30 fathoms.

Genus Holopneustes, L. Agassiz and Desor.

Holopneustes inflatus, $A$. Agassiz.

Holopneustes inflatus, A. Agassiz, Bull. Mus. Comp. Zool. Harvard, iii., 1872, p. 56.

The smallest individual is $30 \mathrm{~mm}$. h.d. and $23 \mathrm{~mm}$. high, while the largest is $72 \mathrm{~mm}$. h.d. and $65 \mathrm{~mm}$. high. All three specimens are light coloured, the spines both large and small being pale gray or nearly eream-colour. The test is decidedly darker, at least when wet. It is interesting to note that in this species, as in the preceding and in Echinus horridus, the relative height increases with age; in the present case the increase is from .77 h.d. to a trifle over .90. Four specimens.

Locs.-North-east of Cape Pillar, Tasmania, 80 fathoms.

Oyster Bay, Tasmania.

East coast of Flinders Island, Bass Strait.

Holopneustes porosissimus, L. Agassiz and Desor.

Holopneustes porosissimus, Agassiz and Desor, Ann. Sci. Nat., Zool., vi., 1846, p. 364.

This individual is $40 \mathrm{~mm}$. in diameter and $38 \mathrm{~mm}$. high ; the height is thus .95 h.d. The ambulacra are $13 \mathrm{~mm}$. wide and the interambulacra $11.5 \mathrm{~mm}$. The test is dull purple and the spines are dull purplish-red, without any green (as is usual) near the base.

Loc.-Off Cape Marsden, Kangaroo Island, South Australia. 
Family STRONGYLOCENTROTID $\mathrm{E}$.

Genus Heliocidaris, L. Agassiz and Desor.

Heliocidaris erythrogramia (Valencienes).

Echinus erythrogrammus, Valenciennes, Voy. Venus, Zooph.. 1846, pl. vii., fig. 1.

Heliocidaris eurythrogramma, Agassiz and Desor, Ann. Sci. Nat., Zool., vi., 1846, p. 371.

The specimens from Oyster Bay, Tasmania, are typical examples of the species, about $50 \mathrm{~mm}$. in diameter, dark purplish in colour, becoming dull green with a purplish cast when dry. The specimen from Flinders Island, Bass Strait, is $68 \mathrm{~mm}$. in diameter, with the test very pale brownish and the spines light olive green, as in $H$. tuberculata. The shortness of the primaries and the absence of any arcs of pores. with more than 7 pairs show it must be referred to $H$. erythrogramma. I do not feel satisfied, however, that there are really four species of Heliocidaris on the southern and western coasts of Australia, as Döderlein affirms in his recent revision of the genus, ${ }^{1}$ but I think it quite possible that these four forms will prove to be either a single species or perhaps. two. I may here protest against Döderlein's action in putting the Peruvian Echinoid, Coenocentrotus gibbosus, into Heliocidaris. The differences in ambulacra, abactinal system, coronal plates and spines far outweigh the single resemblance in globiferous pedicellariæ. If the latter is such a weighty character, the species ought to be put in the family Temnopleuridæ, for the globiferous pedicellariæ are surprisingly similar to those of Salmacis and Temnopleurus! On the other hand, I think Döderlein is right in refusing to include the Japanese species crassispina in Heliocidaris. It is better left in Strongylocentrotus, if one is unwilling to recognise the genus Anthocidaris for its reception. Four specimens.

Locs.-Oyster Bay, Tasmania, 30 fathoms.

East coast of Flinders Island, Bass Strait.

\section{Family CLYPEASTRID E.}

Genus Clypeaster, Lamarck.

Clypeaster australasiæe (Gray).

Echinanthus australasice, Gray, Proc. Zool. Soc., 1851, p. 34.

Clypeaster australasioe, H. L. Clark, Mem. Mus. Comp. Zool. Harvard, xlvi., 1914, p. 32.

The smallest of these individuals is $46 \mathrm{~mm}$. long, $42 \mathrm{~mm}$. wide and $14 \mathrm{~mm}$. high ; the largest is $90 \times 80 \times 30 \mathrm{~mm}$. The

1. Döderlein-Fauna Südwest-Australiens, iv., 1914, pp. 475-487. 
widest specimen is .91 as wide as long; the narrowest is .82 . In the highest specimen the vertical diameter is .41 of the length; in the flattest it is .29. The colour is some shade of brown, usually with a greenish tinge. Several of the specimens are slightly asymmetrical in one way or another. Ten specimens.

Locs.-Six miles east of Cape Hawke, New South Wales, 47-50 fathoms.

Shoalhaven Bight, New South Wales, 15-45 fathoms.

East of Babel Island, Bass Strait, 65-70 fathoms.

\section{Clypeaster telurus, H. L. Clark.}

Clypeaster telurus, H. L. Clark, Rec. West Austr. Mus., i., 1914, p. 166.

The unique holotype of this species was taken on the coast of Western Australia almost directly across the Australian continent from Fraser Island, Queensland, but a prolonged critical study of these Clypeasters fails to show any character or combination which will distinguish them from it, except that they do not have the posterior interradial margin depressed appreciably. They are all larger than the holotype, the largest measuring $145 \times 135 \times 20 \mathrm{~mm}$. ; as a species character, it seems to be true that the breadth exceeds .90 of the length, while the height is less than .15. There are about 400 primary tubercles to a square centimeter of the aboral surface. The unpaired anterior petal is $39 \mathrm{~mm}$. long and has 52 pore-pairs. The periproct is $8-12 \mathrm{~mm}$. from the posterior margin, and this considerable distance, taken in connection with the thin, almost fragile, test, and the form of the petals, makes it easy to distinguish this species from C. humilis, which is its nearest relative. Tridentate pedicellariæ, with valves $.25-.75 \mathrm{~mm}$. long, are common on the oral surface. The colour of these specimens is more or less. purplish-brown.

Loc-Off Fraser Island, Queensland. Four specimens.

Clypeaster virescens, Döderlein.

Clypeaster virescens, Döderlein, Arch. f. Naturg., li.i., 1885, p. 102.

This individual is $105 \mathrm{~mm}$. long, $95 \mathrm{~mm}$. wide and $19 \mathrm{~mm}$. high. The colour is yellow-brown with a distinct greenish tinge orally. Although none of the Japanese specimens at 
hand are quite so large, comparison with them fails to reveal a single character by which this specimen can be distinguished from them. It is hard to believe that a Japanese species, not yet known from the East Indies or northern Australia, should occur in Shoalhaven Bight, New South Wales, but this specimen seems to prove it. There is no chance for a misplaced label, for in this case the metal number is not only wired on to the test, but the wire is firmly rusted in! I have tried to convince myself that the specimen is an aberrant example of $C$. australasioe, but if that is the case the characters by which species in the genus are at present separated, are simply worthless, and we might as well call all Australian and all Japanese Clypeasters by a single name! I have also tried to find at least one character which would serve to distinguish this Australian specimen from the Japanese species, but I have not succeeded, and I am therefore obliged to record it as $C$. virescens.

Loc. - Shoalhaven Bight, New South Wales, 15-45 fathoms.

\section{Family LAGANDA. \\ Genus Peronella, Gray. \\ Peronella lesueuri (Agassiz).}

Laganum lesueuri, Agassiz, Mon. Scut., 1841, p. 116.

Peronella lesueuri, A. Agassiz, Rev. Ech., pt. 1, 1872, p. 148.

These are notably large individuals, and it is a pity that there is no record of either the locality or the depth. The largest one is $137 \mathrm{~mm}$. long, $124 \mathrm{~mm}$. wide, and only $12 \mathrm{~mm}$. high; the petaloid area is nearly .60 of test length, but the marginal thickness of the test is less than .03 of the length! The smallest specimen is $100 \mathrm{~mm}$. long. There is little diversity in shape; the narrowest specimen has the width .86 of the length, while in the widest it is .96 .

Loc.-Off the coast of Queensland. Nineteen specimens.

Family FIBULARIIDA.

Genus Echinocyamus, Leske.

Echinocyamus platytatus, H. L. Clark.

Echinocyamus platytatus, H. L. Clark, Mem. Mus. Comp. Zool. Harvard, xlvi., 1914, p. 63.

There is no doubt of the genus of these small pieces, but the reference to $E$. platytatus involves more uncertainty. I think it safe, however, to consider them that Victorian speries.

Loc.-Between Devonport and Launceston, Tasmania. 


\title{
Family SPATANGIDA.
}

\author{
Genus Maretia, Gray.
}

MaRetia Peloria, ${ }^{1} s p$. nov.

(Plate xliv., fig. 1-3.)

Length of test, $76 \mathrm{~mm}$. ; breadth, $65 \mathrm{~mm}$. ; height, $18 \mathrm{~mm}$. ; abactinal system $33 \mathrm{~mm}$. from anterior margin; mouth, 12 $\mathrm{mm}$. wide by $4 \mathrm{~mm}$. long, with a very prominent lip, its anterior margin $20 \mathrm{~mm}$. from test margin ; periproct, $9 \mathrm{~mm}$. in diameter, on the vertical posterior end of test; subanal fasciole, distinct but narrow, its area $24 \mathrm{~mm}$. wide by $4 \mathrm{~mm}$. high at middle; bare sternal area nearly $30 \mathrm{~mm}$. wide posteriorly. Unpaired petal indistinct, virtually wanting. Anterior petals very imperfect, but the posterior series of porepairs can be distinguished for about $25 \mathrm{~mm}$. from apex. Posterior petals fairly well developed, about $35 \mathrm{~mm}$. long and $7 \mathrm{~mm}$. wide just proximal to the very slightly narrowed tip; there are rather more than 20 pore-pairs on each side of the petal. Anterior ambulacrum, although not petaloid, is plainly indicated as a gradually widening area, covered only by miliary spines (or tubercles) ; proximally it is very narrow ; on each side is a series of 12-15 simple tube-feet (or pores), at first close together but near margin 3-4 mm. apart. Genital pores 4, large, but close together and concealed by the dense growth of miliary spines which covers the whole abactinal system and adjoining plates. Remainder of abactinal surface covered closely by more or less curved, slender miliary and secondary spines, pedicellariæ and scattered primaries; the latter are nearly all broken, but when complete are $15-20 \mathrm{~mm}$. long and taper to a very slender tip; proximally they are hollow ; they are more or less distinctly curved near the base. In each antero-lateral interambulacrum there are about 35 primaries above the ambitus; each is attached to a large, perforated tubercle placed in a deeply sunken areola ; in each postero-lateral interambulacrum there are some 50 similar primaries, and in the posterior interambulacrum there are about 25, but these latter are as a rule smaller than the primaries of the lateral areas.

Actinal surface largely free from spines and tubercles of any considerable size, except laterally and near anterior

1. $\pi \epsilon \lambda \dot{\omega} p \iota s=$ huge, immense; in reference to the size, remarkably large for a Maretia. 
margin. In the antero-lateral interambulacra the margin is densely clothed with secondary spines and 15-20 rather small primaries; there are also a few secondaries close to the mouth. In the lateral (or postero-lateral) areas the margin is densely coated with secondary and miliary spines and inwardly with 7 or 8 oblique series of large primaries, 4-5 in each series. Within the subanal fasciole there is on each side a group of $10-12$ primary spines, and below it is a triangular area (with apex towards mouth) well covered with secondary and miliary spines. All the rest of the oral surface seems bare, but is in reality sparsely covered with minute miliary spines and pedicellarix. The lip, however, bears a dense cluster of secondary spines, and there are smaller and less dense clusters on each side of the mouth, while similar spines are borne on the peristomal plates themselves. Phyllodes conspicuous, though in each one of the posterior pair there are only 7 of the ambulacral "brushes." Peristome covered by about 50 plates. Periproct covered by about 60 plates, each with 1-4 miliary spines.

Pedicellariæ abundant, of 4 kinds, each of which has 3 valves to make up the head; the valves of the globiferous pedicellariæ are about $1 \mathrm{~mm}$. long, the terminal third or more encased in the glandular tissue; these valves resemble those of Lovenia elongata as figured by Koehler ${ }^{1}$, but the blade narrows steadily to the truncate tip which terminates in 4 rather short but distinct teeth, lying practically in the same plane; the valves of the tridentate pedicellariæ are about $.80 \mathrm{~mm}$. long and resemble those of Spatangus; they are strongly curved, meeting only at tip ; the base is higher than wide, the blade is less than half the length, and its own width (which is greatest distal to its middle) is less than half its own length; its margin is smooth, becoming finely serrate near tip; the valves of the ophicephalous pedicellariæ are only about $.40 \mathrm{~mm}$. long; they resemble very closely those of Maretia elevata as figured by Döderlein²; the valves of the triphyllous pedicellariæ are very small, about $.20 \mathrm{~mm}$. long, and are borne on the end of a very long neck; they resemble very closely those of Metalia maculosa as figured by $K_{0 e h l e r}{ }^{3}$. The triphyllous pedicellariæ seem to occur everywhere on the test, the ophicephalous are mainly if not altogether abactinal, the tridentate occur on both the upper and lower surfaces, but seem more abundant actinally, and the globiferous are actinal, occurring chiefly near the mouth.

1. Koohler-Indian Mus. Spat., 1914, pl. xix., fig. 27.

2. Döderlein-Valdivia Ech., 1906, pl, xlviii., fig. 6a-d.

3. Koehler-Indian Mus. Spat., 1914, pl. xix., fig. 70. 
Colour, in alcohol or dry, pale purplish gray, the muscles around the bases of the primary spines, deep brown; small spines nearly white when dry; primary spines more or less pale purple or light gray; ambulacral "brushes" around mouth, nearly black.

Although resembling Maretia ovata (Leske) (=planulata, auct.) in form of test and in its generic characters, this species is easily distinguished by the longer and narrower posterior petals, the less complete anterior petals and the greater number of abactinal primary tubercles, particularly on posterior half of test. The primary spines are somewhat shorter, and those of the actinal surface are scarcely half as. numerous as in $M$. ovata. The pedicellariæ also offer some striking differences between the two species. The occurrence of the genus in Bass Strait is very interesting, for it is. essentially a shallow water, tropical group, and has been reported previously from only as far south as Port Jackson, New South Wales. While no depth is recorded for the station where $M$. peloria was taken, there is good reason for believing it was in the neighbourhood of 100 fathoms, for there is a station recorded "twenty-five miles south-west of Cape Everard, Victoria, 83-98 fathoms." In the Dutch East Indies, $M$. ovata was taken by the "Siboga" at one station in 83 fathoms, but as a rule $M$. ovata occurs from low water mark to about 20 fathoms. The largest specimen of $M$. ovata I have found recorded is $65 \mathrm{~mm}$. long, but this is unusual, and most specimens are from 30 to $50 \mathrm{~mm}$.

Loc.-Twenty-six miles south-west of Cape Everard, Victoria. Three specimens. 


EXPLANATION OF PLATE I.

Metacrinus cyaneus, sp. nov. Photograph of the holotype from the Eastern Slope, Bass Strait, about 200 fathoms. Three-fourths natural size. 


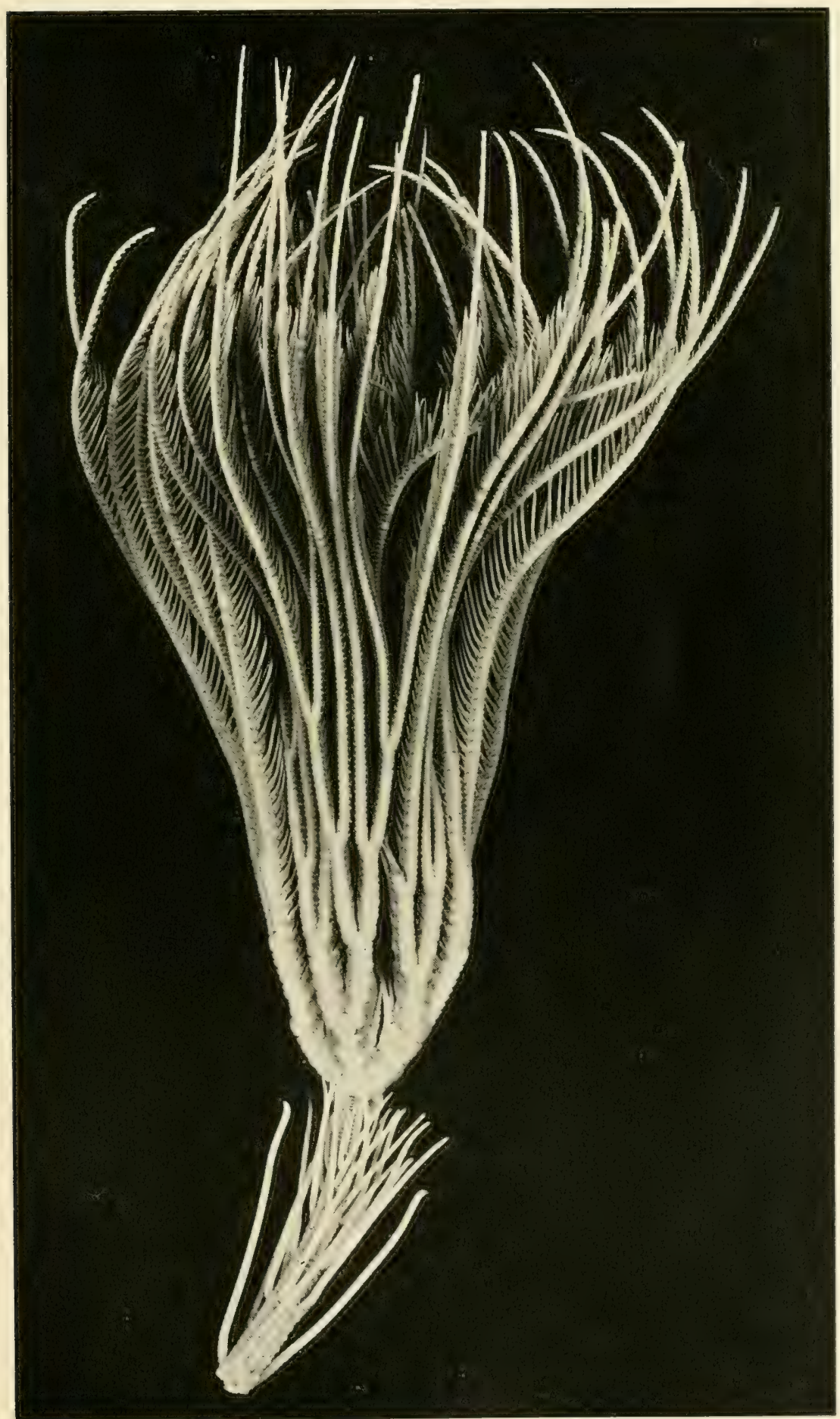

G. NeLson. Cambridge, U.S.A., photo. 




\section{EXPLANATION OF PLATE II.}

Fig. 1.-Comatula cratera, sp. nov. Photograph of the holotype from eight miles east of Sandon Bluffs, New South Wales, 35-40 fathoms. Six-sevenths natural size.

Fig. 2.-Oligometra zebra, sp. nov. Photograph of the holotype from eleven miles east-south-east of Clarence River mouth, New South Wales, 35-36 fathoms. Natural size. 

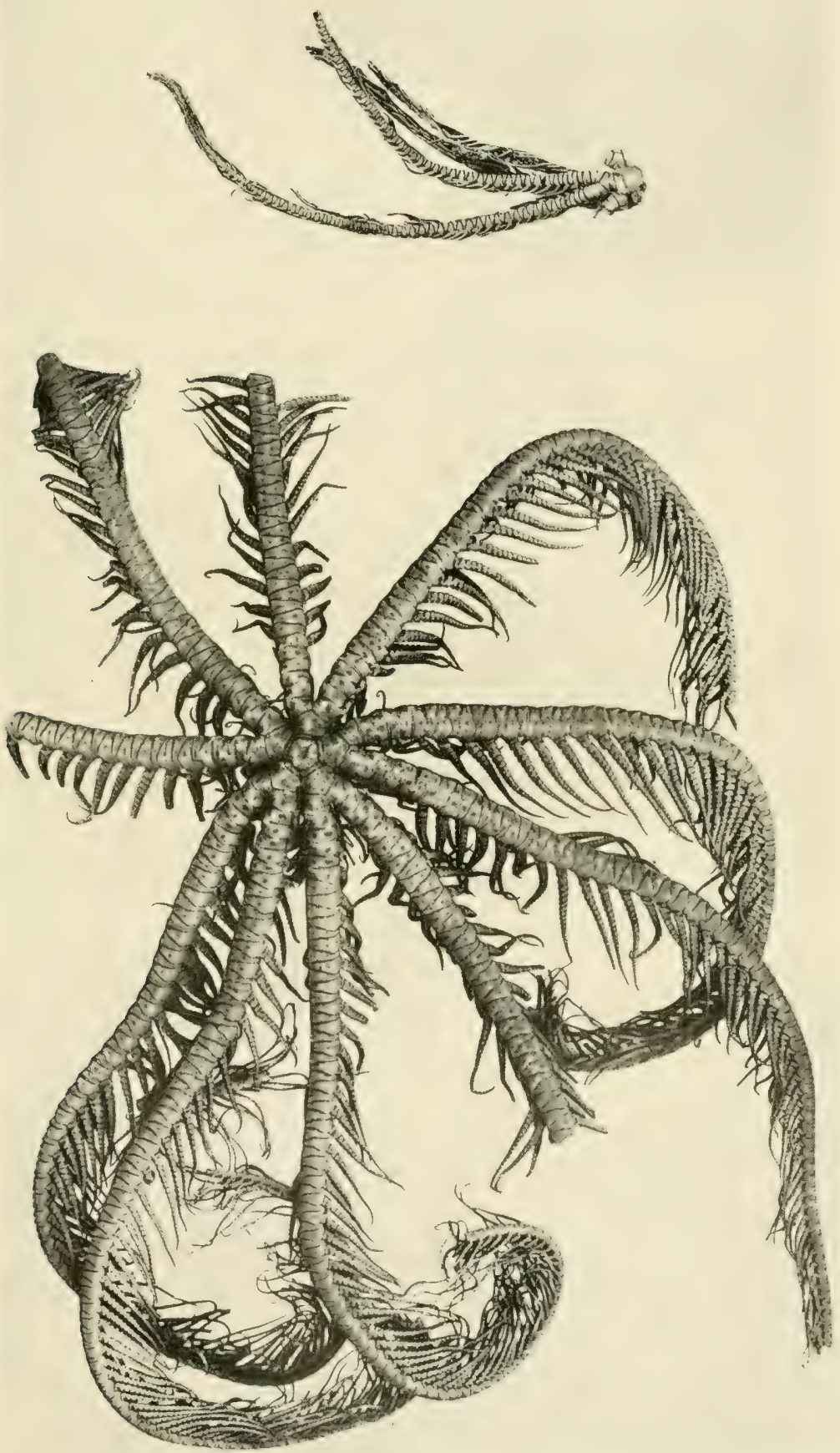

E. A. Briggs, Austr. Mus., photo. 




\section{EXPLANATION OF PLATE III.}

Fig. 1.-Oreometra pericalles, sp. nov. Photograph of the holotype from thirteen miles north by west of Double Island Point, Queensland, 25-26 fathoms. Natural size.

Fig. 2.-Comanthus perplexum, sp. nov. Photograph of the holotype from eleven miles south by east of Ballina.. New south Wales, 27-28 fathoms. Natural size. 
BIOL. RESULTS “ENDEAVOUR," VoL. IV.

Plate III.

1
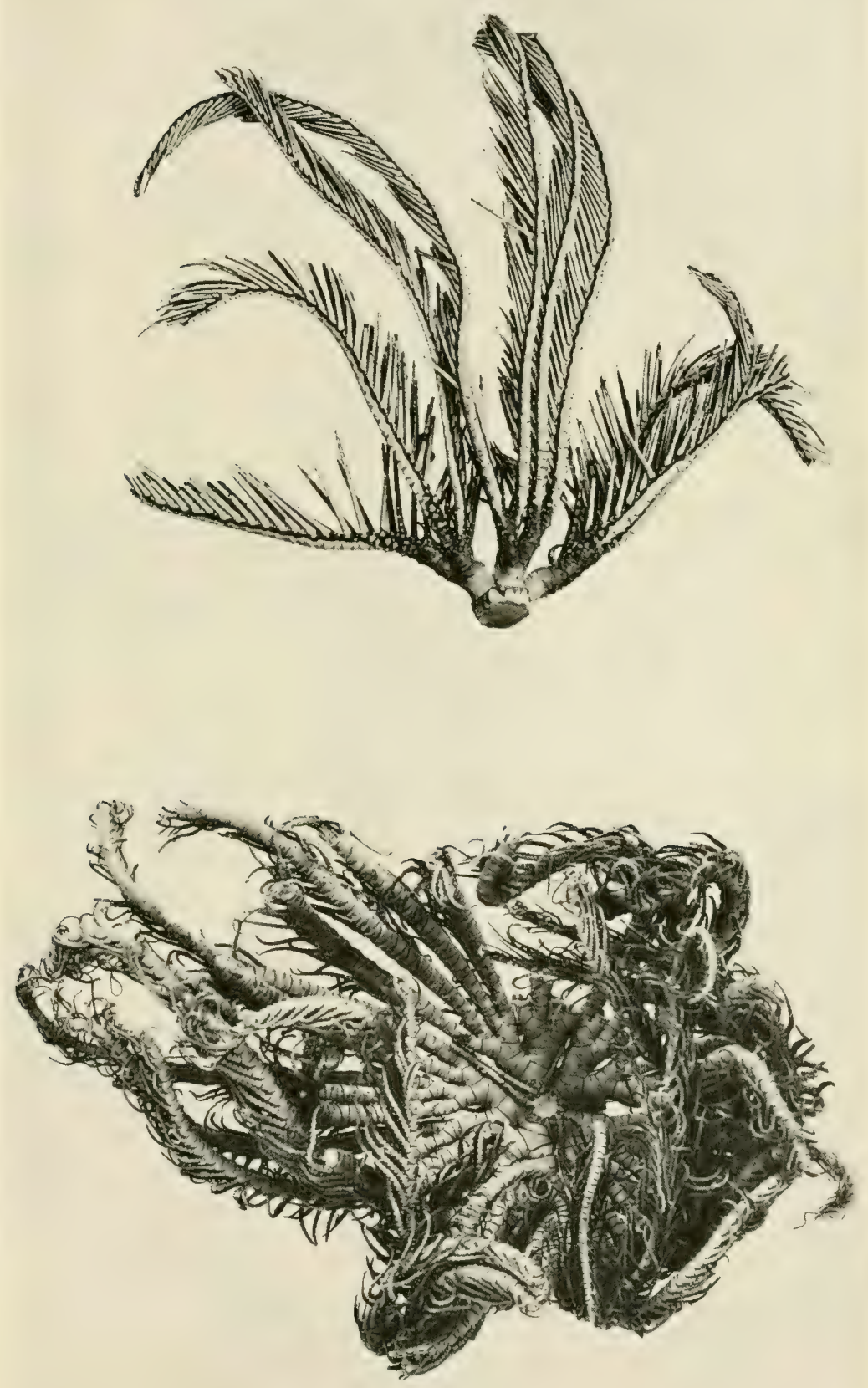




\section{EXPIAANATION OF PLATE IV.}

Fig. 1.-Comanthus plectrophorum, sp. nov. Photograph of the holotype from east of Flinders Island, Bass Strait, 100-300 fathoms. Natural size.

Fir. 2.-Cosmiometra dasybrachia, sp. nov. Photograph of the holotype from east of Flinders Island, Bass Strait, 70-100 fathoms. Natural size.

Fig. 3.-Comanthus spanoschistum, sp. nov. Photograph of the holotype from east of Babel Island, Bass Strait, $60-70$ fathoms. Natural size. 

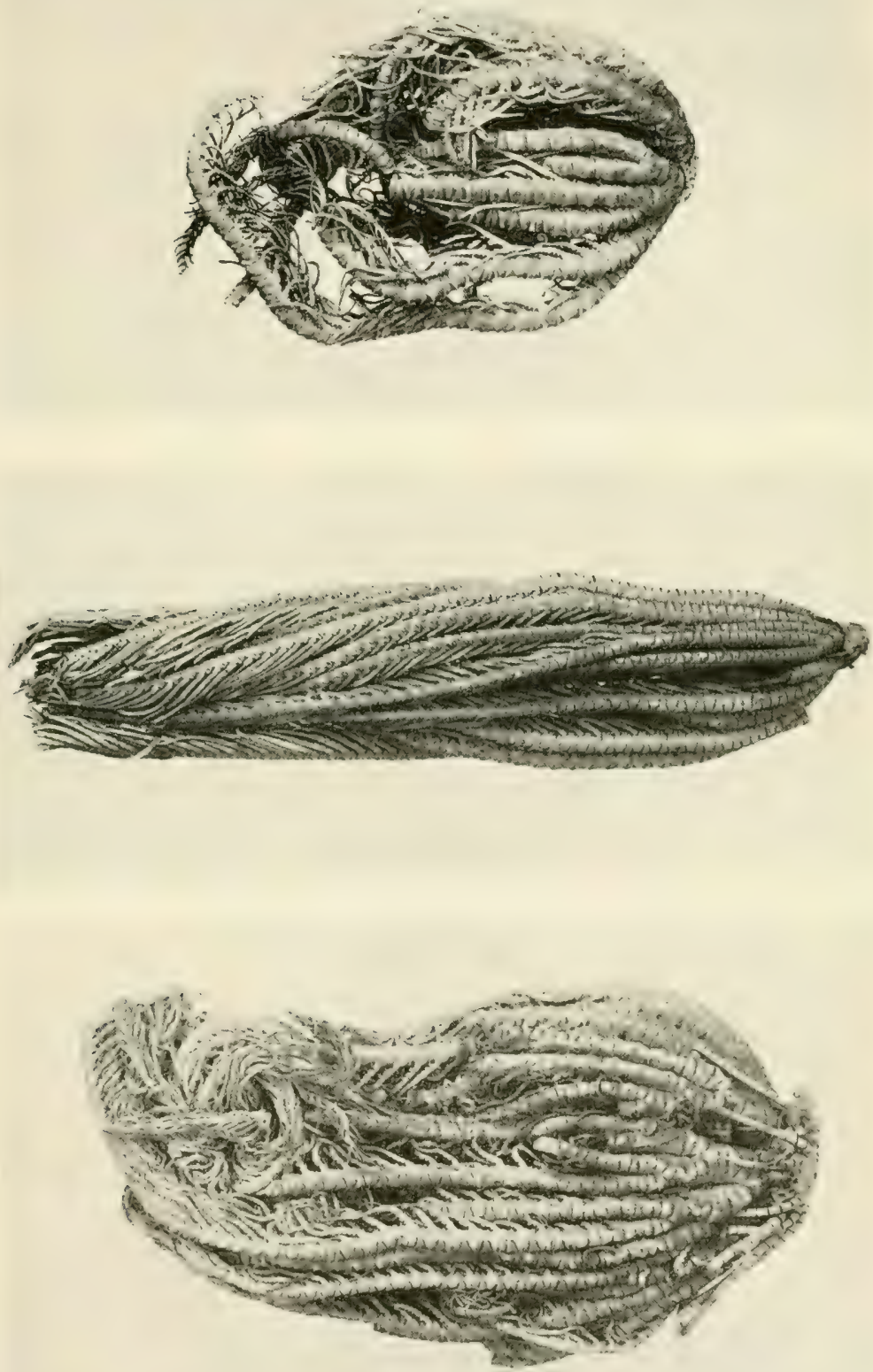


EXPLANATION OF PLATE V.

Luidia maculata, Müller and Troschel. Photograph of a specimen from the coast of New South Wales. Abactinal view. One-fourth natural size. 


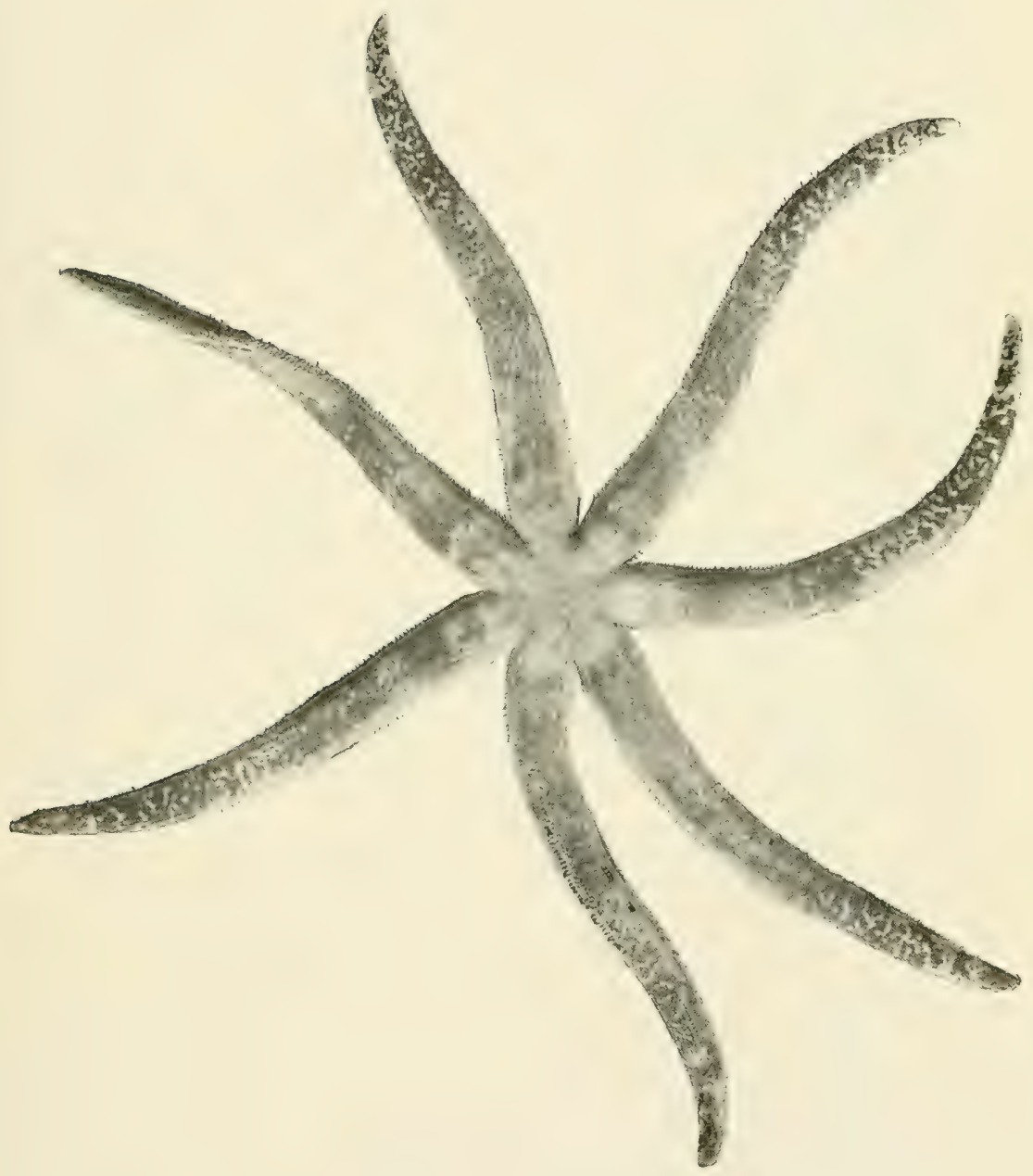

H. Barnes, Junr., Austr. Mus., photo. 




\section{EXPLANATION OF PLATE VI.}

Fig. 1.-Lonchotaster magnificus, sp. nov. Photograph of the holotype from the Great Australian Bight, 80-120 fathoms. Abactinal view. Two-fifths natural size.

Fig. 2.-Actinal view of same specimen as Fig. 1. 


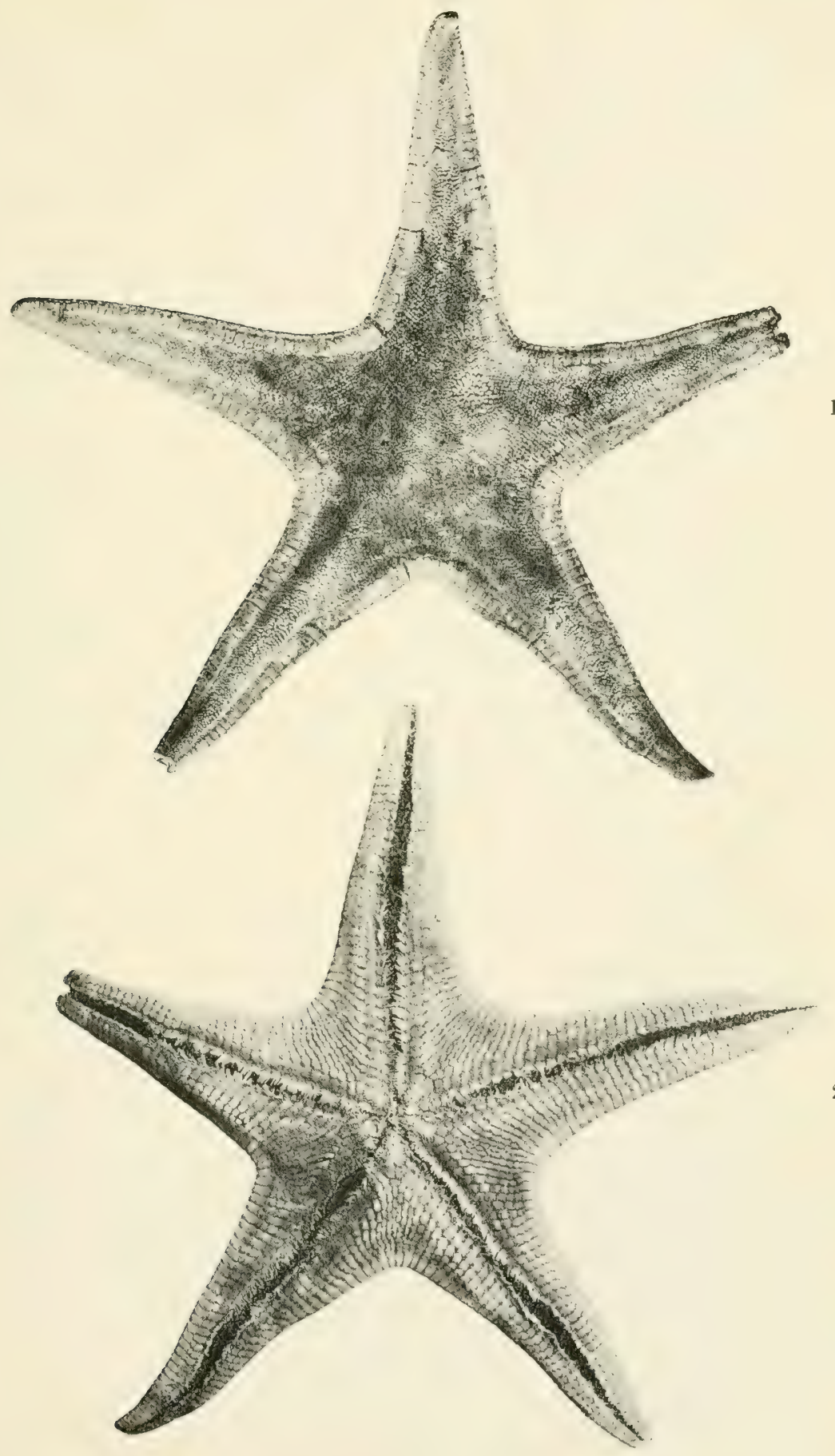

E. A Briggs, Austr. Mus, photo. 




\section{EXPLANATION OF PLATE VII.}

Fig. 1.-Mimaster gracilis, sp. nov. Photograph of the holotype from south of Gabo Island, Victoria, 200 fathoms. Abactinal view. Natural size.

Fig. 2.-Actinal view of same specimen as Fig. 1 . 


$$
\begin{aligned}
& x \\
& x
\end{aligned}
$$





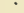


EXPLANATION OF PLATE VIII.

Fig. 1.-Nymphaster pentagonus, sp. nov. Photograph of the holotype from the Great Australian Bight, $129^{\circ} 28^{\prime}$ E. 250-450 fathoms. Abactinal view. Natural size.

Fiy. 2.-Actinal view of same specimen as Fig. 1. 


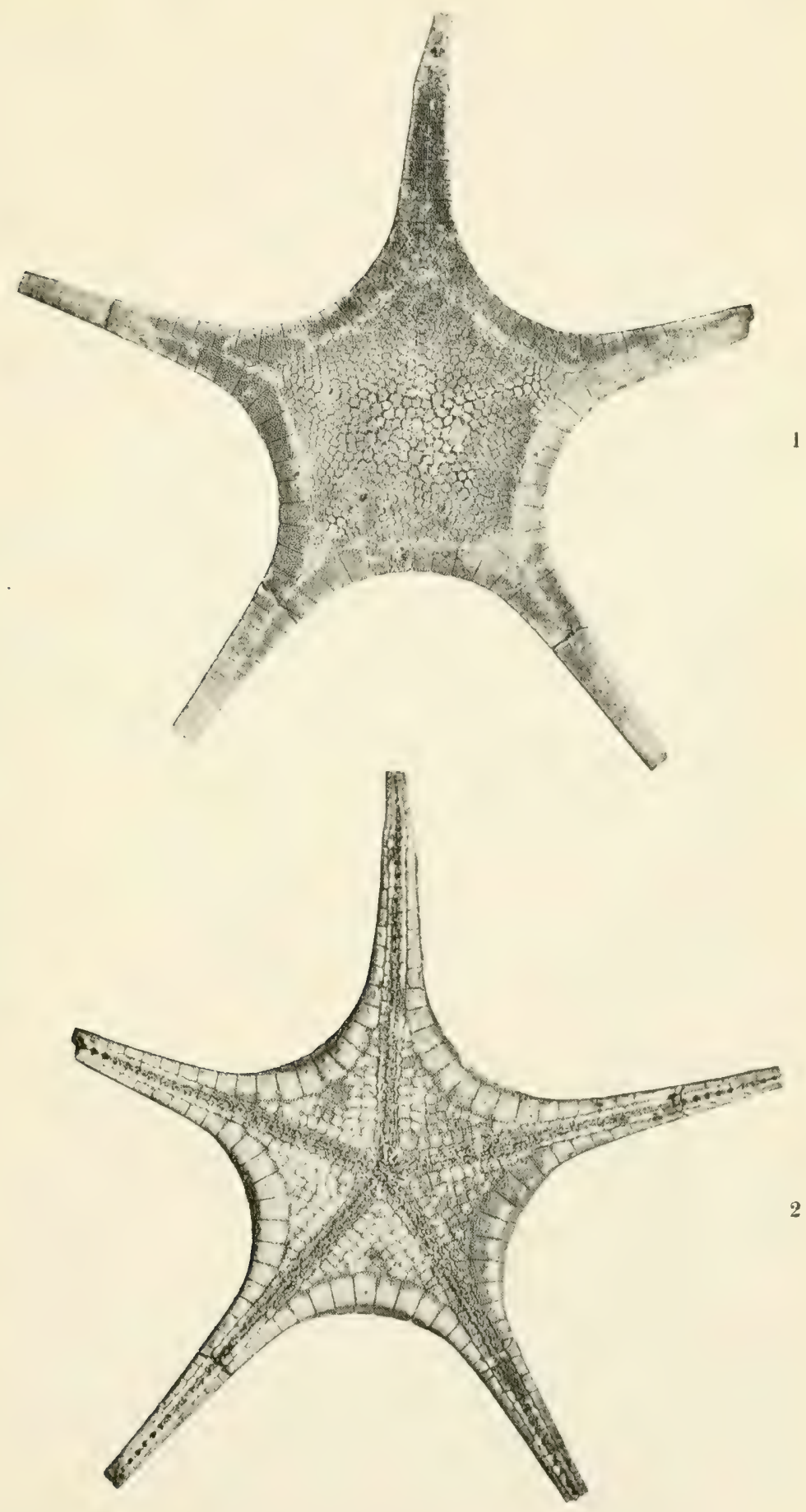

E. A. Brtggs, Austr. Mus., photo. 



\section{EXPLANATION OF PLATE IX.}

Fig. 1.-Mediaster australiensis, sp. nov. Photograph of the holotype from the east coast of Flinders Island, Bass Strait, 40 fathoms. Abactinal view. Five-eighths natural size.

Fig. 2.-Actinal view of same specimen as Fig. 1. 
BIOL. RESULTS "ENDEAVOUR,” Vol. IV.

Plate IX.

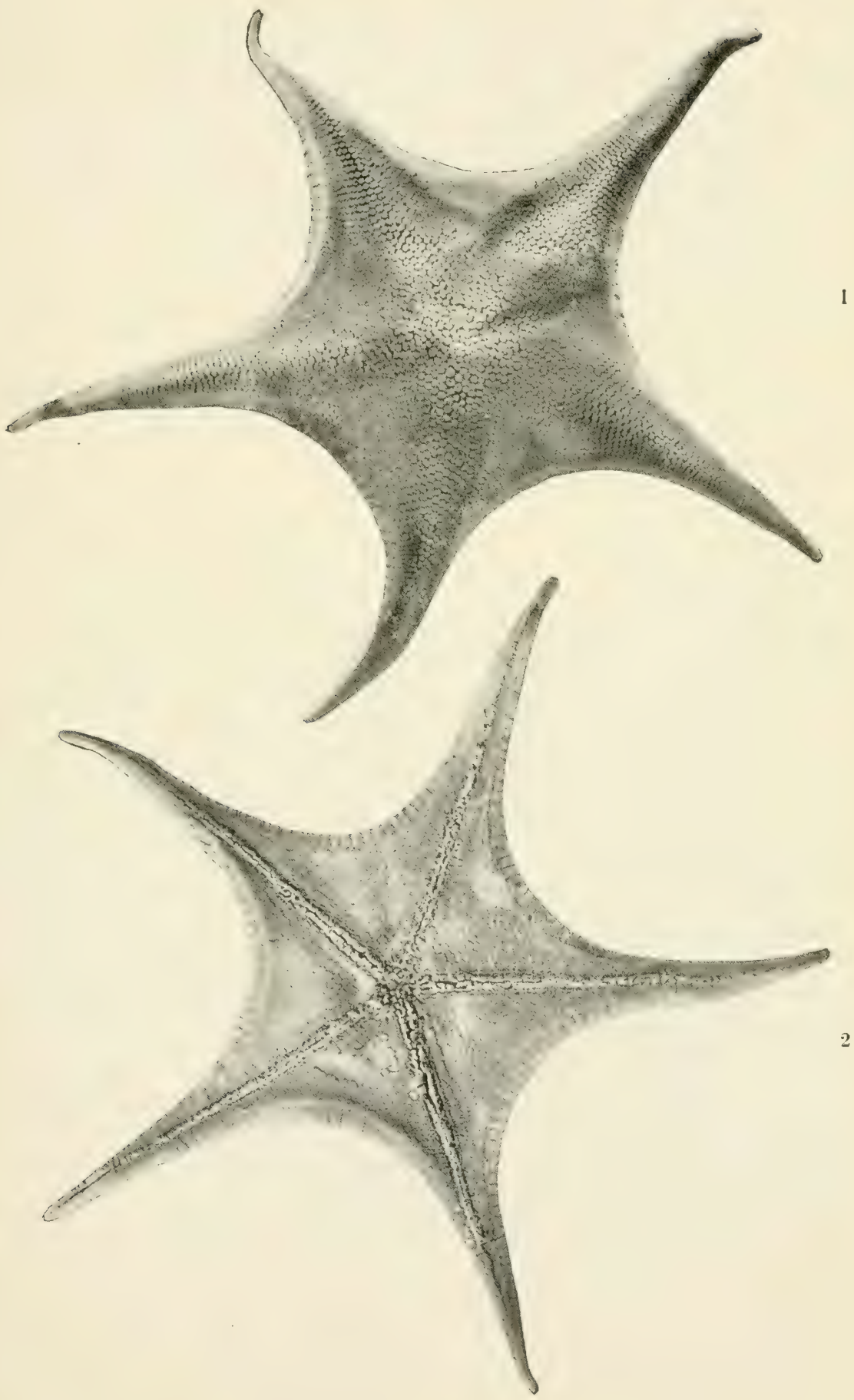

H. Barnes, Junr., Austr. Mus., photo. 




\section{EXPLANATION OF PLATE X.}

Fig. 1.-Mediaster monacanthus, sp. nov. Photograph of the holotype from six miles east of Cape Hawke, New South Wales, 47-50 fathoms. Abactinal view. Onehalf natural size.

Fig. 2.-Mediaster monacanthus, sp. nov. Photograph of the paratype from six miles east of Cape Hawke, New South Wales, 47-50 fathoms. Actinal view. Onehalf natural size. 


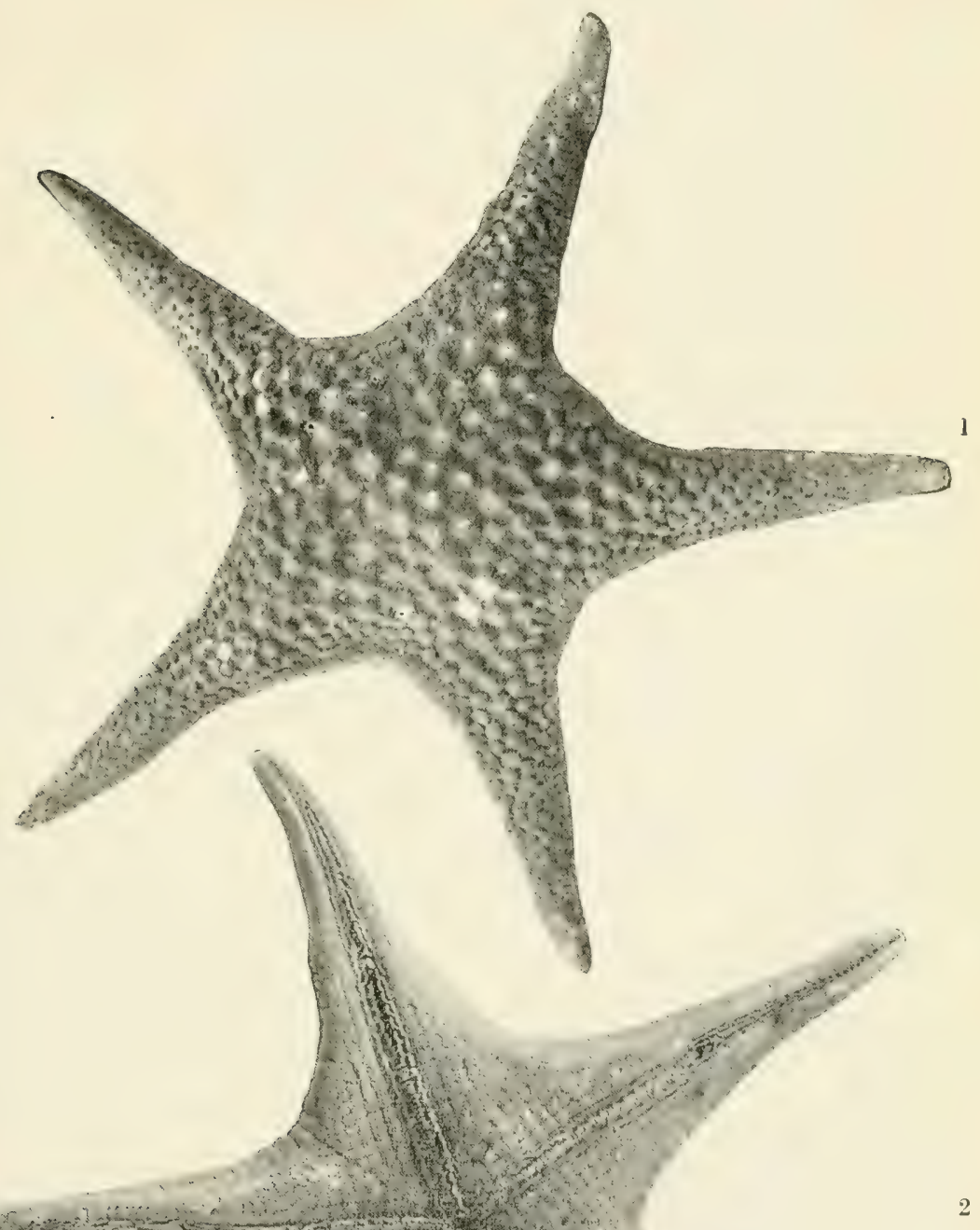

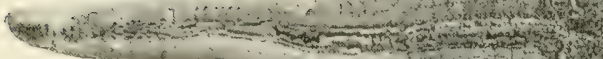

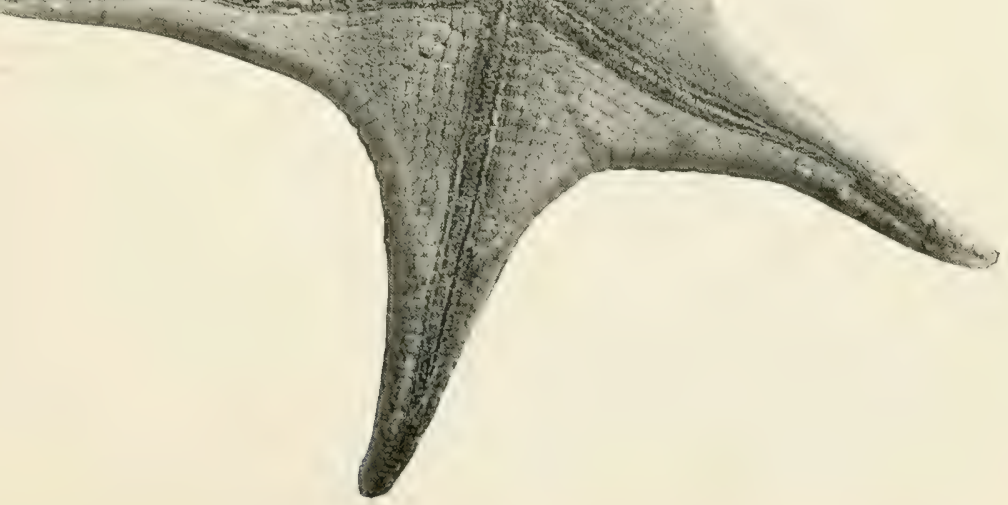

H. Barnes, Junr., Austr. Mus., photo 



\section{EXPLANATION OF PLATE XI.}

Fig. 1.-Calliaster spinosus, sp. nov. Photograph of the holotype from the Eastern Slope, Bass Strait, 80-200 fathoms. Abactinal view. One-half natural size.

Fig. 2.-Actinal view of same specimen as Fig. 1. 


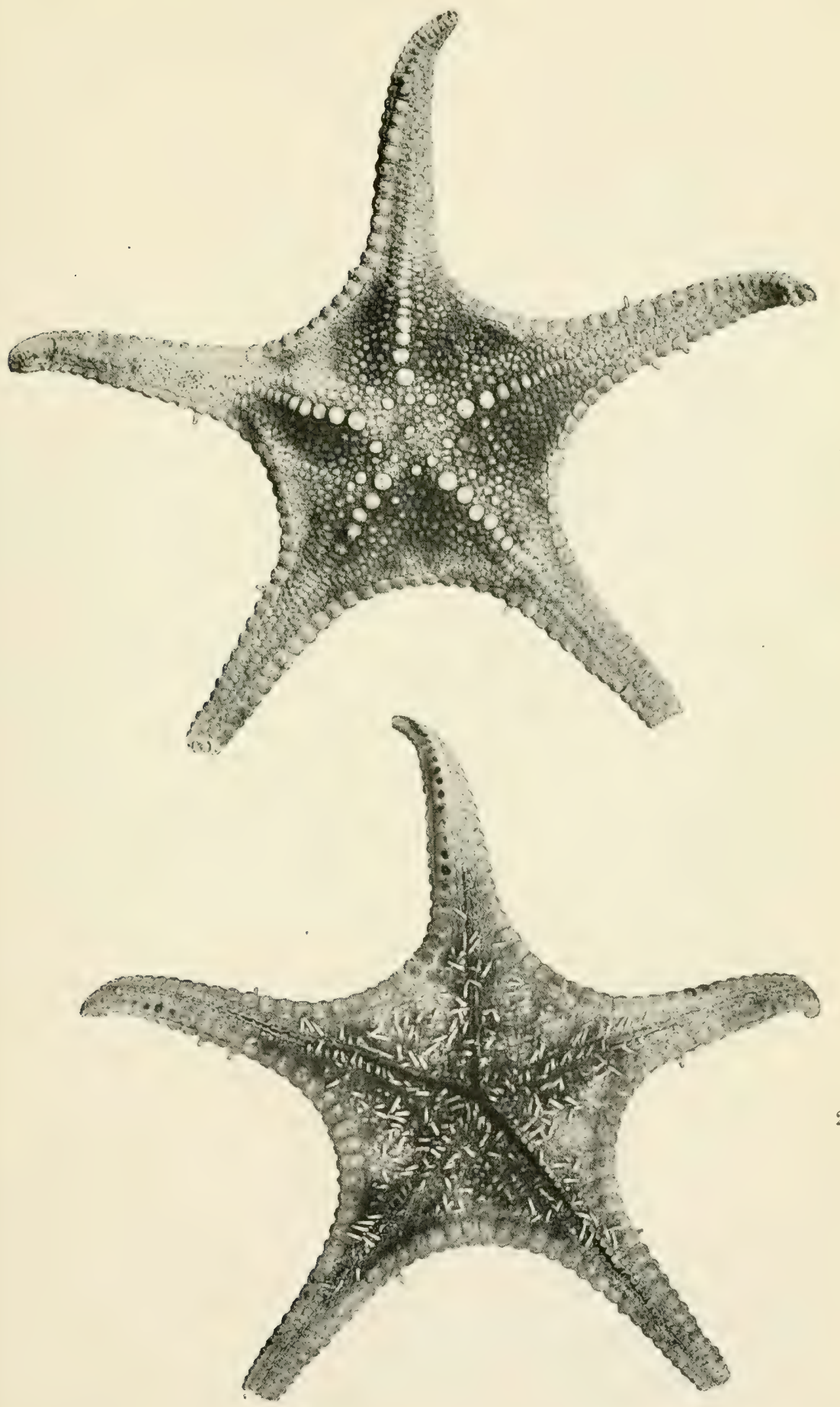

E. A. Briggs, Austr. Mus., photo. 



\section{EXPLANATION OF PLATE XII.}

Fig. 1.-Stellaster incei, Gray. Photograph of a specimen from eleven miles south by east of Ballina, New South Wales, 27-29 fathoms. Abactinal view. Ninetenths natural size.

Fig. 2.-Actinal view of same specimen as Fig. 1. 


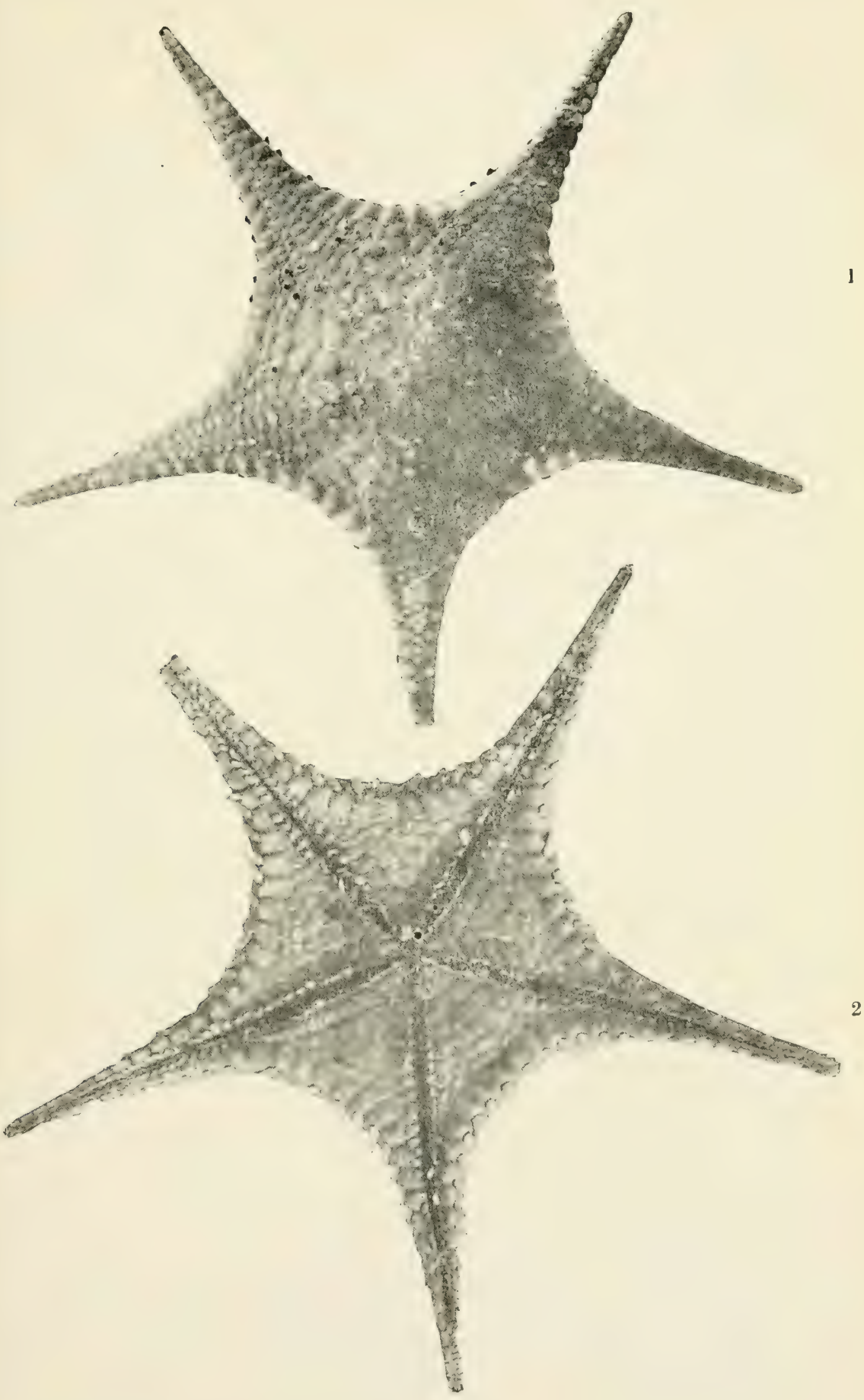

H. Barnes, Junr., Austr. Mus., photo. 




\section{EXPLANATION OF PLATE XIII.}

Fig. 1.- Stellaster inspinosus, sp. nov. Photograph of the holotype from between Geraldton and Cape Naturaliste, Western Australia. Abactinal view. Natural size.

Fig. 2 -Actinal view of same specimen as Fig. 1. 


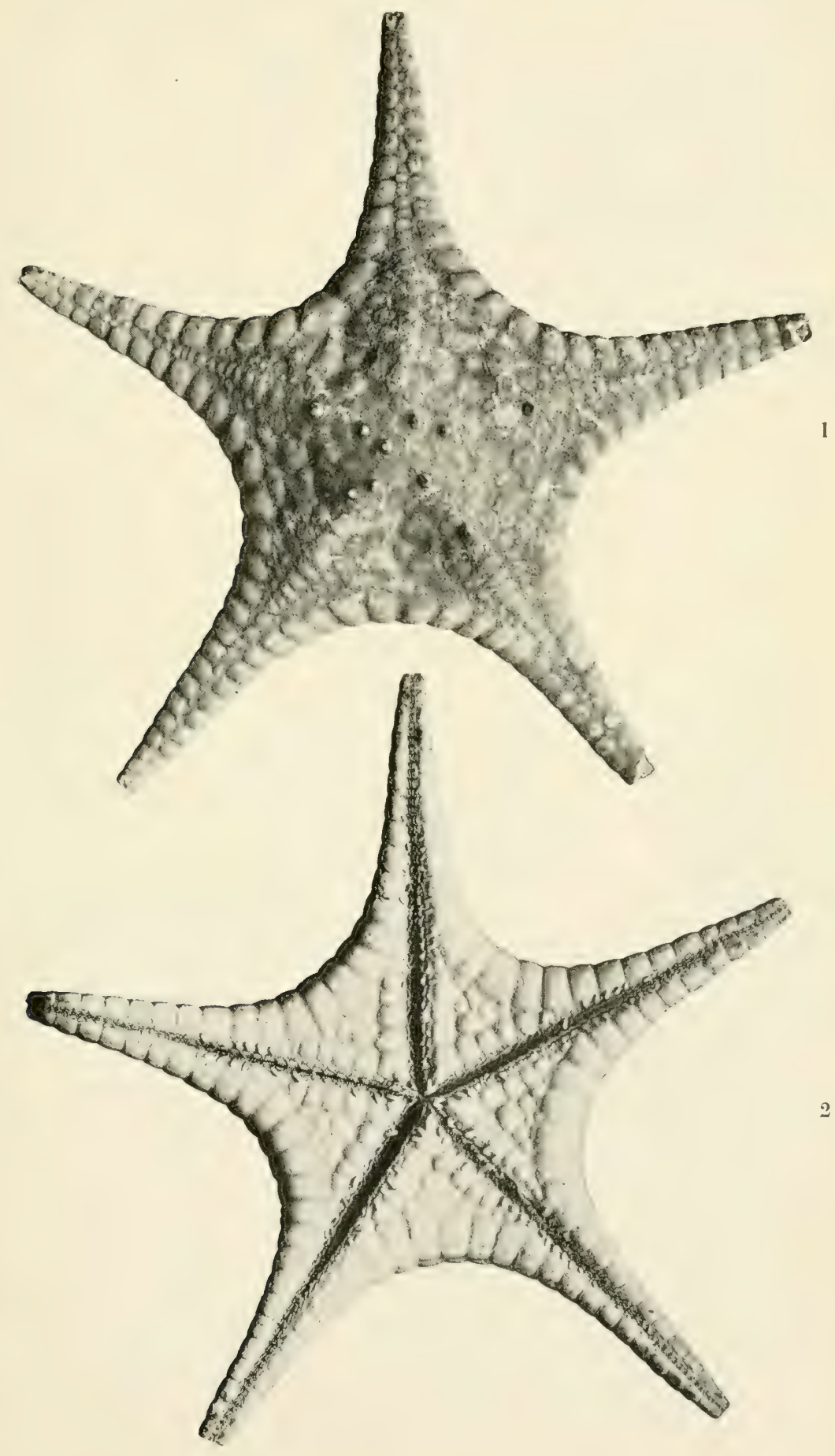

E. A. Briggs, Austr. Mus, photo. 




\section{EXPLANATION OF PLATE XIV.}

Fig. 1.-Fromia polypora, sp. nov. Photograph of the holotype from east of Maria Island, Tasmania, 78 fathoms. Abactinal view. Two-thirds natural size.

Fig. 2.-Actinal view of same specimen as Fig. 1. 


$$
\text { 炎 }
$$






\section{EXPLANATION OF PLATE XV.}

Fig. 1.-Ophidiaster confertus, sp. nov. Photograph of the holotype from Lord Howe Island, South Pacific Ocean. Abactinal view. Three-fourths natural size.

Fig. 2.-Actinal view of same specimen as Fig. 1. 


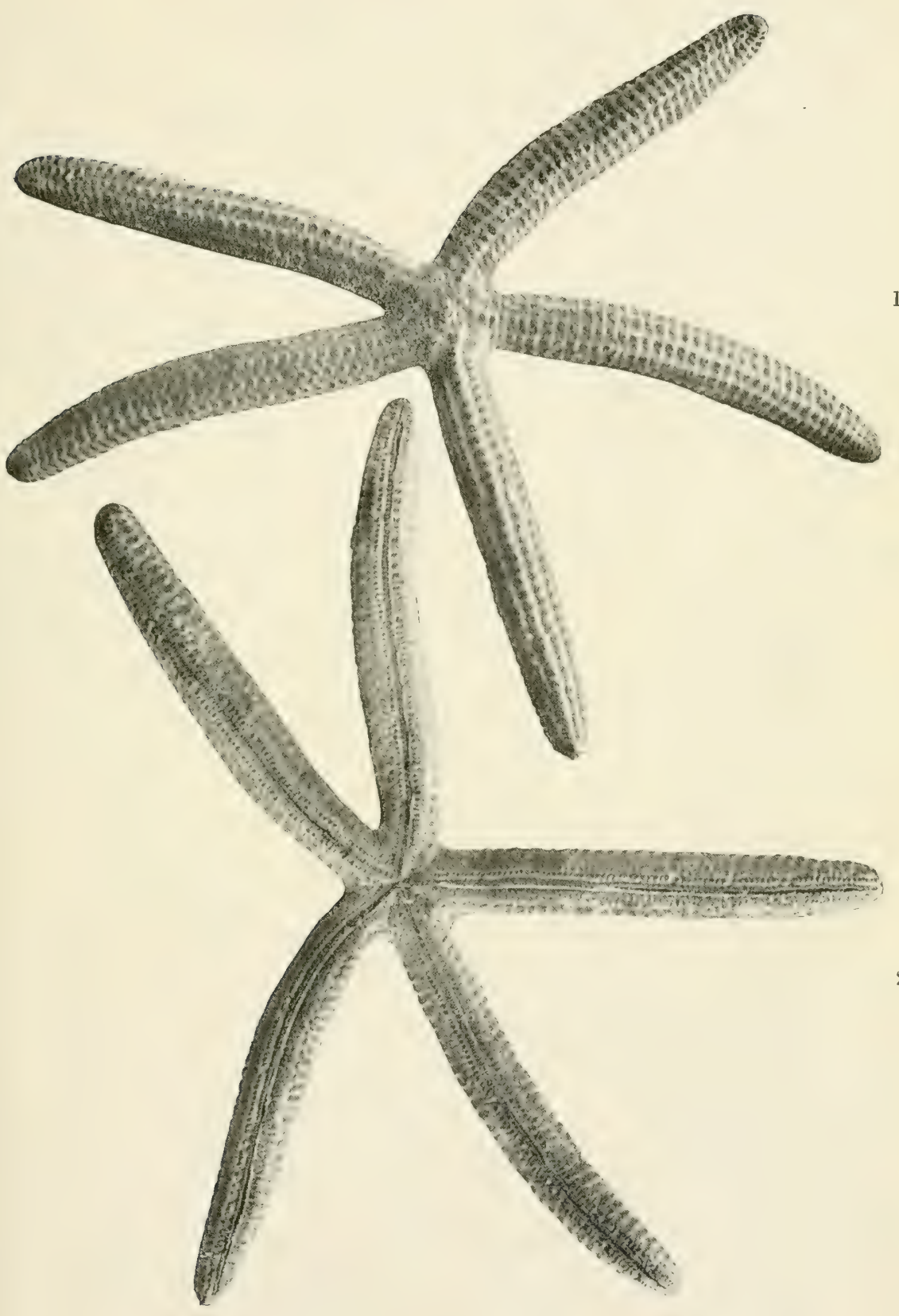

H. Barnes, Junr., Austr. Mus., photo. 




\section{EXPLANATION OF PLATE XVI.}

Fig. 1.-Pseudophidiaster rhysus, sp. nov. Photograph of the holotype from the Great Australian Bight, 80-120 fathoms. Abactinal view. One-half natural size.

Fig. 2.-Actinal view of same specimen as Fig. 1. 


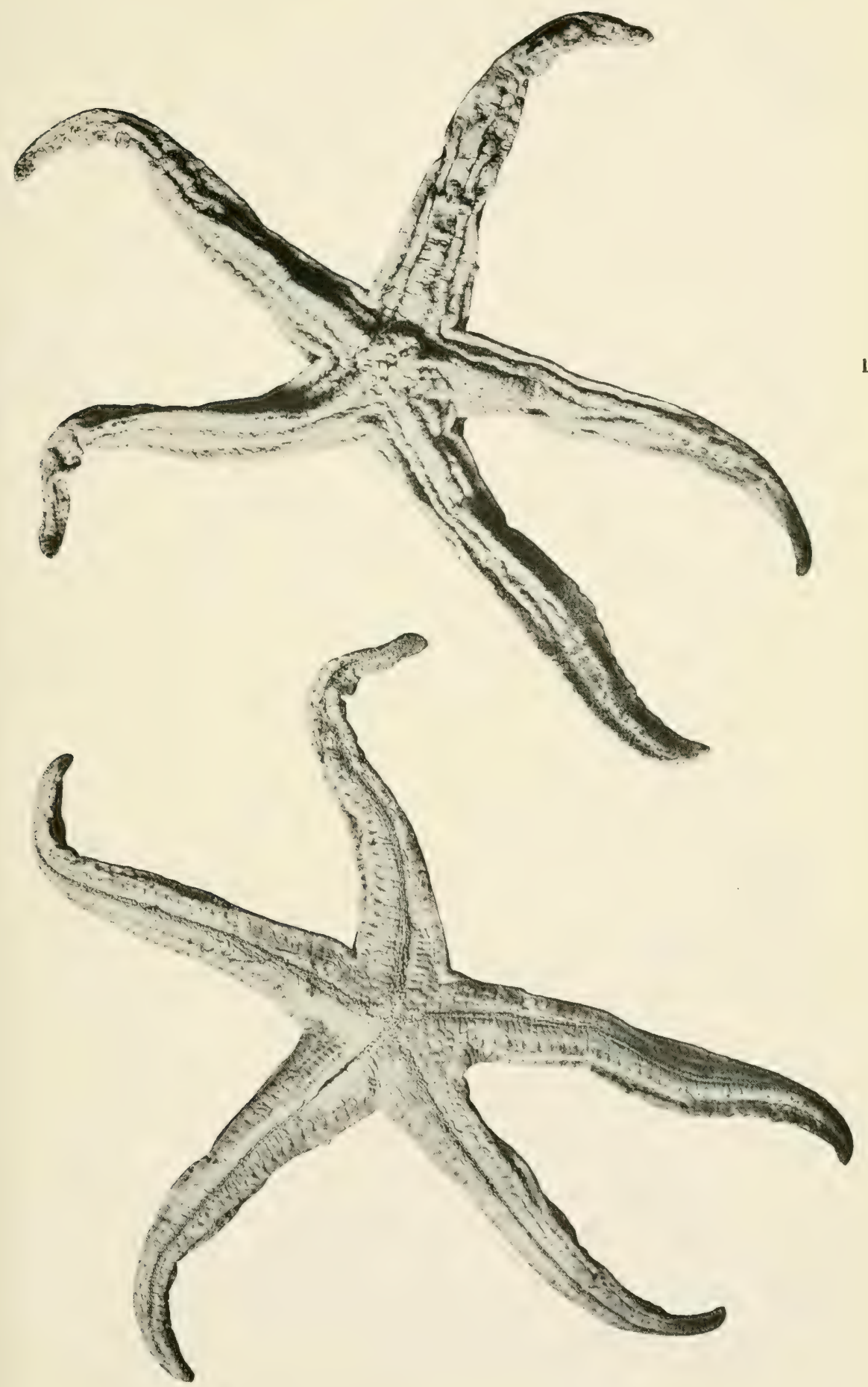

E. A. Briggs, Austr. Mus., photo. 




\section{EXPLANATION OF PLATE XVII.}

Fig. 1.-Aisterina atyphoida, sp. nov. Photograph of the holotype from fifteen miles north-west of Cape Jervis, South Australia, 17 fathoms. Abactinal view. Four times natural size.

Fig. 2.-Actinal view of same specimen as Fig. 1 . 

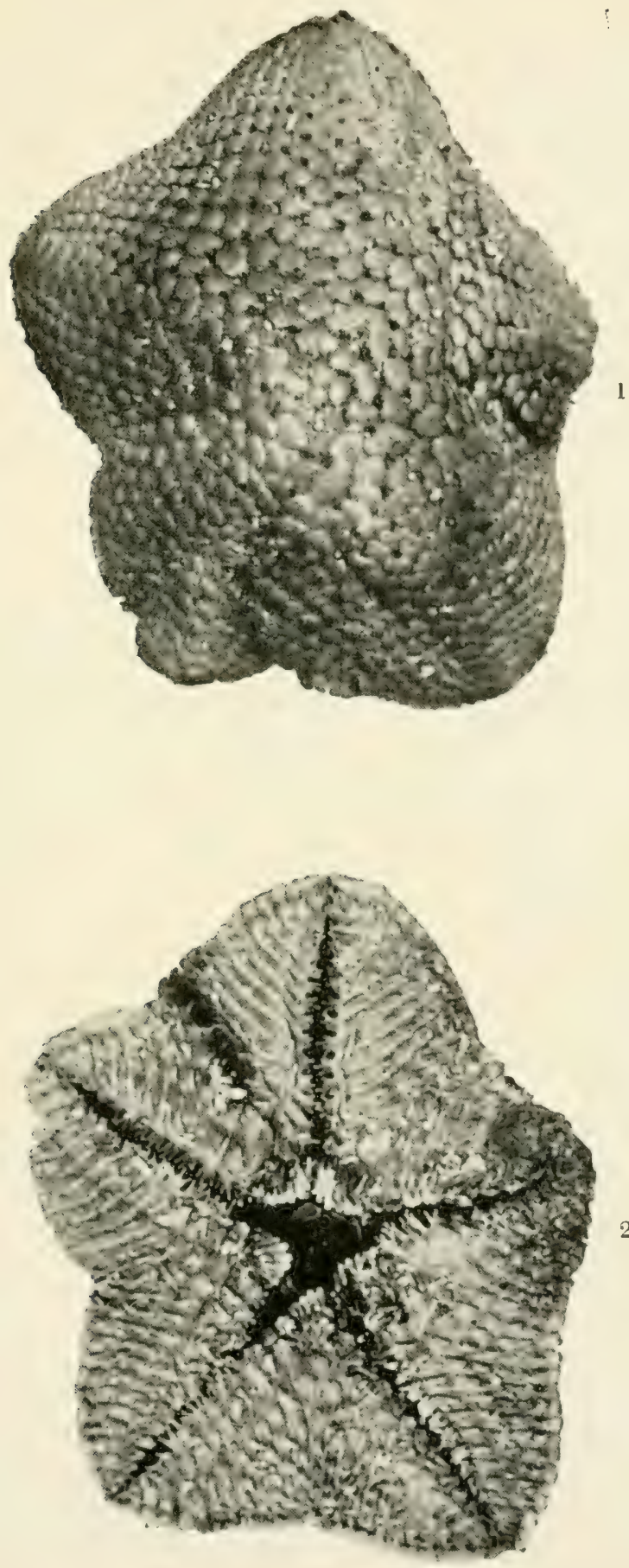



\section{EXPLANATION OF PLATE XVIII.}

Fig. 1.-Pteraster tetracanthus, sp. nov. Photograph of the holotype from south-east of Cape Everard to south of Gabo Island, Victoria, 90-150 fathoms. Abactinal view. Natural size.

Fig. 2.-Actinal view of same specimen as Fig. 1 .

Fig. 3.-Asterina leptalacantha, sp. nov. Photograph of the holotype from Masthead Island, Queensland. Abactinal view. Twice natural size.

Fiy. 4.-Actinal view of same specimen as Fig. 3.

Fig. 5.-Crossaster multispinus, sp. nov. Photograph of the holotype from between Gabo Island, Victoria, and Disaster Bay, New South Wales, 50-100 fathoms. Abactinal view. Natural size.

Fig. 6.-Actinal view of same specimen as Fig. 5. 

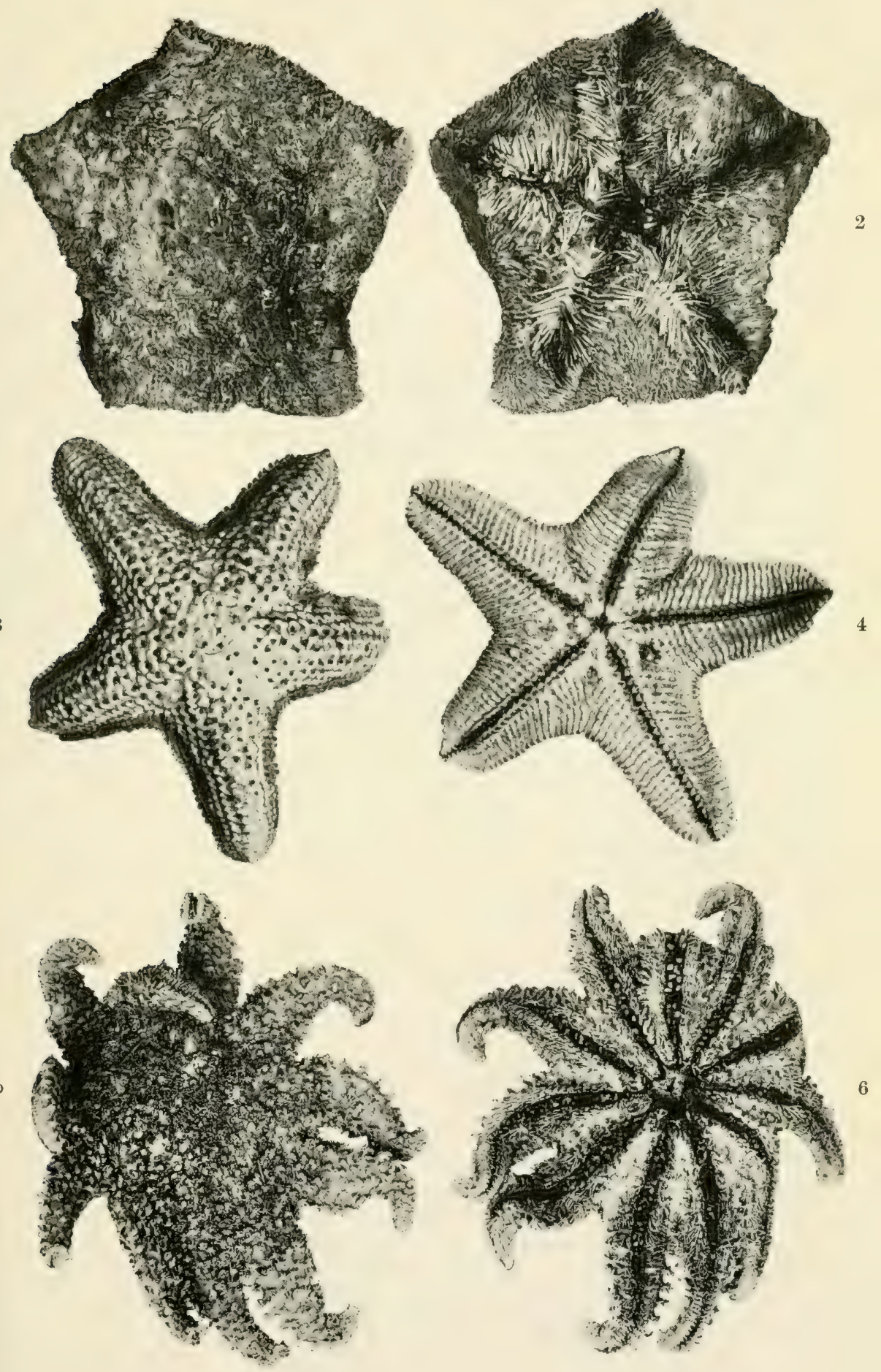

E. A. Briggs, Austr. Mus., photo. 

EXPLANATION OF PLATE XIX.

Fig. 1.-Echinaster acanthodes, sp. nov. Photograph of the holotype from twenty-five miles south-east of Double Island Point, Queensland, 33 fathoms. Abactinal view. Six-sevenths natural size.

Fic. 2.-Actinal view of same specimen as Fig. 1 . 


$$
\forall
$$






\section{EXPLANATION OF PLATE XX.}

Fig. 1.Echinaster cridanella, Müller and 'T'roschel. Photo. craph of a specimen from Nurray Island, Torres Strait. Abactinal view. Natural size.

Fir. 2.-Actinal view of same specimen as Fir. 1. 


$$
\text { 苏 }
$$




EXPLANATION OF PLATE XXI.

Fig. 1.-Echinaster eridanella, Müller and Trosehel. Photo. graph of a specimen with four rays from Mauritius. Abactinal view. Natural size.

Fig. 2.-Echinaster eridanella, Müller and T'roschel. Photograph of a specimen with seven rays from Bowen, Queensland. Abactinal view. Natural size. 


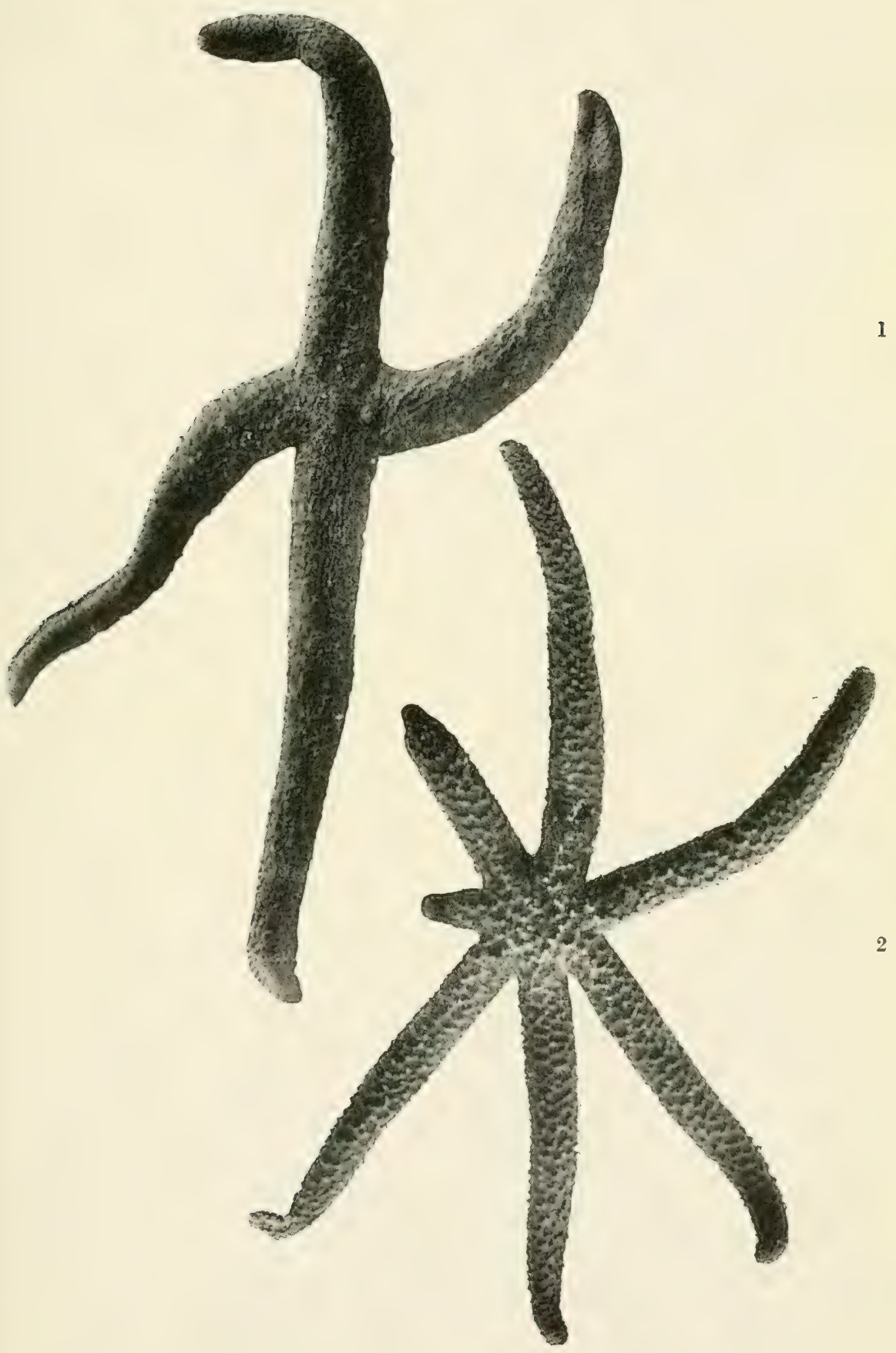

H. Barnes, Junr., Austr. Mus., photo. 


EXPLANATION OF PLATE XXII.

Echinaster glomeratus, sp. nov. Photograph of the holotype from off Cape Marsden, Kangaroo Island, South Australia, 17 fathoms. Abaetinal view. Twothirds natural size. 


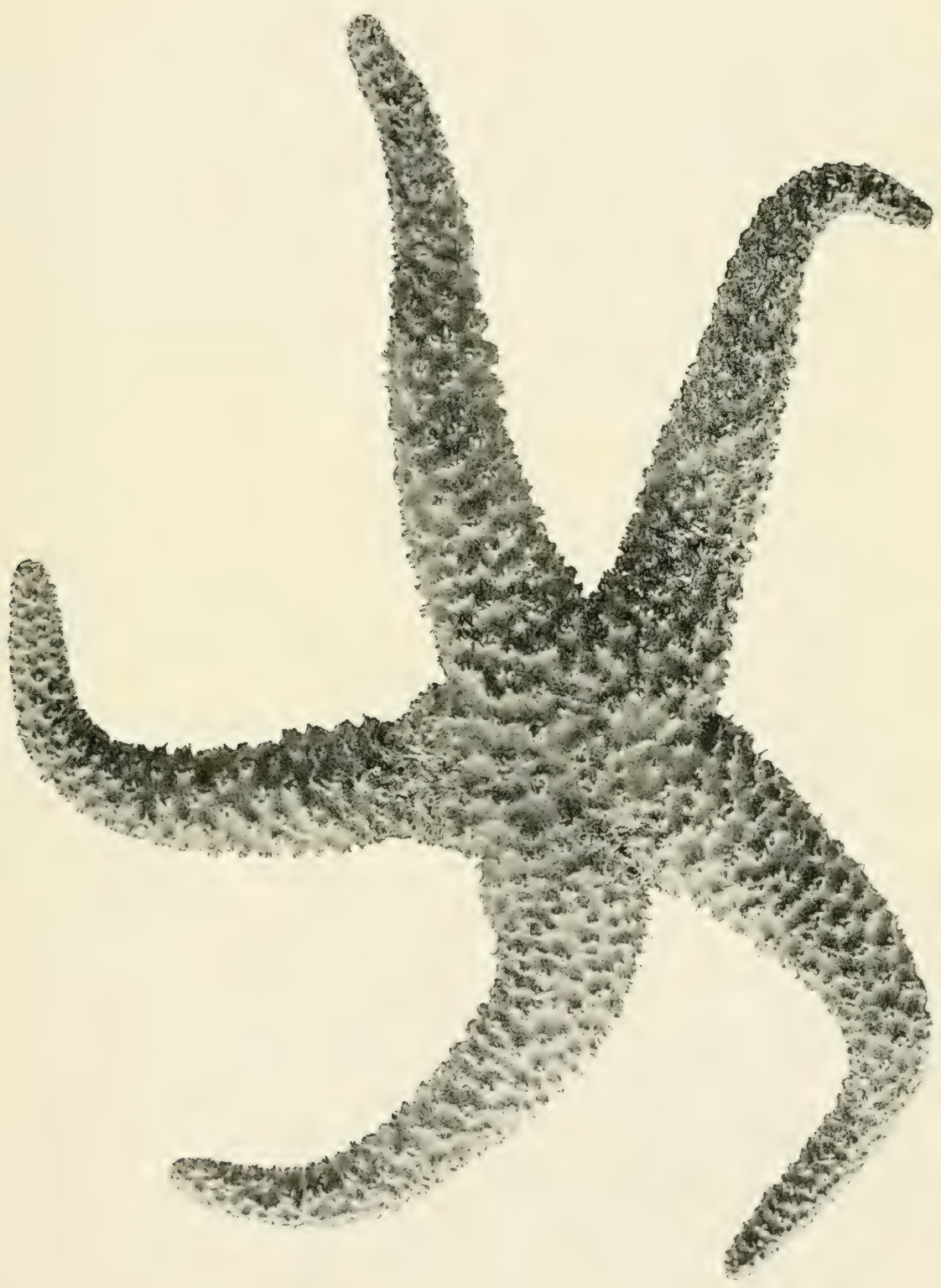

H." Barnes, Junr., Austr. Mus., photo. 

EXPLANA'ION OF PLATE XXIII.

Echinaster glomeratus, sp. nov. Photograph of the holotype from off Cape Marsden, Kangaroo Island, South Australia, 17 fathoms. Actinal view. Two-thirds natural size. 


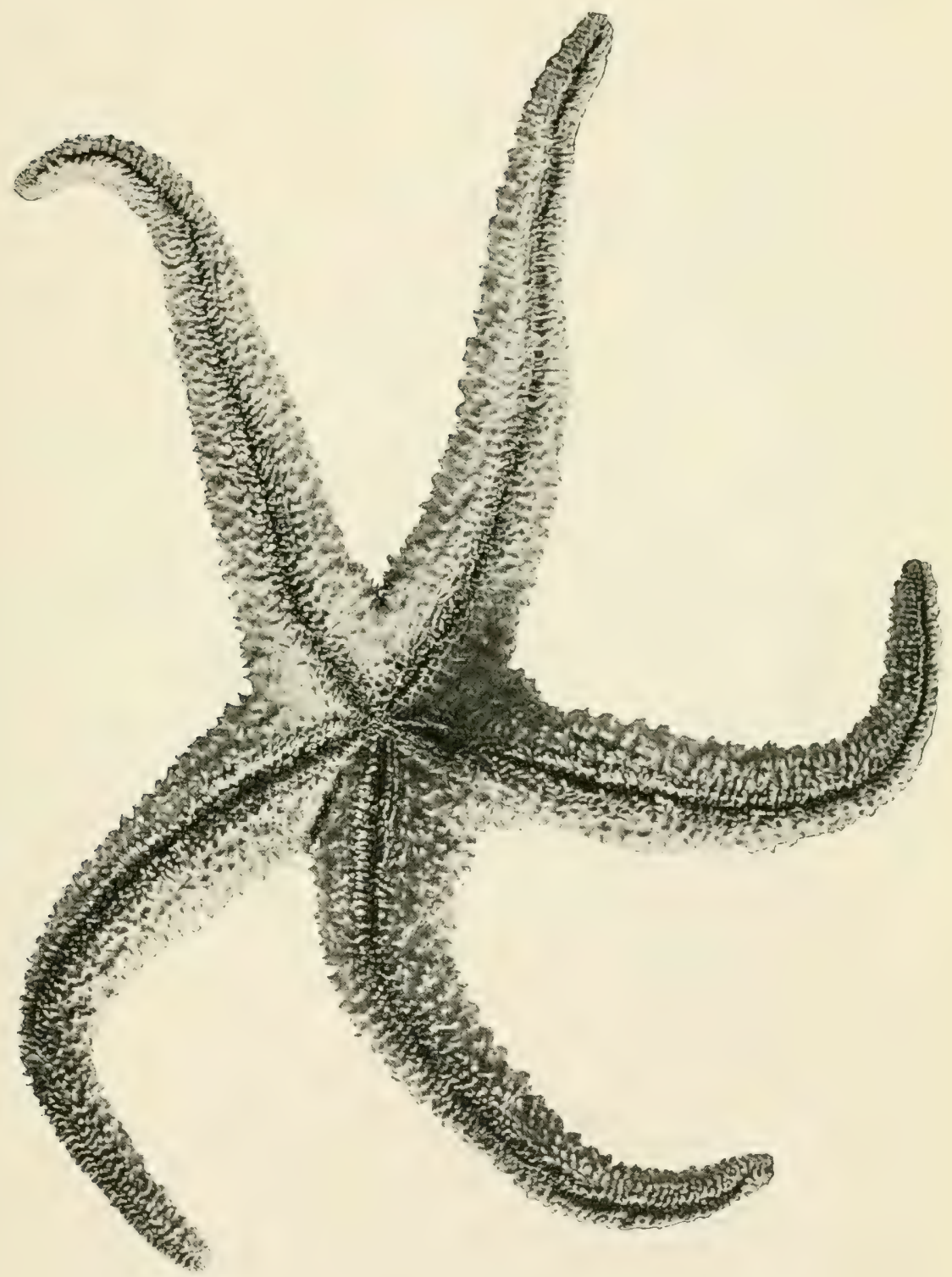

H. Barnes, Junr., Austr. Mus., photo. 


EXPLANATION OF PLATE XXIV.

Echinaster superbus, sp. nov. Photograph of the holotype from Broome, Western Australia. Abactinal view. Four-fifths natural size. 


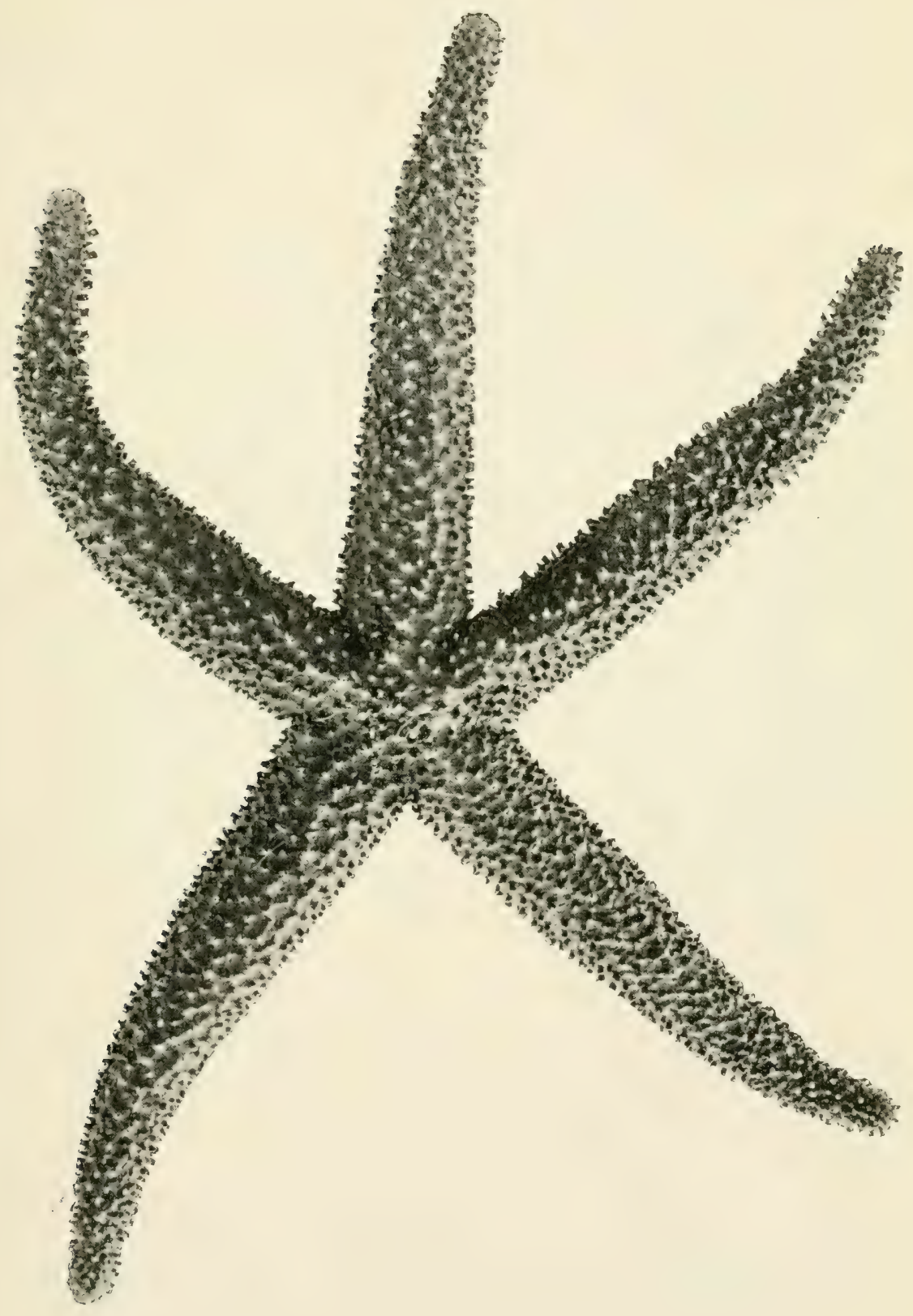

H. Barnes, Junr., Austr. Mus., photo. 


EXPLANATION OF PLATE XXV.

Echinaster superbus, sp. nov. Photograph of the holotype from Broome, Western Australia. Actinal view. Four-fifths natural size. 


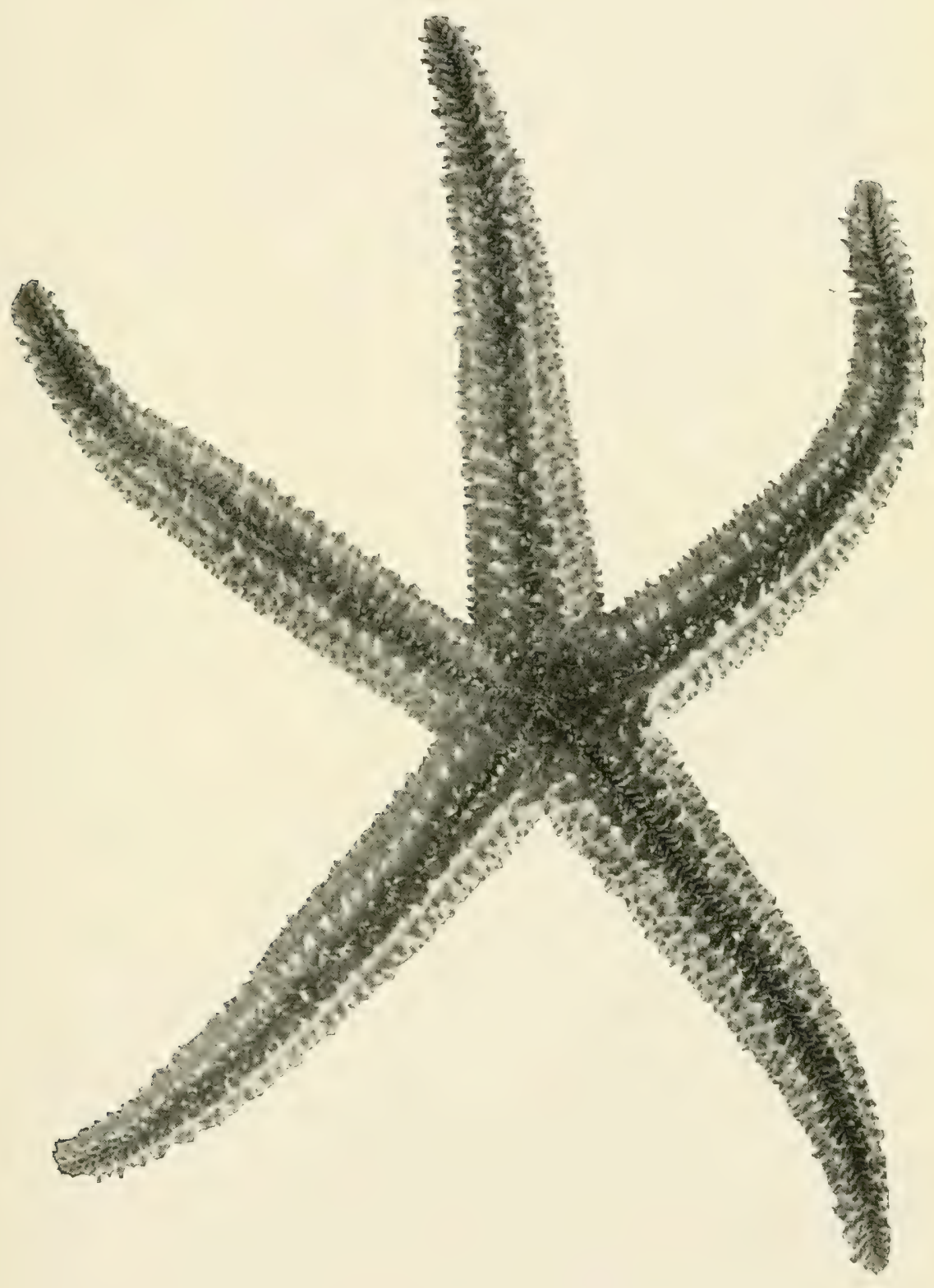

H. Barnes, Junr., Austr. Mus., photo. 




\section{EXPLANATION OF PLATE XXVI.}

Fig. 1.-Plectaster decanus (Müller and Troschel). Photograph of a specimen from off George Head, Port Jackson. New South Wales. Abactinal view. One-half natural size.

Fig. 2.-Actinal view of same specimen as Fig. 1. 


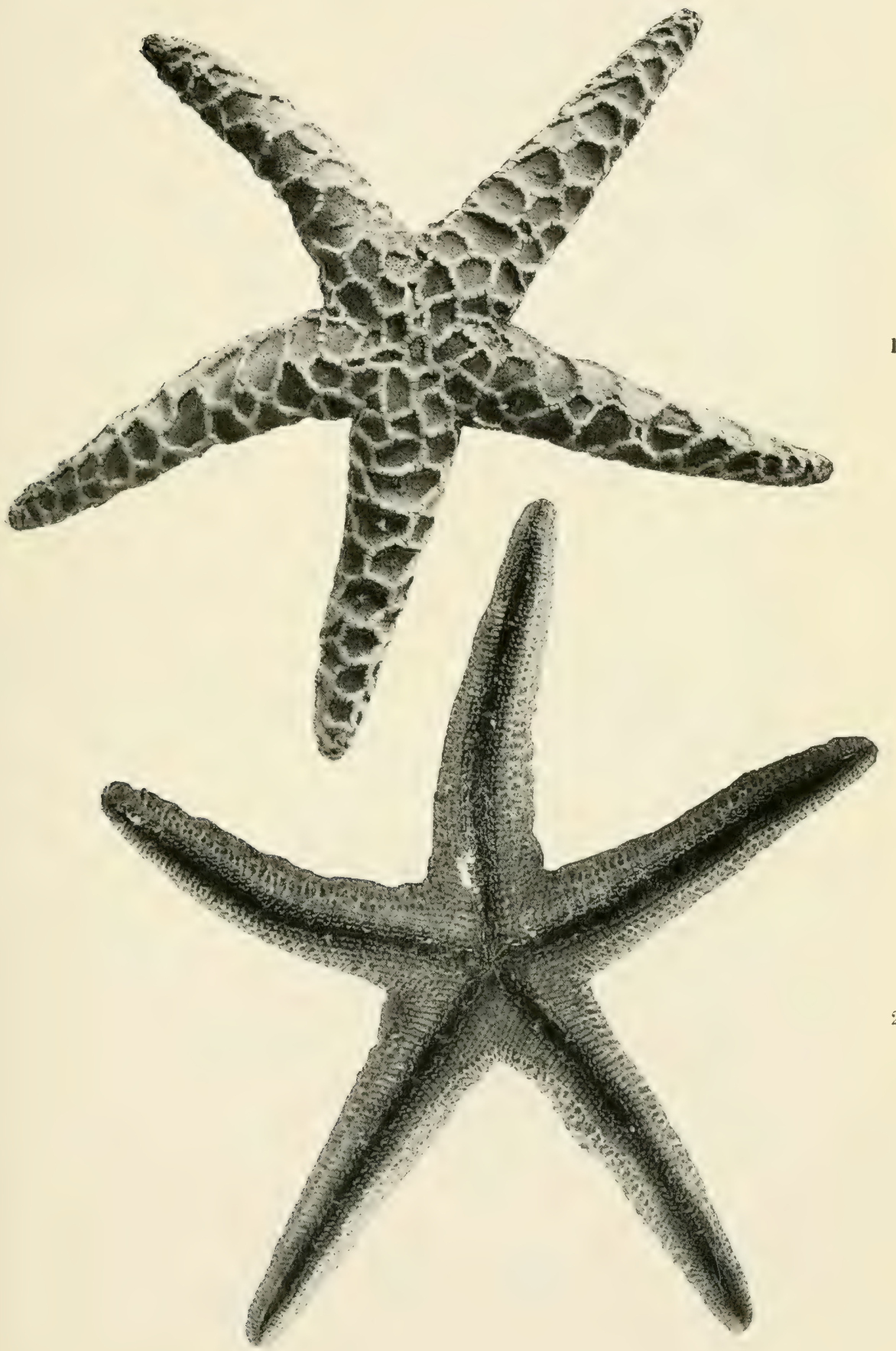

H. Barnes, Junr., Austr. Mus., photo. 




\section{EXPLANATION OF PLATE XXVII.}

Fig. 1.-Odinia australis, sp. nov. Photograph of the holotype from south-east of Cape Everard, Victoria, 200 fathoms. Abactinal view. Natural size.

Kij. 2. -Actinal view of same specimen as Fig. 1.

Fis. 3.-Pedicellaster reticulatus, sp. nov. Photograph of the holotype from east of Maria Island, Tasmania, 78 fathoms. Abactinal view. Twice natural size.

Fi.. 4.-Actinal view of same specimen as Fig. 3 . 

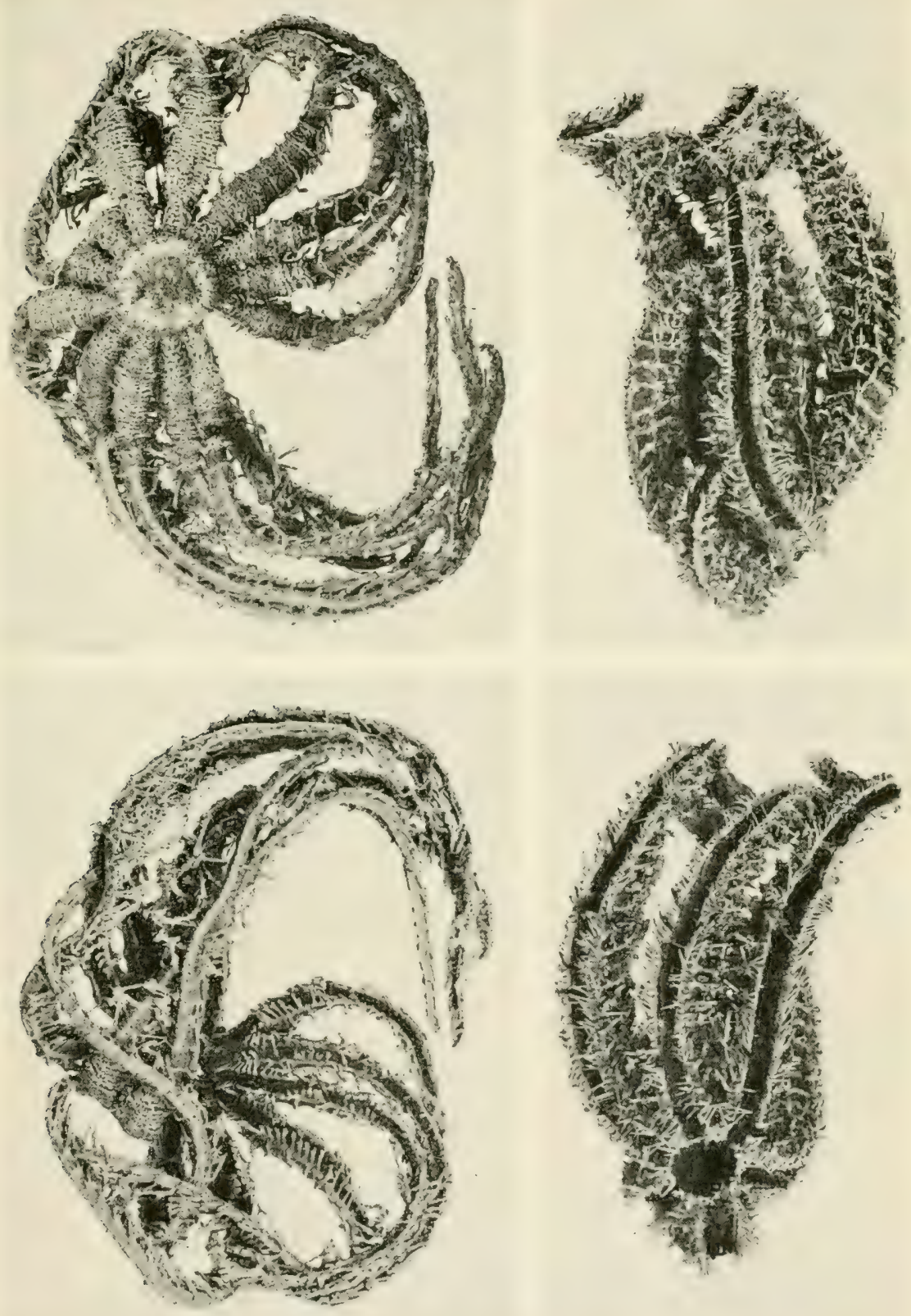


EXPLANATION OF PLATE XXVIII.

Fig. 1.-Zoroaster macracantha, sp. nov. Photograph of the holotype from the Great Australian Bight, $129^{\circ}$ $28^{\prime}$ E., 250-450 fathoms. Abactinal view. About one-half natural size.

Fig. 2.-Actinal view of same specimen as Fig. 1. 
BIOL. Results "ENDEavour," Vol. IV. Plate XXVIIT.

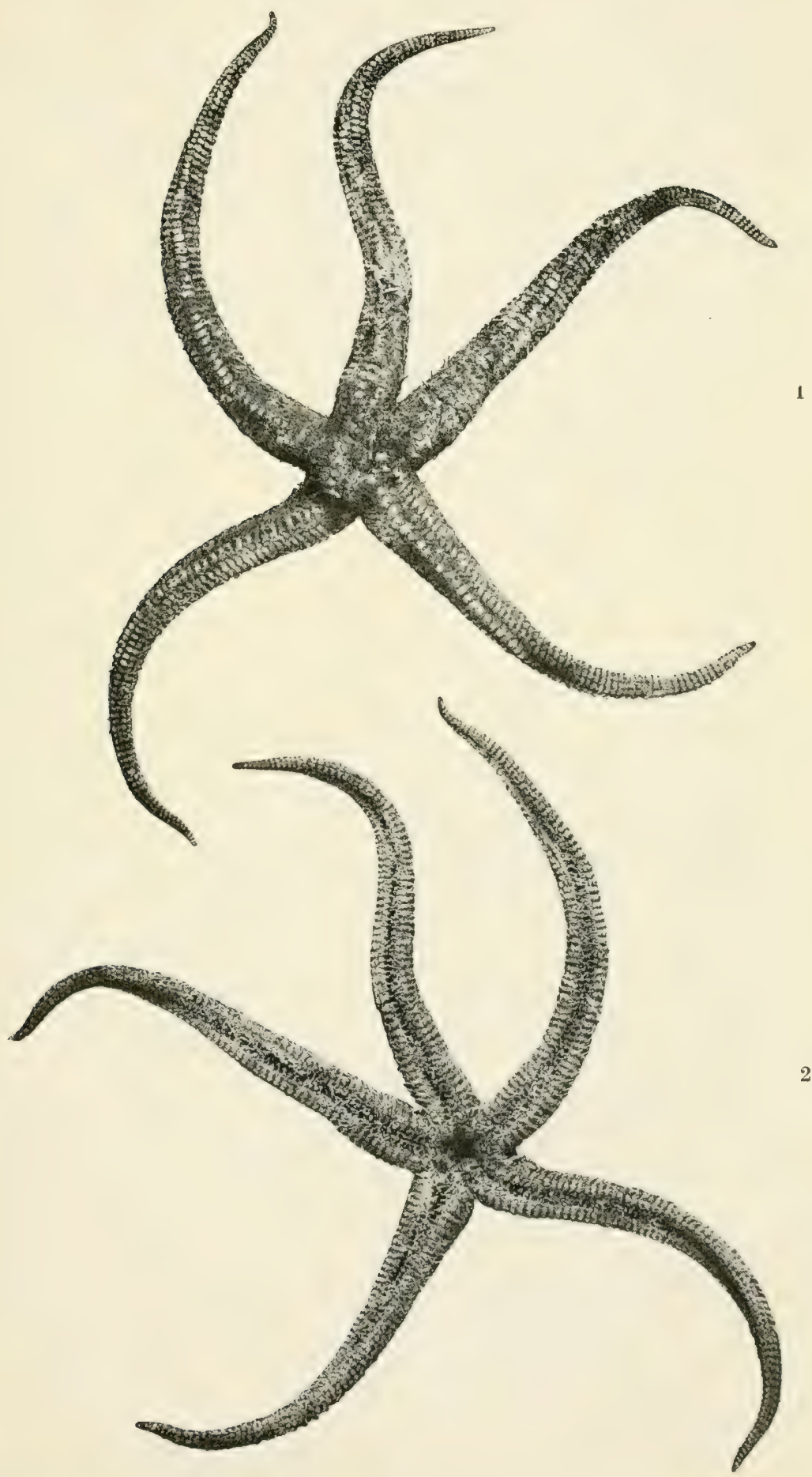

E. A. Briggs, Austr. Mus., photo. 



\section{EXPLANATION OF PLATE XXIX.}

Fig. 1.-Cosmasterias dyscrita, sp. nov. Photograph of the holotype from south of Gabo Island, Victoria, 200 fathoms. Abactinal view. Natural size.

Fis. 2.-Actinal view of same specimen as Fig. 1. 

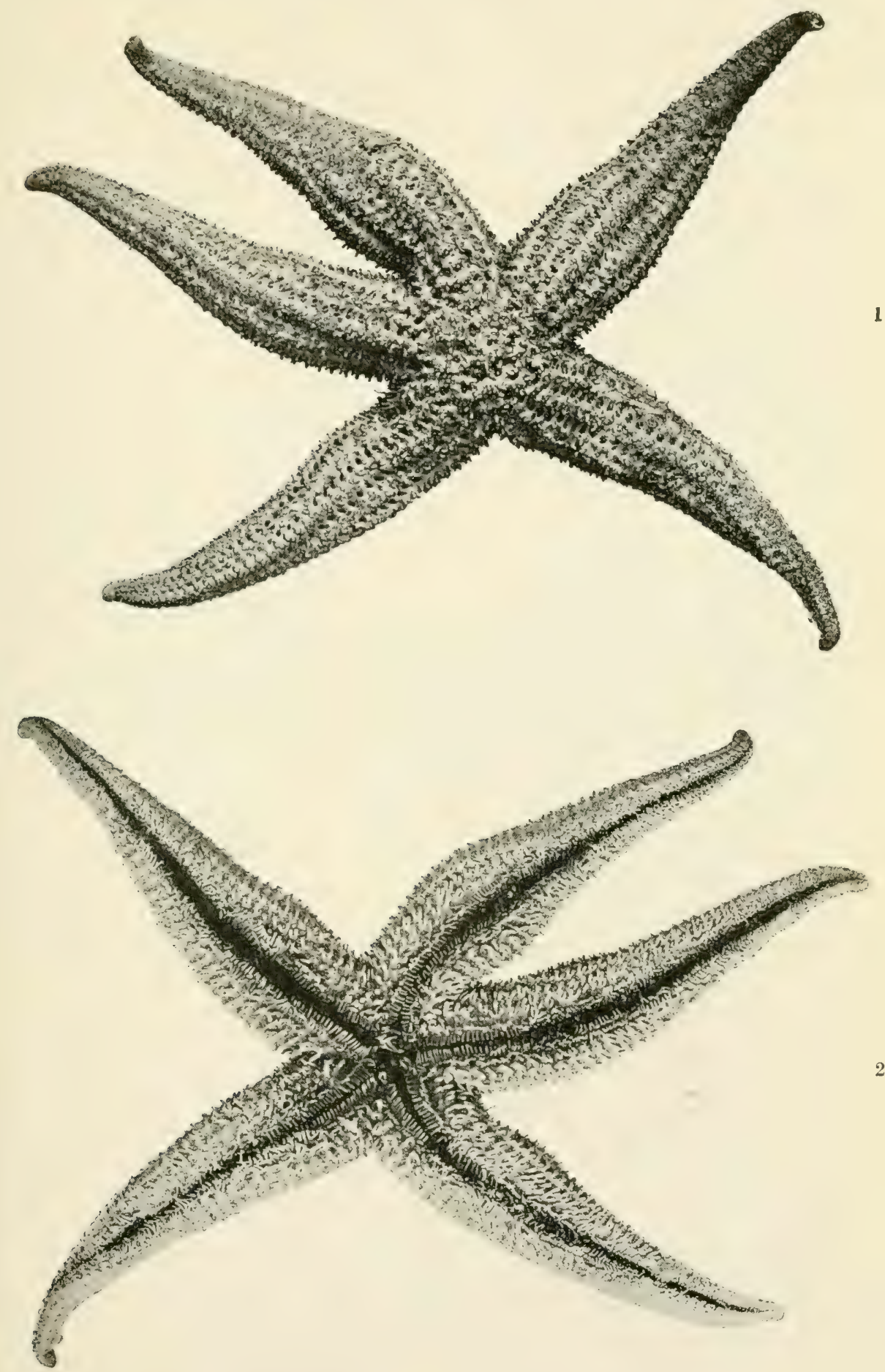

E. A. Briggs, Austr. Mus, photo. 


EXPLANATION OF PLATE XXX.

Fig. 1.-Coscinasterias dubia, H. L. Clark. Photograph of a specimen from the southern coast of South Australia. Abactinal view. One and one-half times natural size.

Fig. 2-Actinal view of same specimen as Fig. 1. 


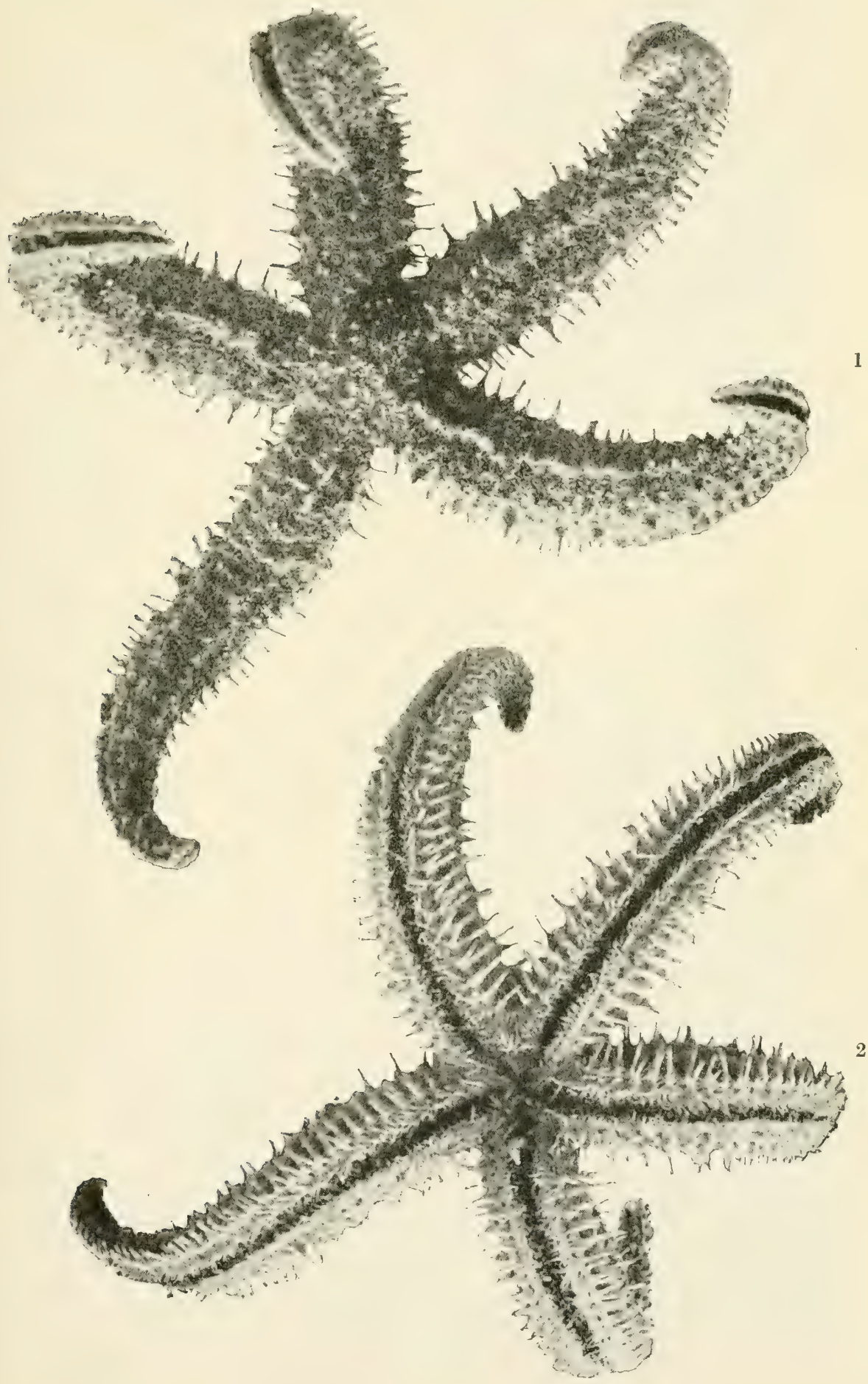

H. Barnes, Junr., Austr. Mus., photo. 




\section{EXPLANATION OF PLATE XXXI.}

Coscinasterias gemmifera, Perrier. Photograph of a specimen from Oyster Bay, 'Tasmania, 20-40 fathoms. Abactinal view. One-half natural size. 


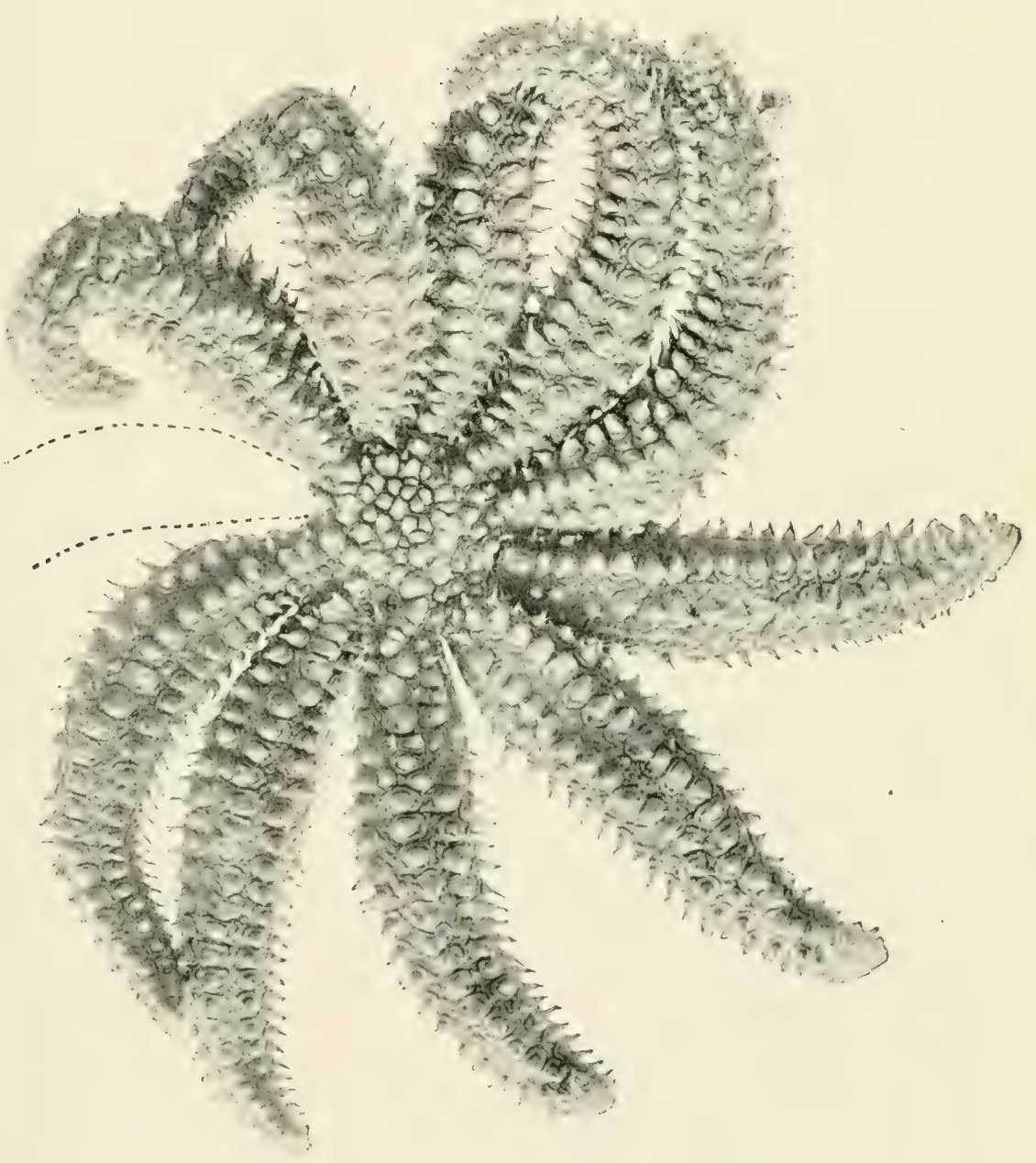

H. Barnes, Junr., Austr. Mus., photo. 

EXPLANATION OF PLATE XXXII.

Coscinasterias gemmifera, Perrier. Photograph of a specimen from Oyster Bay, Tasmania, 20-40 fathoms. Actinal view. One-half natural size. 
BIOL. RESULTS "ENDEAVOUR," VOL. IV.

Plate XXXII

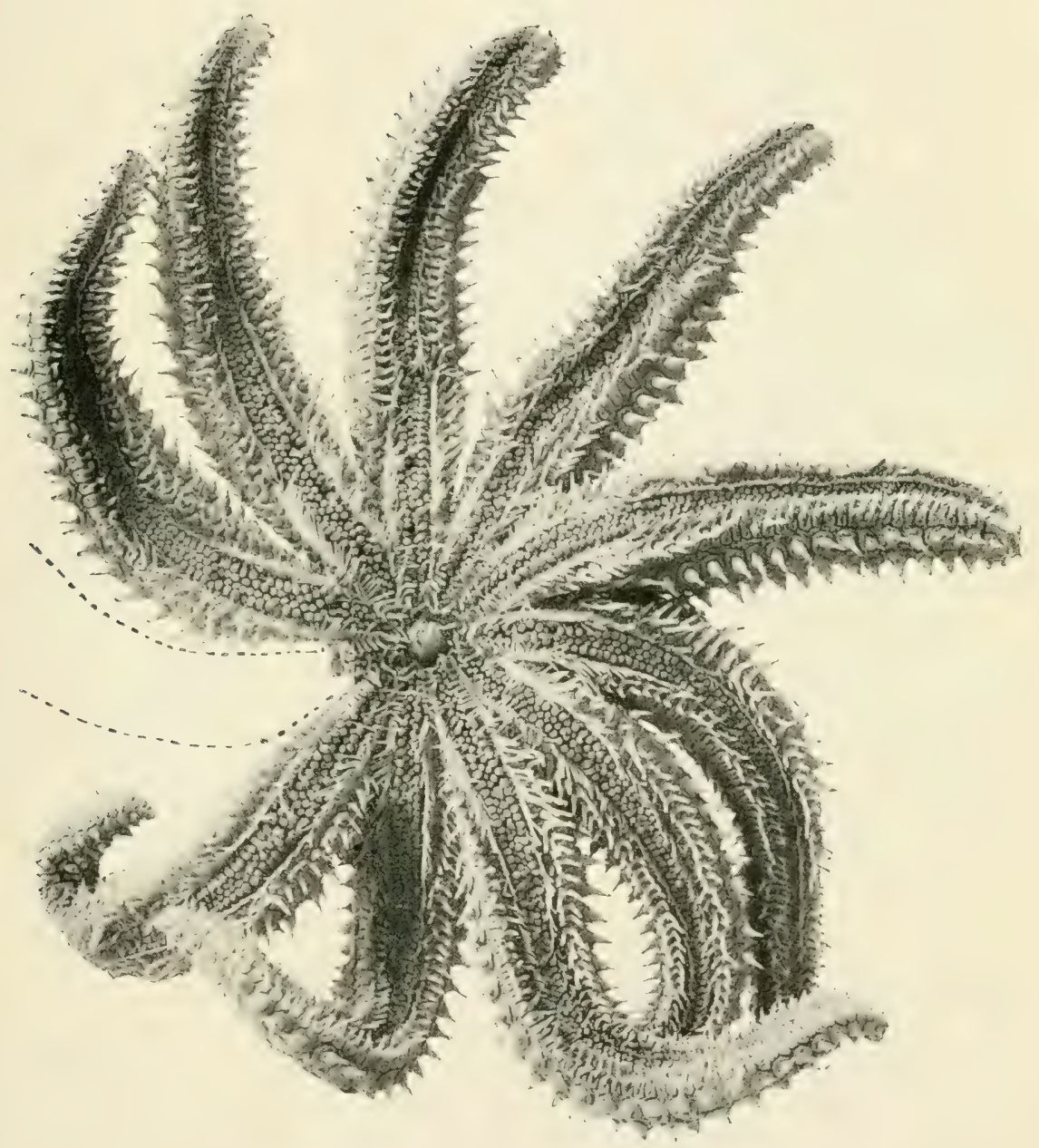

H. Barnes, Junr., Austr. Mus., photo. 




\section{EXPLANATION OF PLATE XXXIII.}

Fig. 1.-Ophiocreas phanerum, sp. nov. Photograph of the holotype from twenty miles off Cape Barren, Cape Barren Island, Tasmania, 70 fathoms. Abactinal view. Two-thirds natural size.

Fig. 2.-Actinal view of same specimen as Fig. 1. 


$$
\text { (89) }
$$






\section{EXPLANATION OF PLATE XXXIV.}

Fig. 1.-Astrodendrum pustulatum, sp. nov. Photograph of the holotype from east of Flinders Island, Bass Strait, 100-300 fathoms. Abactinal view. Natural size.

Fig. 2.-Actinal view of same specimen as Fig. 1. 

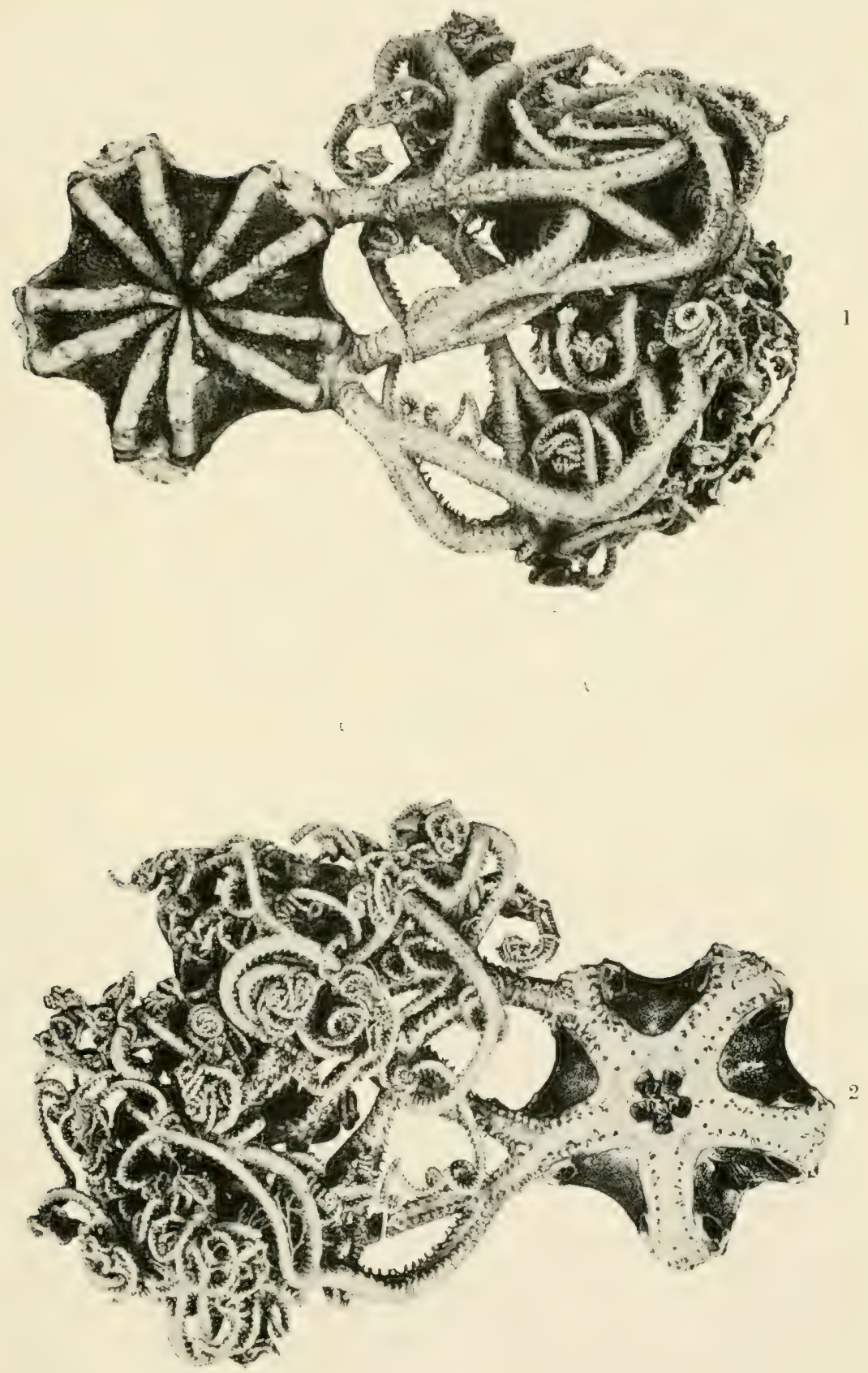

E. A. Brifas, Austr. Mus., photo. 


EXPLANATION OF PLATE XXXV.

Fig. 1.-Astrothamnus rugosus, sp. nov. Photograph of the holotype from east of Flinders Island, Bass Strait, 80-300 fathoms. Abactinal view. One and onethird times natural size.

Fig. 2.-Actinal view of same specimen as Fig. 1. 
BIOL. RESULTS " ENDEAVOUR," VoL. IV.

Plate XXXV.

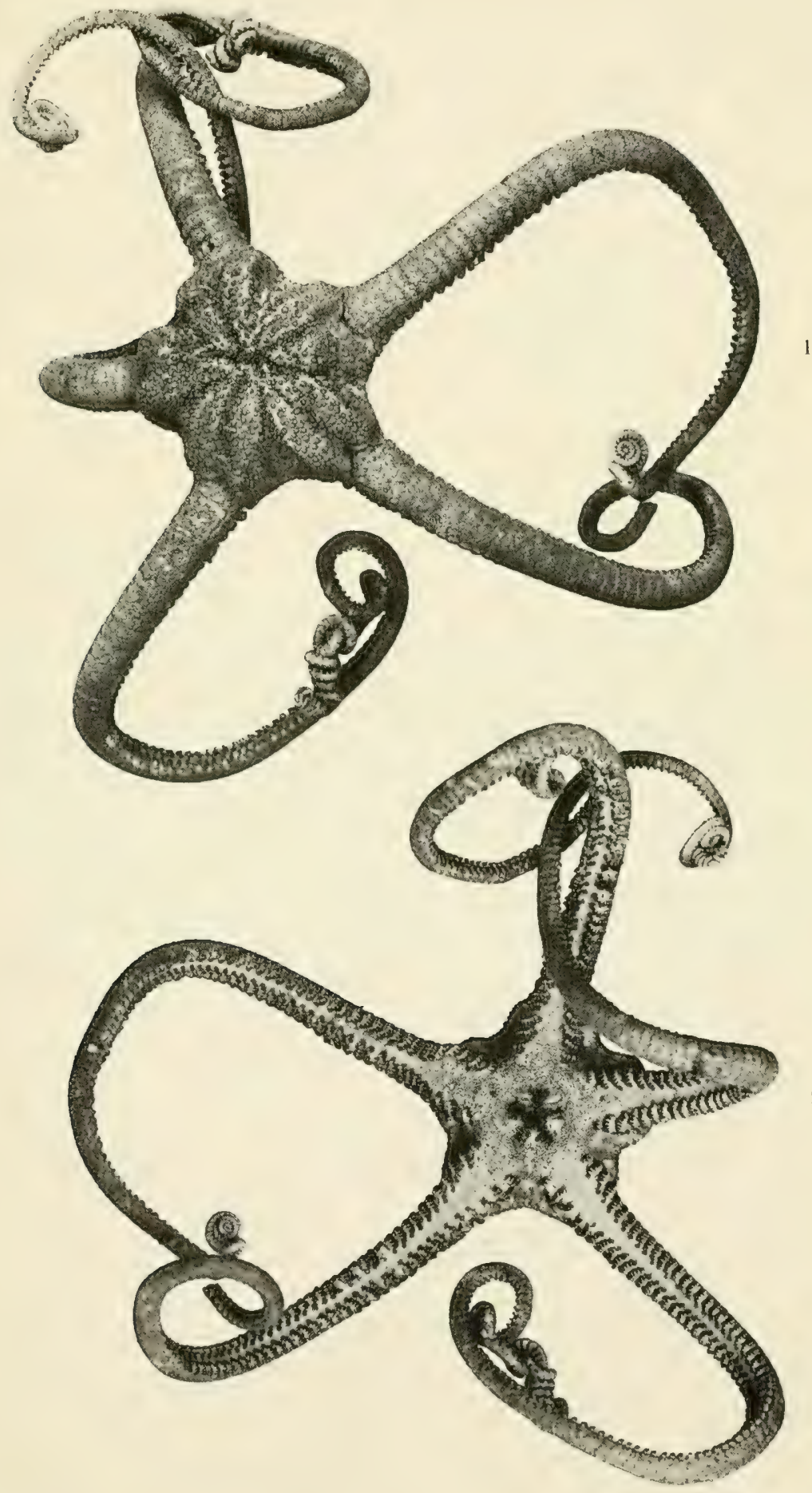

E. A. Briges, Austr. Mus., photo. 


EXPLANATION OF PLATE XXXVI.

Fig. 1.-Ophiuctis symbiota, sp. nov. Photograph of the holotype from east of Flinders Island, Bass Strait, 100300 fathoms. Abactinal view. Four times natural size.

Fig. 2.-Actinal view of same specimen as Fig. 1. 

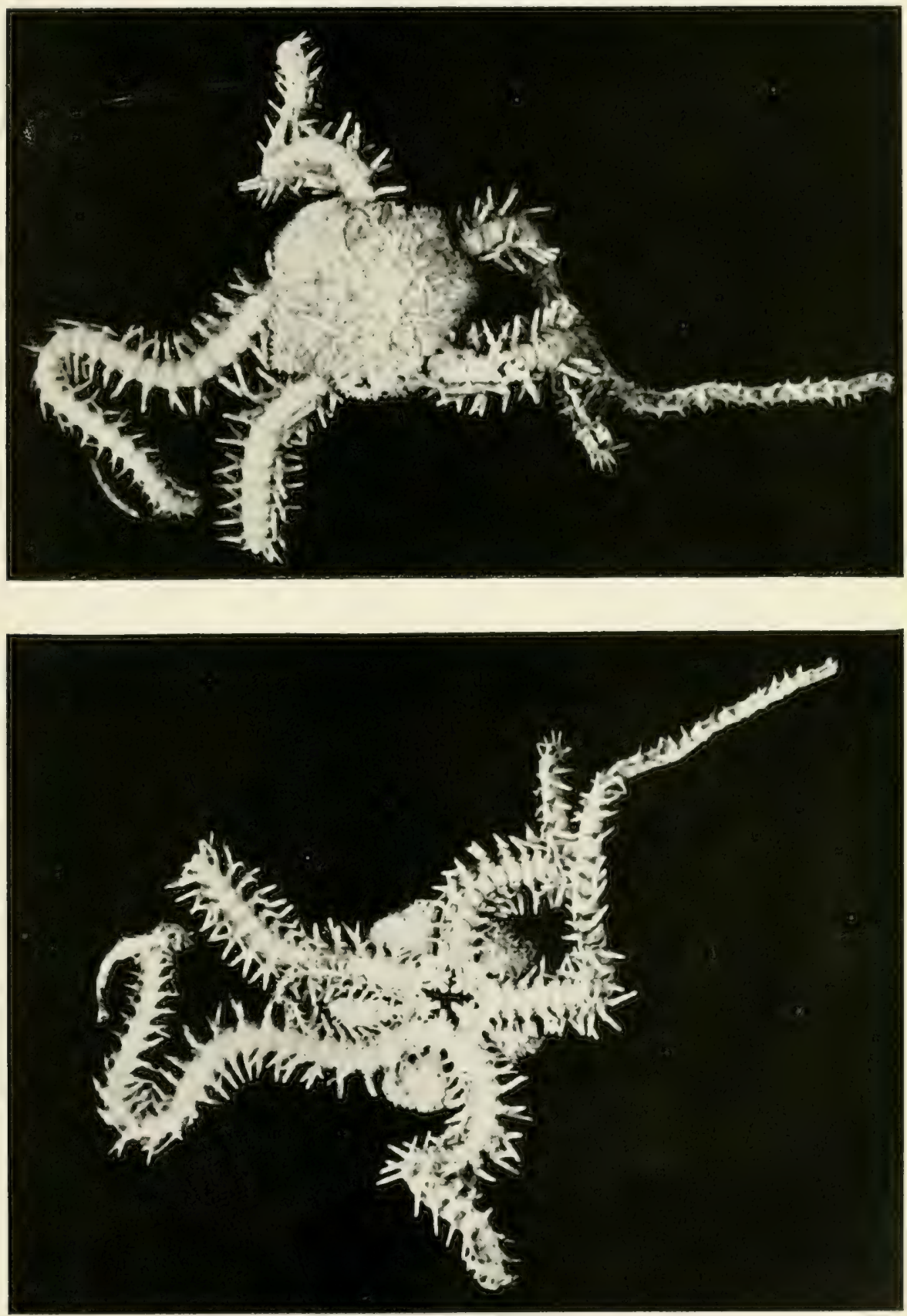

E A. Bricigs, Austr. Mus., photo. 




\section{EXPLANATION OF PLATE XXXVII.}

Fig. 1.-Amphiophiura collete, sp. nov. Photograph of the holotype from east of Babel Island, Bass Strait, 6080 fathoms. Abactinal view. One and five-eighth times natural size.

Fig. 2.-Actinal view of same specimen as Fig. 1. 
Bİl. RESUlts " ENDEATOUR," Vol. IT. Plate XXXYil.

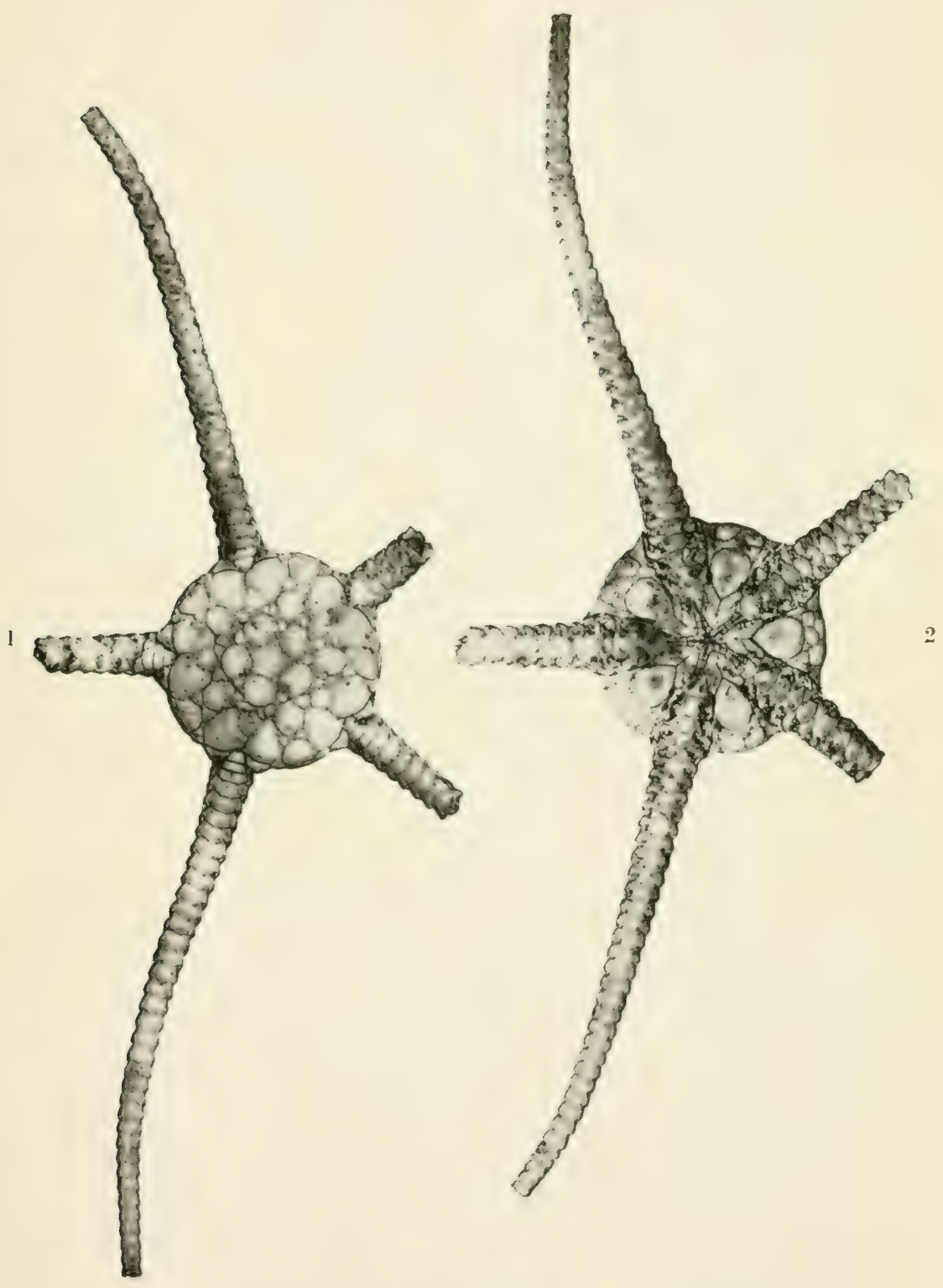

E. A. Brigas, Austr. Mus., photo. 



\section{EXPLANATION OF PLA'I'E XXXVIII.}

Fig. 1.-Cidaris conferta, sp. nov. Photograph of the holotype from the Eastern Slope, Bass Strait, $80-200$ fathoms. Abactinal view. 'Two-thirds natural size,

Fin. 2.-Actinal view of same specimen as Fig. I.

Fig. 3.- Side view of same specimen as Fig. 1.

Fin. 4.-Basal third of a large spine from the specimen shown in Fig. 1: Four times natural size. 
Bİ(L). RESULTS "ENDEATOUR," ToL, IV. Ptate XXXYIII.
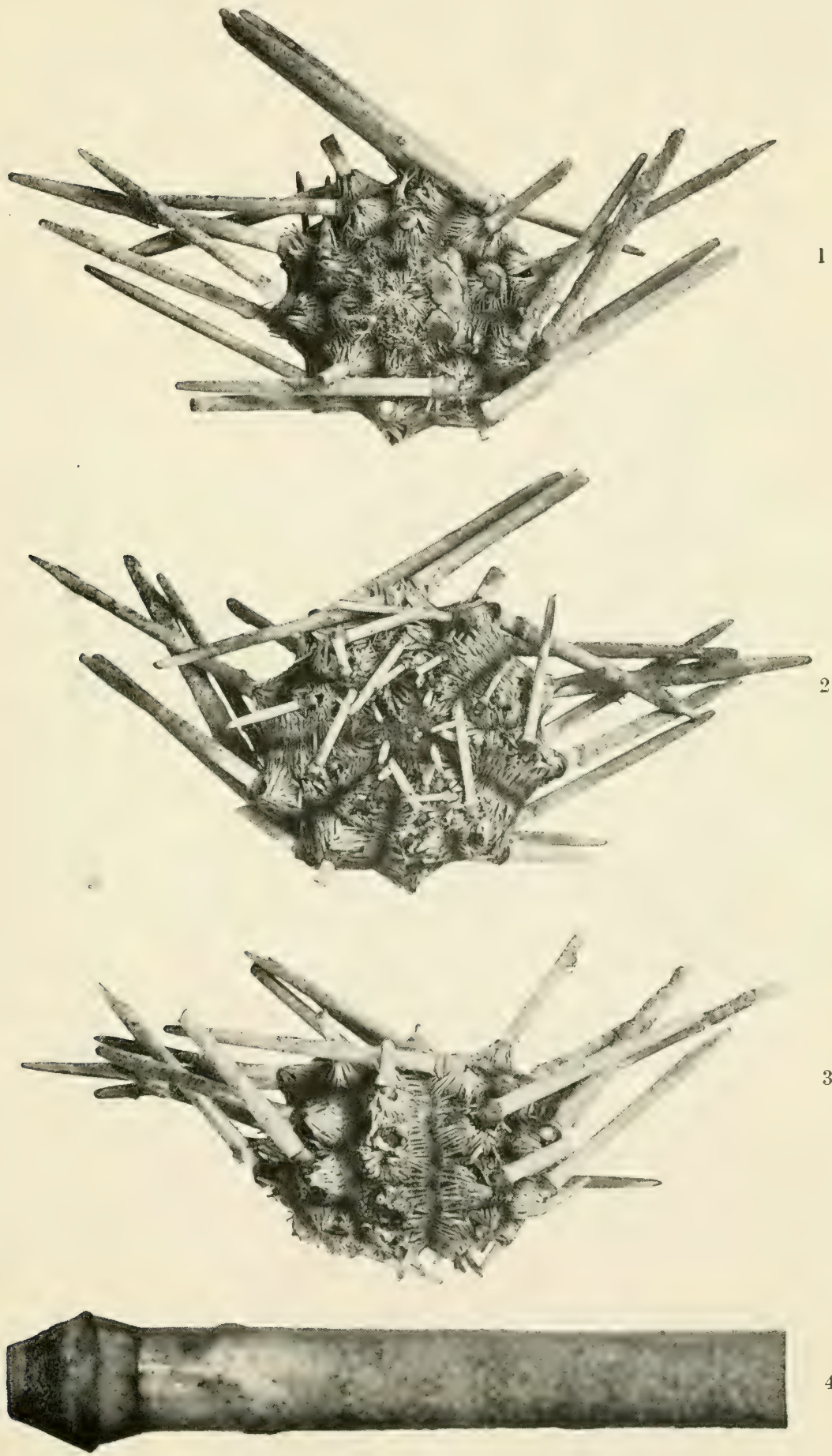

E. A. Briggs, Austr. Mus, photo. 


EXPLANATION OF PLA'TE XXXIX.

Echimus horridus, A. Agassiz. Photograph of an adult specimen from south of Gabo Island, Victoria, 100-250 fathoms. Side view. One and one-third times natural size. 


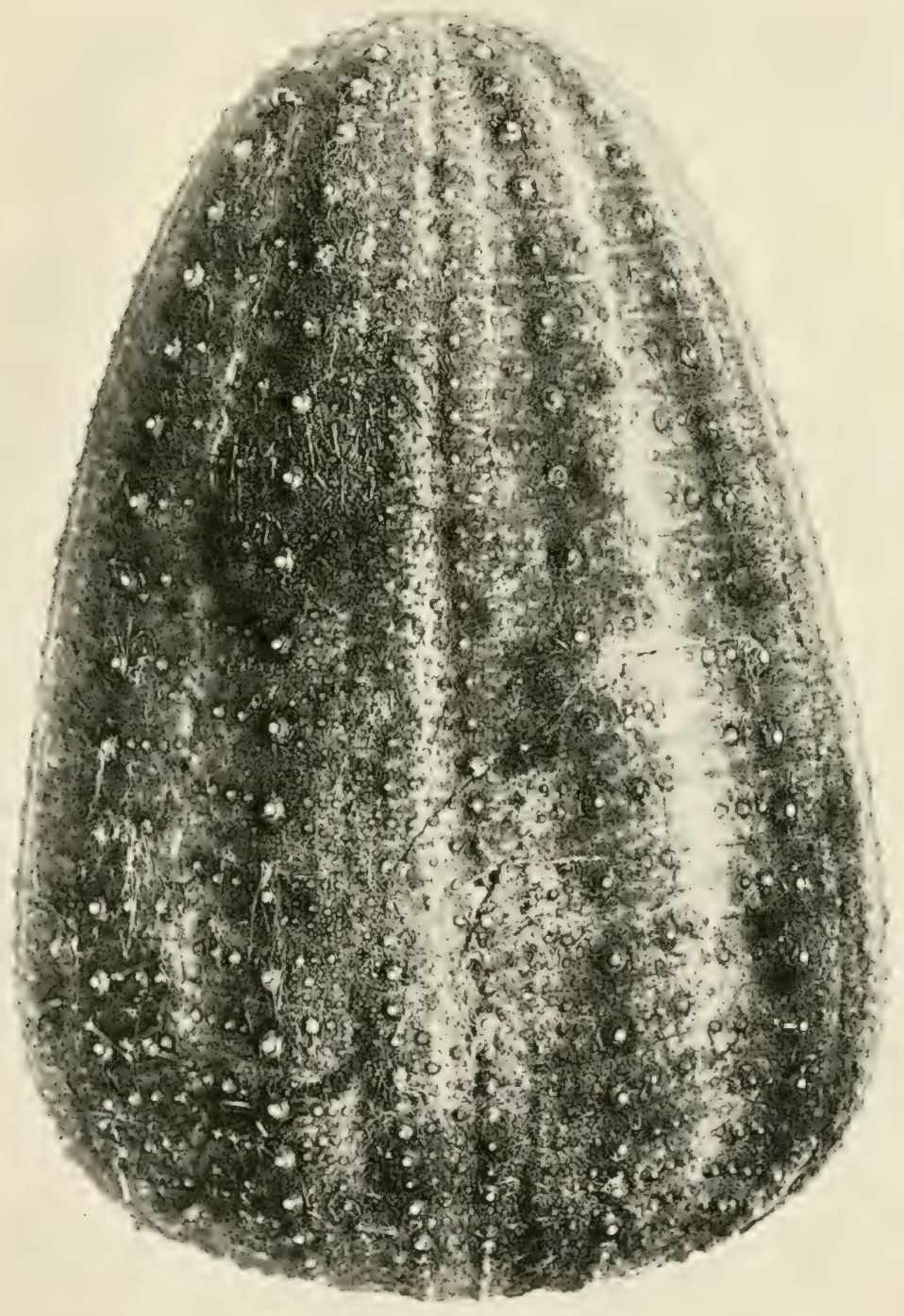

E. A. Briggs, Austr. Mus, photo. 



$$
\text { - }
$$




\section{EXPLANATION OF PLA'TE XL.}

Fig. 1.-Echinus horridus, A. Agassiz. Photograph of an adult specimen from south of Gabo Island, Victoria, 100-250 fathoms. Abactinal view. One and onefourth times natural size.

Fig. 2.-Actinal view of same specimen as Fig. 1. 

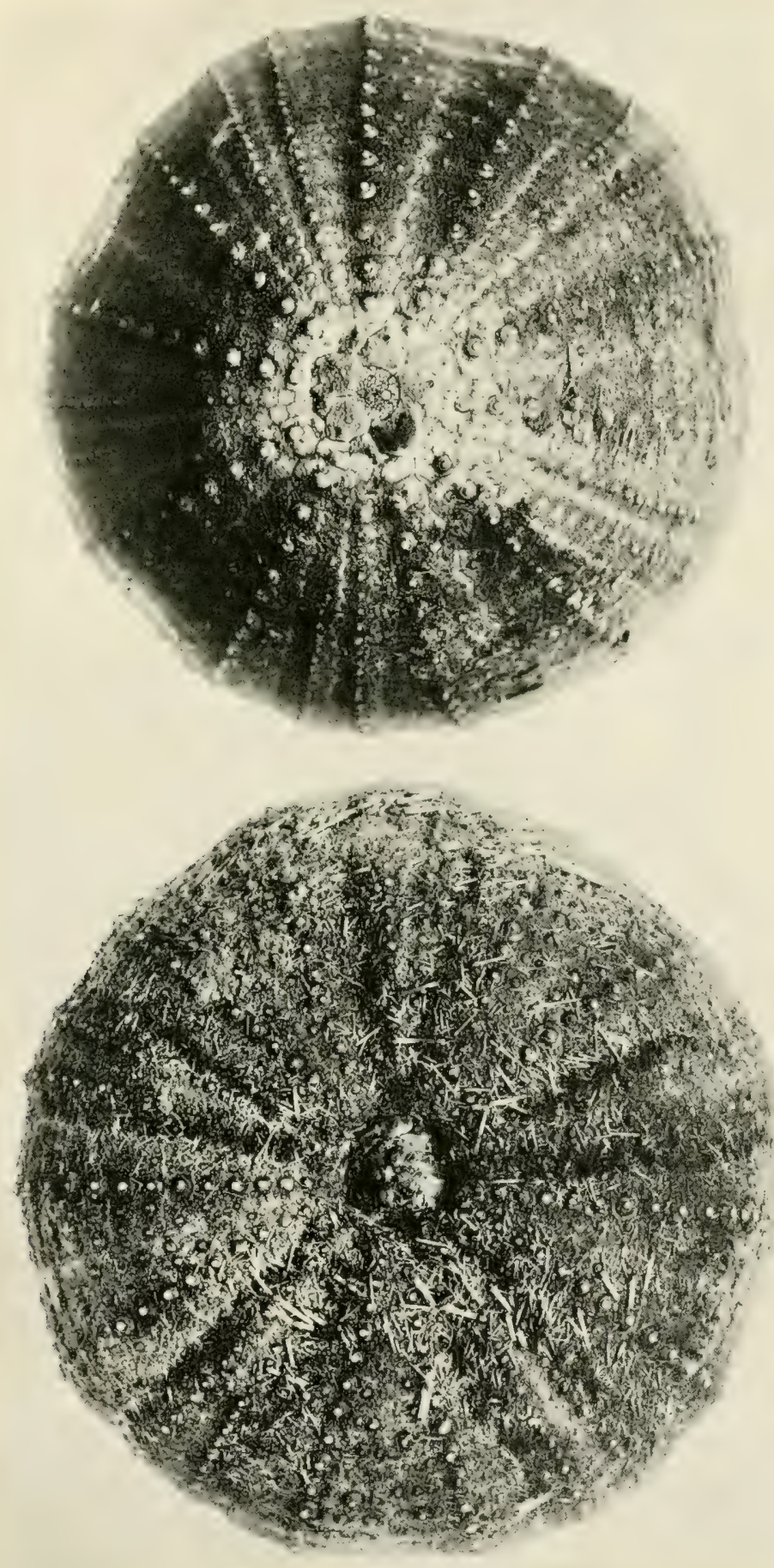

E. A. Briggs, Austr. Mus., photo. 



\section{EXPLANATION OF PLATE XLI.}

Fig. 1.-Parechinus notius, sp. nov. Photograph of the holotype from south of Gabo Island to south-east of Cape Everard, Victoria, 70-80 fathoms. Abactinal view. 'Twice natural size.

Fig. 2.-Actinal view of same specimen as Fig. 1.

Fig. 3.- Side view of same specimen as Fig. 1. 

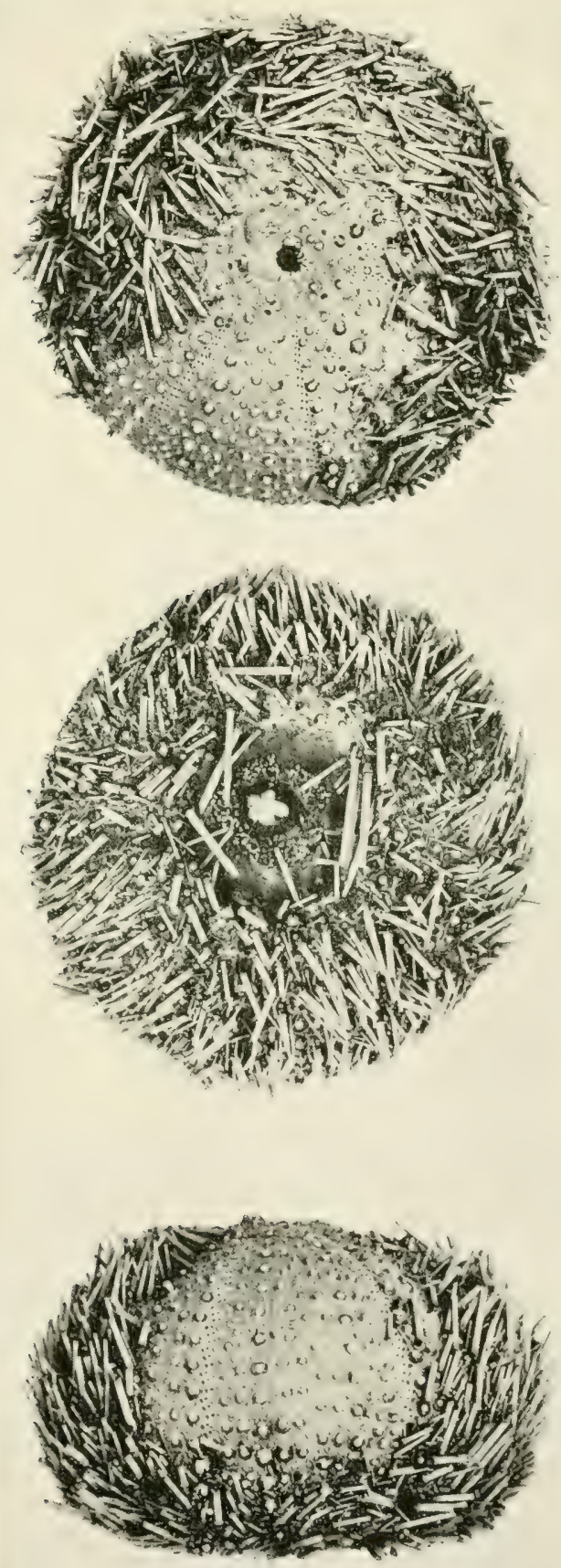




\section{EXPLANATION OF PLATE XLII.}

Fig. 1.-Salmacis oligopora, sp. nov. Photograph of the holotype from Oyster Bay, 'Tasmania, 20-40 fathoms. Abactinal view. Natural size.

Fig. 2.-Actinal view of same specimen as Fig. 1. 

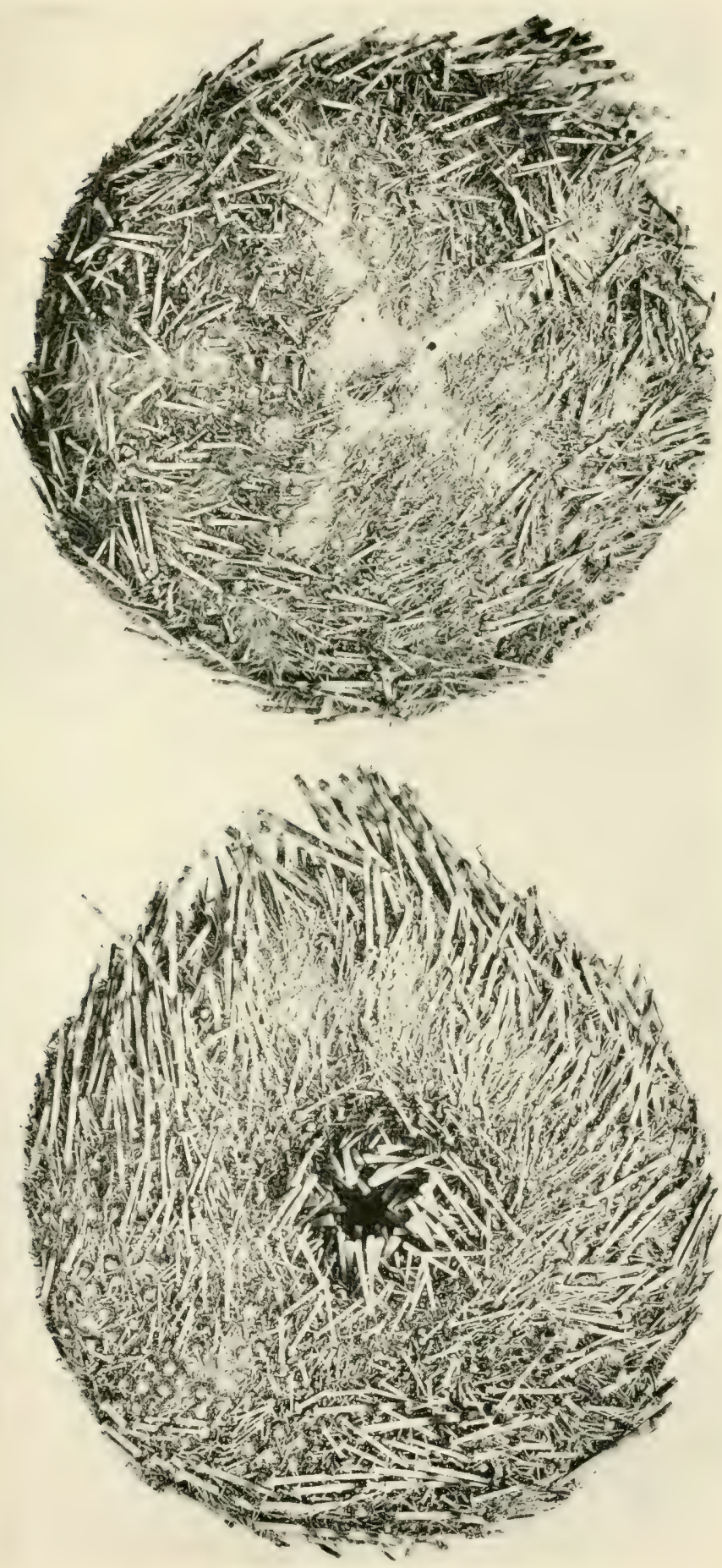

E. A. Briggs, Austr. Mus., photo. 




\section{EXPLANATION OF PLATE XLIII.}

Fig. 1.-Coelopleurus australis, sp. nov. Photograph of the holotype from the Eastern Slope, Bass Strait, 60-112 fathoms. Side view. Natural size.

Fig. 2.-Salmacis oligopora, sp. nov. Photograph of the holotype from Oyster Bay, Tasmania, 20-40 fathoms. Side view. Natural size. 
BIOL. RESULTS " ENDEAVOUR," VoL. IV.

Plate Xliti。

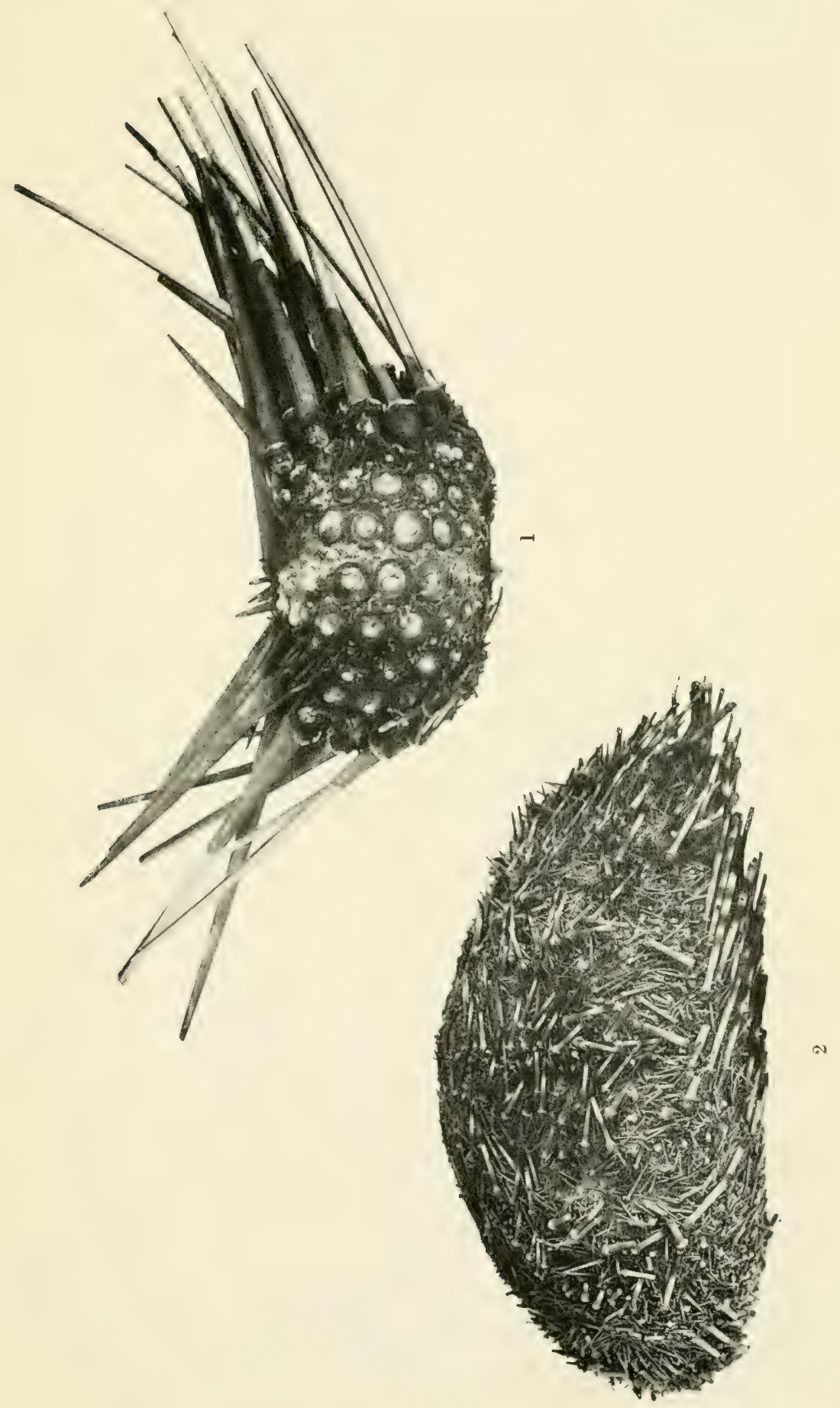

E. A. Briggs, Austr. Mus., photo. 




\section{EXPLANATION OF PLATE XLIV.}

Fig. 1.-Maretia peloria, sp. nov. Photograph of the paratype from twenty-six miles south-west of Cape Everard, Victoria. Abactinal view. Natural size.

Fig. 2.-Side view of same specimen as Fig. 1.

Fig. 3.-Actinal view of same specimen as Fig. 1. 

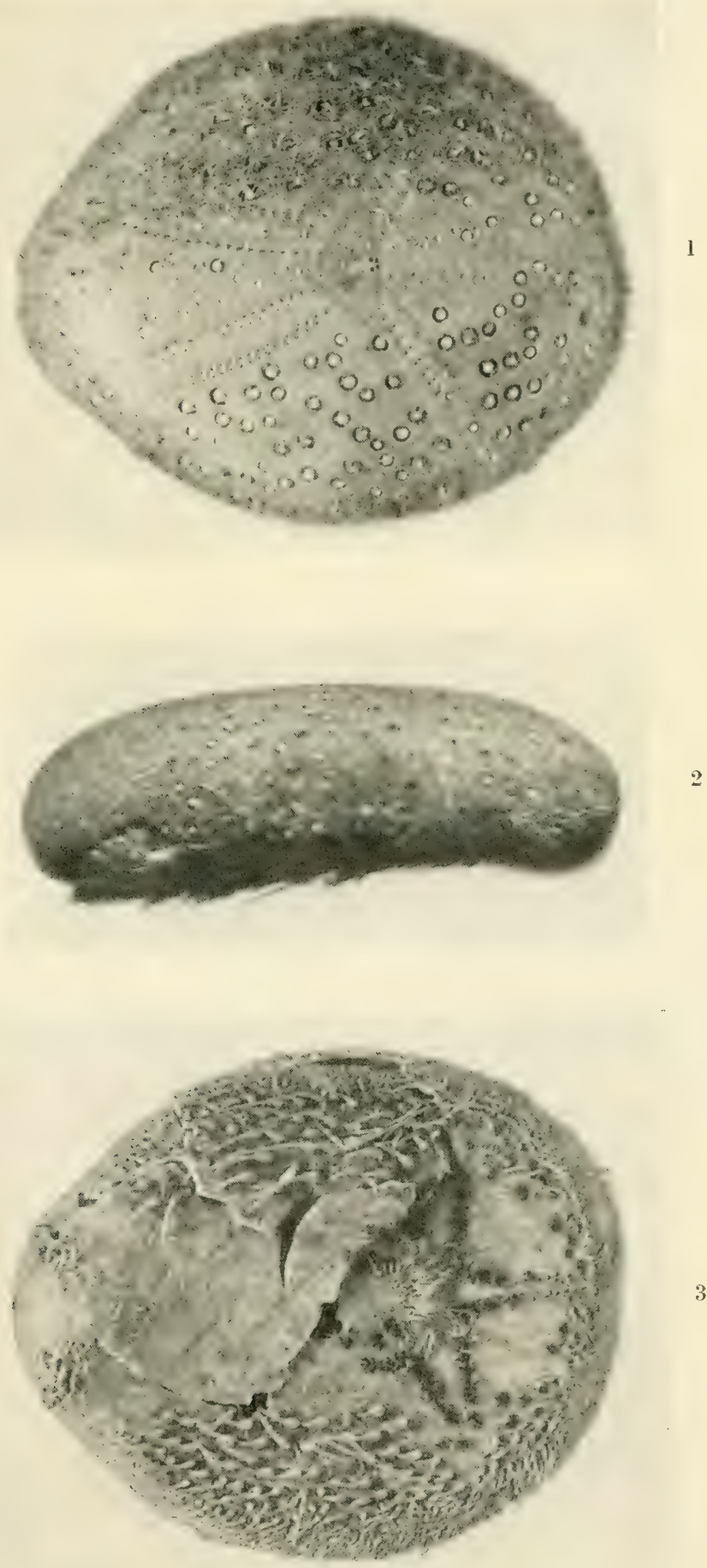
II 



